$$
\begin{gathered}
\text { UNIVERSIDADE DE SÃO PAULO } \\
\text { INSTITUTO DE FÍSICA } \\
\text { INSTITUTO DE QUIIMICA } \\
\text { INSTITUTO DE BIOLOGIA } \\
\text { FACULDADE DE EDUCAÇÃO }
\end{gathered}
$$

BEATRIZ VIVIAN SCHNEIDER-FELICIO

Formação de conceitos da termoquímica em meio a relações CTSA e questões sociocientíficas:

contribuições da Teoria da Atividade Histórico-Cultural

São Paulo

2018 
Beatriz Vivian Schneider-Felicio

\title{
Formação de conceitos da termoquímica em meio a relações CTSA e questões sociocientíficas: contribuições da Teoria da Atividade Histórico-Cultural
}

\author{
Versão Corrigida \\ (Versão original encontra-se na unidade que aloja o \\ Programa de Pós-Graduação)
}

Tese de Doutorado apresentada ao Instituto de Química, Instituto de Física, Instituto de Biociências e à Faculdade de Educação da Universidade de São Paulo para a obtenção do título de Doutora em Ensino de Ciências.

Área de Concentração: Ensino de Química

Orientador: Prof. Dr. Mauricio dos Santos Matos 
Autorizo a reprodução e divulgação total ou parcial deste trabalho, por qualquer meio convencional ou eletrônico, para fins de estudo e pesquisa, desde que citada a fonte.

\section{FICHA CATALOGRÁFICA}

\section{Preparada pelo Serviço de Biblioteca e Informação} do Instituto de Física da Universidade de São Paulo

Schneider-Felicio, Beatriz Vivian

Formação de conceitos da termoquímica em meio a relações CTSA e questões sociocientíficas: contribuições da teoria da atividade histórico-cultural. São Paulo, 2018.

Tese (Doutorado) - Universidade de São Paulo. Faculdade de Educação, Instituto de Física, Instituto de Química e Instituto de Biociências.

Orientador: Prof. Dr. Mauricio dos Santos Matos

Área de Concentração: Ensino de Química

Unitermos: 1. Química - Estudo e ensino; 2. Ensino e aprendizagem; 3. Impactos socioambientais; 4. Formação do indivíduo 
Ao meu esposo, com amor, admiração e gratidão por sua compreensão, atenção, carinho e incansável apoio ao longo da elaboração deste trabalho.

Aos meus pais, com amor e admiração, pois sempre se privavam de muitas coisas para apoiar minha caminhada ao longo da vida. 


\section{Agradecimentos}

A Deus, por estar comigo em cada sinapse.

A Romulo, pela paciência, carinho e amor.

A Naemi e Osmar, pela educação e exemplo que recebi.

A William, pelo carinho e irmandade.

Ao professor Mauricio, por compartilhar seus conhecimentos, me orientar e me tranquilizar durante a caminhada.

Ao professor Danilo, por acreditar neste trabalho antes mesmo do projeto.

Aos professores Cristiano e Ori, pelo auxílio com a teoria da atividade e carinho.

Ao Grupo CIMEAC, pela intensa aprendizagem que me transforma como professora e pessoa.

Ao Grupo GEPIC, pelo apoio e discussões do projeto.

Ao Grupo ECCo, pelo apoio nas discussões teóricas.

Aos professores Ori, Elaine, Maria do Carmo e Joana, pelas disciplinas marcantes e decisivas para este trabalho.

A Ulisses, Renato, Gabriel e André, pelo apoio na aplicação das aulas. .

A Osmar, Rogener e Erlon, pelos microfones e câmeras cedidos.

A Raquel, Roberta, Valéria, Luiz Olímpio e Nicolas pela convivência e carinho.

Aos amigos e amigas que me deram alegria! 
E nós estamos ainda no processo de aprender como fazer democracia. E a luta por ela passa pela luta contra todo tipo de autoritarismo

(Freire, 2000, p. 136). 


\section{RESUMO}

SCHNEIDER-FELICIO, Beatriz Vivian. Formação de conceitos da termoquímica em meio a relações CTSA e questões sociocientíficas: contribuições da Teoria da Atividade Histórico-Cultural. 2018. $274 \mathrm{f}$. (Doutorado em Ensino de Ciências, modalidade Ensino de Química) - Instituto de Física, Instituto de Química, Instituto de Biologia e Faculdade de Educação, São Paulo, Universidade de São Paulo, São Paulo, 2018.

Este trabalho incide sobre um problema antigo e ainda atual observado na educação escolar: a ruptura entre os conteúdos disciplinares ensinados na escola e a vida do aluno fora dela. O aluno é apartado de uma forma de conhecimento que o torne consciente de sua realidade como sujeito ativo de sua história e da história humana. Esta separação é refletida na Educação em Ciências, sendo muitas as propostas que buscam proporcionar ao aluno um entendimento crítico do conhecimento científico, tais como a perspectiva CTSA (ciência, tecnologia, sociedade e ambiente), que aponta em direção à inclusão de questões sociais da realidade do aluno nas aulas de ciências. A motivação inicial deste trabalho baseou-se na busca de uma fundamentação teórica que pudesse nos ajudar a compreender o processo humano de apropriação do conhecimento, e, a partir desta compreensão, organizar uma aula de química que pudesse superar a referida ruptura. Nessa direção, assumimos como fundamentação teórica a Teoria da Atividade Histórico-Cultural, estabelecendo, como objetivo da tese, analisar o processo de formação de conceitos da termoquímica em meio a questões do contexto histórico-social do aluno mediadas por relações CTSA e por questões sociocientíficas. A pesquisa centrou seu foco no processo de aplicação de uma atividade de ensino, elaborada e aplicada em um curso pré-vestibular do movimento de Educação Popular da cidade de Ribeirão Preto, localizada no estado de São Paulo. A atividade de ensino foi desenvolvida numa perspectiva socioambiental crítica em relação à produção e ao uso de combustíveis pelo homem, sendo registradas todas as falas dos alunos durante as atividades, por meio do uso de câmeras dispostas estrategicamente para a coleta do áudio durante as atividades, como também desenvolvidas produções textuais, analisadas a partir de alguns referenciais teórico-metodológicos da Teoria da Atividade HistóricoCultural. Como resultado da análise dos dados, observou-se que o processo de formação dos conceitos da termoquímica em meio ao contexto histórico-social do aluno é determinado pela estrutura e pelo movimento da atividade, o qual depende da preparação e mediação do professor, já que tanto a concretização e sistematização, como as generalizações, as apropriações e significações configuram-se como processos mediados. Observou-se, também, o papel relevante da mediação do professor em considerar os conceitos espontâneos do aluno como forma de proporcionar concretude aos conceitos científicos. Tanto nas interações de sala de aula quanto nos textos analisados, identificouse que a apropriação de conceitos ocorreu por meio da união entre uma necessidade humana real e o conceito químico. Os conceitos científicos da termodinâmica, cujas formas de ação (operações) fundamentais não são executadas pelo aluno, mostraram ter desenvolvimento reduzido, enquanto os aspectos CTSA e as QSC, coordenados pela estrutura e movimento da atividade de ensino-aprendizagem, mostraram servir como instrumentos úteis para a interação do conhecimento químico com o contexto histórico-social do aluno. 
Palavras-chave: educação em ciências, ensino de química, formação de conceitos, teoria histórico-cultural, teoria da atividade. 
SCHNEIDER-FELICIO, Beatriz Vivian. Formation of thermochemistry concepts in the middle of STSE relations and socioscientific issues: contributions of the Theory of Historical-Cultural Activity. 2018. 274f. (PhD in Science Teaching, Teaching of Chemistry) - Institute of Physics, Institute of Chemistry, Institute of Biology and Faculty of Education, São Paulo, University of São Paulo, São Paulo, 2018.

This work focuses on an old and still current problem observed in school education: the rupture between the disciplinary contents taught in school and the life of the student outside it. The student is deprived of a knowledge form that makes him aware of his reality as an active author of his history and of human history. This problem is reflected in Science Education being many the proposals that seek to provide the student a critical understanding of scientific knowledge. Among them we share intentions with those that aims to include social issues of the student's reality in science classes, such as the CTSA perspective (relations between science, technology, society and environment). The initial motivation for this work is set in the search for a theoretical foundation that can help us to understand how the human process of knowledge appropriation happens, and, from this understanding, to organize a chemistry class that surpasses the said rupture. In this direction, we assume this theoretical foundation in the Historical-Cultural Activity Theory establishing, as the thesis objective, to analyze the process of thermochemistry concepts formation in the middle of questions of the student historical and social context mediated by STSE relations and socio-scientific issues. The research focused on the process of applying a teaching activity, elaborated and applied in a prevestibular course of Popular Education movement of Ribeirão Preto city, located in the São Paulo state. The teaching activity was developed from a critical socio-environmental perspective in relation to the production and use of fuels by man, and all the speeches of the students were recorded during the activities, through the use of strategically arranged cameras to collect the audio during the activities, as well as developed textual productions, analyzed from some theoretical-methodological references of the Theory of Historical-Cultural Activity. The analysis results shows that the process of thermochemistry concepts formation in the student's historical-social context is determined by the activity structure and movement, which depends on the activity preparation and mediation by the teacher. The concretization and systematization, the generalizations, the appropriations and significations are mediated processes. It is important to consider, in the teacher's mediation, the spontaneous concepts of the student to provide concreteness to the scientific concepts. In both classroom and text interactions, the appropriation of concepts occurs through the union of a real human need with a chemical concept. The concept whose fundamental forms of action (operations) are not executed by the student has a reduced development. The CTSA aspects and socioscientific issues, coordinated by the structure and movement of the teaching-learning activity, serve as instruments to provide the interaction between the chemical knowledge and the student socio-historical context.

Key words: science education, chemistry teaching, concept formation, historical-cultural theory, activity theory 


\section{Lista de siglas}

\begin{tabular}{|c|c|}
\hline$A C$ & Alfabetização Científica \\
\hline AOE & Atividade Orientadora de Ensino \\
\hline ACT & Alfabetização Científica e Tecnológica \\
\hline $\mathrm{C} \& \mathrm{~T}$ & Ciência e Tecnologia \\
\hline CIMEAC & Centro de Investigações de Metodologias Alternativas Conexão \\
\hline CNE & Conselho Nacional de Educação \\
\hline CTS & Ciência, Tecnologia e Sociedade; \\
\hline CTSA & Ciência, Tecnologia, Sociedade e Ambiente; \\
\hline DDT & dicloro-difenil-tricloroetano \\
\hline EA & Educação Ambiental \\
\hline EC & Ensino de Ciências \\
\hline EP & Educação Popular \\
\hline ERIC & Education Resources Information Center \\
\hline MEC & Ministério da Educação \\
\hline NOS & Nature of Science (Natureza da Ciência) \\
\hline ONG & Organização não governamental \\
\hline $\mathrm{PCN}$ & Parâmetros Curriculares Nacionais \\
\hline PLACTS & $\begin{array}{l}\text { Pensamento Latino Americano de Ciência, Tecnologia e } \\
\text { Sociedade }\end{array}$ \\
\hline QSC & Questões sociocientíficas \\
\hline SAF & Sistema Agro Florestal ou Sistema de Agro Floresta \\
\hline SAt & Sequência de Atividades \\
\hline $\mathrm{T}$ & Tecnologias da Informação e Comunicação \\
\hline
\end{tabular}




\section{Apresentação}

Nesta apresentação gostaria de preparar o leitor quanto a possíveis expectativas relacionadas ao título da pesquisa e compartilhar brevemente sua trajetória.

Supomos que um leitor interessado nas propostas CTS/CTSA e/ou QSC pode vir a esperar desenvoltura ou fidelidade aos mais rescentes materiais e métodos de ensino propostos pelos mesmos. Um leitor da área da Educação em Química pode vir a esperar o máximo desenvolvimento dos conceitos químicos escolares pelos alunos. Já um leitor interessado na Teoria da Atividade pode esperar o uso da totalidade desta teoria ou a fidelização metodológica específica em algum de seus autores mais recentes.

No entanto, adianto que o que fazemos aqui é uma primeira tentativa de identificação de convergências que relacionem as principais propostas de ensino que acompanharam minha trajetória de pesquisa em Ensino de Ciências com aspectos centrais da fundamentação teórica da Teoria da Atividade Histórico - Cultural. Este primeiro movimento do trabalho não intenciona esgotar a literatura na caracterização das propostas CTS, Educação Ambiental, Alfabetização Científica, Natureza da Ciência e Educação Popular, mas mostrar pontos convergentes que corroborem na superação da ruptura entre a educação escolar e a realidade histórico-cultural do aluno.

$\mathrm{Na}$ busca destas convergências, que guarda esforços teóricos e práticos, deparei-me com um universo de pesquisa rico e complexo, com uma quantidade de variáveis que até então não tinha me deparado. Por isso, posso dizer figurativamente que este mesmo universo se deparou com uma pesquisadora limitada, principalmente no sentido de ainda carregar uma formação acostumada a isolar variáveis para fazer análises, e amarrada ao ensino tradicional acrítico, o qual busca superar. Superar não no sentido de negar, mas de expandir, complexificar.

Assim, o que o leitor pode esperar é uma interpretação, dentro dos limites e limitações deste trabalho, sobre os indícios de formação de conceitos químicos em meio a discussões sociais reais, na qual o tema de uma aula pode gerar discussões valorativas e paralelas aos conceitos químicos, sobre aspectos sociais, os quais consideramos tão importantes quanto os conceitos 
químicos. Não para o recorte de nossa análise, mas para a formação dos alunos e professores envolvidos.

A origem deste trabalho surge da insatisfação com a própria prática de sala de aula como professora de Química do Ensino Médio, aliada a resultados e anseios da pesquisa de mestrado, concernente à promoção da Educação Ambiental crítica em aulas de química, o que, no mestrado, já se relacionava teoricamente à proposta CTSA, a qual, por sua vez, se relaciona à proposta da Alfabetização Científica e da Natureza da Ciência, dentre outras que, devido aos limites deste trabalho, não foram contempladas na discussão.

Além destas propostas de abordagem de ensino, a partir de 2013 tive a oportunidade e experiência transformadora de lecionar em um projeto de Educação Popular, o qual, atendia alunos sem condições financeiras para onerar um curso pré-vestibular regular, em sua maioria, egressos ou em curso do Ensino Médio da rede Pública, trazendo à tona questões e realidades de privação ao acesso à educação de qualidade. Esta realidade se unia aos estudos, sobre autores da Educação Popular (EP), realizados pelos professores do projeto. Dentre autores da EP se destacou para mim Paulo Freire, o qual já era citado na literatura acadêmica por autores das propostas da Educação Ambiental (EA), CTS/CTSA, Alfabetização Científica, o que trazia mais convergências entre as propostas de ensino, em relação aos ideais de educação.

Neste momento, gostaria de esclarecer ao leitor que o presente trabalho traz os ideais freireanos de educação como um dos pontos de convergência entre as concepções das propostas de ensino, que vê na superação do ensino tradicional acrítico um meio para a superação de desigualdades e injustiças sociais. Portanto, Paulo Freire não compõem nosso refencial teóricometodológico, apesar de apresentar convergências teóricas com o mesmo. 0 referencial teórico-metodológico do presente trabalho toma por base a Teoria da Atividade Histórico-Cultural.

Retomando as origens da pesquisa, a proposta metodológica diferenciada já existente no projeto de Educação Popular torna o trabalho com os alunos um espaço para a busca do uso das perspectivas da EA e CTSA na prática de ensino-aprendizagem de química, e além destas, as questões 
sociocientíficas (QSC), as quais me foram apresentadas pelo professor Danilo Kato, que já trabalhava com esta perspectiva.

E foi a partir do trabalho com os alunos e professores do projeto, da busca pela superação do ensino tradicional acrítico, não só minha, mas de todo grupo de trabalho, que a questão de pesquisa, sobre como se dá a formação dos conceitos químicos escolares em meio a análises de questões sociais reais trazidas pelas relações CTSA e QSC, foi se delineando como projeto de pesquisa do doutorado.

Ao longo dos estudos sobre as propostas CTSA e QSC, percebemos que a literatura das mesmas não dariam conta de respaldar a análise da formação dos conceitos químicos, e é aí que entram, por meio de disciplinas na pós-graduação e de contatos com outros grupos de pesquisa, as contribuições da Teoria da Atividade Histórico-Cultural, a qual nos respaldou principalmente a compreensão sobre como se dá o processo humano da apropriação do conhecimento, de forma que suas contribuições para a pesquisa vão para além da análise da formação de conceitos químicos - o que pretendemos mostrar no desenrolar do trabalho.

Uma destas contribuições foi entender a aula aqui proposta, cujas interações discursivas foram analisadas, como uma atividade que se desdobra em uma sequência de atividades, pelas quais perpassam relações entre ciência, tecnologia, sociedade e ambiente, e questões sociocientíficas, sendo a atividade central da aula uma análise socioambiental crítica do uso e produção de combustíveis pelo homem.

Assim, reforçamos que, neste trabalho, as relações CTSA, ou as QSC, apesar de terem potencial para isto, não são objeto da pesquisa, nem tão pouco as situações-problema que desencadeiam as atividades de estudo, mas sim elementos temáticos (contextualizadores) do Ensino de ciências, que cumprem o papel de instrumentos da atividade de ensino.

Quanto ao desenvolvimento dos conceitos da termoquímica pelos alunos, adiantamos que nossa intensão em analisar os indícios de formação desses conceitos está limitada ao tempo de aula versus quantidade/qualidade de questões e discussões pretendidas, a complexidade da trama conceitual relacionada a aspectos econômicos, sociais, ambientais e tecnológicos do contexto histórico-social do aluno, limitações da professora como 
educadora/pesquisadora em processo de formação, limitações dos recursos didáticos do ambiente de aprendizagem, já que trabalhamos com o ambiente real do projeto de Educação Popular. Além disso, entender, por meio do referencial teórico adotado, que o processo de formação de conceitos não é imediato.

O que fica é que as presenças e as ausências dos indícios de formação dos conceitos aqui identificadas, apontam caminhos por onde devemos ou não devemos seguir nas trilhas da constante elaboração, aplicação, avaliação, reelaboração, reaplicação, reavaliação, da atividade de ensino-aprendizagem. Compondo a constante busca do educador pelo aprimoramento desta atividade.

Finalizo esta apresentação com a grata necessidade de salientar, que tanto a construção, quanto a discussão desta pesquisa, não foram realizadas somente por mim, mas por todos os professores, alunos, parceiros de trabalho, grupos de estudo e pesquisa, e disciplinas realizadas por meio do programa de pós-graduação, sendo esta pesquisa um produto de todas estas relações sociais. Produto que contém as limitações de um trabalho inicial sobre possíveis contribuições em direção às convergências e análises propostas, e também inacabado, no sentido de apontar que o caminho nesta direção está apenas começando. 


\section{SUMÁRIO}

LISTA DE SIGLAS

1 INTRODUÇÃO

1.1 A RUPTURA ENTRE O ENSINO-APRENDIZAGEM DE CONCEITOS CIENTÍFICOS ESCOLARES E A REALIDADE DO ALUNO 12

1.2 PROPOSTAS DE ENSINO QUE BUSCAM APROXIMAR O ALUNO DE UM ENTENDIMENTO CRÍTICO DO CONHECIMENTO CIENTÍFICO

$\begin{array}{lll}\text { 1.2.1 } & \text { A proposta CTS } & 14 \\ \text { 1.2.2 } & \text { A proposta da Educação Ambiental }\end{array}$

1.2.3 A proposta da Alfabetização Científica $\quad 20$

1.2.4 A proposta da Natureza da Ciência $\quad 22$

1.2.5 A proposta da Educação Popular

1.3 AS QUESTÕES SOCIOCIENTÍFICAS (QSC) 26

1.3.1 Em busca de uma base teórica para a abordagem de QSC 29

1.4 PROBLEMATIZAÇão E OBJETIVO DA PESQUISA 36

2 REVISÃo BIBLIOGRÁFICA $\quad 40$

2.1 PESQUISAS SOBRE O ENSINO E APRENDIZAGEM DE CONCEITOS RELACIONADOS À TERMOQUÍMICA 40

2.1.1 Literatura Internacional em língua inglesa 40

2.1.2 Literatura nacional e literatura internacional em língua espanhola 44

3 FUNDAMENTAÇÃO TEÓRICA $\quad 51$

3.1 PANORAMA GERAL DAS CONTRIBUIÇÕES TEÓRICAS DE VIGOTSKI, LEONTIEV E DEMAIS AUTORES

3.2 CONCEITOS TEÓRICOS FOCALIZADOS NESTA PESQUISA

$\begin{array}{lll}3.2 .1 & \text { O contexto } & 77\end{array}$

$\begin{array}{lll}\text { 3.2.2 Significado de conceito } & 78\end{array}$

3.2.3 Situação-Problema

3.2.4 Conceito científico e conceito espontâneo

3.2.5 Realidade Concreta 90

3.2.6 Realidade objetal e atividade do sujeito 91

3.2.7 Apropriação e assimilação 92

$\begin{array}{lll}3.2 .8 & \text { Significação } & 93\end{array}$

4 METODOLOGIA $\quad 96$

4.1 Abordagem MetodolóGica 96

\begin{tabular}{ll}
4.2 & CONTEXTO DE APLICAÇÃO DA PESQUISA \\
\hline
\end{tabular}

4.3 PROCEDIMENTOS DE COLETA DE DAdOS 103

4.4 PeRCURSO METOdolóGICO DE ELABORAÇÃO E VALIDAÇÃO DA SEQUÊNCIA DE ATIVIDADES DE ENSINO 105

4.4.1 Segunda etapa da sequência de atividades $\quad 128$

4.4.2 Terceira etapa da sequência de atividades 132

4.4.3 Quarta etapa da sequência de atividades 137

4.4.4 Quinta etapa da sequência de atividades 139

4.4.5 Sexta etapa da sequência de atividades 140

4.5 PROCEDIMENTOS DE ANÁLISE DOS DAdOS

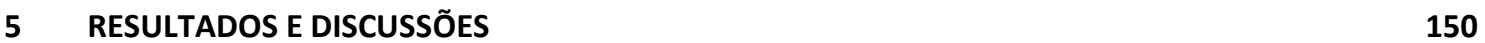

5.1 ANÁLISE DAS INTERAÇÕES DISCURSIVAS 150

5.1.1 Introdução da aula e aproximação entre o tema e a realidade do aluno (episódios 1 e 2) 151

5.1.2 Proposição da atividade ou sequência de atividades da aula: pensar sobre a escolha de um carro sob vários pontos de vista (episódio 3). 157

5.1.3 Primeira etapa da sequência de atividades (episódio 4) 159

5.1.4 Reconhecimento da tarefa e socialização dos conceitos de entalpia, reação de combustão

(episódio 5) 162

5.1.5 Análise em função dos conceitos teóricos focalizados para a identificação e discussão de indícios de formação de conceitos 165

5.1.6 Análise da segunda etapa da sequência de atividades 189 
6 CONSIDERAÇÕES FINAIS

REFERÊNCIAS

APÊNDICES

APÊNDICE A SEQUÊNCIA DE ATIVIDADES E TABELAS DE APOIO $\quad 252$ $\begin{array}{lll}\text { APÊNDICE B } & \text { TEXTOS PRODUZIDOS PELOS ALUNOS } & 257\end{array}$

$\begin{array}{ll}\text { ANEXOS } & 272\end{array}$

ANEXO A TERMO DE AUTORIZAÇÃO DE USO DE IMAGEM E VOZ (PARA MENORES DE IDADE) 273 ANEXO B TERMO DE AUTORIZAÇÃO DE USO DE IMAGEM E VOZ (PARA MAIORES DE IDADE) 274 


\section{Introdução}

\subsection{A ruptura entre o ensino-aprendizagem de conceitos científicos escolares e a realidade do aluno}

O ponto de partida para a organização e realização desta pesquisa tem início na ideia da possível aproximação entre o Ensino de Ciências (EC), principalmente o Ensino de Química, e abordagens que busquem promover a superação da descontinuidade entre a aprendizagem escolar e a realidade social fora da escola. Esta descontinuidade é, em parte, discutida por Engeström (2002), ao se referir a pesquisas que apontam o isolamento do que se aprende na escola em relação ao que se faz fora dela, ou seja, a ausência de uma efetiva contribuição da aprendizagem escolar para o desempenho do aluno fora da escola.

Acrescentamos a esta preocupação a necessidade de uma leitura crítica de mundo, que, de acordo com Freire (1967), possibilite aos estudantes a tomada de consciência das problemáticas sociais nas quais estão inseridos e que os advirtam dos perigos de seu tempo e das prescrições alheias pelas quais passam sem questionar, reproduzidas pela educação tradicional bancária, acrítica, descontextualizada, baseada na memorização e passividade dos alunos, conforme salientam diversos autores (FREIRE, 1987; MIZUKAMI, 1986; ZABALA, 1998; CUNHA et al, 2001; KATO, 2007; KRASILCHIK, 2008; MATTHEWS, 2015). Acrescentamos, ainda, a preocupação com uma formação em que, na sua relação com a realidade, não desconsidere a história e cultura dos alunos, nem estas da história do mundo, para que se reconheça dependente do mundo e dependente do outro na vida em sociedade. (CAMILLO, 2015). Não uma dependência passiva, que apenas espere o outro vir oferecer conhecimento e oportunidades, mas que construa seu próprio conhecimento e oportunidades sabendo que tais construções são construções humanas, e como construções humanas dependem das mediações que ocorrem nas relações sociais de sua realidade, e, nestas relações estão incluídas as possibilidades e adversidades. Entender, de forma crítica, tais mediações pode levar o sujeito à tomada de consciência de seus problemas e 
quais as condições para tornar possível superá-los, visando uma educação libertadora (FREIRE, 1967), na qual o conhecimento escolarizado não seja o único, mas um dos elementos que auxiliem o sujeito no decorrer desse processo.

No âmbito do ensino de ciências, torna-se crucial esse entendimento da dependência do ser humano com o mundo natural e com o outro, dependência cada vez menos perceptível aos olhos da sociedade, concentrada em centros urbanos e dependente, cada vez mais, da tecnologia, o que modifica a aparência, mascarando a essência da relação homem-natureza, como também as relações sociais entre os homens. Nesse contexto, o nosso papel como educadores e pesquisadores da educação é fazer com que a realidade de nosso mundo seja compreendida em sua essência, não apenas nas aparências artificiais.

A preocupação com os aspectos sociais foca-se, principalmente, no desconhecimento, na falta de acesso e na falta de voz e participação dos cidadãos nas tomadas de decisões que governam as direções propostas pelas esferas políticas, econômicas, tecnológicas, científicas e éticas da sociedade onde vivem. $O$ conhecimento científico, necessário para viabilizar tal acesso e participação, é oferecido de tal forma, que se torna desinteressante ou incompreensível, podando a oportunidade para muitos cidadãos em desenvolver algum interesse em acompanhar eventos decisórios que envolvam conhecimento científico. E, além disso, aqueles que se interessam por carreiras científicas, acabam por receber um conhecimento pronto, que irá servir as indústrias, ao mercado, os quais, por sua vez, atenderão somente àqueles que podem pagar pelos produtos gerados por este conhecimento, mantendo, assim, o quadro de reprodução histórica de injustiças sociais relacionadas a este tipo de acessibilidade.

A ciência e a tecnologia, como criações humanas, sofrem influências das necessidades, pretensões e culturas humanas. Na história, a ciência e a tecnologia são desenvolvidas em meio a promessas de melhorar a qualidade de vida do homem nos campos do trabalho, da saúde, do transporte, da comunicação, do cotidiano doméstico e em vários outros aspectos. No entanto, 
poucos têm acesso aos seus produtos benéficos, como já mencionado, sendo que a sociedade pagou, e ainda paga, um alto custo de força de trabalho pelas consequências geradas à própria sociedade, como a intensificação da desigualdade social e as guerras, além das consequências ao meio ambiente, que ainda é explorado de maneira insustentável.

\subsection{Propostas de ensino que buscam aproximar o aluno de um entendimento crítico do conhecimento científico}

No que concerne as nossas preocupações, buscamos, aqui, sistematizar uma breve caracterização de propostas de ensino-aprendizagem provenientes da área da Educação em Ciências e de propostas que tangenciam esta área, cujas relações e complementações apresentam um quadro potencialmente aproximador entre o conhecimento científico e a realidade do aluno, porém, como são passíveis de interpretações simplistas ou podem carecer de fundamentos teórico-metodológicos concretos, necessitam estar sempre em reavaliação e reconstrução para que não se acomodem em reproduções superficiais e conservadoras.

Esta primeira caracterização visa apenas situar brevemente a origem e objetivos destas propostas para que possamos destacar da literatura com quais objetivos e interpretações nos identificamos. Após o capítulo de fundamentação teórica da pesquisa, retomamos a caracterização destas propostas apontando algumas contribuições e convergências da e com a Teoria da Atividade Histórico - Cultural.

\subsubsection{A proposta CTS}

$\mathrm{Na}$ área da Educação em Ciências, o movimento ${ }^{1}$ do campo de trabalho acadêmico, denominado "estudos sociais da ciência e da tecnologia" ou "estudos de ciência, tecnologia e sociedade", deu origem, primeiramente, na Europa e América do Norte, ao movimento Ciência-Tecnologia-Sociedade (CTS), instituído entre os anos de 1960 e 1970 como uma contraposição à

\footnotetext{
${ }^{1}$ Linsingen (2007) refere-se ao termo movimento como um conjunto de sujeitos políticos, integrado ou contraditório, que busca intervir em situações de poder social, baseado em Vaccarezza (1989).
} 
imagem tradicional da Ciência e Tecnologia (C\&T), a qual atribui à ciência e à tecnologia (assumida como ciência aplicada) uma concepção linear de transformação da realidade, que proporcionaria a melhoria contínua da vida humana e do bem estar social, assumida como atividade autônoma que se orienta exclusivamente por uma lógica interna, livre de valorações externas. (LINSINGEN, 2007).

Segundo o mesmo autor, a contraposição a esta concepção C\&T, entre 1960 e 1970, instituída pelo movimento CTS, emerge de um cenário de tensão gerado pelas guerras do Vietnã e Guerra Fria, pelas catástrofes ambientais relacionadas ao aparato científico das armas químicas, biológicas e nucleares posto a serviço da destruição e morte, e pela crítica acadêmica da tradição positivista da filosofia e sociologia da ciência, assumida e promovida por parte dos cientistas e tecnólogos com o objetivo de legitimar formas tecnocráticas de governo, e que ainda continua a orientar projetos curriculares em todos os níveis de ensino, o que também é exposto em Santos e Mortimer (2002).

Entendemos como formas tecnocráticas de governo aquelas nas quais é crescente a dependência da decisão política em relação ao conhecimento científico-tecnológico, tomando este como neutro, determinado naturalmente por comprovação de fatos, como se não houvessem escolhas socialmente determinadas, propósitos pertencentes a interesses políticos e mercadológicos específicos.

Cachapuz (2011), ao discutir sobre tecnociência, poder e democracia, chama a atenção sobre o caráter social da origem da tecnologia, bem como de suas consequências sociais. Chama a atenção no sentido de que, ambas, origem e consequências sociais da tecnologia, são cada vez mais mascaradas para a população, na mesma medida em que a população é distanciada da participação e das decisões políticas. Assim, as reais necessidades da população vão sendo descartadas e substituídas pelas necessidades do mercado dos que já detém o poder econômico, configurando uma tecnocracia ao invés da democracia. Ou seja, a tecnologia a serviço dos detentores do poder econômico e político, ao invés de estar a serviço do atendimento igualitário das necessidades humanas. 
De acordo com Santos (2011), o movimento CTS é um movimento social mais amplo em comparação ao debate do ensino de Ciências que oscila entre os objetivos de formação de cientistas e formação para a cidadania, sendo um movimento de discussão pública sobre políticas de ciência e tecnologia. Surge em função dos problemas ambientais gerados pelo cenário socioeconômico e ambiental da ciência e tecnologia pós segunda guerra mundial, já citado, como também em função de uma mudança de concepção sobre a natureza da ciência e seu papel na sociedade, o que contribuiu para a educação em ciências. Segundo o autor, no ensino de ciências,

o movimento CTS assumiu como objetivo o desenvolvimento da capacidade de tomada de decisão na sociedade científica e tecnológica e o desenvolvimento de valores [...] Dessa forma, o movimento CTS no ensino de Ciências contribuiu para a inserção de temas sociocientíficos, como engajamento em ações sociais responsáveis, questões controvérsias de natureza ética e problemas ambientais contemporâneos. (SANTOS, 2011, p. 23).

Ao final do século $X X$ o movimento CTS é projetado e desenvolvido no currículo do ensino de ciências, bem como em pesquisas deste campo, o que levou a consolidação da linha de pesquisa CTS no ensino de ciências (SANTOS, 2011).

$\mathrm{Na}$ América Latina, Linsingen (2007) relata que o movimento CTS originou-se por meio de um grupo de pensadores ligados a políticas públicas, resultando no que ficou conhecido como PLACTS (Pensamento Latino Americano de Ciência, Tecnologia e Sociedade), com a produção de trabalhos escritos por cientistas e engenheiros, que buscavam tornar a ciência e a tecnologia um objeto de estudo público ligado a estratégias de desenvolvimento social e econômico, compreendendo-as como processos sociais com características que dependem do contexto onde são introduzidas.

Santos e Schnetzler (2010) consideram como marco do início do movimento CTS no Brasil a realização da Conferência Internacional sobre Ensino de Ciências para o século $X X I$, na qual foram apresentados vários trabalhos de pesquisadores estrangeiros sobre CTS no Ensino de Ciências. Segundo Santos (2011), os primeiros trabalhos com denominação CTS no campo do ensino de ciências do Brasil foram publicados na década de 1990 e 
tem expandido significativamente seu número de publicações, estabelecendose, posteriormente, como linha de pesquisa da Educação em Ciências.

No entanto, apesar da continuidade do movimento CTS, foi observada uma redução do mesmo no âmbito internacional, em meio a propostas de ensino que guardam similaridades com os objetivos CTS, mas se propõem com novas denominações, como o "letramento para mudanças climáticas" (BOGATAJ, 2010), "letramento científico funcional”, "ciência para compreensão pública" (AIKENHEAD, 1994), "questões sociocientíficas", "natureza da ciência" - as quais serão apresentadas a seguir, dentre outras, das quais surgem novas linhas de pesquisa em Educação em Ciências ou surgem a partir de orientações políticas locais a propostas de ensino, sendo, algumas delas, mudanças políticas que praticamente excluíram projetos CTS do currículo escolar, como exemplifica Solomon (2003) sobre a política educacional do Reino Unido. Além disso, os equívocos de interpretação das propostas CTS que as levaram a reducionismos, como se referem Pedretti e Hodson (1995) em relação a abordagens CTS como disciplinas ou cursos isolados e abordagens curriculares reduzidas a caixas de texto auxiliares em livros didáticos de ciências.

A incorporação da letra "A", referente a ambiente, para a sigla CTS tornar-se CTSA também divide opiniões. Surge, de acordo com Padretti (2005), como anseio de proporcionar maior ênfase às consequências ambientais dos desenvolvimentos científicos e tecnológicos. Ao nosso ver também vem para reforçar a dimensão social do movimento, entendendo esta como dependente da dimensão ambiental.

De acordo com Vilches, Pérez e Praia (2011) alguns autores consideram esta incorporação desnecessária, pois as origens do movimento CTS estão justamente ligadas, dentre outros, as investigações de Rachel Carson sobre os efeitos nocivos do DDT para o meio ambiente e saúde da população, e o impacto de seu livro "Primavera Silenciosa". Por outro lado, apontam que aqueles que promovem a expressão CTSA não estão afirmando que a dimensão ambiental não esteja presente na expressão CTS, mas pretendem evitar um tratamento insuficiente das questões ambientais nas relações CTS, 
assim como na origem do movimento CTS se pretendeu chamar a atenção para as insuficiências nas considerações relacionadas à sociedade na educação científica. Outra observação desses autores em relação ao surgimento da expressão CTSA é o reconhecimento da integração da comunidade de educadores e investigadores da didática da ciência e da Educação Ambiental, que durante muito tempo permaneceram desligadas, no trabalho para a renovação da educação científica com contribuições convergentes.

De acordo com Santos (2011), uma visão reducionista do movimento CTS reproduz um modelo ideológico de submissão ao sistema tecnológico já estabelecido. A visão crítica com a qual surge este movimento vai em direção oposta da reprodução do modelo vigente, procurando um novo modelo de desenvolvimento. Essa visão crítica, na América Latina, tem sido defendida por uma perspectiva que incorpora os ideais de Paulo Freire (ver, como exemplo, AULER, 2003; AULER; DELIZOICOV, 2006; SANTOS, 2008 e 2009). Estas últimas citações serão discutidas junto ao capítulo de fundamentação teórica.

Portanto, é preciso ter cuidado com interpretações reducionistas do movimento CTS/CTSA, que ora desconsideram sua dimensão social (política, econômica, ética, dentre outras), ora sua dimensão ambiental, ou as consideram separadamente. É preciso buscar uma visão crítica da realidade para superar os problemas do sistema social tecnocrático ao qual estamos submetidos.

Quando neste trabalho falamos em aproximar os conceitos científicos, que se ensinam na escola, da realidade social referente aos mesmos, no campo do Ensino de Ciências, temos que considerar a abordagem crítica dos fatos históricos que envolvem o desenvolvimento sócio-histórico-cultural da ciência e do sujeito para tomada de consciência dos problemas sociais, caso contrário, estaremos reproduzindo as concepções de ensino e aprendizagem que pretendemos superar. 


\subsubsection{A proposta da Educação Ambiental}

A Educação Ambiental (EA) constitui-se como outro movimento que, ao estabelecer interface com 0 ensino de ciências, traz questionamentos semelhantes aos levantados pelo movimento CTS. Tem origem na década de 1960, momento em que eclodiam movimentos sociais provenientes das consequências ambientais da industrialização em países da Europa e América do Norte, e em que se iniciam as discussões sobre as possíveis relações entre a temática ambiental e o processo educativo. (SCHNEIDER-FELICIO, 2012).

De acordo com Guimarães (2011), a EA se estabelece no Brasil, gerando demandas institucionais, somente a partir da Conferência das Nações Unidas sobre o desenvolvimento e o meio ambiente, Unced 92, também conhecida como ECO 92 ou Rio 92, e o Fórum Global, que reuniu ONGs do mundo todo.

A temática ambiental tem sido discutida em diversos setores da sociedade, incluindo o setor educacional e o das pesquisas em Educação. Há uma polêmica intrínseca a essa temática, pois a iminência de déficits de acesso aos recursos naturais fundamentais à humanidade traz preocupações com relação a uma nova proposta de sociedade e de se relacionar com o mundo, ao mesmo tempo em que as questões econômicas e políticas de mercado exigem consumo e produtividade cada vez maiores.

Diminuir os impactos da chamada crise ambiental requer produção de novos saberes e a investigação de perspectivas possíveis e alternativas à sociedade contemporânea, visando a uma sociedade sustentável, cujo posicionamento, do qual concordamos, é bem sistematizado por Loureiro (2006).

Os movimentos CTS e Educação Ambiental possuem semelhanças nas propostas defendidas e diferenças quanto a sua origem, pois apesar de terem surgido na mesma época, vieram de cenários diferentes, já que, de acordo com Linsingen (2007), o movimento CTS, desde seu início, seguiu três direções principais: o campo de pesquisa acadêmico, o campo das políticas públicas e 0 campo da educação. Diferentemente, a EA, apesar de, atualmente, também 
estar presente nestes campos, possui a sua origem associada aos movimentos sociais ambientalistas, promovidos, inicialmente, por Organizações Não Governamentais e conferências internacionais (DIAS, 2004).

Santos e Schnetzler (2010) trazem uma discussão sobre a relação entre a abordagem CTS e suas semelhanças com a proposta da Educação Ambiental, na qual justificam a origem da adoção da sigla CTSA (ciênciatecnologia-sociedade-ambiente) utilizada atualmente por muitos autores e que merece ser destacada na íntegra:

\begin{abstract}
“...um autêntico ensino CTS seria aquele que apresenta uma visão crítica sobre as implicações sociais da Ciência, no sentido das relações de poder e das implicações mais amplas da tecnologia em termos de suas consequências socioambientais em uma perspectiva de justiça social. Neste sentido, o ensino CTS teria um forte caráter de educação ambiental, pois sua visão crítica incluiria necessariamente a reflexão ambiental. Muitas propostas do ensino denominadas CTS, todavia, tem se caracterizado por possuir uma visão reducionista mais focada no uso da tecnologia, do que nas suas implicações sociais. Por essa razão, com o passar do tempo, surgiu a denominação Ciência-Tecnologia-Sociedade-Ambiente (CTSA) que buscou resgatar as questões ambientais no enfoque curricular, perdida nas visões reducionistas." (p. 74).
\end{abstract}

$\mathrm{Na}$ versão das propostas para se trabalhar a Educação Ambiental no ensino de ciências, discussões como estas estão constantemente presentes na literatura, com o intuito de reafirmar uma abordagem crítica e emancipatória (LOUREIRO, 2006) que explore os aspectos sociais, políticos e econômicos, nos quais estão incluídos os processos científicos e tecnológicos e suas consequências socioambientais, todos relacionados ao conhecimento a ser abordado, na perspectiva de formação de uma sociedade consciente, participativa, transformadora e sustentável.

\title{
1.2.3 A proposta da Alfabetização Científica
}

A Alfabetização Científica $(A C)^{2}$ consolidou-se também como uma linha de pesquisa na área de Educação em Ciências, cuja origem histórica não tinha exatamente o propósito de tomada de consciência das injustiças sociais e impactos ambientais causados pelo uso tecnocrático da ciência e tecnologia,

\footnotetext{
2 Termo também representado por "Letramento Científico" ou "Enculturação Científica”, que ora expressam os mesmos objetivos, ora guardam significados diferentes e específicos, e problemáticas. Ver Camillo (2015); Sasseron e Carvalho (2011); Santos e Mortimer (2002); Shamos (1995).
} 
análise crítica dos impactos da ciência e tecnologia na sociedade, e justiça social voltada à população impactada, como na origem do movimento CTS, da Educação Ambiental e da Educação Popular, a qual será discutida mais adiante.

De acordo com Hurd (1997), as raízes da alfabetização científica (AC) se originam desde quando a ciência moderna foi introduzida na civilização ocidental, em 1600, com o surgimento do interesse em como ligar a ciência acadêmica com o mundo da vida do estudante, sob uma perspectiva de que a ciência contribui para "o mais perfeito uso da razão humana" e para o "human wellfare", citando filósofos como Francis Bacon e Herbert Spencer. Perspectiva que, apesar de ainda permear discursos tecnocráticos da atualidade, foi se modificando ao longo da história. Nessa direção, Hurd (1997) cita as colocações de James Wilkinson, cuja palestra intitulada "Science for all", em 1847, criticou o comportamento dos cientistas da época, que permaneciam fechados junto a seus pares, com intenções particulares de produção de conhecimento, desconsiderando a influência de sua produção na vida externa a seu círculo.

Avançando nas mudanças de perspectivas que nortearam 0 desenvolvimento histórico da AC, podemos encontrar em Miller (1983), a preocupação com o nível de $A C$ na população como importante fator na participação democrática em decisões políticas que envolvem a ciência. Em meio a esta preocupação, este autor atribui três dimensões para a AC: 0 entendimento da natureza da ciência; a compreensão de conceitos da ciência; e o entendimento do impacto da ciência e tecnologia na sociedade. Dimensões que vêm ao encontro da proposta CTS.

Em revisão da literatura sobre o histórico e o conceito de $A C$ (SASSERON e CARVALHO, 2011), e a busca por eixos norteadores de AC (SASSERON e CARVALHO, 2008), as autoras colocam como um dos eixos o entendimento, pelo aluno, das relações entre ciência, tecnologia, sociedade e ambiente (CTSA).

A AC, ao longo da história de convergência com o movimento CTS, constitui-se, de acordo com Aikenhead (1994), Iglesia (1995), Holman (1988), 
Rubba e Wiesenmayer (1988) e Solomon (1993), como um dos principais objetivos da abordagem CTS/CTSA, em uma perspectiva de alfabetização científica e tecnológica (ACT).

\subsubsection{A proposta da Natureza da Ciência}

A abordagem da natureza da ciência como linha de pesquisa na Educação Científica, conhecida atualmente na América do Norte, Inglaterra, Austrália e África do Sul como "Teaching Nature of Science" (NOS), também objetiva promover a Alfabetização Científica e o entendimento das condições de produção do conhecimento científico, focando, de acordo com Allchin (2013), três principais tipos de abordagem: histórica, contemporânea e investigativa, para que além do conteúdo científico, também sejam contemplados aspectos da Natureza da Ciência.

De acordo com Lederman (2006), a construção da NOS tem sido defendida, desde 1907, pela Associação Central de Professores de Ciência e Matemática, como um objetivo importante para os estudantes de ciências. Define NOS como aquilo que os estudantes devem saber sobre as características do conhecimento científico em relação à sua produção/desenvolvimento, como também em relação aos fundamentos epistemológicos das atividades da ciência.

Tanto nas intenções da perspectiva CTS/CTSA quanto na AC, 0 entendimento da natureza e filosofia da ciência fazem parte das propostas de ensino e aprendizagem. Em ambas, o NOS se configura como um dos objetivos ou eixos norteadores. Apesar do movimento CTS/CTSA não ser diretamente citado em NOS, há a preocupação em termos da abordagem da sociologia da ciência, que abrange o entendimento da construção desta, desde as relações recorrentes no interior da comunidade científica até as relações desta com a sociedade (ALLCHIN, 2013). De acordo com McComas (2004), existe um domínio de estudos chamado de estudos sociais da ciência, que envolve historiadores e filósofos da ciência junto a sociólogos, os quais focam em observar como os cientistas trabalham em laboratório, em campo, e em outros contextos profissionais, produzindo uma descrição de como a ciência funciona, resultando em informações para o currículo de ciências. 
Particularmente, tememos abordagens que privilegiem a ciência ocidental e a natureza da ciência per se como ponto de partida para o ensino de ciências, ao invés de o ponto de partida ser a realidade do aluno, pois tais abordagens tendem a valorizar a cultura cientifica ocidental em detrimento de outras culturas. No entanto, entender criticamente como a ciência funciona e se estabelece na sociedade em que vivemos, como propõe Allchin (2013), tem potencial para promover a tomada de consciência das controvérsias travadas nessa construção histórica, social e que atende a interesses culturais, contribuindo não só para o entendimento da realidade imediata ao aluno, mas também da realidade que o atinge por meios indiretos e que é consequência da produção de conhecimento científico e tecnológico.

\subsubsection{A proposta da Educação Popular}

A Educação Popular, movimento social que surge como prática educativa à luz de processos sociopolíticos por grupos sociais desfavorecidos por fatores econômicos e políticos, apesar de não estar localizada como linha de pesquisa da Educação em Ciências, é parte integrante do contexto de aplicação da presente pesquisa, concernente ao sujeito aprendiz, e como movimento social da área da educação, possui semelhanças com as propostas de abordagens críticas sociais presentes nas linhas citadas acima.

De acordo com Skeats (1861, apud Flower, 2004), o termo "educação popular" tem origem na Inglaterra, em 1858, quando membros comissionados do parlamento, incumbidos de investigar e relatar as necessidades de medidas para o estabelecimento de uma instrução básica de baixo custo para todas as classes de pessoas, passaram a utilizar o termo em seus relatórios. No entanto, as intenções do governo e industriais ingleses quanto à educação das massas trabalhadoras eram limitadas apenas a fornecer uma instrução básica em função do trabalho, diferente da intenção do povo em conquistar o direito à educação, referindo-se à ideia de "education by the people and with the people".

Segundo Flower (2004), no século XVIII, a classe trabalhadora dos países de língua inglesa não tinha direito à educação formal. Alguns educadores e membros da aristocracia argumentavam que a educação poderia 
confundir e agitar os trabalhadores, fazê-los exigir maiores salários e torná-los muito orgulhosos para o trabalho braçal. Apenas na segunda metade do século XIX, após os Atos de Reforma e os Atos de Educação, foi introduzida uma educação extensiva para as massas trabalhadoras, mantidas de forma escassa pelo estado até 1870, quando igrejas e sociedades religiosas passam a assumir um importante papel na provisão da educação das crianças da classe trabalhadora.

Citando Hogg e Tyson (1969) e Neuburg (1971), Flower destaca o papel dos próprios trabalhadores diante da falta de apoio do governo, em construir escolas, salas, e providenciar recursos materiais, além de desenvolver sua própria forma de educação, como as elaborações das "revistas de pano", os grupos de estudo, as atividades comunitárias, a ajuda mútua, dentre outras, envolvendo a educação de crianças, jovens e adultos.

O autor cita movimentos de educação popular que ocorrem em outras partes do mundo, como Suécia, Filipinas, África do Sul, Austrália e América Latina. Discorre sobre quatro tipos históricos ou "tradições" de educação popular: educação da classe trabalhadora dos séculos XVIII e XIX; educação progressiva e radical do final do século XIX; educação de adultos para democracia no início do século XX; e a Pedagogia do Oprimido de Paulo Freire. Há um consenso entre todas estas literaturas: uma educação que sirva aos interesses das pessoas ordinárias (que, de alguma forma, são privadas do acesso a uma educação que possa ajudá-las a superar sua situação de exclusão social). Há uma premissa de um conflito entre os interesses das classes econômica e politicamente dominantes e os interesses das comunidades que formam a base da sociedade.

Em relação à América Latina, Grossi (1984) destaca que as consequências da história político-econômica sobre os trabalhadores do campo e urbanos foram o contexto do desenvolvimento da educação popular. Segundo Jara (2010), nas décadas de 1960 e 1970, a educação não formal de adultos tem seu desenvolvimento impulsionado pelo impacto da Revolução Cubana e pela perspectiva do "desenvolvimento da comunidade". 
No Brasil, antes do golpe militar de 1964, se gestam o Movimento de Educação de Base (1961 - 1964) e os Centros Populares de Cultura (1962 1964). Paulo Freire formula uma filosofia educativa que estabelece relações entre educação e o ser humano, a sociedade e a cultura. Aponta a conscientização e crítica à educação bancária, dentre outros princípios que deram origem ao conceito de educação libertadora, o que marcou decisivamente, segundo Jara, o pensamento e a prática da educação popular na América Latina dali em diante.

Dessa forma, o público característico da educação popular guarda 0 estigma da exclusão socioeconômica, e se manifesta de várias formas: moradores de favela, trabalhadores do campo e urbanos, indígenas, ribeirinhos, sujeitos privados de liberdade, quilombolas, aborígenes, dentre outros, cada grupo com uma luta e necessidade específica, porém comum no sentido da busca pela superação da exclusão, da transformação de sua realidade.

Atualmente, o movimento da Educação Popular continua com a busca, em sua abordagem, da investigação dos próprios impasses sociais, políticos e econômicos de seus sujeitos, para que por meio de tomadas de consciência sobre os problemas de sua realidade, possam transformá-la, no sentido de tomar o conhecimento como instrumento libertador. (FREIRE, 1967; MÉSZÁROS, 2008; JARA, 2010; GADOTTI, 2012; NARITA, 2014).

Concordamos com Flower (2004), Jara (2010), Paulo Freire e outros que consideram que os princípios e abordagens práticas da Educação Popular são possíveis e desejáveis tanto para a educação não formal quanto para a educação formal, desde que neste sistema se efetive uma transformação estrutural e ideária radical, a partir das necessidades do público envolvido.

Os estudos dos problemas reais, que atingem a vida dos próprios sujeitos para o entendimento de sua condição histórico-social, vem ao encontro da proposta CTS/CTSA para o ensino-aprendizagem de ciências que pretendemos adotar no presente trabalho: a discussão de questões sociocientíficas, e com a perspectiva histórico-cultural, que fundamenta o 
entendimento psicológico-educacional de como se dá a apropriação do conhecimento e o desenvolvimento de conceitos científicos pelo ser humano.

Seguindo a perspectiva CTS, Santos e Mortimer (2002) trazem sugestões de estratégias de ensino, da literatura, como palestras, demonstrações, jogos de simulação de desempenho de papéis, uso de pensamentos divergentes para discussão, simulações, tomadas de decisão, construção de modelos e artefatos tecnológicos, uso de fatos da história da ciência, dentre outros.

Santos e Schnetzler (2010) destacam estratégias de ensino como: discussão estruturada, fóruns e debates, projetos individuais ou em grupos, pesquisa de campo, ações comunitárias, visitas a indústrias e museus, realização de entrevistas com representantes de setores da sociedade, redação de cartas a autoridades e estudo de casos envolvendo problemas reais da sociedade. Tais estratégias de ensino coincidem com estratégias das demais linhas de abordagens para o ensino de ciências citadas anteriormente, visto que, suas propostas e objetivos guardam pontos de convergência.

Dentre as abordagens metodológicas propostas para o ensino de ciências relacionadas à crítica sócio-histórica da influência e implicações da ciência na sociedade, optamos pela abordagem de aspectos sociocientíficos (SANTOS e MORTIMER, 2002) e temas/questões sociocientíficas (QSC) (SOLOMON, 1990; AIKENHEAD, 1994; LEVINSON, 2006; PEDRETTI et al., 2008), originalmente desenvolvidos no campo CTS, a fim de trazer para a sala de aula a discussão de problemas sociais reais, relacionando-os a conhecimentos científicos escolares, acreditando-se na busca e aprimoramento da aproximação entre os conceitos disciplinares de química e os aspectos histórico-sociais a eles relacionados, no contexto social da realidade do aluno.

\subsection{As questões sociocientíficas (QSC)}

As chamadas questões sociocientíficas (QSC), temas sociocientíficos, temas controversos, temas polêmicos ou temas contemporâneos, são uma parte de uma ampla variedade de perspectivas da abordagem CTS. De acordo 
com Levinson (2008), o estudo de QSC foi estabelecido no currículo de ciências de escolas primárias e secundárias de muitos países industrializados, nos quais vem aumentando a conscientização da ciência como uma questão de política pública, refletida pelo aumento da capacidade de posicionamento dos cidadãos diante de questões científicas em júris e conferências.

Sadler e colaboradores (2006) definem as QSC como questões polêmicas reais que contextualizam conteúdos tradicionais às considerações éticas, morais e valorativas dos temas sociais, o que nos leva a expectativas de aprendizagem para além dos conteúdos disciplinares e a expectativas quanto ao interesse dos alunos em buscar o entendimento dos conhecimentos científicos específicos, a fim de entender o problema real como um todo. Assim, a mencionada contextualização de conteúdos disciplinares tradicionais não é considerada como o ponto de chegada, mas sim como meio que possibilita uma compreensão necessária ao entendimento das controversias envolvidas na questão, cujas características, de acordo com Reis (2006), abarcam a multidisciplinaridade, a heurística, a falta de delimitações e a possibilidade de diversas soluções.

Barbosa e colaboradoras (2012) apontam um consenso entre entidades, como o MEC no Brasil, a Royal Society na Inglaterra e a American Association for the Advencement of Science nos EUA, de que a habilidade de posicionamento e tomada de decisões diante de problemas sociais, com envolvimento de questões científico-tecnológicas, consiste em um dos fundamentos para a formação do sujeito contemporâneo. Na mesma direção, os Parâmetros Curriculares Nacionais (PCN) também indicam a necessidade de desenvolver a "competência de emissão de juízos de valor" (CNE, 1998), também trabalhada na abordagem de QSC.

Para que seja possível atender a essa necessidade, bem como à introdução de questões socioambientais críticas no contexto das aulas de ciências, Reis (2007), em seu estudo sobre os temas controversos na Educação Ambiental (EA), aponta aspectos necessários à preparação dos alunos para sua participação em processos avaliativos e decisórios sobre controvérsias socioambientais e sociocientíficas, tais como: 
a) um enquadramento de conhecimentos científicos indispensáveis à apropriação de conhecimentos mais pormenorizados sobre as questões em causa; b) conhecimentos metacientíficos sobre a natureza, as potencialidades e os limites da ciência; c) capacidades de pensamento crítico, tomada de decisões e resolução de problemas; d) atitudes e valores úteis à avaliação das dimensões ética e moral da ciência e da tecnologia; e e) vontade e confiança para lidarem com assuntos científicos (p.127).

Concordamos com estas colocações, entretanto, entendemos que estes aspectos precisam estar em função das necessidades do aluno em relação à tomada de consciência dos problemas e possibilidades que os tocam em sua realidade.

Dentro do mesmo estudo supracitado, Pedro Reis traz diversos trabalhos internacionais cujas investigações evidenciam potencialidades da utilização das controvérsias sociocientíficas em sala de aula, cujo impacto educativo promove a motivação, a pesquisa e o intercâmbio de informação, a reavaliação de atitudes individuais, sentimentos de autoestima, apoio mútuo entre alunos e a apreciação dos conteúdos e experiências de ensino, desde que a aprendizagem seja estruturada de forma cooperativa.

Por outro lado, também enumera diversos fatores observados em outros estudos, relacionados às dificuldades enfrentadas pelos professores em tornar esse tipo de atividade uma prática comum nas salas de aulas, como a falta de literatura e materiais adequados, discordâncias entre direção da escola e professores, dificuldades inerentes ao próprio processo de discussão, o qual exige a abdicação da postura autoritária do professor e a habilidade de controlar e avaliar atividades dessa natureza, tipos de exames nacionais propostos com ênfase na memorização, dentre outras.

Levinson (2008), ao propor uma teoria de abordagem curricular para 0 ensino de questões sociocientíficas, problematiza o aumento de questões sobre avanços da ciência e tecnologia baseadas na mídia, as quais representam um perigoso problema ao simplificar as informações. Logo, versões simplificadas de questões sociocientíficas também dificultam sua inserção no contexto escolar, podendo gerar concepções alternativas. Portanto, o currículo e as atividades propostas nessa perspectiva devem ser cuidadosamente preparados e conduzidos. 
Na perspectiva CTS/CTSA, o uso das questões sociocientíficas (QSC), tais como: alimentos geneticamente modificados, uso de células tronco, causas do aquecimento global, gestão global da emissão de gases poluentes, danos ambientais globais, dentre outros, implicam na discussão de questões contemporâneas polêmicas do mundo real situadas nas esferas política, econômica, científica, ambiental, cultural, ética e moral, a fim de levar o aprendiz a explorar conteúdos tradicionais e utilizá-los de forma contextualizada no entendimento e resolução do problema sociocientífico proposto (SADLER e FOWLER, 2006).

De acordo com Santos (2011), os estudos de QSC referem-se a abordagem e discussão de questões controvertidas, as quais podem ser abordadas por meio de temas amplos ou pela apresentação de exemplos relativamente mais pontuais em sala de aula, dos quais se refere como aspectos sociocientíficos.

Entretanto, consideramos que, para além das sugestões das estratégias de ensino supracitadas e das caracterizações que buscam definir as QSC, é necessário, para o ensino-aprendizagem de ciências, uma base teórica que permita ao professor uma melhor compreensão de como se dá o processo humano de apropriação do conhecimento, para, assim, poder preparar, mediar e avaliar seu trabalho pedagógico com atividades correspondentes à realidade social dos alunos.

\subsubsection{Em busca de uma base teórica para a abordagem de QSC}

De acordo com Zeidler e colaboradores (2005), dentre outros, os estudos de QSC carecem de uma base teórica para sustentar as atividades pedagógicas do professor, sendo que já há alguns estudos teóricos desenvolvidos a partir de investigações sobre a abordagem de QSC Zeidler e colaboradores (2005; 2002); Zeidler e Keefer (2003); Oulton, Dillon e Grace (2004); Oulton, Day, Dillon e Grace (2004) e Levinson (2006; 2008), com base em dimensões éticas da ciência, em princípios do raciocínio de crianças e do desenvolvimento emocional dos estudantes. 
Oulton, Dillon e Grace (2004) relatam que a forma como os educadores em ciência apresentam os problemas controversos das QSC aos estudantes não reconhece a natureza das próprias questões, o que, em parte, contribui para a falta de confiança do público na ciência e nos cientistas como efetivos solucionadores de problemas.

Oulton, Day, Dillon e Grace (2004), em trabalho com professores em exercício, observam a falta de preparo destes para o ensino de QSC, e oferecem um conjunto de focos para ajudarem os professores a serem mais eficazes no ensino de QSC. Iniciam o trabalho com a caracterização da natureza das questões controversas presente no currículo inglês, com multiperspectivas baseadas em valores morais. Apresentam uma discussão da literatura do ensino de QSC sobre princípios que o professor deveria adotar: neutralidade, equilíbrio e razão. O posicionamento dos autores sinaliza que é impossível e, em alguns casos, indesejável, que o professor seja completamente neutro ou sem viés, para que se evite a doutrinação, a não ser que a doutrinação de uma pessoa gere o desejo da apresentação de outros pontos de vista em outra pessoa. Em relação a razão, destacam: o ensino que implica que todas as situações controversas sejam resolvidas apenas pelo recurso da razão é irrealista.

A partir destes princípios teóricos, investigam, dentre outros fatores, as estratégias de ensino e os respectivos princípios que vinham sendo utilizados na prática das QSC pelos professores, concluindo que alguns focos, como os apresentados a seguir, poderiam orientar 0 trabalho dos professores: reconhecer as características da natureza das questões controversas; utilizar estas características para desenvolver princípios de ensino para as QSC para além da neutralidade, equilíbrio e razão; desenvolver políticas de nível escolar e nacional para habilitar os professores a lidar com questões controversas, incluindo requerimentos legais; ensinar estratégias para os alunos lidarem com as questões controversas, não só em termos de conteúdo, mas de comprometimento com as questões.

Assim, o reconhecimento dessas características torna necessário o desenvolvimento de abordagens pelo professor, tais como: promover nos 
alunos a tomada de consciência de que é impossível atingir a neutralidade, fazendo com que eles reconheçam os vieses presentes nos materiais e desenvolvam autonomia para identificá-los; fornecer uma atmosfera de apoio para incentivar confiança e comprometimento com a QSC; encorajar uma mentalidade aberta ao diálogo, com sede por mais informação e disposição para mudar a opinião de alguém à luz de evidências, argumentos e experiências; usar estratégias que encorajam os alunos a reconhecer, respeitar e valorizar a noção de que a posição de uma pessoa em um problema será afetada por sua visão de mundo; enfatizar a importância de evitar o preconceito que vem da falta de uma autorreflexão crítica.

Levinson (2006), considerando a moral e os valores sociais como elementos incorporados nas QSC, mas não como o centro dessas questões, salienta a necessidade de uma base teórica mais forte para o ensino das QSC e propõem três estruturas epistemológicas com o objetivo de contribuir para uma orientação pedagógica ao ensino das QSC: categorias de discordâncias razoáveis; virtudes comunicativas; e modos de pensamento (narrativo e lógicocientífico).

As categorias de discordâncias razoáveis são nove categorias que apresentam níveis de discordância, correspondentes a diferentes papéis atribuídos às evidências presentes na QSC e diferentes dimensões sociais envolvidas. (LEVINSON, 2006, p. 1207-1213). As virtudes comunicativas foram sintetizadas por Levinson (2006) como: paciência, tolerância, respeito pelas diferenças, escuta atenta e pensativa, abertura, autoexpressão honesta, adesão aos procedimentos acordados, liberdade de expressão e igualdade, necessárias para promover um diálogo aberto, inclusivo e não distorcido, entre as discordâncias.

Os modos de pensamento são baseados em Bruner (1986). O modo de pensamento narrativo envolve as vozes dos participantes por meio de verossimilhança na construção de histórias narrativas da vida real. O modo lógico-científico é baseado em evidências científicas, para, por meio de procedimentos, estabelecer provas formais. O primeiro busca explicar um conhecimento; o segundo, fornecer meios de interpretação, sendo ambos 
usados para dar validade a pontos de vista, em meio a uma discordância. (LEVINSON, 2006)

A listagem das categorias de discordância permite ao professor focar em determinada categoria, para, assim, os estudantes entenderem a interação entre evidências, valores morais e éticos, e pontos de vista dentro de uma discordância. Tal modelo sugere promover uma estrutura de acesso com foco explícito nos fatores que os estudantes precisariam destacar em uma discordância específica. Dessa forma, tanto as virtudes comunicativas como os modos de pensamento operacionalizam a estrutura das categorias de discordâncias (IDEM, 2006).

Levinson (2008) propõe cinco modelos de abordagem para o ensino de QSC a partir da literatura do Letramento Científico. Esses modelos são caracterizados de maneira a apresentarem diferentes graus de práxis. Apresentam desde o que é considerado como limitação até a concretização da práxis na abordagem de QSC.

A grosso modo, quanto maior for a autoridade atribuída à ciência e ao conhecimento científico para a discussão/resolução da QSC, maior será a autoridade do professor em sala de aula e mais limitada será a concretização da práxis. Esta seria alcançada com o envolvimento real dos alunos com QSC de sua localidade, trabalhadas para além dos muros da escola, tendo os alunos como protagonistas de transformações sociais, nas quais 0 conhecimento emerge como necessidade dos sujeitos envolvidos e pode ser completamente novo para o professor, o qual se torna um participante na busca pela resolução da QSC.

A definição de práxis tem origem em Jürgen Habermas, citada por Dunne (1973, p. 176), significando "engajamento humano incorporado dentro de uma tradição de compreensões e valores compartilhados em comunidade, vivamente ligados às experiências de vida das pessoas."

Percebe-se, em tese, uma aproximação desse último modelo de abordagem para o ensino de QSC com as características das propostas de 
ensino da Educação Popular. No entanto, não encontramos, nos textos citados, referências de uma linha educacional em relação a outra e vice-versa.

De acordo com Rodrigues e Mattos (2007) trazer um contexto de fora da escola, é trazer, além dos problemas, soluções e conhecimentos deste contexto, trazer também as motivações, valores e fins da atividade que se desenvolve nele. Dessa forma, trazer um contexto de fora da escola é trazer suas dimensões epistemológicas, ontológicas e axiológicas.

Zeidler e colaboradores (2005) oferecem um modelo de trabalho que intenta ilustrar links entre fatores psicológicos, sociológicos e desenvolvimentais centrais para a aplicação de QSC na Educação em Ciências. Baseados nos objetivos do Letramento Científico em desenvolver hábitos mentais, como: adquirir ceticismo, manter a mente aberta, evocar pensamento crítico, aceitar ambiguidades, dentre outros, há a consideração de que estas habilidades podem ser suficientes para tomadas de decisão individuais, mas podem não ser suficientes no caso de uma tomada de decisão coletiva que evoca a construção conjunta de conhecimentos sociais. Para isso, afirmam ser preciso que as proposições CTS/CTSA, Natureza da Ciência, Letramento Científico e o desenvolvimento de estruturas pedagógicas se comprometam com dimensões morais e éticas da Educação em Ciências.

Para estes autores, as QSC focam a capacitação dos estudantes em considerar como questões baseadas na ciência e as decisões tomadas em relação a elas, refletem, em parte, os princípios morais e as qualidades de virtude que acompanham suas próprias vidas, assim como o mundo físico e social em volta deles. Consideram, também, que as interconexões entre ciência, tecnologia e sociedade não existem para os estudantes, independentemente de suas crenças pessoais.

A estratégia pedagógica apresentada pelos autores é fundamentada em uma perspectiva chamada "perspectiva do raciocínio cognitivo-moral" apresentada em Zeidler e Keefer (2003), na qual se busca linhas de pesquisa promissoras ao desenvolvimento de uma estrutura para as QSC. Estas linhas inspiram-se, em parte, em ideias das reformas educacionais propostas por John Dewey (1859-1952), um dos principais fundadores do movimento 
escolanovista, e fundamentam-se, inicialmente e principalmente, em Lawrence Kohlberg (1927-1987), o qual, fundamentado nos estudos sobre os níveis do desenvolvimento cognitivo piagetianos, elabora a Teoria dos Níveis de Desenvolvimento Moral.

Baseados neste trabalho, a estrutura para as QSC, proposta por Zeidler e colaboradores (2005), identifica quatro linhas pedagógicas consideradas importantes para o ensino de QSC: 1) questões da natureza da ciência; 2) questões do discurso em sala de aula; 3) questões culturais; 4) questões baseadas em casos; que, segundo os autores, juntas, promovem o desenvolvimento cognitivo moral e o Letramento Científico. Para resumir como estas linhas são consideradas dentro da proposta pedagógica, colocaremos, abaixo, uma síntese feita pelos próprios autores.

As questões da natureza da ciência tornam-se importantes porque
revelam como variadas visões epistemológicas influenciam a forma
como os alunos selecionam e avaliam a evidência, e como
consideram suas opiniões pré-instrucionais sobre a QSC. As
questões do discurso dirigem nossa atenção para como os alunos
constroem argumentos e utilizam raciocínio falacioso, e nos obrigam
a considerar como as convicções de crença prévias ajudam a
enquadrar respostas emocionais, compromissos de princípios, ou
posições sobre questões morais. As questões culturais nos lembram
que o discurso é inútil sem respeito mútuo e tolerância aos pontos de
vista dissidentes, ao mesmo tempo em que ressalta que as decisões
dos alunos são o resultado da percepção de que, como agentes
morais, são impactados por normas valores e crenças culturais sobre
o mundo natural. As questões baseadas em casos permitem aos
educadores irem além do currículo CTS e cultivar hábitos mentais
que promovam consciência ética, compromisso com a resolução da
questão e sensibilidade moral para ouvir vozes dissidentes,
examinando como o poder e a autoridade estão incorporados nos
empreendimentos científicos. (ZEIDLER et al, 2005, p. 362, tradução
nossa)

A intensão em expor parte do conteúdo destes trabalhos é buscar uma posição frente à fundamentação teórica oferecida para sustentar a abordagem de QSC em sala de aula. Não é nossa intenção fazer uma discussão aprofundada sobre a base majoritariamente cognitivista presente nestes estudos, mas apenas apontá-las, a fim de diferenciarmos nossa proposta de fundamentar a abordagem das QSC na Teoria da Atividade Histórico-Cultural. (VIGOTSKI, 2007, 2009; LEONTIEV 1978,1983).

Percebemos, nos trabalhos que buscam fundamentação teórica para orientar a abordagem das QSC em sala de aula, uma ênfase na preocupação 
com o entendimento da natureza da ciência e da natureza das QSC. E, de maneira geral, esse entendimento, juntamente com 0 entendimento da natureza das interações discursivas em sala de aula, e a consideração de que as anteriores são influenciadas pelos valores morais/culturais dos alunos, seriam, a grosso modo, os princípios fundamentais para deles partirem as orientações pedagógicas às estratégias de ensino. Dessa forma, de acordo com os trabalhos expostos, as QSC teriam o potencial para proporcionar desenvolvimento cognitivo, conceitual e emocional, contribuindo para o crescimento intelectual do aluno.

Entretanto, ainda permanecem algumas questões: como seria possível proporcionar desenvolvimento intelectual efetivamente útil para a superação dos problemas reais dos alunos e da sociedade na qual eles têm papéis, sem que este processo esteja apenas em função da ciência, visto que todas as teorizações estão em função do entendimento da Ciência? Ciência com letra maiúscula e no singular, já que a ciência considerada é primordialmente única e ocidental. Os alunos devem entender como a Ciência é produzida; como a Ciência funciona; como a Ciência repercute na sociedade; se apropriar dos métodos científicos para que "democraticamente" possam participar de decisões da Ciência e para a Ciência; entender como o cientista se relaciona com outros cientistas; como surgem as necessidades da Ciência etc. Tudo em função da Ciência. Mas, e quanto às necessidades dos professores e alunos? Da sociedade? O homem deve se apropriar do conhecimento em função da produção científica ou, a partir de suas necessidades, selecionar 0 conhecimento científico que será útil para a transformação de sua vida? Como se dá o desenvolvimento intelectual por meio da apropriação de conceitos científicos de maneira a modificar sua vida em sociedade?

Apesar de a concepção de QSC propor o desenvolvimento de conceitos científicos escolares em meio a debates de temas controversos reais, os trabalhos anteriores indicam a falta de estudos com foco no desenvolvimento de conceitos científicos e apropriação do conhecimento pelo aluno. Ao nosso ver, permanece a necessidade de uma fundamentação teórica que forneça o entendimento de como se dá o processo humano de apropriação do conhecimento em meio ao desenvolvimento psicológico, de forma a considerar 
o sujeito sócio-histórico-cultural e a superar tendências individualistas de desenvolvimento humano (CAMILLO, 2015), de forma que desenvolvimento humano não esteja em função da ciência, mas sim o contrário.

Talvez o modelo de abordagem para o ensino de QSC apresentado por Levinson (2008), no qual se menciona a práxis, seja o tipo de estratégia que mais se aproxima da superação das tendências individualistas para a abordagem das QSC. Mas como compreender a apropriação de conceitos científicos em meio a práticas educativas que almejam promover a práxis?

Tomando o exemplo de Loureiro (2006), ao problematizar os caminhos abertos por interpretações simplistas das propostas da Educação Ambiental, podemos considerar outro fator passível de ser observado em várias linhas de pesquisa relacionadas à Educação e à Educação em Ciências: "o uso de referências teóricas que se enquadram em perspectivas emancipatórias e dialéticas e a aplicação de metodologias e atividades conservadoras" (p. 47).

Para manter o caráter humano não apartado da sua essência sóciohistórica-cultural da educação que almejamos, optamos pela fundamentação teórica da Teoria da Atividade Histórico-Cultural, da escola liderada inicialmente por L. S. Vigotski (1896-1934) e, posteriormente, por A. N. Leontiev (1903-1979). Visto que, na literatura em que buscamos fundamentação teórica utilizada para basear as pesquisas em ensino e aprendizagem em QSC, não encontramos embasamento em estudos profundos sobre como se dá o processo humano da apropriação do conhecimento e do desenvolvimento de conceitos científicos como fez o grupo de Vigotski, tão pouco considerados dentro da atividade de práxis, como fez o grupo de Leontiev.

\subsection{Problematização e objetivo da pesquisa}

Nosso problema de pesquisa se configura como preocupações teóricometodológicas que envolvem a busca de uma abordagem efetiva, no sentido de que mobilize o aluno a se apropriar do conhecimento, tanto dos conceitos científicos escolares da química, no caso, da termoquímica, quanto das 
discussões socioambientais reais que envolvem a tomada de consciência dos problemas presentes na realidade do sujeito e das implicações da ciência e tecnologia na sociedade, com foco na formação de conceitos da química em sua relação com os problemas socioambientais da realidade concreta do aluno, configurando o conteúdo escolarizado como um dos meios para entender estes problemas, não como um fim em si mesmo. Utilizamos o termo socioambiental para destacar a relação homem-mundo, mas considerando, também, que estão envolvidos em trama complexa de aspectos econômicos, políticos, éticos, morais, culturais, dentre outros.

Uma hipótese levantada ao longo desses estudos sob a perspectiva histórico-cultural foi que a desconexão entre os conceitos científicos escolares e a realidade concreta do aluno poderia estar relacionada com alguma deficiência no processo de formação dos conceitos junto aos contextos que o envolvem, na medida em que estes contextos estejam desconectados da realidade do aluno.

Criticamos aqui os contextos que fecham os conceitos da química dentro dos limites teóricos da disciplina e da ciência per se, que apartam o processo de ensino-aprendizagem de conceitos da atividade humana voltada ao atendimento de suas necessidades de tomada de consciência para 0 entendimento de sua realidade. Buscamos conceitos e contextos que possibilitem ao aluno a tomada de consciência de problemas ambientais, econômicos, políticos, morais e éticos que direta e indiretamente afetam sua vida.

Assim, diante do problema e hipótese colocados, este trabalho propõe a seguinte questão de pesquisa: como se dá o processo de formação de conceitos da termoquímica em meio a uma atividade de análise socioambiental crítica permeada por relações CTSA e questões sociocientíficas controversas (QSC) presentes no contexto social do aluno, sob a perspectiva da Teoria da Atividade Histórico-Cultural?

Para responder a esta pergunta, partindo do princípio de que a formação de conceitos se dá em meio a interações histórico-sociais mediadas pela linguagem, a pesquisa assumiu como objetivo geral analisar indícios do 
processo de formação de conceitos nas interações discursivas, entre alunoaluno e aluno-professor, em aula de química elaborada em meio a abordagem de relações CTSA e QCS por meio do uso de recursos teórico-metodológicos da Teoria da Atividade Histórico-Cultural.

O modo como consideramos o processo de formação dos conceitos é analisado dentro dos limites temporais de uma sequência de aulas com duração total de 5 horas. Para isso, consideramos principalmente os aspectos teóricos envolvidos nos estudos sobre a formação de conceitos de Vigotski e Leontiev referentes a interação entre conceitos espontâneos e científicos, apropriação, significação e generalização.

Os objetos de análise dessa pesquisa foram episódios de interações discursivas de alunos e professores, as quais foram analisadas, priorizando-se os turnos que se mostraram mais expressivos em função da presença dos aspectos teóricos considerados nos estudos sobre formação de conceitos, supracitados, com o intuito de verificar como os novos significados, as novas generalizações e as novas apropriações dos conceitos científicos escolares vão sendo construídos, ou não, coletivamente, em sala de aula, e como contribuem para a tomada de consciência sobre a realidade.

Consideramos os episódios significativos para a análise aqueles que permitem a apreensão do fenômeno observado ao desvelarem a qualidade das ações por meio da manifestação dos indivíduos, de modo que estas ações se tornam reveladoras da apropriação do trabalho coletivo, que é o próprio compartilhamento das ações. (MOURA, 2000; CEDRO, 2008).

Os principais conceitos químicos observados foram os conceitos de reação de combustão e entalpia, considerando suas relações com a malha de conceitos da termoquímica que os envolve. Pretendemos trabalhar estes conceitos com os alunos, considerando seu papel em ajudá-los a entender a realidade que abrange parte dos problemas de nosso tempo, passando pelas questões sociocientíficas (QSC) referentes as controvérsias do sistema produtivo dos biocombustíveis, sua relação com a produção de alimentos e com nossa saúde, o que nos leva à discussão sobre os problemas socioambientais causados pelo agronegócio de monocultura extensiva, 
envolvendo o uso de agrotóxicos associado a sementes transgênicas e às condições de trabalho dos trabalhadores do campo.

A análise das interações discursivas foi complementada com a análise de um pequeno texto produzido pelos alunos, o qual versava sobre a justificativa da escolha de um carro baseada nos estudos e discussões realizados nas aulas.

Mais detalhes são explicados no capítulo Metodologia, enquanto os conceitos da Teoria Histórico-Cutural da Atividade, utilizados para a preparação e análise da sequência de atividades (SAt), são sistematizados e detalhados no capítulo "Fundamentação Teórica". 


\section{Revisão bibliográfica}

Para situar o leitor em relação ao contexto de produção acadêmica na qual se insere este trabalho e a nossa questão de pesquisa, apresentamos uma breve revisão bibliográfica sobre pesquisas preocupadas com o ensino e a aprendizagem de conceitos da termoquímica, considerando trabalhos da área de Ensino de Química, nos últimos dez anos, por meio dos principais periódicos da área do ensino de ciências e ensino de química, nacionais e internacionais, e por meio da base de dados $\mathrm{ERIC}^{3}$.

\subsection{Pesquisas sobre o ensino e aprendizagem de conceitos relacionados à termoquímica}

Em relação às pesquisas da área de Ensino de Química, que versam sobre a discussão do ensino e aprendizagem de conceitos relacionados à termoquímica, considerados nesta pesquisa, a saber: combustão, entalpia, termoquímica, e energia envolvida em processos térmicos, publicadas nos últimos dez anos, buscamos na literatura nacional e internacional por trabalhos preocupados em entender, principalmente, como os alunos se apropriam desses conceitos e quais as estratégias de ensino adotadas.

\subsubsection{Literatura Internacional em língua inglesa}

As pesquisas da literatura internacional em língua inglesa foram buscadas na base de dados ERIC, partindo-se da busca pelos termos dos conceitos da termoquímica citados acima, adicionando-se os filtros de busca "teaching methods", "scientific concepts", "concept formation" e "chemistry".

Os resutados mostraram um total de 16 trabalhos correspondentes aos termos e filtros utilizados, sendo que, a maioria, dividida em dois grupos de cinco trabalhos, tratavam sobre 1) levantamento de concepções prévias sobre os conceitos e 2) uso de experimentos para o ensino dos conceitos.

\footnotetext{
${ }^{3}$ Education Resources Information Center é uma Biblioteca online de Pesquisa e Informação em Educação. Patrocinado pelo Instituto de Ciências da Educação dos Estados Unidos.
} 
O primeiro grupo tratava de uma variação de levantamentos de concepções prévias de alunos e professores, envolvendo os conceitos de termoquímica (LEE, 2014; MÉTIOUI; McWILLIE, 2015; OPITZ, et al, 2015; SARICAYIR, et al, 2016; HARRER, 2013).

Em Lee (2014), além do levantamento de concepções de professores sobre energia em forma de calor, transferência de calor e isolamento térmico, foi aplicado um método de mudança conceitual, por meio do qual se constatou que os professores podem entender melhor os conceitos quando analogias e experiências da vida diária são usadas. Em Saricayir e outros (2016), foram levantados níveis de concepções sobre calor, temperatura, entalpia e mudança de energia. Os resultados mostraram que os níveis de entendimento dos conceitos eram muito baixos.

Foi uma surpresa encontrar trabalhos tão recentes que continuam a pesquisa sobre levantamento de concepções prévias dentro da perspectiva de mudança conceitual ou fora dela. Pode-se encontrar em Mortimer (1996) uma crítica às aplicações de estratégias construtivistas de mudança conceitual em sala de aula, que, muitas vezes, resultam na reafirmação do pensamento de senso comum ao invés da construção de conceitos científicos pelo aluno. De acordo com Gaspar (2014), a ineficácia das propostas de ensino com origem nas pesquisas sobre concepções prévias tornou-se praticamente consensual. Os resultados das mesmas, aplicadas desde a década de 1970, em várias partes do mundo, apontam um mesmo padrão:

(...) a cada conceito investigado, as ideias alternativas de crianças e adolescentes são pessoais, fortemente influenciadas pelo contexto do problema, bastante estáveis e extremamente resistentes à mudança, de tal modo que é possível encontrá-las até mesmo entre estudantes universitários. (p. 76)

Os próprios resultados nos sinalizam a importância da realidade do sujeito na formação de seus conceitos, inclusive relacioná-la ao processo de formação de conceitos científicos, como aponta Lee (2014); no entanto, as propostas de ensino-aprendizagem por mudança conceitual pouco consideram a realidade do aluno para além do que acontece dentro da sala de aula.

O segundo grupo de pesquisas refere-se àquelas que destacam modelos de aplicação de experimentos para a mediação do ensino dos 
conceitos de termoquímica. (MUELLER; ANDERSON; WALLINGTON, 2009; KEERATICHAMROEN et al, 2010; PUNCKT et al, 2015; JAKUBOWSKA, 2016; BOPEGEDERA; PERERA, 2017; VISINTAINER; LINN, 2015).

Punckt et al (2015) propõem modelos de experimentos simples sobre o conceito de combustão, contextualizados ao estudo da dinâmica de incêndios. Keeratichamroen et al (2010) utilizam-se de experimento de queima da farinha de tapioca, juntamente com a abordagem investigativa guiada (predição, observação, explanação), a fim de envolver os estudantes ativamente em seu aprendizado sobre combustão explosiva. Os demais trabalhos propõem modelos, materiais e demonstrações de experimentos. Todos apontam os experimentos como ferramentas que favorecem a aprendizagem dos conceitos da termoquímica.

Dos seis trabalhos restantes, dois deles estudam o uso de tecnologias da informação e comunicação (TIC) para o ensino e aprendizagem de conceitos da química, dentre eles, entalpia e energia. Bowman (data não informada) estuda o uso/não uso de materiais disponíveis online e sua relação com o desempenho de alunos. Percebe que o maior número de tentativas de acesso às questões online (que continham os conceitos), aliado ao menor tempo médio de acesso indicava os tópicos em que os alunos tinham mais dificuldades. E Visintainer e Linn (2015) avalia o uso de uma ferramenta tecnológica (TIC) para o ensino de energia, sob o tema mudanças climáticas globais. Reporta que houve a construção de conexões entre o uso cotidiano da energia e o aumento da temperatura global.

Outros dois trabalhos destacam o uso de jogos para o ensino de conceitos da termoquímica. Bell et al (2009) propõem, dentre outros tipos de jogos e conceitos, um jogo de cartas para a compreensão do custo energético envolvido nas quebras e formação de ligações (entalpia) envolvendo as estruturas de Lews. Tarhan et al (2013) comparam duas turmas durante uma intervenção no ensino de reação de combustão: uma sob o ensino tradicional e outra sob a perspectiva da aprendizagem colaborativa, utilizando-se de jogo do tipo quebra cabeça. 
A partir do tema do cotidiano "Alimentos prontos", Oliver-Hoyo, Pinto e Llorens-Molina (2009) utilizam a abordagem da aprendizagem baseada em problemas e a abordagem investigativa guiada, com o objetivo de calcular 0 calor produzido pelo processo de aquecimento de alimentos prontos. É relatado que o contexto das atividades, ligadas ao contexto do mundo real, conecta uma variedade de conceitos químicos e oportuniza a prática de operações como conversões de unidades e resolução de problemas algorítmicos.

Em Chang (2009), alunos entre 15 e 17 anos são acompanhados com entrevistas durante e após curso extraclasse sobre termoquímica, em que se busca investigar as dificuldades e facilidades dos estudantes na aprendizagem desse tema. As entrevistas revelaram, dentre as dificuldades de aprendizagem, a presença de fortes concepções alternativas; informações e pressupostos omitidos por parte dos professores; perspectivas alternativas, porém válidas, não consideradas pelos professores.

Consideramos os experimentos, as TICs, os jogos, a abordagem baseada em problemas e a abordagem investigativa como exemplos de diversos tipos de instrumentos mediadores para o ensino-aprendizagem de conceitos científicos, desde que não se bastem a ter um fim em si mesmos, explorando apenas a lógica interna dos conceitos envolvidos, contribuindo, assim, para a reprodução da construção de uma visão acrítica e descontextualizada do conhecimento científico, que desconsidera a realidade do sujeito.

De acordo com o que é relatado nos trabalhos, parece que todos aqueles que propõem algum tipo de intervenção diferente da tradicional, apresentam algum resultado positivo em relação à aprendizagem dos referidos conceitos. Entretanto, a maioria das propostas, exceto Visintainer e Linn (2015) e Oliver-Hoyo et al (2009), parece, ao nosso ver, ter o entendimento do conceito químico como um fim em si mesmo.

Não foram encontrados trabalhos sobre o ensino-aprendizagem escolar dos conceitos da termoquímica com abordagem de QSC ou da Teoria da Atividade Histórico-Cultural campo de busca utilizado. 


\subsubsection{Literatura nacional e literatura internacional em língua espanhola}

$\mathrm{Na}$ literatura nacional a mesma busca foi realizada nos principais periódicos e eventos de Educação em Ciências e Educação em Química. Na língua espanhola, a busca foi realizada no periódico Enseñanza de las Ciencias. Os termos utilizados foram "termoquímica", "combustão", "energia" e "entalpia", acompanhados do termo "ensino de química". Procuramos por trabalhos preocupados em entender, principalmente, como os alunos se apropriam desses conceitos e quais as estratégias de ensino-aprendizagem utilizadas ${ }^{4}$.

De um total de 24 trabalhos correspondentes ao interesse da busca, 4 trabalhos referem-se a levantamento de concepções prévias sobre conceitos da termoquímica (SANGIOGO et al, 2011; BRITO e CASTRO, 2010; COSTA; SÁ; SILVA, 2008; SILVA e PITOMBO, 2006); 4 trabalhos destacam a análise de interações discursivas em salas de aula para o ensino de conceitos da termoquímica, dos quais Isidório, Silva e Quadros (2013) identificam a presença de discurso dialógico interativo e não interativo de autoridade (MORTIMER e SCOTT, 2002), na aplicação de uma sequência didática que busca aproximar a química do cotidiano dos estudantes por meio de atividades experimentais e perspectiva dialógica, promovendo interações dos alunos com os conceitos.

Firme (2012) analisa a construção discursiva de professores ao trabalharem conceitos da termoquímica sob a abordagem CTS, no intuito de identificar a emergência do discurso argumentativo. O uso do modo descritivo e de elementos argumentativos contribuíram para a introdução de significados científicos em sala de aula. Silva (2008) caracteriza estratégias enunciativas de dois professores de química com o intuito de analisar como essas estratégias oportunizam o desenvolvimento de conceitos da termoquímica por alunos do Ensino Médio. Silva e Mortimer (2010), em trabalho derivado do anterior,

\footnotetext{
${ }^{4}$ Gostaríamos de adiantar que dentro desta busca que nos propomos fazer, não encontramos trabalhos que se utilizassem de QSC e/ou da Teoria Histórico-Cultural da Atividade para e estudo sobre o ensinoaprendizagem dos referidos conceitos da termoquímica.
} 
caracterizam tempo e frequência de categorias de gênero de discurso (perspectiva bakhtiniana), na dinâmica discursiva de sala de aula, utilizadas para o ensino de processos da termoquímica.

Sob forma de texto teórico argumentativo, Silva (2005) expõe justificativas por meio das quais se posiciona contra o ensino do conceito de entalpia no Ensino Médio, sendo sua principal justificativa a confusão feita, na explicação de muitos professores, entre calor de reação e entalpia.

Discordamos de Silva (2005), primeiro porque o conceito de entalpia é recorrente nos exames vestibulares e não é o único passível de equívocos no processo de ensino-aprendizagem, segundo porque o sujeito não deve ser privado de se apropriar do conhecimento produzido historicamente pela humanidade só porque pode ser exposto a concepções equivocadas. O que deve haver é o investimento na melhoria da qualidade da educação em toda estrutura de seu sistema, e, principalmente, na forma de como concebemos a ideia de educação.

Neste primeiro grupo de 9 trabalhos há a preocupação de como as concepções prévias e interações discursivas contribuem para o ensinoaprendizagem, porém não há uma análise de como se dá a apropriação dos conceitos da química pelos alunos, apenas pelos professores.

O maior grupo, composto por 15 trabalhos destaca propostas de ensinoaprendizagem para os referidos conceitos. O quadro 1 apresenta uma sistematização desse grupo de trabalhos, em grupos menores, de acordo com o tipo de proposta de ensino-aprendizagem destacada pelos autores. 


\begin{tabular}{|c|c|c|}
\hline \multicolumn{3}{|c|}{ Propostas de estratégias de ensino-aprendizagem } \\
\hline \multirow{4}{*}{$\begin{array}{l}\text { Destaque para o } \\
\text { uso da } \\
\text { problematização }\end{array}$} & Estudo de Caso (investigativo) & Freita-Reis e Farias (2014). \\
\hline & $\begin{array}{l}\text { Utilização de atividades experimentais } \\
\text { sob a perspectiva da resolução de } \\
\text { problemas }\end{array}$ & Goi e Santos (2009). \\
\hline & $\begin{array}{l}\text { Situação-problema relacionando aspectos } \\
\text { químicos, históricos, econômicos e } \\
\text { ambientais }\end{array}$ & Ferreira (2008). \\
\hline & $\begin{array}{l}\text { Perspectiva experimental, histórica, } \\
\text { problematizadora e investigativa }\end{array}$ & Pulido e Silva (2011). \\
\hline \multirow{7}{*}{$\begin{array}{l}\text { Outras estratégias } \\
\text { em destaque }\end{array}$} & Perspectiva da Educação Ambiental & Moradillo e Oki (2004). \\
\hline & Uso de modelagem & Sousa e Justi (2010). \\
\hline & Iha Interdisciplinar de Racionalidade & Milaré (2013). \\
\hline & Proposta de experiento & $\begin{array}{l}\text { Braathen, et al (2008); } \\
\text { Carvalho, et al (2007). }\end{array}$ \\
\hline & Abordagem CTS & $\begin{array}{l}\text { Menezes, et al (2013); } \\
\text { Santos (2007). }\end{array}$ \\
\hline & Uso de jogos & $\begin{array}{l}\text { Soares (2004); } \\
\text { Soares e Cavalheiro (2006). } \\
\text { Crespo e Giacomini (2011) }\end{array}$ \\
\hline & $\begin{array}{l}\text { Perspectiva da História e Filosofia da } \\
\text { Ciência }\end{array}$ & Fabrício, et al (2011). \\
\hline
\end{tabular}

Quadro 1 - Pesquisas que apresentam estratégias de ensino-aprendizagem para conceitos da termoquímica

Foi observado que, dentre os trabalhos propositores de estratégias de ensino-aprendizagem, alguns deles tinham em comum o destaque para 0 caráter problematizador. Estes trabalhos complementam este caráter com abordagens investigativas, experimentais, históricas, como também aspectos sociais, econômicos e ambientais. Os trabalhos, que não destacam o caráter problematizador, explicitam destaque para outras perspectivas, como mostra 0 quadro 1.

Em relação aos aspectos que se aproximam da nossa questão de pesquisa, ou seja, de como se dá o processo formação de conceitos da termoquímica pelo aluno, dentro da estratégia de ensino-aprendizagem, foi observado que, a maioria dos trabalhos não detalha a análise sobre a formação dos conceitos envolvidos no sentido de demonstrar como se deu o desenvolvimento desse processo pelos alunos. A maioria ou apenas apresenta as propostas, os instrumentos de ensino, ou relata observações, como mostramos, a seguir. 
Dentre todos os trabalhos que compõem o quadro 1, Braathen et al (2008) não analisam aspectos referentes à aprendizagem dos conceitos da química, já que o objetivo é apresentar uma proposta de experimento a partir dos materiais e cálculos envolvidos. Santos (2007) discute teoricamente e apresenta uma proposta CTS de um livro didático. Fabrício et al (2011) apresentam uma elaboração de material didático por licenciandos em química, composto por uma compilação de aulas no formato de Unidades Didáticas, contextualizadas na perspectiva da História e Filosofia da Ciência. Crespo e Giacomini (2011) encontram, em sua revisão bibliográfica sobre atividades lúdicas no ensino de química, jogos para o ensino-aprendizagem de conceitos da termoquímica, e, assim como os demais, não aplicam as propostas. Por outro lado, todos indicam as potencialidades das mesmas como enriquecedoras do processo de ensino-aprendizagem dos referidos conceitos, em seus argumentos propositivos e em análises da literatura.

Os demais trabalhos constantes no quadro 1 analisaram as aplicações das propostas de ensino-aprendizagem. Dentre estes, todos trazem resultados positivos em relação à intensão da proposta e a reação dos alunos à mesma. Exceto Ferreira (2008), que apesar de relatar as contribuições da abordagem da História da Química para a contextualização dos conteúdos, apresenta a dificuldade em relação à intensão da proposta: a dificuldade de licenciandos em elaborar situações problematizadoras, que utilizem de conhecimentos químicos para solucionar os problemas, a partir do seu cotidiano, o que nos aponta a importância de se investir nesses estudos para a formação inicial de professores. Milaré (2013) não aborda conceitos da termoquímica como centrais no desenvolvimento da Ilha Interdisciplinar de Racionalidade, mas menciona que trabalha, em um dos momentos, com os licenciandos, a possibilidade de abordagem de conceitos da termoquímica contextualizados no estudo do funcionamento do micro-ondas.

Em relação à reação dos aprendizes às propostas, todos relatam efeitos positivos sob a postura do aluno diante das atividades. Uma variedade de aspectos é observada. Goi e Santos (2009) relatam que a articulação entre o trabalho experimental e problemas semiabertos pode ser eficaz para a aprendizagem de conceitos, procedimentos, atitudes, e para o aprimoramento 
da argumentação pelos estudantes. Moradillo e Oki (2003) relatam que a relação feita entre os conceitos químicos e ambientais promoveu a superação da exploração simplista do "tripé" ambiente - química - poluição, resultando em uma visão não reducionista do ambiente. Carvalho et al (2007), através de resultados quantitativos das respostas obtidas de questionários pré e pós teste referentes aos conceitos da termoquímica, indicam um aumento da apropriação dos mesmos pelos estudantes, atribuindo esta apropriação principalmente ao emprego de linguagem e conceitos pertencentes ao cotidiano. Soares e Cavalheiro (2006) relatam que o uso do jogo promoveu visível melhora no aspecto disciplinar (comportamento dos alunos), maior envolvimento entre alunos e docentes, havendo fortificação de laços afetivos entre alunos e professores, divertimento e construção de conhecimento, sem a demonstração desta última.

Alguns trabalhos, além de relatar sobre a reação dos aprendizes à estratégia de ensino, trazem a produção de textos e transcrições de falas desses aprendizes. Estas, de origem em interações discursivas de sala de aula e de entrevistas.

Freitas-Reis e Faria (2015) aplicam a chamada Estratégia de Ensino Estudo de Caso, de caráter investigativo, sob o tema "Alimentos Embutidos", e trazem falas de alunos nas quais identificam levantamento de hipóteses, argumentação, posicionamento diante de questões éticas, econômicas, sociais, ambientais e explicações envolvendo conceitos químicos, utilizados para solucionar o caso.

Souza e Justi (2010) usam a modelagem para auxiliar as representações de átomos e moléculas na energia química envolvida em reações endo e exotérmicas. Trazem diálogos entre alunos e professora para demonstrar como a estratégia da modelagem auxiliou o entendimento dos conceitos pelos alunos, sendo o trabalho com maior riqueza de detalhes em demonstrar como se deu o desenvolvimento dos conceitos pelos alunos.

Soares (2004) traz falas de entrevistas referentes a impressão de professores e alunos sobre a aplicação dos jogos. Em relação ao entendimento dos conceitos, os professores destacam que o desempenho dos alunos nas 
provas avaliativas foi melhor do que nos anos anteriores. Os alunos dizem ter entendido os conceitos com mais facilidade em comparação com aulas tradicionais, de forma a não precisar decorá-los. Entretanto, os alunos não explicitam, em suas falas, como ou o que entenderam.

Dos trabalhos que destacam a produção textual dos alunos, Pulido e Silva (2011) aplicam uma sequência didática que abarca aspectos da História da Ciência, experimentação, problematização e investigação. Trazem textos em que os alunos explicitam, de acordo com os autores, levantamento de hipóteses e explicações de resultados em que os conceitos são utilizados para pensar o problema.

Menezes et al (2013), por meio de questionários pré e pós teste referentes aos conceitos, e por entrevistas pós teste com os alunos, relatam que as turmas-controle, nas quais foram aplicadas as chamadas sequências de ensino-aprendizagem sob a abordagem CTS, apesar de apresentarem alguns erros conceituais nas entrevistas, apresentaram, de modo geral, uma aprendizagem, segundo os autores, mais efetiva em relação às turmas de ensino tradicional.

Dos trabalhos que analisaram a aplicação das estratégias de ensino, nos parece que os principais fatores que contribuem para a melhora da aprendizagem dos conceitos são as próprias estratégias, as quais enriquecem a mediação entre alunos e professores, e estão em função do entendimento dos conceitos químicos. Mesmo as mediações feitas por meio da aproximação do conteúdo escolar com a linguagem e o cotidiano do aluno parecem estar direcionadas apenas para o entendimento dos conceitos químicos como o objetivo final.

Todos estes trabalhos têm seu mérito e importância nos contextos em que foram desenvolvidos e trazem contribuições para o ensino de química, mas se continuarmos planejando o ensino de conceitos químicos cujo fim seja o entendimento dos mesmos e não da realidade da qual fazem parte, que por sua vez influencia a vida do aluno direta ou indiretamente, continuaremos reproduzindo o sistema educativo que criticamos. Não superaremos o encapsulamento do conhecimento escolar, como coloca Engeström (2002). A 
desconexão entre os conceitos científicos escolares e a realidade do aluno leva ao entendimento parcial e aparente de ambos, incapaz de contribuir para a tomada de consciência dos problemas que afetam o sujeito e as possibilidades de superá-los, ou seja, incapaz de libertar.

Assumindo esta responsabilidade, pretendemos buscar nas estratégias temáticas e problematizadoras CTSA, o uso de QSC como instrumentos mediadores de ensino-aprendizagem de conceitos científicos escolares sob a fundamentação da Teoria Histórico-Cultural da Atividade com o intuito de superar o ensino de conceitos da química fechados no entendimento per se. 


\section{Fundamentação Teórica}

A fundamentação teórica, assumida como base de apoio a preparação e análises realizadas nesta pesquisa, está sistematizada em dois itens principais. O primeiro apresenta um panorama geral das contribuições teóricas de Leontiev, Vigotski e demais autores, focalizando a convergência de suas ideias com a presente pesquisa. $O$ segundo item detalha e discute a apropriação de alguns conceitos desenvolvidos por esses autores e que guiaram a preparação da sequência de atividades (SAt) e a análise das interações discursivas desenvolvidas nesse estudo, até o momento.

Esta pesquisa se insere no locus de busca por uma educação humanística em ciências, mais especificamente no ensino e aprendizagem da química. Esse caráter humanístico da educação está relacionado ao fato de não apartar o sujeito de sua história e de sua cultura, como também não o apartar da história e da cultura da humanidade, não o apartando como agente na apropriação e construção do conhecimento produzido pela humanidade.

Assumir esta perspectiva implica em reconhecer a urgência na necessidade de incluir aspectos sócio-histórico-culturais pertencentes à realidade do aluno nas aulas de química, de modo que os conceitos abordados façam sentido para o mesmo, contribuindo para o seu desenvolvimento psicológico, intelectual, ético e moral. Não os significados dicionarizados dos conceitos, mas os que complexifiquem a sua relação com o mundo de uma forma consciente e crítica, que o liberte de condições alienadas e excludentes de acesso aos conhecimentos historicamente produzidos pela humanidade.

\subsection{Panorama geral das contribuições teóricas de Vigotski, Leontiev e demais autores}

Remetemo-nos, agora, a uma reflexão de A. N. Leontiev que merece destaque para fundamentar o processo de produção dos conhecimentos da humanidade sob a perspectiva Histórico-Cultural. Segundo Leontiev (1978), o desenvolvimento humano, considerado sob sua perspectiva filogenética, ou seja, ao longo da história das gerações humanas, ocorre em sociedade, 
caracterizando-se o homem, portanto, como um ser histórico-cultural que desenvolve e transmite, de geração em geração, sua cultura material e intelectual produzida historicamente.

A principal atividade produtiva e criadora que manteve a fixação das aquisições socioculturais é o trabalho. Por meio do trabalho, o homem cria objetos para satisfazer suas necessidades e igualmente os meios de produção desses objetos. O seu saber-fazer cristaliza-se nos seus produtos. Cada geração começa a sua vida em um mundo de objetos e de fenômenos criado pelas gerações precedentes. Apropria-se dessas riquezas, participando no trabalho e em diversas atividades sociais. $O$ mesmo ocorre com 0 desenvolvimento do pensamento ou a aquisição do saber. $O$ pensamento e 0 saber de uma geração formam-se a partir da apropriação dos resultados da atividade cognitiva das gerações precedentes.

O processo de apropriação desse mundo, logo, do conhecimento produzido nele, é, ao mesmo tempo, o processo de formação das faculdades específicas do homem. Segundo Leontiev (1978):

\footnotetext{
Este processo é sempre ativo do ponto de vista do homem. Para se apropriar dos objetos ou dos fenômenos, que são o produto do desenvolvimento histórico, é necessário desenvolver em relação a eles uma atividade que reproduza, pela sua forma, os traços essenciais da atividade encarnada, acumulada no objeto. (p. 268)
}

A formação das faculdades específicas do homem está relacionada com o desenvolvimento de órgãos cerebrais, os órgãos fisiológicos, que funcionam da mesma maneira que os órgãos habituais, mas distinguem-se destes por serem neoformações que aparecem no decurso do desenvolvimento ontogênico, o qual, a grosso modo, se dá durante o tempo de vida do indivíduo.

O processo de apropriação é resultado de uma atividade efetiva em relação ao objeto criado pela cultura humana. Para este processo ser uma atividade adequada, é necessário que esta reproduza as características da atividade cristalizada nos sistemas que formam o objeto. No entanto, o objeto, por si só, não promove o aparecimento dessa atividade no sujeito. Isto só é possível na comunicação com outro sujeito. "Assim, a criança aprende a atividade adequada. Pela sua função, esse processo é, portanto, um processo de educação" (p. 272). (grifos do autor). 
Aproveitando esta colocação de Leontiev, gostaríamos de relacioná-la com o uso de instrumentos mediadores, os quais, consideramos que, assim como os objetos (conceitos), também precisam ser apropriados/compreendidos. Dessa forma, o experimento, o jogo, o modelo e a questão sociocientífica não promovem, por si só, o aparecimento da atividade no sujeito sem a comunicação com outro sujeito. Daí a importância da mediação do professor.

Continuando com Leontiev, quanto maior o desenvolvimento cultural, maiores e mais complexos se tornam os sistemas educacionais, políticos, científicos, tecnológicos, econômicos, artísticos, dentre outros, que formam o conjunto da produção humana. No entanto, não são todos os sujeitos que tem acesso ao que essa produção possa oferecer, pois o crescimento da produção levou à alienação do produto em relação a quem o produz. Esta desigualdade não provém das diferenças biológicas entre os homens, mas da desigualdade econômica, desigualdades de classes e com a diferença entre suas relações com as aquisições de aptidões e faculdades humanas. Há, ainda, quem defenda uma justificativa biológica para tais desigualdades, como ocorreu com a ideia da eugenia 5 .

A partir desse delineamento, há um reconhecimento de que o verdadeiro problema não está na aptidão ou inaptidão dos sujeitos para dominarem as aquisições da cultura humana e/ou contribuírem com elas, mas na falta de acesso pelas pessoas que foram alienadas de seu trabalho ou da própria vida no círculo social produtor dessas aquisições e se encontram oprimidas e excluídas.

É necessário que cada "povo tenha a possibilidade prática de tomar um caminho de um desenvolvimento que nada entrave" (idem, p. 283). A humanidade voltada para o progresso deveria tender a este fim, mas isso só seria possível criando um "sistema de educação que lhes assegure o

\footnotetext{
${ }^{5}$ Eugenia é um termo criado em 1883 por Francis Galton (1822-1911), significando "bem-nascido". Galton definiu Eugenia como "o estudo dos agentes sob o controle social que podem melhorar ou empobrecer as qualidades raciais das futuras gerações, seja física ou mentalmente". O tema é bastante controverso, particularmente após o surgimento da eugenia nazista, que veio a ser parte fundamental da ideologia de "pureza racial", a qual culminou no Holocausto.
} 
desenvolvimento multilateral e harmonioso que dê a cada um a possibilidade de participar, enquanto criador, em todas as manifestações de vida humana". (ibidem, p. 284).

Nesta reflexão, Leontiev aborda um contexto universal do processo de desenvolvimento material e intelectual humano, cujas necessidades biológicas permanecem atualmente, pois são universalmente humanas, assim como o trabalho se desenvolveu como atividade de produção material e intelectual humana e, posteriormente, o conhecimento do processo como um todo, desta produção, foi desvinculado dos sujeitos que produzem os bens materiais. Essa alienação permanece como reflexo histórico em maior evidência nos chamados países emergentes, como é o caso do Brasil e demais países da América Latina, nos quais a maioria da população foi e ainda permanece historicamente e culturalmente privada da produção humana, do conhecimento necessário para se reconhecer como sujeito ativo de sua história.

No contexto histórico da educação brasileira, Paulo Freire, também sob a perspectiva marxista, discute a questão do trabalho e da educação. Coloca a concepção de educação bancária como instrumento de alienação e opressão:

Na visão "bancária" da educação, o "saber" é uma doação dos que se julgam sábios aos que julgam nada saber. Doação que se funda numa das manifestações instrumentais da ideologia da opressão - a absolutização da ignorância, que constitui o que chamamos de alienação da ignorância, segundo a qual esta se encontra sempre no outro (FREIRE, 1987). (aspas do autor).

Apesar dessas linhas terem sido escritas ao final da década de 1960 e de seu trabalho com a alfabetização de adultos, no Brasil, datar das décadas de 50 e 60 do século XX, tais críticas podem ser aplicadas para os dias de hoje.

Para superação da educação bancária, propõe uma concepção de educação que possibilite ao homem a discussão de sua problemática e da tomada de consciência de sua inserção na mesma, dos perigos de seu tempo, da importância de estar em diálogo constante com o outro, para que não permaneça submetido a prescrições e, assim, se liberte para se tornar sujeito de suas decisões, de sua história. Este trabalho encontrou, nas palavras de Freire (1967), o sentido que buscamos adotar, quando pensamos em tentativas 
de aproximar o aluno de sua realidade ao entrar em contato com seu objeto de aprendizagem, pois tais tentativas de aproximação podem ter muitos sentidos, inclusive vazios ou superficiais; no entanto, é preciso esforço para que busquemos aproximar o educando de sua realidade na seguinte perspectiva:

Entendemos que, para o homem, o mundo é uma realidade objetiva, independente dele, possível de ser conhecida. É fundamental, contudo, partirmos de que o homem, ser de relações e não só de contatos, não apenas está no mundo, mas com o mundo. Estar com o mundo resulta de sua abertura à realidade, que o faz ser o ente de relações que é. (FREIRE, 1967, p. 39). Grifos do autor.

Consideramos de extrema importância que esta perspectiva educacional seja esclarecida para o aluno ao longo de sua formação em forma de tomada de consciência. É facilmente perceptível, na prática docente, que a execução do currículo prescrito vigente não oportuniza um ambiente educacional com este caráter humano. Ainda é escassa a busca pela tomada de consciência em relação à realidade objetiva e ainda permanecem as prescrições verticais desligadas dessa realidade, reproduzidas pelos professores.

Assim, Paulo Freire, dentre outros autores da América Latina, é um exemplo nacional de defensor dessa educação de caráter humano, estudado e utilizado por autores nacionais e internacionais da área da Educação, de um modo geral, bem como autores da área de Educação em Ciências e Educação em Química, pertencentes a diferentes linhas de pesquisas que, portanto, guardam perspectivas semelhantes.

A perspectiva de educação humanística, portanto, pode ser relacionada com perspectivas teóricas presentes nas linhas de pesquisa brasileiras de Educação Ambiental crítica (EAc); Ciência, Tecnologia e Sociedade (CTS); Natureza da Ciência/Nature Of Science (NOS); Alfabetização Científica (AC), Educação Popular (EP), dentre outras não citadas, como a perspectiva da Pedagogia Histórico-Crítica proposta por Demerval Saviani, e da perspectiva da Interculturalidade ${ }^{6}$. No entanto, como já apontado em capítulo anterior, consideramos a Teoria Histórico-Cultural, proposta por L. S. Vigotski e colaboradores, e a Teoria da Atividade, proposta por A. N. Leontiev e

\footnotetext{
${ }^{6}$ Exemplos de trabalhos na perspectiva intercultural da educação: Benite, Silva e Alvino (2016); Silva e Araújo (2015); Candau e Russo (2010); Canen (2000).
} 
colaboradores, como perspectivas de fundamentação teórica capazes de promover métodos de ensino e aprendizagem de conceitos científicos escolares efetivamente correspondentes à perspectiva humanística que buscamos, podendo, assim, contribuir teórico-metodologicamente com as limitações das referidas linhas de pesquisa, principalmente em relação ao processo de ensino e aprendizagem de conceitos científicos escolares da química.

Camillo (2015) traz contribuições para uma construção teórica própria do Ensino de Ciências em sua pesquisa no sentido da educação humanística, uma discussão que propõe alternativas às perspectivas individualistas de educação, considerando o desenvolvimento humano sob uma perspectiva sócio-histórico-cultural, relacionando contribuições do grupo de Vigotski e da perspectiva de Paulo Freire.

A partir de agora, serão rapidamente apontadas as principais ideias adotadas pelas linhas de pesquisa supracitadas, já parcialmente apresentadas no capítulo de Introdução, que fazem potenciais relações com a perspectiva de educação humanística que buscamos.

A Educação Ambiental crítica, cuja proposta educacional abrange todas as áreas do conhecimento e todos os níveis educacionais, salienta a atenção para uma educação efetivamente emancipatória e transformadora do sujeito e de sua realidade, e alerta para o cuidado com as interpretações ingênuas, apolíticas e acríticas da abordagem da Educação Ambiental direcionadas ao currículo escolar. Possui, segundo Loureiro (2006), perspectivas teóricas fundamentadas no método dialético marxista, cujas referências mais recorrentes estão representadas nos educadores Edgar Morin, Paulo Freire, Moacir Gadotti e Enrique Leff.

Uma das ideias centrais que corroboram com a busca por uma educação humanística é a de que, primeiramente, o homem não é um ser a parte da natureza, mas parte dela, dependente, que estabelece relações entre sujeitos que existem em sociedade, formando uma totalidade, logo, "o intercâmbio mutuamente constituído entre partes e todo não é exclusivamente orgânico, mas também socialmente ativo" (p. 99). 
A partir dessa ideia de não separação do homem, nem da natureza e nem da sociedade, a compreensão da realidade concreta deve permitir o entendimento dos movimentos dinâmicos e dialéticos que definem a vida, ao contrário de modelos exclusivamente cartesianos que buscam visualizar as relações apenas em suas formas abstratas e isoladas, apartando a ação dos sujeitos da história. A Educação Ambiental crítica busca uma educação transformadora que conscientize e promova atitudes de transformação da realidade concreta do sujeito em favor de uma relação sustentável entre homem e natureza, de modo que é necessário entender os efeitos do sistema de produção capitalista sobre o meio ambiente, ou seja, sobre a sociedade.

A Educação Popular na América Latina, entendida por Jara (2010) como um fenômeno sociocultural e uma concepção de educação, coloca a necessidade de humanizar o mundo, buscando formar as pessoas como agentes de mudança capazes de incidir nas relações econômicas, políticas, sociais e culturais como sujeitos de transformação, por meio de processos político-pedagógicos que buscam superar relações de dominação, opressão, desigualdade, exploração e exclusão, buscando construir relações equitativas e de igualdade de direitos entre as pessoas, configurando-se um novo paradigma educacional que confronta o modelo de educação autoritária, o qual dissocia a teoria da prática.

De acordo com Grossi (1984), a tarefa da educação popular é desenvolver a consciência dos sujeitos a respeito das reais causas dos problemas enfrentados por eles, fornecendo-lhes, em práticas concretas e socialmente situadas, instrumentos que os permitam ter uma compreensão cada vez mais precisa de sua situação social e histórica, a fim de mobilizá-los a iniciar a transformação destas. Paulo Freire chama a atenção para 0 reconhecimento da educação como práxis e do educando como sujeito de sua práxis. Sujeito no sentido ativo da palavra, aquele que fez e faz a sua própria história e a da sociedade, mas foi, em menor ou maior grau, privado das mesmas, seja por um sistema de relações de trabalho alienante, seja por um sistema educacional alienante, como afirma:

(...) se pretendemos a libertação dos homens, não podemos começar por aliená-los ou mantê-los alienados. A libertação autêntica, que é a humanização em processo, não é uma coisa que se deposita nos 
homens. Não é uma palavra a mais, oca, mitificante. É práxis, que implica na ação e na reflexão dos homens sobre o mundo para transformá-lo (FREIRE, 1987).

Podemos afirmar que, em certas frentes da Educação Popular, como a Educação no Campo e a Educação Indígena, por terem surgido em meio a opressões diretas aos sujeitos envolvidos, a perspectiva da educação humanística tenha se concretizado como práxis, já que os sujeitos convivem diariamente e diretamente com situações de exclusão e opressão, buscando superá-las com a ajuda do conhecimento (MOLINA, 2014).

A alfabetização/letramento/enculturação científica, entendida por esta pesquisa como um conjunto de concepções para a educação científica e que guardam intenções em comum, tem propósitos e abordagens teóricas que se relacionam com perspectivas da educação humanística, sob diferentes formas, conforme o sentido correspondente ao termo utilizado pelos autores. Sasseron e Carvalho (2008) tomam o termo alfabetização científica com base na ideia de alfabetização de Paulo Freire (1980), pela qual, mais que o domínio psicológico e mecânico, consciente, de técnicas de ler e escrever, a alfabetização implica numa autoformação que possibilite "uma postura interferente do homem sobre seu contexto".

Sob a perspectiva freireana, o sentido de o homem interferir sobre seu contexto implica em uma tomada de consciência de sua relação com o mundo e sua função social, logo, da importância de seu trabalho e demais contribuições para a sociedade, ou seja, do reconhecimento dessa importância, para que o mova a buscar mais conhecimento e a reivindicação de direitos que Ihes são ocultados.

Chassot (2003) toma a alfabetização científica a partir da concepção de ciência como uma linguagem, sendo a apropriação dessa linguagem, pelo sujeito, um meio facilitador da leitura do mundo em que vive e um meio que possibilita o sujeito a entender as necessidades de transformar esse mundo. $O$ entendimento da ciência, ou de uma das dimensões da ciência como linguagem, implica numa perspectiva de linguagem na qual a língua está a serviço de um poder (BARTHES, 1996 apud CHASSOT, 2003), unida à perspectiva do conhecimento científico como uma "instância privilegiada de 
relações de poder" (CHASSOT, 2003, p.96), pois esta união faz com que o conhecimento científico seja subjetivamente imposto como verdade definitiva por meio de uma linguagem acadêmica enviesada, ou seja, além de a linguagem científica não ser acessível a todos, faz-se manipuladora a serviço de um poder, exerce dominação intelectual e, consequentemente, política, econômica e social. Ao contrário, é necessário que a Alfabetização Científica contribua para que os sujeitos e os cidadãos não sejam submetidos, oprimidos e excluídos por esse poder.

Autores da linha CTS, pertencentes à perspectiva crítica, especificamente na América Latina, que possui uma realidade social, política e econômica diferente dos EUA e dos países europeus que adotam a linha CTS, tomam, em sua maioria, como referencial, os pressupostos educacionais de Paulo Freire. Santos (2002) e Santos e Mortimer (2009) adotam a perspectiva humanística a partir de diálogos com Paulo Freire para o estudo das interações discursivas na abordagem de aspectos sociocientíficos. De acordo com estes autores, uma educação humanística deve incorporar ao currículo a discussão de valores e reflexões críticas que possibilitem desvelar a realidade e a condição humana. Enfatizam a necessidade de ressignificação da função social do ensino de ciências com o desenvolvimento de atitudes e valores dentro dessa perspectiva, o que implica em uma postura dialógica do professor em sala de aula (MORTIMER e SCOTT, 2002).

Auler (2003) e Auler e Delizoicov (2001, 2006) aproximam o movimento CTS e a concepção educacional de Paulo Freire como encaminhamento político-pedagógico para propiciar Alfabetização Científica e Tecnológica, em correspondência com a concepção de Alfabetização freireana associada a uma leitura crítica do mundo contemporâneo para a democratização dos processos decisórios. Uma leitura crítica de mundo implica em uma compreensão crítica sobre as relações CTS.

Destaca-se, na ideia de Paulo Freire, a necessidade da superação da "cultura do silêncio", caracterizada pela ausência de participação da sociedade nos processos decisórios, para a constituição de uma sociedade mais democrática, tomando por base uma concepção o processo de significação do 
conceito químico escolar e seus aspectos socioambientais, bem como a não neutralidade da ciência e tecnologia. Isso implica, na ideia de Paulo Freire, que a vocação ontológica do ser humano é em "ser mais", discutido também em Camillo (2015), ou seja, ser sujeito ativo, sujeito histórico, e não objeto, para que seja possível uma "reinvenção" da sociedade (aspas do autor). Assim, a superação da "cultura do silêncio" implica na superação do modelo de decisões tecnocráticas, ou seja, na democratização das decisões envolvendo ciência e tecnologia.

Teixeira (2003), faz uma relação entre a abordagem CTS e a Pedagogia Histórico-Crítica (SAVIANI, 1989), na qual aponta pontos de convergência entre elas, chamando a atenção para o caráter humano da educação na perspectiva da segunda abordagem, que compreende a educação no contexto da sociedade humana, sua organização e, consequentemente, a adoção de uma proposta pedagógica cujo compromisso seja a transformação da sociedade, de forma que a condição para que o conhecimento seja significativo é que ele esteja centrado nas condições materiais da existência humana.

Santos e Mortimer (2002), em uma discussão sobre pressupostos teóricos para currículos CTS no Brasil, trazem críticas de sociólogos e filósofos da ciência à ciência, como a crítica à fé no progresso de $\mathrm{F}$. Bernard e $\mathrm{M}$. Crommelinck; o mito da neutralidade científica de H. Japiassu, G. Fourez; a crítica à função ideológica de legitimação da dominação social cumprida pela ciência e a técnica de J. Habermas, dentre outros, projetando essas teorias críticas como fundamentos teóricos para o ensino de ciências com abordagem CTS, com o intuito de salientar uma abordagem crítica que, ao pensar em currículo, discuta concepções de cidadania, modelo de sociedade e desenvolvimento tecnológico, tendo em vista a situação socioeconômica e aspectos culturais do país.

A linha do ensino da Natureza da Ciência/Nature Of Science (NOS) possui autores que procuram contextualizar o ensino desta abordagem utilizando como recursos a história, a sociologia e a filosofia da ciência. (ALLCHIN, 2006). Segundo o autor, a sociologia da ciência nesta abordagem é focalizada em três tipos: a macrossociologia, representada pelas instituições 
científicas e estrutura social de comunicação entre pares, agências de financiamento etc.; a microssociologia, que consiste nas relações interpessoais de laboratório; e a sociologia cultural, que explora as relações entre a ideologia social e as ideias e métodos científicos, considerando que a cultura e os valores do cientista influenciam em suas ideias.

A crítica cai sobre certas atitudes que alguns cientistas tomaram em determinados momentos históricos e sua repercussão na sociedade. Apesar de não ser direta e explicitamente relacionada à crítica ao modo de produção cientificista e consumista que submete o homem às necessidades de mercado da ciência, está dentro da compreensão de que o entendimento da natureza da ciência é fundamental para que o aluno possa entender suas implicações sociais, como defendem Aikenhead (1985 e 1994); Layton, Davey e Jenkins (1986); Ramsey (1993); Solomon (1993) e Stiefel (1995), porém por meio de uma crítica mais direta às injustiças sociais resultantes do referido modo de produção.

As aproximações teóricas com a concepção de educação humanística, relacionam direta ou indiretamente todas as linhas anteriores, em sua maioria, por meio da base marxista. Sabemos que as mesmas possuem autores com abordagens mais neutras em relação às abordagens críticas, mas aqui tentamos esclarecer que a crítica social que desejamos que os alunos tomem consciência está relacionada com a crítica ao modo de produção do sistema mercadológico capitalista e suas consequências para o sistema educacional. A partir desta crítica, há, também, os objetivos de formação e as metodologias que delineiam um diálogo entre as linhas de pesquisa supracitadas.

Como alguns exemplos dessas relações, podemos citar Santos e Mortimer (2002), que colocam como objetivo principal da abordagem CTS a Alfabetização Científica, e como recurso para o entendimento das relações CTS a compreensão da Natureza da Ciência. Sasseron e Carvalho (2008) apresentam o entendimento das relações CTS e da Natureza da Ciência como elementos integrantes dos eixos centrais para promover a Alfabetização Científica. 
A Educação Ambiental crítica tem, dentre seus objetivos, para 0 entendimento das relações humanas relacionadas às causas de degradação ambiental, a compreensão das relações sociais que envolvem 0 desenvolvimento científico-tecnológico, industrialização, urbanização, crescimento populacional, dentre outros fatores (LOUREIRO, 2000; DIAS, 2004), semelhantemente às relações estudadas no movimento CTS/CTSA (SANTOS, 2011), salvo a maior abrangência de áreas do conhecimento presentes no movimento da Educação Ambiental até o momento.

As potenciais semelhanças teóricas, consequentemente, proporcionam potenciais semelhanças metodológicas de ensino e aprendizagem entre as linhas citadas, como o trabalho por meio de temas contemporâneos, o ensino por investigação, por resolução de problemas, por estudos do meio, estudos de caso, casos históricos, casos contemporâneos, júri simulado, jogos, dentre outros (ALLCHIN, 2013, DIAS, 2004, SANTOS e MORTIMER, 2002), com potencial para o desenvolvimento da educação humanística pretendida teoricamente.

Também possui potencial para o desenvolvimento de práticas de sala de aula com elementos que promovem a postura ativa do aluno, mas, se ausentando dos aspectos teóricos que apontam a necessidade da inclusão de problemas sociais reais nas atividades de sala de aula, as quais ainda permanecem acríticas ou apresentando problemas sociais discutidos superficialmente de maneira a não serem efetivamente conectados com conceitos científicos escolares, abordando-se, separadamente, a realidade objetiva e os conceitos teóricos, resultando no que estamos criticando desde o início do texto: o encapsulamento dos conhecimentos científicos aprendidos na escola, a descaracterização de sua função para o entendimento, pelo aluno, de sua realidade.

Outro fator que contribui para que a discussão dos problemas sociais não promova a educação humanística é a não inclusão do aluno como parte do problema, como sujeito que sofre as consequências, ou que se beneficia delas, e, por isso, a impossibilidade do entendimento de que ele é um potencial agente de mudanças sociais, e da consciência de suas possibilidades e 
limitações. A não conexão entre realidade objetiva e conceitos científicos escolares e a não inclusão do aluno como sujeito ativo de sua história e da história da humanidade esboçam a principal preocupação e busca desta pesquisa. Estas negativas podem sustentar uma formação ativa, mas não produtiva, ou seja, reprodutiva (VIGOTSKI, 2009, p. 156) ou até produtiva, porém com propósitos antagônicos à educação humanística.

Esta concepção de educação de caráter humano, quando discutida pela perspectiva da Teoria Histórico-Cultural da Atividade, permite-nos adentrar mais profundamente, em relação às metodologias mencionadas, nas condições psicológicas do funcionamento dos processos de aprendizagem de crianças, adolescentes e adultos, possibilitando um entendimento mais efetivo e completo das relações sociais da realidade objetiva, aqui também chamada de realidade concreta. Assim, o processo de aprendizagem deve ser entendido dentro do processo de humanização, desenvolvido na perspectiva sóciohistórico-cultural em atividade de práxis.

Vale ressaltar que a Teoria Histórico-Cultural e a Teoria da Atividade não são teorias distintas, de modo que alguns autores as referenciam como Teoria Sócio-Histórico-Cultural da Atividade (CAMILLO, 2015). A primeira foi formulada pelo grupo de psicólogos russos liderado por L. S. Vigotski, A. N. Leontiev e A. R. Luria, tendo como principal autor Vigotski. Após a separação geográfica do grupo, causada pela revolução russa, a parceria continuou e a segunda teoria se desenvolveu como desdobramento da primeira, pelo grupo liderado por Leontiev (TUNES e PRESTES, 2009). De acordo com Longarezi e Franco (2013, p. 77), a Teoria da Atividade consistiu em uma mudança de ênfase $^{7}$ da Teoria Histórico-Cultural, sendo que a abordagem da Atividade chegou ao grupo de Leontiev a partir de Vigotski. Portanto, ao nos referirmos a Vigotski, entenda-se Vigotski e colaboradores, e o mesmo se aplica a Leontiev. A Teoria Histórico-Cultural é construída sobre bases marxistas, principalmente a partir dos conceitos de dialética e materialidade histórica (GADOTTI, 1983).

\footnotetext{
${ }^{7}$ A principal unidade de análise deixa de ser linguagem e passa a ser a Atividade.
} 
Segundo Vigotski $(2007,2009)$, o desenvolvimento cognitivo, estimulado pela aprendizagem se processa na relação do sujeito com o meio físico e social, mediada por instrumentos e signos, em atividades dirigidas a objetivos definidos que adquirem um significado próprio em um sistema de comportamento social, de modo que

O caminho do objeto até a criança e desta até o objeto passa através de outra pessoa. Essa estrutura humana complexa é o produto de um processo de desenvolvimento profundamente enraizado nas ligações entre história individual e história social. (VIGOTSKI, 2007, p. 20).

Assim, o objeto ao qual a atenção é dirigida, carregado de conhecimento cultural construído sócio-histórico-culturalmente, não irá, por si só, fornecer este conhecimento, mas uma outra pessoa, direta ou indiretamente, por meio da fala, de livros, de imagens, ou de outros instrumentos, aproximará o sujeito desse conhecimento, de acordo com a sua cultura, socializando-a, sendo que, ao longo de toda a história individual, o processo de socialização do conhecimento de cada objeto se dá, em um movimento dialético, com idas e vindas, do meio social para o individual, como proposto por uma das teses de Vigotski conhecida por "Internalização das Funções Psicológicas Superiores" (2007, p. 51).

Vigotski (2007) afirma que as funções psicológicas superiores se originam da inter-relação entre indivíduos em um movimento de internalização do mundo social, em uma direção que parte do exterior do indivíduo (interpsicológico) para seu interior (intrapsicológico), processo mediado por instrumentos e signos histórico-culturais, sendo o principal mediador a linguagem. O desenvolvimento cognitivo ontológico do sujeito, de acordo com a teoria histórico cultural, ocorre por um constante processo de internalização de operações, dado por meio de reconstruções internas de operações que inicialmente eram externas, sendo que a transformação de um processo interpessoal num processo intrapessoal é o resultado de uma longa série de eventos ocorridos ao longo do desenvolvimento cognitivo.

Algumas funções são internalizadas mais facilmente, outras permanecem e se modificam como formas externas por um longo período de tempo e só adquirem o caráter de funções internas como resultado de um desenvolvimento prolongado, e algumas funções podem permanecer para 
sempre como processos externos. No entanto, é importante o entendimento de que o processo de internalização não é uma via de mão única, com mediação do externo para o interno, o que pode remeter à ideia de passividade do aprendiz.

Neste sentido, Camillo (2015, p. 105-108) chama a atenção para as apropriações dualistas deste processo, que acabam por separar o ambiente exterior e o interior da mente humana, desconsiderando a existência de uma dinâmica complexa entre apropriações e objetivações, o que implica em conclusões errôneas, como a ideia de passividade já mencionada, isto é, a ideia de que o conhecimento que transita entre 0 exterior e o interior do indivíduo é formado em etapa estática e isolada, para só, posteriormente, ser internalizado, sem considerar o movimento dialético de idas e vindas entre interior e exterior, ou ainda, de modo a enfatizar apenas a influência do meio social exterior, apontando até mesmo a suposta existência de um intelecto coletivo sugerido pela teoria.

Segundo Vigotski (2007, p. 58), “a internalização de formas culturais de comportamento envolve a reconstrução da atividade psicológica”, cujo processo consiste em um conjunto de transformações, sendo o "resultado de uma longa série de eventos ocorridos ao longo do desenvolvimento". Algumas funções psicológicas superiores levam mais tempo que outras para serem internalizadas definitivamente, outras podem permanecer como uma forma externa de atividade ou como signo externo, sem envolver reconstrução interna. É importante, portanto, que seja considerada a história individual do processo de internalização dentro da história social na qual é formado, e esta última, carregada de conhecimentos construídos ao longo da história da humanidade, para que não pensemos no desenvolvimento cognitivo e, consequentemente, na aprendizagem, apenas em um momento específico ou em momentos isolados.

Mais tarde, após o desenvolvimento da Teoria da Atividade pelo grupo liderado por Leontiev, P. Ya. Galperin realiza estudos que aprofundam o entendimento dos processos que explicam a internalização, formulando, em 1952, os fundamentos da Teoria de Formação por Etapas das Ações Mentais e 
dos Conceitos. Esta teoria se estrutura sob a base de conceitos da escola de Vigotski e Leontiev, tais como: a natureza histórico-cultural da psique humana, os estudos sob os pontos de vista da atividade, o princípio da unidade entre as formas externas (materiais) e internas (psíquicas) da atividade humana. Esta teoria tem como ideia fundamental que as ações mentais são objetivas por natureza e inicialmente realizam-se com apoio de objetos externos. Estes, na medida em que são manipulados socialmente, assimilam as ações no plano da linguagem externa, a qual é utilizada na comunicação com outras pessoas, e depois, individualmente, no plano interior, sendo a palavra o instrumento fundamental da interiorização. Os conceitos constituem o conjunto de ações e as relações entre elas, já que o conceito não existe efetivamente sem as ações que proporcionam seu papel, suas funções (NÚÑEZ, 2009; NÚÑEZ e OLIVEIRA, 2013).

Segundo Vigotski, a internalização de funções psicológicas superiores, como é o caso da formação de conceitos, além de se constituir como um processo histórico-cultural, é mediada por instrumentos e signos.

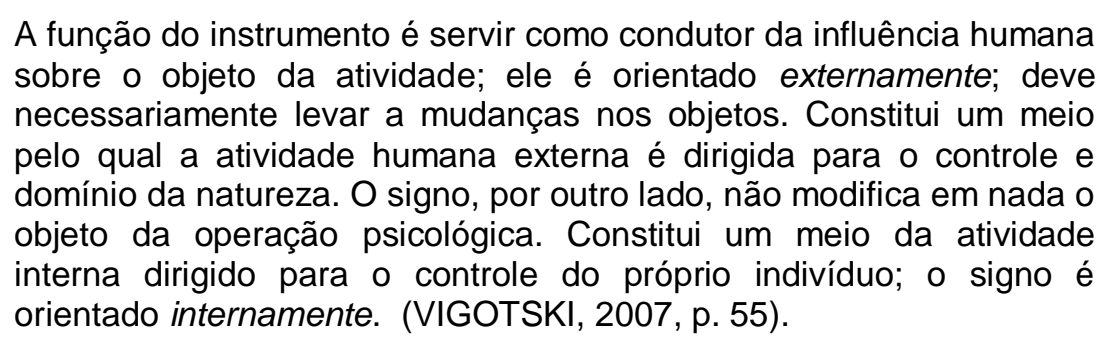

É importante entendermos, além da diferença entre instrumento e signo, o processo de modificação do objeto pelo instrumento. O objeto é o objeto de estudo, objeto de análise, que será modificado pelo instrumento, na medida em que este auxilia na compreensão das características e funções do objeto. Se o instrumento as possibilita com êxito, o objeto já não será mais visto como o era antes da compreensão, seu significado muda, logo, o objeto é modificado perante o sujeito que o compreendeu. Dessa forma, o instrumento modifica o objeto no sentido de auxílio de sua internalização. Como consequência, ao internalizar características e/ou funções desse objeto, o sujeito também é modificado internamente por meio da reconstrução da atividade psicológica em relação ao objeto. Nas palavras de Marx e Engels (1998), ao transformar a natureza, o homem também se transforma. 
Segundo a Teoria Histórico-Cultural, dentre todos os possíveis instrumentos, o principal deles é a linguagem. E, neste caso, o principal signo é a palavra. Para Vigotski, o papel da linguagem na constituição do sujeito é fundamental e o papel do outro em nossa constituição torna-se central. É na relação do sujeito com o meio físico e social que se processa o desenvolvimento cognitivo. Em relação ao meio social, Vigotski (1999, p.315) afirma: "É muito ingênuo interpretar o social apenas como coletivo, como existência de uma multiplicidade de pessoas. O social existe até onde há apenas um homem e suas emoções pessoais". O social também não pode ser entendido como separado da realidade concreta resultante do desenvolvimento humano, inerentemente histórico e cultural.

Esta pesquisa considera as interações discursivas de sala de aula os principais instrumentos, juntamente com as QSC envolvidas, os livros didáticos consultados pelos alunos, as tabelas com dados físico-químicos, dados reais de rendimento de motor de carros e de preços de combustíveis, retirados do INMETRO e de posto de combustíveis da cidade onde os alunos estudam. Nada afirmamos sobre os signos, apenas esperamos que os instrumentos sejam internalizados em alguma medida, assim como os conceitos.

No processo do movimento dialético do social ao individual se dá a apropriação de conceitos e significações, ou seja, se dá a apropriação da experiência social da humanidade. Na análise que Vigotski realiza entre pensamento e linguagem, a questão do significado ocupa lugar central. "O significado é um componente essencial da palavra e é, ao mesmo tempo, um ato de pensamento, pois o significado de uma palavra já é, em si, uma generalização". (OLIVEIRA, 2002, p. 48).

Vigotski distingue dois componentes do significado da palavra: "o significado propriamente dito, (refere-se ao sistema de relações objetivas que se formou no processo de desenvolvimento da palavra [...]compartilhado por todas as pessoas que a utilizam)"; e o "sentido, (refere-se ao significado da palavra para cada indivíduo, composto por relações que dizem respeito ao contexto de uso da palavra e às vivências afetivas do indivíduo". (OLIVEIRA, 2002, p. 50). 
Não seria prudente reduzir conceitos, como já fizemos com 0 instrumento, o signo, o significado e o sentido, a definições estáticas, já que estes se encontram em permanente movimento, mas para fins explicitativos, destacamos, aqui, uma das formas com as quais Vigotski expressa o conceito propriamente dito. Segundo o autor, o conceito

(...) é o reflexo objetivo das coisas em seus aspectos essenciais e diversos; forma-se como resultado da elaboração racional das representações, como resultado de ter descoberto os nexos e as relações desse objeto com outros, incluindo em si, portanto, um amplo processo de pensamento e conhecimento que, dir-se-ia, está concentrado nele [...] em sua faceta psicológica, é uma atividade prolongada que contém toda uma série de atos de pensamento. (1996, p.81).

A formação do conceito é pesquisada por Vigotski e colaboradores sob uma perspectiva ontológica, por meio da qual se busca entender desde os primeiros processos psicológicos infantis da gênese do conceito, percorrendo a adolescência e a idade adulta. (VIGOTSKI, 2009). Dentro desta perspectiva, é constatado que a análise da formação do conceito não deve ser realizada apenas por associações entre símbolos e entre objetos, ou a memorização de palavras.

O conceito não é tomado em seu sentido estático e isolado, mas nos processos vivos de pensamento, de solução do problema, de sorte que toda a investigação se divide numa série de etapas particulares, cada uma das quais incorpora os conceitos, nessa ou naquela aplicação aos processos de pensamento. (idem, p.165).

O processo de formação de conceitos é irredutível às associações, ao pensamento, à representação, ao juízo, às tendências determinantes, embora todas essas funções sejam participantes obrigatórias da síntese complexa que, em realidade, é o processo de formação de conceitos. Como mostra a investigação, a questão central desse processo é o emprego funcional do signo ou da palavra como meio através do qual o adolescente subordina ao seu poder as suas próprias operações psicológicas, através do qual ele domina o fluxo dos próprios processos psicológicos e lhes orienta a atividade no sentido de resolver os problemas que tem pela frente. (ibidem, p. 169)

Destacamos, nesses trechos, o conceito em movimento para a solução de um problema inserido dentro de uma atividade na qual o emprego funcional da palavra (conceito) a orienta. Aqui, o problema vem a ser solucionado por meio do uso do conceito como instrumento, que auxilia a solução do problema. 
Percebemos, no segundo trecho, alguns elementos indicativos do conceito de Atividade, que foi desenvolvido mais tarde por Leontiev. A Atividade que contém o problema a ser solucionado. Outros trechos de Vigotski (2009) fornecem mais apontamentos dos elementos envolvidos na situaçãoproblema, que servem de base para a Teoria da Atividade, como: "a colocação do problema e o surgimento da necessidade de formação do conceito [...] podem desencadear, mas não assegurar o processo de solução de uma dada tarefa." (p. 170).

\begin{abstract}
O caráter da tarefa, o objetivo que o adolescente tem diante de si e pode atingir através da formação de conceitos é, sem dúvida, um dos momentos funcionais sem cuja incorporação não poderemos explicar plena e cientificamente a formação do conceito. É precisamente com o auxílio dos problemas propostos, da necessidade que surge e é estimulada, dos objetivos colocados perante o adolescente que 0 meio social circundante o motiva e o leva a dar esse passo decisivo no desenvolvimento do seu pensamento (idem, p. 171).
\end{abstract}

Ao contrário do amadurecimento dos instintos e das atrações inatas, a força motivadora que determina o desencadeamento do processo, aciona qualquer mecanismo de amadurecimento do comportamento e o impulsiona para frente pela via do ulterior desenvolvimento não está radicada dentro, mas fora do adolescente e, neste sentido, os problemas que o meio social coloca diante do adolescente em processo de amadurecimento e estão vinculados à projeção desse adolescente na vida cultural, profissional e social dos adultos são, efetivamente, momentos funcionais sumamente importantes que tornam a reiterar o intercondicionamento, a conexão orgânica e a unidade interna entre os momentos de conteúdo e da forma do desenvolvimento do pensamento (ibidem, p. 171).

Percebemos, nestes trechos, além da indicação da importância da situação-problema para o processo de formação do conceito, a "necessidade" da formação do conceito para a resolução do problema, da "força motivadora" que estimula a satisfação dessa necessidade e desencadeia o processo rumo ao que Leontiev denomina objetivação, que trataremos adiante. Estes termos consistem em elementos centrais para a estruturação da Teoria da Atividade.

A referência ao adolescente e ao meio social externo a ele ser a fonte motivadora para desencadear o processo de resolução do problema e, consequentemente, o processo de formação de conceitos, é importante para esta pesquisa, que tem adolescentes como sujeitos e a intenção de incorporação de aspectos sociais da realidade concreta, como problemas sociais relacionados a aspectos sociocientíficos com implicações na vida desses sujeitos, para motivar a necessidade da formação de conceitos. $O$ meio 
social como fonte motivadora está relacionado ao que Leontiev denomina Atividade principal, que trataremos adiante.

Finalmente, a Teoria da Atividade vem desenvolver e estruturar os apontamentos conclusivos das pesquisas de Vigotski, alguns deles já discutidos, focando a Atividade que compõe os processos de ensino e aprendizagem, partindo-se da Atividade humana, e não desconsiderando a linguagem como principal instrumento mediador da Atividade, bem como sua unidade com o desenvolvimento psíquico do sujeito. (DAVIDOV e MARCOVA, 1987).

Segundo Leontiev (2012), "Não chamamos todos os processos de atividade. Por esse termo, designamos apenas aqueles processos que, realizando as relações do homem com o mundo, satisfazem uma necessidade especial correspondente a ele" (p. 68). A atividade humana, segundo Leontiev (1978), é produtiva e criadora. Surge em função de uma necessidade, é mantida por um motivo e dirigida a um objeto. $O$ objeto da atividade é seu motivo real, ou seja, o motivo deve coincidir com o objeto. O objeto pode ser material ou ideal, ou seja, pode estar tanto no meio externo quanto no plano das ideias. O importante é que para além do objeto está a necessidade. Dessa forma, atividade e motivo estão necessariamente relacionados. A atividade tem como componentes estruturais as ações pelas quais é realizada. A ação é um processo que se subordina à representação do resultado a ser alcançado, ou seja, "um processo subordinado a um objetivo consciente" (LEONTIEV, 1983, p. 83).

Assim como a Atividade se relaciona com o motivo, a ação se relaciona com o objetivo, pois a ação é um desdobramento das funções que estavam no motivo. Por exemplo, se temos necessidade de nos alimentarmos, tendo a fome como motivo, podemos realizar ações que não satisfaçam diretamente a necessidade (idem, p. 84), como lavar uma panela. As formas de realização da ação são denominadas operações. Componentes geradores da ação relacionadas às condições, de modo que pode ocorrer do objetivo da ação permanecer o mesmo, mas as condições da ação variarem, alterando o aspecto operacional da ação. (ibidem, p. 87). 
Em suas pesquisas, Leontiev (2012) busca entender as forças motivadoras do desenvolvimento da psique infantil. Estabelece, como um primeiro ponto, que o lugar ocupado pela criança nos sistemas de relações humanas se altera ao longo de seu desenvolvimento sob condições concretas de vida. Demonstra-o por meio de uma descrição dos estágios de desenvolvimento da criança: a infância pré-escolar, escolar infantil, escolar adolescente. Propõe que o desenvolvimento da psique infantil tem como principal fator determinante o desenvolvimento de sua atividade, em cada estágio, o qual depende de suas condições de vida. O lugar que a criança ocupa em cada fase desse desenvolvimento apenas caracteriza o estágio alcançado. É preciso, portanto, a análise do conteúdo da atividade infantil em desenvolvimento para compreender o papel condutor da educação, operando em sua atividade e em sua atitude diante da realidade (p. 63).

Para esta pesquisa, focalizamos o estudo da dependência do desenvolvimento psíquico em relação às atividades principais, caracterizando as atividades principais como a atividade cujo desenvolvimento governa as mudanças mais importantes nos processos psíquicos da criança.

O adolescente está saindo de uma fase infantil acrítica, de cobranças, exigências, regras, e passando para uma fase de crescimento de uma atividade crítica sobre tais cobranças por meio da crítica ao comportamento e às qualidades dos adultos. $\mathrm{Na}$ escola, surge a necessidade de expandir $\mathrm{O}$ conhecimento sobre a realidade, ultrapassando os limites da realidade que o cerca, fazendo com que sinta a necessidade de saber também sobre o que é conhecido acerca dessa realidade (idem, p. 62 e 63).

Explica a mudança da atividade principal durante o desenvolvimento infantil por meio de um processo em que o motivo da atividade passa para 0 objeto da ação, fazendo com que a ação se transforme em uma atividade, sendo esta a maneira pela qual surgem todas as novas atividades e novas relações com a realidade e sendo esta a base psicológica concreta sobre a qual ocorrem mudanças na atividade principal e, consequentemente, as transições de um estágio de desenvolvimento para o outro. Dessa forma, a atividade da criança em idade pré-escolar e escolar infantil é a brincadeira. 
Durante a fase escolar passa a ser o estudo e, na fase escolar adolescente, além da atividade de estudo, surge a atividade de intensificação e ampliação da socialização. (LEONTIEV, 2012)

A implicação da existência de atividades principais correspondentes aos estágios de desenvolvimento é que a escola deve levá-las em conta no planejamento das atividades de ensino. No entanto, sabemos que o que ainda ocorre no sistema educacional é a supressão de certas atividades principais, como, por exemplo, a necessidade de socialização do adolescente e a convivência em grupos é suprimida pela exigência de carteiras enfileiradas e ausência de conversas nos momentos de ensino e aprendizagem, dificultando o desenvolvimento das potencialidades do aluno na socialização do conhecimento.

O entendimento de Leontiev de que a atividade principal da criança na idade escolar é o estudo, porém, considerando a realidade brasileira do ensino na rede pública, esse entendimento necessita ser problematizado, pois essa constatação refere-se às crianças russas. A Teoria Histórico-Cultural, por meio do caráter sócio-histórico-cultural no qual se dá o desenvolvimento do sujeito, nos dá base para não generalizarmos a atividade de estudo como uma atividade espontânea como o brincar, mas atividade esperada pela cultura social da qual faz parte, preparada e direcionada intencionalmente pelo professor. Estas fases ou estágios de desenvolvimento não devem ser tomadas a cabo, ou entendidas de maneira linear. Assim como no estudo experimental do desenvolvimento dos conceitos, descrito em Vigotski (2009), os estágios de desenvolvimento dos conceitos não estão rigidamente vinculados a faixas etárias. Entendemos, ao relacionar os estudos desses autores, que se torna necessário considerar, no ensino e aprendizagem escolar, o desenvolvimento de conceitos científicos não só por meio das atividades principais, mas também por meio da complexidade da realidade histórico-cultural do sujeito.

A atividade de estudo também é diferenciada do termo "atividade" que venha a designar um trabalho qualquer, isolado, realizado pelo aluno. Diferente deste, a atividade de estudo integral é considerada em sua unidade com o 
desenvolvimento da psique do aprendiz, e pelo processo de aprimoramento da inter-relação entre seus componentes: a compreensão das tarefas de estudo, a realização das ações de estudo e a realização das ações de controle e autoavaliação pelo aluno. A atividade de estudo ou atividade de estudo integral não tem um fim em si mesma, mas cria uma condição crucial para o desenvolvimento intelectual, moral e motivacional do aluno, de modo a desenvolver autonomia pela busca de conhecimento e mudança de atitude social e pessoal, resultando em influências para o desenvolvimento de sua personalidade. A atividade de estudo deve ter um sentido pessoal, para que se torne a atividade principal e resulte no desenvolvimento da autoformação, autoavaliação, automotivação e influencie o desenvolvimento psicológico de transformações de outras atividades para além da atividade de estudo, de maneira enriquecedora para a vida do aluno e para a vida de quem possa influenciar em suas relações sociais. (DAVIDOV e MARCOVA, 1987).

Acreditamos que esta concepção de atividade de estudo corrobora a complementar propostas metodológicas para um ensino de ciências dentro da concepção humanística de educação se devidamente localizada e contextualizada aos problemas sociais característicos do Brasil e na relação destes com os problemas globais. No caso desta pesquisa, abordamos problemas sociais brasileiros.

A formação de conceitos ganha novos elementos metodológicos, além daqueles já elaborados anteriormente por Vigotski. O estudo dos conceitos em sala de aula parte da introdução do conceito por meio da reprodução da necessidade lógico-histórica de sua criação, de modo que haja a reprodução da atividade que proporcionou a criação do conceito, reproduzindo-se, portanto, a necessidade, o motivo, e o conceito como objeto (LEONTIEV, 1978).

A reprodução da necessidade lógico-histórica não exige que o processo histórico original seja reproduzido com os alunos, sendo esta via uma opção (MOURA e COLABORADORAS, 2010). O importante é que o problema proposto reproduza a necessidade de sistematização e apropriação do conceito. Esta lógica metodológica pode ser encontrada no trabalho de Moura 
e Lanner de Moura (1998) com a abordagem de jogos, situações emergentes do cotidiano e histórias virtuais.

A sistematização do conceito é um ponto delicado no sentido de que, apesar de estar inserido em meio a uma atividade, pode ser transmitido pelo professor de modo a abordar apenas a aparência externa do conceito, ainda mais se esta for suficiente para solucionar o problema, resultando em uma aproximação superficial do aluno ao conceito. Esta também é uma preocupação da presente pesquisa. Em relação a isso, faz-se necessário que, ao propiciar aos alunos o conhecimento lógico-histórico do conceito, também seja possibilitado o desenvolvendo do pensamento teórico correspondente, superando a aparência externa dos objetos (conceitos) para compreensão da sua essência e de suas relações internas, o que é possível na medida em que o professor proporcione para os alunos o método teórico geral (DAVÍDOV e MÁRCOVA, 1987; RUBTSOV, 1996). Segundo este, a atividade de aprendizagem passa por uma atividade concreta, porém só é atividade de aprendizagem se os processos de aquisição do conteúdo forem o objetivo direto e o problema a ser resolvido pela atividade. E é importante que a aquisição dos conteúdos seja a aquisição de um método teórico geral/generalista, cuja aplicação solucione da mesma forma todas as variantes concretas do problema de aprendizagem.

V. V. Davídov (1930-1998), incialmente aluno e, posteriormente, colaborador de Leontiev, Galperin, dentre outros, elaborou, na década de 1970, a Teoria do Ensino Desenvolvimental, com origem baseada na ideia de Vigotski de que "na base do desenvolvimento intelectual das crianças está o conteúdo dos conhecimentos assimilados" (DAVÍDOV, 1996 apud LIBÂNEO e FREITAS, 2013, p. 321). Também estabeleceram que a aprendizagem de conceitos antecede o desenvolvimento psíquico, valorizando a educação escolar como o principal potencializador desse desenvolvimento, articulando questões sobre o método de pensamento do abstrato ao concreto, de Ylyénkov; com a teoria da atividade e com o tema da generalização concernente à aprendizagem. De acordo Libâneo e Freitas (2013), Davídov indica a forma de estruturação da atividade de estudo dos alunos por um caminho que os leva a formar o pensamento teórico. Para isso, o professor 
apresenta aos alunos tarefas de solução de problemas que os coloca no processo de busca das condições de origem do objeto, pelo movimento do abstrato ao concreto. Neste movimento, é necessário que os alunos identifiquem o "núcleo" do objeto, correspondente ao aspecto mais geral que o caracteriza e, com base neste núcleo, sejam capazes de deduzir as relações particulares do objeto de estudo. Em síntese, a análise das relações genéticas constitutivas do objeto de estudo, conduz o aluno à compreensão, primeiramente, da essência deste objeto, não somente de sua aparência externa (conhecimento empírico), para depois formar mentalmente o objeto e as ações mentais que correspondem ao modo de pensá-lo, de investigá-lo e de descobrir as conexões entre a essência e a aparência, ou seja, formar o conhecimento teórico que leva ao pensamento teórico (p. 338, 339).

Assim, percebemos a importância e responsabilidade do trabalho do professor e as implicações para o planejamento de atividades de ensino e aprendizagem, que partem da realidade concreta do aluno e se dirigem até as ações mentais previstas para o desenvolvimento do pensamento teórico por meio do desenvolvimento do método teórico geral do conceito. Em função dessas demandas específicas do professor, Moura e colaboradoras (2010) propõem a Atividade Orientadora de Ensino (AOE) para a organização planejada da atividade de ensino unida à atividade de aprendizagem. A AOE considera a atividade de aprendizagem no sentido de decorrer de uma atividade de ensino escolar, intencional, sistematizada e organizada com o objetivo de formação do pensamento teórico. A atividade de ensino, por sua vez, é a atividade principal do professor, diretamente relacionada com seu trabalho. Seu planejamento, aplicação, avaliação e reelaboração contribuem para a reflexão e aprimoramento de seu trabalho e desenvolvimento psíquico, significando a atividade pedagógica como um objetivo pessoal e social. A mediação do professor consiste em uma aproximação constante do aluno ao conceito e implica em mediar a relação entre teoria e prática, ação e reflexão.

A atividade de aprendizagem parte do concreto e deve objetivar 0 desenvolvimento do pensamento teórico. $\mathrm{Na}$ presente pesquisa, nos preocupamos que o objetivo principal da atividade de aprendizagem do aluno seja a complexificação do entendimento sobre sua realidade, o que só se 
concretiza com o desenvolvimento do pensamento teórico, elaborado, no nosso caso, com a ajuda da apropriação dos conceitos da química, na tentativa de que os conceitos não tenham um fim em si mesmos. Dessa forma, consideramos que o movimento da atividade de aprendizagem deva buscar seu ponto de partida na realidade concreta, seu ponto de aprofundamento em conhecimentos teóricos da química, e seu ponto de chegada seja a mesma realidade concreta, complexificada, no pensamento do aluno, pela união entre a malha de conceitos e suas relações com a realidade. Nas palavras de Camillo e Mattos (2014) apud Ylyenov (2004), encontramos a seguinte referência a este movimento:

\begin{abstract}
$\mathrm{Na}$ perspectiva do materialismo dialético, a construção do conhecimento se dá pelo contínuo movimento de redução do concreto imediato ao abstrato e ascensão ao concreto real, complexificado. O concreto passa a ser entendido, sob essa lógica, o início e o fim de todo o processo, mediado por um elo intermediário de abstração, visto como uma redução, uma vez que isola elementos do concreto primitivo (sensório) para transformá-los por meio da atividade da práxis. A verdadeira ascensão reside na volta ao concreto real, qualitativamente diferente do primeiro concreto (sensório), no qual se fazem presentes toda a complexidade e as contradições inerentes à realidade humana (CAMILLO e MATTOS, 2014, p. 218).
\end{abstract}

Dessa forma, continuam os autores, a formação de conceitos consiste em "articulações cada vez mais complexas com o mundo real" (idem, p.218).

De acordo com Davídov (1988 d) apud Libâneo e Freitas (2013), o pensamento teórico tem o concreto como ponto de partida da contemplação e representação, e como resultado mental da reunião das abstrações. A partir desse ponto de vista, entendemos que a complexificação da realidade que estamos nos referindo é mental, depende dos conceitos teóricos e se dá pelo próprio processo de desenvolvimento do pensamento teórico.

Acreditamos que questões sociocientíficas reais contribuam como ponto de partida (concreto sensório) e de chegada (concreto complexificado) para este movimento de redução do concreto imediato, abstração e ascensão ao concreto complexificado, mantendo a motivação da atividade de estudo, justamente por trazerem aspectos reais e controversos que fazem sentido para o aluno por pertencerem a sua realidade imediata, sócio-histórica-cultural, vinculando, assim, conhecimento teórico a esta realidade. 


\subsection{Conceitos teóricos focalizados nesta pesquisa}

Retomaremos, aqui, os conceitos da Teoria Histórico-Cultural da Atividade que fundamentaram a pesquisa, desde a preparação da aula aplicada à análise das interações discursivas, sendo esses conceitos. delineados anteriormente à análise das mesmas. O resultado desse delineamento permitiu, além de orientar as intenções da aula ${ }^{8}$ e sua aplicação, também reconhecer que a análise das relações entre os conceitos científicos escolares da química e os conceitos relacionados à temática socioambiental abordada na aula está imbricada, ou, é a própria análise da formação, construção dos conceitos envolvidos, visto que, se não considerarmos o objeto (conceitos da química) em unidade com determinada totalidade (contexto da temática socioambiental real), não tomaremos consciência das relações (ações) entre a essência e a aparência, entre conteúdo interno e externo, que fazem parte da formação do conceito em meio à atividade interna em unidade com a atividade externa (LEONTIEV, 1983).

A seguir, é apresentado o conjunto de conceitos teóricos que teceram tal conclusão, configurando as principais contribuições da Teoria Histórico-Cultural da Atividade que consideramos para este trabalho, em relação aos processos envolvidos no modo em como se dá a apropriação de conceitos.

\subsubsection{O contexto}

Para fundamentar o conceito de contexto adotado nesta pesquisa, recorremos à discussão feita por Lacasa (1994), na qual teorias contextuais e teorias contextualizadoras são diferidas por dois exemplos de questão de pesquisa originados nos estudos da psicologia da educação. Primeira questão: "Quais são os mecanismos através dos quais as crianças chegam à construção dos conhecimentos compartilhados em aula?". Segunda questão: "Em que medida as situações de grupo facilitam a construção do conhecimento?" (tradução nossa, p. 5).

\footnotetext{
${ }^{8}$ Aula aplicada aos alunos do projeto CIMEAC para coletar os dados a serem analisados nesta pesquisa.
} 
A primeira questão é formada a partir de uma teoria contextual, em cujos princípios é aceito que a construção do conhecimento é um processo que transcende os limites do indivíduo, cujas raízes partem do entorno. O social e o cognitivo, no caso da primeira questão, são dimensões de um único processo. Já a segunda questão é formada a partir de uma teoria contextualizadora, na qual o contexto é uma variável independente que incide na conduta do indivíduo. A construção do conceito é uma tarefa individual, sendo necessário precisar, dentre os efeitos do contexto, quais variáveis podem incidir no processo (idem, 1994).

De acordo com Lacasa (1994), as linhas de investigação, derivadas da perspectiva vigotskiana, correspondem às teorias contextuais. Já as teorias contextualizadoras tem origem nos estudos de Piaget em relação ao processamento da informação.

Considerar uma ou outra das teorias acima traz implicações a toda estrutura da pesquisa, desde os planejamentos iniciais até as conclusões. Dessa forma, esclarecemos que a presente pesquisa procurou, do planejamento às conclusões, fundamentar as propostas adotadas desde 0 ensino de ciências na perspectiva teórica vigotskiana. Assim, sujeito e contexto social (realidade concreta), processos cognitivos e contexto social são concebidos como dimensões de um mesmo processo.

\subsubsection{Significado de conceito}

Como pressuposto inicial, esta pesquisa considera como conceito um objeto de estudo cujo processo de formação tem início, porém não tem fim. Não tem fim no sentido de que não se limita a uma determinada definição lógica, já que as próprias definições lógicas das ciências passam por mudanças ao longo da história.

O conceito consiste em um conjunto dinâmico de atributos e seus respectivos significados em constantes relações de contexto e entre contextos, sendo estas relações as ações da atividade humana na qual presta o seu papel. Sua definição deve ser o produto, não o início, de seu processo de formação. E mesmo que a definição do conceito seja um produto, só pode ser 
chamada de produto final dentro de um determinado contexto, pois enquanto houver novos contextos, haverá novas definições, modificando as anteriores e, por sua vez, modificando o conceito, complexificando-o ao longo da vida do sujeito.

Assim, concordamos com o princípio colocado por Galperin, apoiado no princípio da unidade entre consciência e atividade humana, de Leontiev, de que o processo de formação de um conceito não pode ser alcançado sem vinculá-lo às ações da atividade, ações mentais adequadas aos conceitos, de maneira que o aluno se aproprie não somente do conteúdo em si, mas das ações que o objetivam. Consideramos que o conceito, sem a ação que o funcionaliza, é um conceito apartado da realidade concreta. Segundo Galperin, Zaporozhets e Elkonin (1987, p. 304) apud Núñez e Oliveira (2013, p. 298), "O conhecimento sobre as coisas se forma como resultado das ações com essas coisas".

Um conceito apartado de sua realidade concreta consiste em um conceito abstrato. Segundo Davídov (1988, p. 150,151), o caráter concreto ou abstrato do conhecimento refere-se à dependência com determinada totalidade. Assim, no conhecimento abstrato o objeto ou fenômeno é examinado independentemente do todo, sendo isolado e autônomo, por mais concretos que sejam seus exemplos ilustrativos. Ao contrário, para que o conhecimento seja concreto, o fenômeno ou objeto (conceito) é necessariamente examinado em unidade com o todo, em relação com outras manifestações, com sua essência, mesmo que seja expresso por meio de símbolos abstratos.

Não negamos os conceitos abstratos. Eles fazem parte do processo de formação de conceitos, sendo um estágio deste. O problema que pretendemos superar é o de que permaneçam abstratos. Segundo Davídov e Márcova (1987), os conceitos abstratos situam-se no caráter verbal, racionalista e discursivo.

Vale lembrar que, de acordo com o referencial histórico-cultural, o caráter abstrato do conhecimento é diferente do caráter teórico. 0 conhecimento teórico é aquele que representa as inter-relações entre essência 
e aparência do objeto (conceito) a ser apropriado, entre conteúdo interno e externo, entre o original e o derivado (DAVYDOV, 1999, p. 126 apud LIBÂNEO e FREITAS, p. 337). É formado a partir da análise do papel da função que cumpre certa relação entre as coisas dentro do sistema. Sua base é a transformação dos objetos por refletir suas relações e enlaces internos. Durante a representação do objeto em forma de conhecimento teórico, o pensamento supera os limites das representações sensoriais, levando ao pensamento teórico (DAVÍDOV e MÁRCOVA (1987), sendo o principal objetivo do processo de formação de conceitos, segundo Davídov, desenvolver o conhecimento teórico que leva ao pensamento teórico. Acreditamos que o conceito de caráter teórico e de caráter concreto se aproxima com o que Vigotski (2009) denomina de conceito superior.

Outra forma de conhecimento antagônica ao conhecimento teórico é o conhecimento empírico, que leva à formação do pensamento empírico. 0 caráter empírico é formado a partir da comparação dos objetos e suas representações, com separação das propriedades semelhantes e gerais. Sua base é a observação que reflete somente as propriedades externas dos objetos, apoiando-se totalmente nas representações visuais, representando somente a aparência dos objetos (DAVÍDOV e MÁRCOVA (1987).

Assim, concordamos com estes princípios de Galperin (unidade entre conceito e ações da atividade) e Davídov (a busca pela formação do pensamento teórico) em relação à formação dos conceitos; no entanto, diferentemente do contexto das publicações dos estudos realizados pelos autores, o qual se debruça sobre a educação primária infantil, nosso trabalho foi realizado com o público do ensino médio. Não utilizamos uma base material para o objeto de estudo como Galperin. Abordamos o objeto de estudo e seu sistema a partir do plano verbal e simbólico, em busca do plano mental. Não utilizamos a sequência que Davídov propõe, iniciada pela identificação da relação universal, característica mais geral, ou base genética do conceito pelo aluno, para depois os mesmos realizarem tarefas particulares e singulares. Ao contrário, iniciamos com situações-problema particulares, e conforme o aluno necessita dos conceitos e suas ações, a professora os fornece, buscando construir, em conjunto com os alunos, a base teórica geral do conceito, dentro 
dos limites do contexto preparado para a aula. Nossa escolha para a fundamentação da preparação da sequência de atividades aplicadas em aula se fundamentou, principalmente, no caráter sócio-histórico da aprendizagem como atividade humana, seguindo a nossa interpretação do que já citamos no item anterior deste capítulo e retomaremos aqui, em relação ao que Vigotski (2009) coloca sobre a formação do conceito: “O conceito não é tomado em seu sentido estático e isolado, mas nos processos vivos de pensamento, de solução de problema" (p.165);

\begin{abstract}
O caráter da tarefa, o objetivo que o adolescente tem diante de si e pode atingir através da formação de conceitos é, sem dúvida, um dos momentos funcionais sem cuja incorporação não poderemos explicar plena e cientificamente a formação do conceito. É precisamente com o auxílio dos problemas propostos, da necessidade que surge e é estimulada, dos objetivos colocados perante o adolescente que 0 meio social circundante o motiva e o leva a dar esse passo decisivo no desenvolvimento do seu pensamento (p. 171).
\end{abstract}

Assim, objetivamos uma sequência de atividades na qual a necessidade coincide com o objeto de estudo, gerando o motivo da ação direcionada à apropriação dos conceitos da química e da transformação da percepção sobre a realidade concreta, sendo a tomada de consciência dos conceitos e a tomada de consciência de situações da realidade concreta dimensões de um mesmo processo, uma em função da outra. A necessidade parte do contexto pertencente à realidade concreta (aparente) do aluno, que ao ser reduzida aos conceitos abstratos, por meio de ações que inter-relacionam a essência e a aparência desses conceitos, transforma os conceitos abstratos em teóricos e a realidade aparente em realidade concreta complexificada.

A sequência de atividades, composta por uma sequência de problemas, discussões temáticas e questões sobre vídeos, são permeadas por questões sociocientíficas (QSC) que guardam particularidades da realidade regional e nacional sobre as relações CTSA na produção de biocombustíveis e de alimentos, e do lugar ocupado pelo aluno diante desta realidade, e ainda, proporcionam a expansão da atividade inicial por meio de novas QSC, portadoras de controvérsias que motivam novas ações em busca de novos conceitos, ou exploram novas funções dos conceitos já abordados em outros contextos, esperando-se promover a interação entre conceitos espontâneos e científicos, entre sentido e significado dos conceitos, relações de generalidade 
entre os conceitos científicos, tomada de consciência dos problemas reais colocados e dos conceitos químicos envolvidos, por meio da reprodução histórico-social da atividade de análise crítica de problemas socioambientais reais envolvidos na produção e uso de combustíveis e alimentos pelo homem contemporâneo.

Em síntese, uma sequência de problemas (QSC), de caráter socioeconômico, socioambiental e político, com suas relações CTSA, formam uma grande atividade de análise crítica de problemas socioambientais que atingem direta ou indiretamente a vida dos alunos. Esta análise crítica é inicialmente motivada por uma proposta hipotética de levantamento de critérios para a escolha de um carro pelos alunos.

Dessa forma, consideramos o contexto dos conceitos termoquímicos a serem apropriados como a totalidade que vai desde o sistema de conceitos químicos no qual os termoquímicos estão inseridos até os limites das discussões sobre a realidade concreta na qual as QSC estão inseridas.

Retomando a compreensão do significado de conceito, necessitamos ainda dizer que ela traz implicações fundamentais para a compreensão do processo de ensino e aprendizagem, permitindo reconhecer, por meio da nossa experiência profissional docente, no ensino de química atual, a presença de uma ênfase ainda centrada na transmissão de uma única definição do conceito em um único contexto, dentro da perspectiva de uma única disciplina escolar, ou, diferentes definições para um mesmo conceito, concernentes a diferentes disciplinas, sendo que tais conceitos permanecem sem a abordagem das possíveis relações internas e externas, e entre contextos, esperando-se que o aluno as faça por si próprio ${ }^{9}$, ou, esta elaboração de relações nem é cogitada.

A abordagem do conceito, nesta perspectiva, é, portanto, estática e isolada a um único objeto, o que dificulta o processo de construção do

\footnotetext{
${ }^{9}$ Para elaborações próprias/individuais do aprendiz, ver conceito de Zona de Desenvolvimento Proximal (ZDP) na obra "A formação social da mente" (VIGOTSKI, 2007), pelo qual fica claro que as elaborações individuais do aprendiz são possíveis a partir do que ele já tem internalizado. Novas elaborações são possíveis por meio das interações com, e mediações de, outrem.
} 
conceito, e resulta apenas no desenvolvimento do conhecimento empírico ou abstrato.

\title{
3.2.3 Situação-Problema
}

Uma das observações iniciais feita por Vigotski, ao estudar a pesquisa de autores de sua época, em relação ao processo de formação de conceitos de crianças e adolescentes, mais especificamente em relação aos experimentos de Ach, aponta que:

A formação de conceitos é um processo de caráter produtivo e não reprodutivo, (...) um conceito surge e se configura no curso de uma operação complexa voltada para a solução de algum problema (...) só a presença de condições externas e o estabelecimento mecânico de uma ligação entre a palavra e o objeto não são suficientes para a criação de um conceito. (VIGOTSKI, 2009, p. 156)

A perspectiva vigotskiana traz contribuições para o educador que pretende elaborar aulas que prezem pela formação de conceitos em meio a um coletivo de aprendizes. Para esta pesquisa, a principal contribuição está na preparação de uma atividade que traga uma situação-problema ou uma série atividades que contenham situações-problema que ofereçam contextos, objetivos e motivos para que os alunos desenvolvam a necessidade de buscar, relacionar informações e, assim, iniciar a construção de novos conceitos, reelaborando aqueles já internalizados. Ou seja, partimos de "um problema que só possa ser resolvido pela formação de novos conceitos" (idem, p.157).

A noção de problema se associa aos conceitos de atividade, motivo e objetivo, desenvolvidos por Leontiev na Teoria da Atividade. Segundo Leontiev:

\begin{abstract}
Não chamamos todos os processos de atividade. Por esse termo designamos apenas aqueles processos que, realizando as relações do homem com o mundo, satisfazem uma necessidade especial correspondente a ele (...) Por atividade, designamos os processos psicológicos caracterizados por aquilo que o processo, como um todo, se dirige (seu objeto), coincidindo sempre com o objetivo que estimula o sujeito a executar esta atividade, isto é, o motivo. (LEONTIEV, 2012, p. 68)
\end{abstract}

Assim, a atividade como um todo, deve estar relacionada a um motivo, que leva seu sujeito a executar ações, as quais tem fins específicos e cujas condições chamam-se de operações. A situação-problema, seja em uma atividade de estudo (LEONTIEV, 2012; DAVIDOV e MARCOVA, 1987), seja em uma atividade de ensino e aprendizagem (RUBTSOV, 1996; MOURA e 
colaboradoras, 2010) ocupa uma posição na atividade de modo a requerer a ação que visa o objetivo a ser atingido.

Neste trabalho, considera-se o uso de situações-problema ${ }^{10}$ para a formação de conceitos, a fim de se trabalhar a aplicação do conceito em um contexto real e se evitar definições estáticas e isoladas dos conceitos, que se encerrem em uma suposta memorização. Não se nega, aqui, a definição, mas como já dito, entendemos que esta deve ser um produto de um processo de formação do conceito, não seu início. Mesmo assim, como resultado de um processo, ou de parte dele, faz sentido apenas para o contexto abordado no problema, e não fará sentido se o contexto não tiver relação com a realidade concreta do aprendiz. Ou seja, a imposição de um conceito que existe fora da realidade do aluno impede a produção do significado, logo, dificulta a formação do conceito.

Vigotski (2009) traz uma observação importante em relação ao ato de definição de conceitos dentro do funcionamento do pensamento do adolescente. Conclui, a partir de experimentos, que tanto o adolescente quanto o adulto formam e utilizam um conceito com muita propriedade numa situação concreta, mas tem dificuldades em definir o conceito. A definição verbal é muito mais limitada do que a utilização do conceito. A análise da realidade com a ajuda de conceitos precede a análise dos próprios conceitos (p. 230).

Assim, nesta pesquisa, considera-se a importância de as situaçõesproblema partirem da utilização do conceito em situações concretas, visando subverter a imposição de definições fora da realidade do aluno, em busca do processo de formação ativo do conhecimento concreto e teórico.

\subsubsection{Conceito científico e conceito espontâneo}

Por conceito científico, consideramos os conceitos elaborados pelos cientistas, dentro da comunidade científica, portanto, não acessível, em sua gênese, aos cidadãos que não fazem parte dessa comunidade. Sua

\footnotetext{
${ }^{10}$ As situações-problema (VIGOTSKI, 2009), são denominadas "situações desencadeadoras da Atividade por Moura e colaboradoras (2010) e denominadas "tarefas de estudo" (DAVIDOV, 1987, 1988, apud MOURA e COLABORADORAS, 2010)
} 
acessibilidade informacional se dá posteriormente a sua elaboração, principalmente pelos meios de comunicação e pela escola, sendo nesta, em diferentes níveis de ensino. Para isso, necessita ser adaptado às linguagens de destino e é neste processo em que nos localizamos como professores pesquisadores da educação em ciências.

Falamos em conceito científico escolar ao nos referenciarmos aos conceitos ensinados pela escola, redimensionados a um contexto inteligível para os alunos. O conceito científico escolar tem sua gênese orientada pela necessidade de transmitir o que é estabelecido como relevante para compor o currículo, portanto, originado fora da vida do aluno e transmitido de forma vertical, de cima para baixo, ou seja, dos documentos oficiais para a escola e da escola para o aluno.

A teoria da transposição didática de Chevallard (1991) e da recontextualização de Bernstein (1996), bem como perspectivas derivadas da transposição didática, como o modelo KVP (Knowledge, Values and Social Pratice) proposto por Clément (2004; 2006), são perspectivas dedicadas a esta adaptação, com grande contribuição para a transposição e recontextualização do conteúdo, no entanto, não incluem estudos aprofundados sobre como se dá, psicologicamente a apropriação dos conceitos científicos escolares pelos alunos, como o faz a Teoria Histórico-Cultural da Atividade, para com isso, entender as condições psicológicas dos alunos para a aprendizagem de conceitos.

Segundo Vigotski (2009), os conceitos científicos, além de serem formados fora do mundo cotidiano, são formados por meio de sistemas, por sistemas de conceitos co-subordinados que mantém relações com outros conceitos. Exigem maior esforço de atenção voluntária do pensamento abstrato e das funções psicológicas superiores quando comporado aos conceitos espontâneos.

De forma semelhante, os conceitos científicos escolares também trazem estas características dos conceitos científicos, além de serem apropriados pelos alunos em ambiente formal, não espontâneo -a sala de aula-, pois apesar desta fazer parte do cotidiano do aluno, trata-se de um ambiente sistematizado 
por regras particulares de participação e comportamento. Portanto, nesta pesquisa, ao trabalharmos com conceitos científicos escolares, consideramolos nestes aspectos de formação e estrutura sistêmica, semelhantes aos conceitos científicos.

Consideramos os conceitos espontâneos como aqueles originalmente formados pelo conhecimento cotidiano do aluno, desde a idade pré-escolar e que os conceitos científicos e espontâneos se distinguem, principalmente, em dois sentidos: da existência de uma ruptura epistemológica, e na origem psicológica de formação dos mesmos. Distinguem-se no sentido de ruptura epistemológica, pela qual Lopes (1999) explica que o conhecimento científico opera conceitos por meio de variáveis observadas isoladamente, em um mundo recomeçado, enquanto que o conhecimento cotidiano não sistematiza ou isola variáveis dos fenômenos complexos da realidade dada. No entanto, este sentido de ruptura epistemológica deve ser atribuído como um fato diante do qual o professor se vê desafiado a problematizar com seus alunos, não a reforçar de maneira a aliená-los do processo sócio-histórico-cultural da produção desse conhecimento.

Considera-se a distinção entre conceito espontâneo e conceito científico, no sentido da origem psicológica de formação dos mesmos, porque os conceitos espontâneos são conceitos de origem não conscientizada ${ }^{11}$ e os conceitos científicos pressupõem formação por tomada de consciência. Segundo Vigotski (2009), as crianças sabem operar espontaneamente e corretamente com os conceitos espontâneos, mas não tomam consciência deles, pois a atenção neles contida está sempre orientada para os objetos neles representados e não para o próprio ato de pensar que os abrange. Já os

(...) conceitos científicos - com sua relação inteiramente distinta com o objeto - mediados por outros conceitos - com seu sistema hierárquico interior de inter-relações-, são o campo em que a tomada de consciência dos conceitos, ou melhor, a sua generalização e a sua apreensão parecem surgir antes de qualquer coisa. (p. 290)

\footnotetext{
${ }^{11}$ A expressão de que os conceitos espontâneos são "não conscientizados" vem de Piaget e não se refere a um estado de inconsciência, como na terminologia de Freud, mas de uma consciência parcial. Nem inconsciente, nem totalmente consciente. Ver Vigotski (2009, p. 288).
} 
Segundo o mesmo autor e obra, o conceito científico só existe dentro de um sistema de conceitos co-subordinados, não relacionado diretamente com a realidade concreta, e por isso, pode permanecer abstrato. Pode ser alcançado pela generalização de um conceito espontâneo, o que é sinônimo de tomada de consciência do conceito espontâneo, e sinônimo de sistematização, se a generalização se manter por um sistema de relações de generalidade. Assim, o conceito científico promove a elevação do conceito espontâneo a conceito superior, contribuindo para sua sistematização e para o desenvolvimento dos conceitos espontâneos. O conceito espontâneo, por sua vez, proporciona concretude ao conceito científico.

Assim, essas contribuições reforçam os subsídios para a elaboração de uma aula em que a situação-problema parta da realidade objetiva, seja reduzida ao abstrato, e ao retornar ao concreto, este estará reorganizado, será o concreto complexificado e poderá fazer novas relações com outras generalizações dentro do sistema de relações de generalidade e prosseguir a complexificar-se. Nas palavras de Vigotski:

Se a tomada de consciência significa generalização, por sua vez, não significa nada senão a formação de um conceito superior, em cujo sistema de generalização foi incluído um determinado conceito como caso puro. Mas, se depois desse conceito surge um conceito superior, ele pressupõe necessariamente a existência não de um, mas de uma série de conceitos co-subordinados, com os quais esse conceito está em relações determinadas pelo sistema do conceito superior, sem o que esse conceito superior não seria superior em relação ao outro. Esse mesmo conceito superior pressupõe, simultaneamente, uma sistematização hierárquica até dos conceitos inferiores àquele conceito e a ele subordinados com os quais ele torna a vincular-se através de um sistema de relações internamente determinado. Desse modo, a generalização de um conceito leva à localização de dado conceito em um determinado sistema de relações de generalidade, que são os vínculos fundamentais mais importantes e mais naturais entre os conceitos. Assim, generalização significa ao mesmo tempo tomada de consciência e sistematização de conceitos. (VIGOTSKI, 2009, p. 292)

Tomamos este trecho como um exemplo de uma parte inicial do movimento do processo de formação de um conceito superior, em cuja natureza incluímos os conceitos científicos escolares, a partir de um conceito espontâneo, o que envolve a interação entre a realidade concreta e o sistema conceitual abstrato, entre a essência e a aparência, tanto da realidade concreta (totalidade), quanto dos conceitos científicos. 
No entanto, é preciso considerar que para o adolescente, os conceitos espontâneos pertencentes a sua realidade concreta já possuem um certo grau de sistematização, já que ao longo da vida escolar, os conceitos científicos contribuem para a sistematização dos espontâneos. Por isso, não podemos precisar sobre a natureza do conceito espontâneo do adolescente, bem como não podemos afirmar, por exemplo, que um conceito pertencente à realidade concreta do adolescente seja não conscientizado como o de uma criança que ainda não tomou consciência, no sentido descrito na citação acima, de um determinado conceito espontâneo.

Segundo a conclusão de Vigotski (2009), sobre o estudo experimental do desenvolvimento dos conceitos, os conceitos do adolescente e do adulto, cuja aplicação se restringe à experiência cotidiana, não ultrapassam o nível dos pseudoconceitos. Podem ser caracterizados apenas como noções gerais, isto é, como complexos. "Até mesmo o adulto está longe de pensar sempre por conceitos", (p. 228).

Sendo o pseudoconceito a forma aparente e funcional do conceito, e sendo o complexo uma forma menos sistematizada em relação ao pseudoconceito, os conceitos espontâneos do adolescente e do adulto podem percorrer por entre esses níveis de pensamento, já que os conceitos espontâneos também pertencem à experiência cotidiana, nesta operados de maneira correta, mas não sob a forma de conceitos superiores.

No entanto, entendendo ser possível que os conceitos espontâneos, e também os científicos escolares, possam ter algum grau de sistematização e que os adolescentes possam manipulá-los no plano das ideias, também podemos considerar que os conceitos espontâneos do adolescente são menos dependentes dos objetos materiais palpáveis do que no caso da criança, sendo possível que o ponto de partida das atividades com adolescentes não necessariamente sejam os objetos materiais, como na proposta metodológica de Galperin das Formações de Ações Mentais e Conceitos por Etapas, mas possam ser as representações orais e escritas. Não estamos, nem por um momento, tirando o mérito de atividades que se utilizam de objetos materiais, como os experimentos e os modelos. Apenas levantamos a possibilidade de 
discussão no plano das ideias com o adolescente, para justificar nosso modo de condução mediado pela linguagem oral, escrita, simbólica e por meio de vídeos assistidos pelos alunos.

O importante a ser destacado na diferenciação entre conceitos espontâneos e conceitos científicos para a análise das interações discursivas e a observação de indícios de formação de conceitos é a interação entre os mesmos, na qual os conceitos espontâneos proporcionam concretude aos conceitos científicos e estes proporcionam sistematização aos conceitos espontâneos em um longo e dialético processo que faz parte da formação dos conceitos, e é mantido pelas relações de generalidade entre estes dois tipos de conceitos e entre conceitos científicos pertencentes ao sistema conceitual.

Do mesmo modo, é preciso considerar a respectiva aproximação entre a realidade concreta do cotidiano do aluno como contexto de origem dos seus conceitos espontâneos e o sistema conceitual, inicialmente abstrato para o aluno, dos conceitos científicos escolares como contexto de origem do conceito científico, para que se ampliem as relações de generalidade entre conceitos.

Entendidas as relações entre conceito espontâneo, conceito científico e sistema de relações de generalidade, pode-se depreender que a formação do conceito superior a partir do conceito espontâneo se dá por um processo de tomada de consciência e complexificação das relações de generalidade no sistema conceitual. Assim, observar a formação de um conceito científico no aluno implica, dentre outros fatores, em observar esta complexificação de relações de generalidade entre os conceitos, ou seja, observar a dinâmica das relações entre conceitos ao longo do tempo.

$\mathrm{Na}$ aula preparada nesta pesquisa, o sistema conceitual que abrange 0 conceito de entalpia e suas respectivas relações de generalidade foi pensado desde as relações com conceitos imediatamente relacionados, como entalpia de formação, reação de combustão, balanceamento da reação, cálculo de entalpia, combustível, comburente, calor, energia, até as relações com conceitos indiretamente relacionados ao conceito de entalpia dentro do sistema de relações de generalidade, como o preço do combustível, sistema produtivo dos combustíveis, sistema produtivo de alimentos, implicações ambientais, 
implicações sociais, implicações políticas, dentre outros, compondo, como já mencionado, os limites da totalidade pensada para a atividade de aprendizagem da aula.

Entendemos todos estes conceitos como conceitos científicos se considerados em seu processo de produção sócio-histórico-cultural de origem na comunidade científica. Por outro lado, dependendo do nível de consciência e apropriação sócio-histórico-cultural desses conceitos pelos alunos adolescentes, podem se encontrar em estágios de complexos ou pseudoconceitos, ou existirem sob a forma de conceitos espontâneos a serem sistematizados, ou podem até possuir a sistematização de um conceito científico escolar, o que, por sua vez, dependerá das experiências do aluno e irá refletir no processo de apropriação, de modo a poder revelar momentos iniciais da formação de alguns conceitos e momentos mais adiantados em relação a outros.

\subsubsection{Realidade Concreta}

Tomamos por realidade concreta o contexto que deve envolver os conceitos a serem apropriados, o mundo historicamente construído pela humanidade posto diante do sujeito e com o qual interage de diversas maneiras. De caráter cotidiano, real, perceptível, fenomenológico, empírico e não necessariamente conscientizado, considerada aqui como sinônimo de contexto histórico-social, contexto social, realidade objetiva, realidade objetal.

Assim como o conceito de meio ambiente ecológico organizado por Bronfenbrenner (1996), o qual inclui o micro, meso, exo e microssistema social que cercam o sujeito, destacamos as vivências sociais do aluno, desde aquelas nas quais tem contato pessoal direto e aquelas que tem contato indireto, como as apresentadas pelos meios de comunicação, até aquelas com as quais não tem contato, entretanto $o$ atingem sem que tenha consciência do fato ou da causa.

Leontiev (2012), ao discorrer sobre o caráter transitório da adolescência e o surgimento de novos interesses do perfil de aluno da escola secundária, destaca o surgimento da necessidade "de conhecer não apenas a realidade 
que o cerca, mas de saber também o que é conhecido acerca dessa realidade" (p. 63). Daí a necessidade que se mostra para a educação básica do Ensino Médio em considerar a realidade concreta no processo de ensino e aprendizagem do adolescente.

Como as relações de generalidade acabam por relacionar conceitos presentes em contextos mais próximos e mais distantes dos conceitos da termoquímica, podemos identificar como se dão as relações CTSA presentes na aula, por meio do delineamento das relações estabelecidas dentro do sistema de relações de generalidade do conceito, criado a partir da sequência de atividades pelas quais o aluno percorre durante a aula.

Nesta pesquisa, observamos as interações discursivas e textos dos alunos. Ao analisar as interações discursivas, tem-se palavras utilizadas pelos alunos e pelos professores, dentre elas, conceitos espontâneos e conceitos científicos escolares, pronunciadas dentro de contextos da aula e contextos de vida, e cercadas de relações, das quais só podem ser observadas as relações externalizadas, sendo estas produzidas coletivamente.

\subsubsection{Realidade objetal e atividade do sujeito}

Esta relação tem origem nos estudos sobre a atividade interna e externa ao sujeito. Segundo Leontiev (1983, p. 80-81), a distinção fundamental na qual se baseava a psicologia clássica, entre atividade corpórea externa, realizada no mundo exterior e atividade interna, realizada nos processos da consciência, deve ser substituída por outra distinção: a distinção entre a realidade objetal, com suas formas transformadas, e a atividade do sujeito, que implica em si mesma tanto os processos internos como os externos, já que a consciência é formada a partir dos processos externos, sendo uma realização social. Disso implica que a separação da atividade em duas esferas completamente distintas não procede. Daí deriva a tese da unidade entre a atividade interna e externa no sujeito.

A partir desta tese, consideramos que a preparação da atividade de ensino que busca superar a ruptura entre os conceitos químicos abordados em aula e o contexto histórico-social do aluno, deve proporcionar generalizações 
para além do sistema de relações de generalidade dos conceitos químicos, vinculando este sistema à realidade objetal do aluno, a qual, neste trabalho, está associada ao conhecimento sobre seu contexto histórico-cultural. Logo, não se trata de objetos palpáveis, modelos ou experimentos, mas questões de seu tempo, fatos históricos reais que envolvem aspectos econômicos, políticos, científicos, tecnológicos e ambientais, buscando proporcionar as relações CTSA.

\subsubsection{Apropriação e assimilação}

Dentro da fundamentação teórica adotada, o conceito de apropriação é compreendido como sendo o processo por meio do qual o sujeito individual "reproduz em si mesmo as formas histórico-sociais da atividade" (DAVIDOV, 1988, p. 4).

Davídov (1988) destaca o caráter social do processo de apropriação, seu vínculo com a formação educacional e com o desenvolvimento mental do homem:

A característica essencial da apropriação das capacidades é que a criança a realiza somente na vida conjunta com os adultos, na comunicação com eles e sob sua direção e, também, na atividade conjunta com outras crianças. (p. 62)

$O$ exame do enfoque de Vigotski e Leontiev sobre o problema do desenvolvimento mental permite que cheguemos às seguintes conclusões. Primeiro, no sentido mais amplo, a educação e o ensino de uma pessoa não é nada mais que sua "apropriação", a "reprodução" por ela das capacidades desenvolvidas histórica e socialmente. Segundo, a educação e o ensino ("apropriação") são as formas universais de desenvolvimento mental do homem. Terceiro, a "apropriação" e o desenvolvimento não podem ser dois processos independentes, pois se correlacionam como a forma e o conteúdo de um único processo do desenvolvimento mental humano. (p. 62)

Em Nuñes (2009); Davídov e Márcova (1987); Davydov (1999) apud Libâneo e Freitas (2013), apropriação e assimilação são apresentados como sinônimos. De acordo com Davídov e Márcova (1987),

Assimilação é o processo de reprodução, pelo indivíduo, dos procedimentos historicamente formados de transformação dos objetos da realidade circundante, dos tipos de relação entre eles e o processo de conversão desses padrões, socialmente elaborados, em formas de subjetividade individual [...] a assimilação nem sempre conduz ao desenvolvimento. Em alguns casos, a assimilação pode conduzir a criança ao domínio de conhecimentos, habilidades e hábitos; em outros casos, ao domínio das capacidades, das formas 
gerais da atividade psíquica. Neste último caso, se pode falar em avanços essenciais no desenvolvimento psíquico. (tradução nossa, p. 321 e 322)

Nuñes (2009), ao apresentar um estudo sobre a teoria de Galperin coloca que "Assimilar significa apropriar-se do objeto do conhecimento" (p. 94) e que "o processo de assimilação do conceito é também o processo de sua aplicação em forma de atividade" (p. 96), pois o ponto final da aquisição de conhecimentos não é a assimilação de conceitos abstratos, mas também a assimilação das formas de aplicação dos conceitos na atividade.

Este autor destaca, a partir da teoria de Galperin, que a particularidade mais importante do processo de assimilação é o seu caráter ativo, no qual as propriedades intrínsecas e extrínsecas do objeto são refletidas nas imagens sensoriais e conceituais por meio de diversas formas de atividade, mediada pela comunicação, e não por meio da contemplação.

Entendemos que a apropriação e a assimilação não incidem apenas sobre o conceito, mas perpassam todos os elementos da atividade humana, desde o motivo até a objetivação, bem como as formas de como as atividades se inter-relacionam. $\mathrm{Na}$ atividade de estudo, o aluno não consegue assimilar se não se apropriar do motivo, da situação-problema ou tarefa, das necessidades, das ações e condições necessárias para objetivá-la, da maneira como se dá sua avaliação, de modo que a atividade de aprendizagem não tenha seu fim na apropriação dos conceitos, um fim em si mesma, promovendo um desenvolvimento multilateral (DAVÍDOV e MÁRCOVA, 1987) de capacidades internas e externas, bem como o desenvolvimento psíquico e operacional do sujeito.

\subsubsection{Significação}

Consideramos, aqui, as contribuições de Leontiev ao relacionar a formação de conceitos ao processo de significação.

De acordo com Leontiev (1983), a significação consiste na forma ideal, reduzida ao contexto idiomático de existência das características, nexos e relações do mundo objetal, produzidos e apropriados historicamente pela prática social conjunta, sendo a significação o reflexo dos objetos da realidade 
concreta na língua e na consciência, unida à objetivação das necessidades humanas.

Segundo o autor, historicamente, esta união se rompe por causa das contradições da produção mercantil, a qual gerou a contraposição entre o trabalho concreto e o abstrato, e a alienação da atividade humana.

Ao nosso ver, este rompimento pode ser projetado para a atividade de ensino-aprendizagem escolar, na qual ainda predomina a inexistência da união entre o reflexo dos objetos na língua e consciência e a atividade voltada ao atendimento de uma necessidade humana, quando o ensino impõe ao aluno um significado pronto do objeto de estudo (conceito), sem que o aluno conheça as atividades humanas nas quais esse objeto é necessário, e, de preferência, possa vir a atender suas necessidades.

Segundo Leontiev (1983, p. 116), a formação de conceitos é o resultado do processo de apreensão de significações historicamente elaboradas; processo que transcorre dentro da atividade do aluno, em condições de comunicação com as pessoas que o rodeiam. Por trás das significações idiomáticas se escondem as formas de ação (operações) socialmente elaboradas, em cujo processo as pessoas transformam e conhecem a realidade objetiva.

De acordo com Leontiev (1983, p. 225), "a significação é a forma em que um determinado homem chega a dominar a experiência da humanidade, refletida e generalizada" (tradução nossa). A significação é diferente do sentido, que é pessoal. "Reflete a experiência humana cristalizada. O conjunto das representações de uma sociedade dada." (idem, p. 225)

Considerando a produção do conhecimento como parte da experiência da humanidade, e a produção de conceitos como parte da produção de conhecimento, aquilo que o sujeito pensa ou compreende sobre determinado conceito pode não coincidir exatamente com o significado do conceito, sendo representado pelo sentido pessoal. Para que o aluno apreenda a significação do conceito, é preciso haver uma atividade que aproxime significação e sentido pessoal por meio da necessidade de significação do conceito. 
No caso deste trabalho, contamos com a contribuição da forma de trabalho desenvolvida pelo grupo de professores e alunos do projeto de Educação Popular, no qual o aluno, desde o início de sua participação no grupo, é estimulado a falar e é livre para expressar opiniões pessoais em relação aos assuntos discutidos em aula. No início do ano letivo, os alunos se mostram geralmente tímidos e se expressam pouco, mas, ao longo do tempo, passam a se sentir mais à vontade, graças à persistente e incentivadora mediação dos professores a favor das manifestações dos alunos. Quando nossa aula foi aplicada, mês de agosto, a turma já havia internalizado esta prática de sala de aula, de modo que os alunos se sentiam à vontade em se expressar. A aproximação entre sentido pessoal e significado dos conceitos envolvidos perpassa toda a aula aplicada, na medida em que o caráter real dos problemas evoca o sentido pessoal das opiniões dos alunos, e, ao nosso ver, acompanha a interação entre conceitos espontâneos e científicos. 


\section{Metodologia}

Retomando o problema da desconexão entre os conteúdos ensinados na escola e a realidade concreta do aluno, mais precisamente, entre os conceitos da termoquímica pertencentes a um sistema de conceitos científicos escolares, e problemas reais de caráter socioambiental, ambos construídos sócio-histórico-culturalmente, sentimos a necessidade de analisar como ocorre o processo de formação do conceito químico escolar em conjunto com seus aspectos socioambientais, nas interações discursivas promovidas durante uma aula de química. E para a preparação e análise desta aula, este trabalho intencionou utilizar questões sociocientíficas (QSC) como instrumentos de ensino-aprendizagem da Teoria Histórico-Cultural.

Para apresentar as ações que lavaram à objetivação destes propósitos, pretendemos, primeiramente, localizar a pesquisa dentro da abordagem metodológica qualitativa e de seu contexto de aplicação prática, e posteriormente, descrever as ações realizadas para a busca de respostas ao nosso problema de pesquisa, a saber, o percurso metodológico da elaboração da sequência de atividades, os procedimentos da coleta de dados (interações discursivas e textos), e o procedimento de análise dos dados.

\subsection{Abordagem Metodológica}

O trabalho aqui apresentado pretende adotar a abordagem dos estudos histórico-culturais. Nessa perspectiva teórica e metodológica, os sujeitos da pesquisa são vistos como parte de um processo histórico. Esses sujeitos advêm das interações estabelecidas entre os indivíduos e o contexto social em que estão inseridos. Esse referencial rompe com o ideário positivista e encara a construção dialética dos sujeitos com o ambiente historicamente construído (VIANNA, 2010). 
O estudo realizado aproxima-se da linha de pesquisa em ensino e aprendizagem, possui como foco e objetivo investigar alguns aspectos relacionados à verificação de indícios da formação de conceitos em episódios de interação discursiva de sala de aula, em textos produzidos pelos alunos, bem como analisar a metodologia envolvida no processo de formação de conceitos.

\subsection{Contexto de aplicação da pesquisa}

A aplicação da pesquisa foi realizada em um projeto social de Educação Popular, que se configura em um cursinho pré-vestibular, em um grupo de estudos para os professores e em uma revista eletrônica, denominado grupo CIMEAC (Centro de Investigações de Metodologias Alternativas Conexão), de Ribeirão Preto. Apesar de somar, até o momento, mais de 15 anos de existência, não possui sede própria e já foi alocado em diversos pontos da cidade. No período da pesquisa, tinha como sala de aula um depósito de utensílios de jardinagem do clube de funcionários da USP, o qual já possuía um quadro negro e assim foi adaptado como sala de aula.

De acordo com Kato (2011), o projeto Conexão visa a contextualização de temas de interesse público com a realidade dos trabalhadores estudantes do projeto, bem como a interdisciplinaridade, por meio de planejamento e reestruturação curricular. Possui metodologia educacional alternativa à tradicional, que converge para a criação de novas perspectivas nos alunos e requer um processo de criação vinculado às realidades vivenciadas.

Para descrever as principais características dos grupos sociais formadores do público deste e de outros cursinhos populares de Ribeirão Preto e região, bem como do cenário social no qual se encontram, utiliza-se das categorias capital social, capital cultural, capital econômico e habitus, do sociólogo Pierre Bourdieu (1930-2002).

O acesso a Universidade pública e suas relações com o ensino básico privado e público devem passar por uma discussão política e ideológica. A manutenção da estrutura social, que para Bordieu (1979) implica na conjuntura econômica, social e politica, exigem que as frações de classe hegemônicas não estejam no mesmo espaço 
educacional que a fração de classe dominada distinguindo o público das escolas públicas e privadas, evidenciando tais mecanismos ideológicos de distinção das frações de classes. Esse isolamento implica em uma diferenciação não só do capital cultural, mas também no capital social de cada grupo, os quais são responsáveis pelo distanciamento entre classes sociais, não só pelo estado objetivado das intenções e estratégias no jogo social, mas também pela composição do habitus que dirige as formas de disposições das atitudes e modos de vida do sujeito na sociedade. (KATO, 2011, p. 7)

Diante deste cenário, os cursinhos populares surgem por meio de mobilizações voluntárias, concentrando forças no capital social para que seja possível gerir um movimento que busca proporcionar espaços de acesso ao capital cultural mencionado. Assim, o projeto de Educação Popular CIMEAC se configura como um destes espaços, guardando a característica da ausência de capital econômico.

Esta condição requer esforços de mobilização do capital social por meio de conscientização do público e criação de eventos sociais como encontros entre os cursinhos, visitas em espaços culturais gratuitos ou de baixo custo, arrecadação de recursos financeiros por meio de rifas, elaboração e venda pratos como pizzas, bolos, dentre outros, além da participação dos alunos nos processos decisórios de gestão e divulgação ${ }^{12}$ do grupo, os quais tem poder de opinião e voto, na busca do desenvolvimento de um ambiente horizontal de convivência. Assim os esforços relacionados ao capital social promovem o funcionamento, participação e a identidade dos participantes com o grupo.

O cursinho pré-vestibular Conexão do projeto CIMEAC funciona no período noturno, com aulas de segunda à sexta feira. $O$ currículo é dividido nos módulos temáticos Água, Guerra, Economia, Trabalho, Energia, Modernidade e Direitos Humanos, distribuídos, nesta sequência, ao longo do ano, sendo que cada módulo tem a duração média de um mês. As aulas não são separadas por disciplinas, são aulas multidisciplinares nas quais participam de 2 a 3 professores de diferentes áreas. No caso, os episódios analisados estão inseridos em uma aula de ciências naturais contida no módulo "Energia", com

\footnotetext{
${ }^{12}$ A divulgação geralmente é feita em grupos de alunos e professores que visitam escolas públicas para informar sobre o processo seletivo, ou panfletagem nas ruas. No entanto, em 2016, houve a mobilização dos alunos na produção de um documentário de mais de 40 minutos sobre o cursinho popular Conexão, intitulado "Arena Conexão: do outro lado da lousa", disponível no youtube em https://www.youtube.com/watch?v=6pi4mjEFS-g
} 
foco na química, e participação, além da professora pesquisadora, de um professor de química e um professor de biologia. O dia de aula, ou dia-aula, compreende o período das $19 \mathrm{~h}$ às $22 \mathrm{~h}$, com intervalo de 15 a 20 minutos. No entanto, uma aula pode ter a duração de dois dias-aula, com foi o caso analisado neste trabalho, e é preparada em conjunto pelos professores envolvidos, sendo que, os alunos também participam da preparação das aulas sempre que surgem interesses e demandas por parte dos mesmos. No caso da aula analisada nesta pesquisa, foi preparada e validada pela doutoranda junto ao grupo de pesquisa Ciência, Comportamento e Ambiente (CCA), coordenado pelo prof. Dr. Mauricio dos Santos Matos, orientador desta pesquisa, e junto aos professores do grupo CIMEAC.

O ambiente de aula pode ser caracterizado por alguns fatores que se aproximam da perspectiva de educação humanística que buscamos, como a disposição das carteiras ora em círculo, ora em grupos, nunca em fileiras, a abordagem temática por meio de temas relacionados à realidade concreta do aluno; a proposição de situações-problema a serem resolvidas coletivamente; de atividades investigativas; de situações em que os alunos representam papéis, defendem posições, tomam decisões; momentos compartilhados de elaboração de autoavaliação por parte dos professores e dos alunos, dentre outros, o que caracteriza também um ambiente em que a aula proposta por esta pesquisa não estaria fora do cotidiano metodológico do grupo.

O grupo de professores faz um trabalho voluntário que se divide principalmente nas seguintes funções: preparação de aulas, relatos de aulas, preparação do material didático, estudos de textos científicos para embasar temas e discussões dos módulos, assuntos burocráticos, reuniões pedagógicas e organização da revista eletrônica Cadernos CIMEAC, dentre outros. A realização dessas funções fica distribuída temporalmente entre reuniões que acontecem aos sábados e durante a semana, em grupos mediados pelo aplicativo WhatsApp ${ }^{13}$.

\footnotetext{
${ }^{13}$ Aplicativo multiplataforma de mensagens instantâneas e chamadas de voz para smartphones que permite a comunicação individual ou em grupos por meio do envio de mensagens de texto, áudios, imagens, vídeos e documentos, além de permitir ligações telefônicas grátis por meio de uma conexão com a internet.
} 
Normalmente, a preparação das aulas é iniciada no sábado pelo grupo como um todo, contemplando o conjunto de aulas da semana, a fim de se buscar inter-relações entre as aulas das diferentes áreas, divididas em Ciências Naturais, Ciências Humanas, Matemática e Linguagem. Após a reunião presencial, os professores que ministram os mesmos dia-aula refinam a preparação para sua aula específica. No caso da aula preparada para a coleta de dados desta pesquisa, o processo de preparação foi iniciado no Grupo de Pesquisa Ciências, Comportamento e Ambiente (CCA), respeitando o calendário CIMEAC e o módulo Energia, com a escolha do tema da aula correspondente ao módulo, o qual, na ocasião, teve como mote o conceito de metabolismo social, apresentado na discussão de Oliveira e Fraga (2011), de acordo com a qual o termo é designado como

(...) uma propriedade coletiva de uma sociedade ou grupo com relação às entradas de energia e materiais ao seu sistema, provendo sobrevivência e permitindo [...] usos dos recursos de energia e matéria disponíveis. Em última análise, o estudo do metabolismo social é uma ferramenta para se compreender os processos de (in)sustentabilidade(s) de uma sociedade em uma determinada época. Constitui, portanto, uma forma de apreender a lógica dos métodos de produção e relacionamentos sociais a partir dos fluxos de energia e materiais retirados, transformados e devolvidos à natureza. (p. 1).

A partir deste texto, lido e discutido pelos professores, foi intencionado que todas as aulas do módulo buscassem estabelecer relações com este conceito e, assim, se seguiu para a aula preparada por esta pesquisa, cuja preparação será detalhada no item 4.3.

Os relatos das aulas são compartilhados entre todos os professores por meio do aplicativo WhatsApp, que se configura como um espaço de aprendizagem entre professores com mais ou menos experiência nesse trabalho, avaliação das aulas, reflexão sobre a prática planejada, dentre outros afazeres.

Destacamos, ainda, a dimensão atrelada à pesquisa e divulgação científica realizada por meio do periódico Cadernos CIMEAC, mantido como veículo acadêmico de diálogo e reunindo pesquisadores das mais diversas áreas e instituições com publicações de trabalhos interessados em refletir sobre as condições práticas e teóricas da Educação Popular em suas diversas 
vertentes, como: pedagogia, políticas públicas, currículo, história da educação, filosofia da educação, ensino de ciências, dentre outras.

O público de alunos é formado por adolescentes que cursam o Ensino Médio ou já o concluíram. Dentre os que já concluíram, a maioria, egressa do ensino público e maior de idade, trabalha para ajudar na renda da família, no comércio, como lojas, restaurantes, bilheterias de cinema, e em empregos temporários como auxiliares em oficinas e na construção civil. Em sua maioria, os sujeitos da pesquisa são alunos com o perfil de alunos do Ensino Médio da rede pública. Apenas 2 dos 21 alunos participantes eram egressos de escolas particulares.

Para obter uma vaga no projeto, o aluno passa por um processo seletivo com caráter de sondagem de perfil, constituído por 3 etapas: inscrição com entrega de documentos socioeconômicos, prova composta por 5 questões de matemática e 5 questões da área de códigos e linguagens, e entrevista com os professores. O candidato deve comprovar a renda familiar por meio de documentos seus e dos responsáveis, como holerite, carteira de trabalho, comprovante de endereço, dentre outros, a fim de justificar que não possui condições financeiras para frequentar um cursinho pré-vestibular particular, privilegiando-se, dessa forma, o acesso do público carente ao projeto, sendo necessário o número de 30 candidatos para que as turmas sejam formadas e as aulas se iniciem.

No processo seletivo de 2015 os candidatos podiam realizar suas inscrições pela internet ou presencialmente. Apresentaremos alguns dados retirados da ficha de inscrição dos 15 candidatos que realizaram a inscrição presencialmente ${ }^{14}$. A tabela 1 traz a informação sobre a idade desses candidatos, a tabela 2 sobre o nível de escolaridade, e a figura 1 sobre a renda mensal total da residência.

\footnotetext{
${ }^{14}$ Os dados das inscrições online não estavam disponíveis para consulta.
} 
Tabela 1 - Idade dos candidatos de 2015, de acordo com as inscrições presenciais.

\begin{tabular}{cc}
\hline Idade & $\begin{array}{c}\text { Número de } \\
\text { candidatos }\end{array}$ \\
\hline 17 & 3 \\
18 & 1 \\
19 & 4 \\
20 & 3 \\
21 & 1 \\
23 & 2 \\
25 & 1 \\
\hline
\end{tabular}

Fonte: Schneider-Felicio (2018).

Tabela 2 - Nível de escolaridade dos candidatos de 2015, de acordo com as inscrições presenciais.

\begin{tabular}{lc}
\hline Nível de escolaridade & $\begin{array}{c}\text { Número de } \\
\text { candidatos }\end{array}$ \\
\hline Fundamental imcompleto & 0 \\
Fundamental completo & 0 \\
Médio incompleto & 4 \\
Médio completo & 9 \\
Técnico incompleto & 2 \\
Técnico completo & 1 \\
Superior incompleto & 1 \\
Superior completo & 0 \\
\hline
\end{tabular}

Fonte: Schneider-Felicio (2018).

No caso do nível de escolaridade, o número de alunos totaliza 17 pois dois candidatos assinalaram dois níveis: um candidato, os níveis médio e técnico incompleto, e outro os níveis médio completo e técnico incompleto. 
Figura 1: Renda mensal total da residência, de 12 candidatos de 2015, de acordo com as inscrições presenciais.

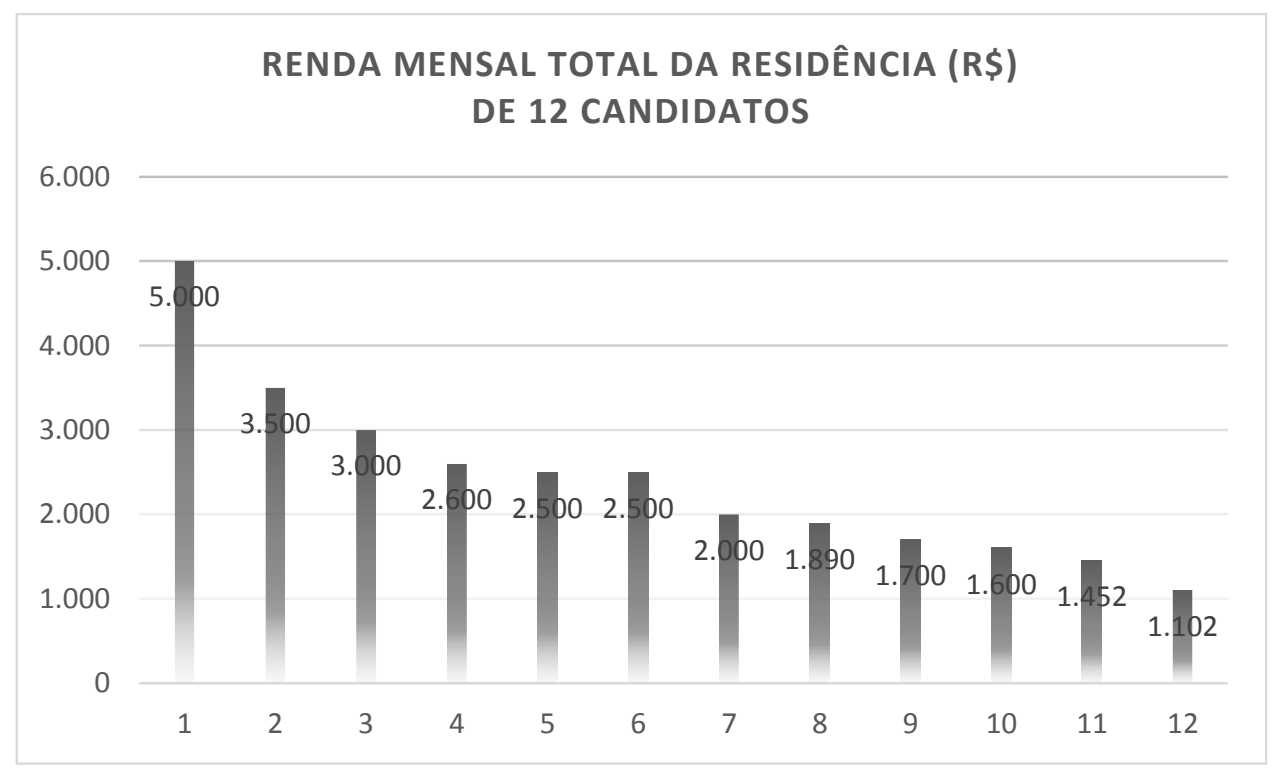

Fonte: Schneider-Felicio (2018).

No caso da renda mensal total da residência, informada no momento da inscrição com a comprovação de documentos, apenas 12 dos 15 candidatos forneceram a informação, sendo que cada coluna do gráfico representa um candidato.

\subsection{Procedimentos de coleta de dados}

A partir da necessidade de se analisar o processo de formação de conceitos escolares conectados à realidade concreta, com o foco principal nos conceitos da termoquímica em meio a tomada de consciência de problemas socioambientais, realizamos uma revisão bibliográfica a respeito de como estes conceitos estão sendo considerados pelas pesquisas em ensino-aprendizagem da química, verificando que poucas pesquisas se ocupam na preparação de atividades que unam os conceitos químicos à realidade histórico-social do aluno e que algumas metodologias ativas tem o fim em si mesmas, mantendo o desenvolvimento do conhecimento químico escolar alheio a essa realidade. 
Além da pesquisa bibliográfica, buscamos elaborar e aplicar uma sequência de atividades que promovesse o estudo destes conceitos químicos em união com a realidade histórico-social do aluno, e que considerasse as interações discursivas o seu principal meio, assim como o considera a Teoria Histórico-Cultural. Dessa forma, as interações discursivas de sala de aula tornou-se a nossa principal fonte de dados para a análise de como se dá a formação dos conceitos da química no momento da concretização da atividade propostas em aula.

Assim, a coleta de dados realizada neste trabalho contou com a filmagem da aplicação de uma sequência de atividades (SAt) incorporada ao material confeccionado pelo projeto CIMEAC, que pode ser consultada no apêndice A. A filmagem foi realizada por meio de três câmeras digitais que captaram som e imagem da sala como um todo e, nos momentos de discussão em grupos, cada câmera foi direcionada para o respectivo grupo, captando, assim, o registro das interações discursivas entre professor e aluno e entre os próprios alunos. Um gravador de som portátil digital acompanhou a professora nos momentos de atendimento às solicitações dos alunos nos grupos. Assim, foi necessário, para certos momentos de transcrição, um cruzamento de informações entre câmeras e áudio. A coleta de dados também contou com um pequeno texto produzido pelos alunos ao final da aplicação da Sat, o qual solicitava, após o término da aula, uma posição do aluno perante a justificativa de escolha de um carro em função do combustível e da discussão ocorrida.

A aplicação da sequência de atividades (SAt) foi realizada em agosto de 2015, em uma turma de curso pré-vestibular do projeto de Educação Popular CIMEAC, no qual a pesquisadora trabalha como colaboradora junto a nove professores em trabalho voluntário, desde 2013, localizado, porém não vinculado, às dependências da Universidade de São Paulo, em Ribeirão Preto. A pesquisadora foi a professora que elaborou e aplicou a sequência didática, na qual participaram 21 alunos, 3 professores auxiliares -2 no primeiro dia, sendo um licenciando em química e um licenciando em biologia, e 1 no segundo dia, biólogo e mestre em ensino de ciências - e teve a duração de, aproximadamente, cinco horas, distribuídas em duas horas e trinta minutos por dia, no período noturno, o que equivaleria a seis aulas de 50 minutos do 
sistema escolar brasileiro. Os principais dados considerados para a análise são as interações discursivas. Os textos e anotações em caderno de campo foram assumidos como dados complementares de apoio.

\subsection{Percurso metodológico de elaboração e validação da sequência de atividades de ensino}

Primeiramente, informamos que todos os dados disponibilizados neste trabalho referem-se à segunda aplicação de uma sequência de atividades de ensino (SAt) proposta, já que, anteriormente a esta, no mês de junho de 2015, uma SAt piloto foi aplicada aos alunos, sob o mesmo tema, na qual a pesquisadora assumiu o papel de observadora enquanto outro professor do projeto ficou responsável pela aplicação da SAt. Todavia, julgamos que a condução expositiva, nesta primeira aplicação, mostrou-se demasiadamente prolongada, com pouca participação dos alunos, além de não serem atingidas todas as discussões pretendidas na aula por erro nas estimativas de tempo, fazendo com que a aula ficasse restrita apenas à explicação e exemplificação, pelo professor, dos conceitos de calor, entalpia, entalpia de transições físicas, entalpia de transformações químicas, entalpia padrão de formação, reação endotérmica e exotérmica, entalpia de combustão, combustíveis e cálculo de variação de entalpia de combustíveis. A segunda parte dessa aula, referente à primeira aplicação da SAt, pretendia discutir a produção e 0 uso de combustíveis pelo homem e os impactos sociais e ambientais envolvidos, mas o tempo não foi suficiente para sequer iniciarmos esta discussão.

Avaliamos que a forma como a primeira SAt foi preparada não possuía uma situação-problema em conformidade com a fundamentação teórica adotada. Ao invés disso, a colocava em segundo plano e, ao final da aula, como uma aplicação e discussão dos conceitos químicos. A estrutura da primeira SAt acabou resultando em uma aula dividida em duas partes: a introdução teórica expositiva dos conceitos químicos, separada dos problemas de aplicação destes conceitos em meio a discussões socioambientais (QSC). Esta separação manteve justamente o caráter que pretendíamos superar, 
concernente à ruptura entre os conceitos científicos escolares e suas relações com a realidade social do aluno, como já discutido por Engeström (2002).

Seria preciso considerar a unidade entre atividade externa e atividade interna do sujeito (Leontiev, 1983) como uma constante no decorrer da aula, colocando, em destaque, o uso de situações-problema que, conforme proposto por Vigotski (2009), necessitam de conceitos científicos - no caso deste trabalho, de conceitos químicos - para sua objetivação. Também deveriam ser consideradas questões sociocientíficas (QSC) e relações CTSA, a fim de contribuir para a tomada de consciência dos problemas socioambientais relacionados aos conceitos químicos, para que estes fossem pensados em unidade com os problemas socioambientais reais dos quais gostaríamos que tomassem consciência. Tudo isso em meio a um processo coletivo no qual os alunos interagem com os parceiros de atividade: seus pares e os professores.

Segundo Leontiev (2012), a atividade é a relação coincidente entre necessidade, motivo e objeto, ou seja, a necessidade deve coincidir com o objeto da atividade, gerando o motivo da ação. Assim, a atividade não pode ser considerada apenas ação, devendo ser intencional e consciente.

O presente trabalho propõe um conjunto de atividades de aprendizagem que contenham problemas reais, os quais geram a necessidade do estudo de conceitos químicos e de conceitos socioambientais que os abranjam para a sua resolução, gerando, por sua vez, o motivo para o aluno realizar as ações para o estudo desses conceitos, almejando a reprodução das formas históricosociais ${ }^{15}$ da atividade, ou seja, sua apropriação.

É nesse processo de apropriação que se dá o início da formação de novos conceitos e a continuação da formação de conceitos com os quais os alunos já tiveram contato, e a transformação da percepção sobre a realidade concreta devido à qualidade real, sócio-histórico-cultural, dos problemas colocados. A qualidade real deve incluir o aluno como sujeito da atividade, de modo a manter o seu motivo. Acreditamos que a vinculação do problema real

\footnotetext{
${ }^{15}$ Nesse estudo, não trabalhamos com a necessidade histórica que originou o conceito químico, mas sim com a necessidade do conceito dentro de um contexto contemporânea ao aluno, que não deixa de possuir um caráter histórico-social e real.
} 
ao aluno é fundamental para a necessidade gerar o motivo da ação em busca do conceito químico. Além do caráter real, o caráter controverso das QSC também contribui, no nosso caso, indiretamente, para gerar o motivo das ações de estudo dos conceitos da química, e, principalmente, para a tomada de consciência sobre problemas socioambientais da realidade concreta do aluno.

Esta é a síntese de nossa proposta inicial para a interação entre a Teoria Histórico-Cultural da Atividade e as propostas CTSA, com a abordagem das QSC, na qual as QSC figuram-se como instrumentos que perpassam a discussão temática dos problemas propostos, contribuindo, por meio de controvérsias reais, com o motivo da ação que objetiva a apropriação de conceitos científicos em unidade com problemas reais, isto é, funcionando como instrumentos motivadores da atividade de ensino-aprendizagem ${ }^{16}$.

A QSC que perpassa a atividade de crítica ambiental por meio da análise do sistema produtivo dos biocombustíveis é a questão da degradação socioambiental causada pelo uso de sementes transgênicas unidas a agrotóxicos na produção dos biocombustíveis. Os aspectos sociocientíficos, que podem ser considerados como QSC mais pontuais, abordados na aula, são os aspectos econômicos que relacionam a energia liberada pelo combustível ao seu preço, e a poluição relacionada à emissão de $\mathrm{CO}_{2(\mathrm{~g})}$ pelo uso de combustíveis.

Pretendemos esclarecer as intenções, explicitadas acima, ao longo da descrição do processo de elaboração da Sequência de atividades. A descrição metodológica que segue foi elaborada pensando-se nos momentos de preparação da segunda SAt, nos quais os objetivos ainda eram intenções não concretizadas. Isso implica ao leitor considerar a possibilidade de que nem todas as intenções, descritas a seguir, conseguiram ser concretizadas na prática.

Diferentemente da primeira, a segunda SAt foi pensada, priorizando-se a interação dos alunos com seus pares, em grupos, a mediação da professora na

\footnotetext{
${ }^{16}$ Aqui nos referimos à atividade de aprendizagem (DAVÍDOV e MÁRCOVA, 1987; RUBTSOV, 1996) reconhecendo que ela está imbricada à atividade de ensino do professor. Dessa forma as QSC são por nós consideradas um instrumento de ensino-aprendizagem.
} 
resolução de situações-problema nesses grupos e em discussões com a sala como um todo, desde o início da aula.

Ao longo dos estudos e como forma de adequar a linguagem à Teoria Histórico-Cultural da Atividade, decidimos denominar a nossa organização de aula por meio do uso da expressão "Sequência de Atividades (SAt)", propondo o reconhecimento da presença dos elementos da atividade que, segundo Leontiev (1983), compreende a necessidade, objeto, motivo, ações e operações, bem como a interação entre os mesmos. No transcorrer da descrição da preparação da SAt, apresentaremos mais detalhadamente nossas aproximações com esses elementos.

A elaboração da SAt intencionou, em primeiro lugar, a abordagem de um tema que tornasse possível aos alunos perceberem as inter-relações entre o conteúdo químico e os aspectos socioambientais reais a serem abordados, buscando uma aproximação com o que Davídov (1988) define como conhecimento teórico e conhecimento concreto, concebendo a denominação "Teórico" no sentido de superação da aparência, de conter as relações entre essência e aparência do objeto de estudo, enquanto que a denominação "Concreto" é utilizada no sentido de estar em unidade com a totalidade proposta pela atividade, ou seja, em relação com sua essência (lei universal) e com outras manifestações externas.

Referente aos aspectos socioambientais a serem abordados, consideramos tanto a realidade próxima ao aluno quanto realidades distantes que, aparentemente, não afetam sua vida, mas, ao tomar conhecimento das referidas relações, percebe que realidades distantes o afetam mais do que supunha. Esta intenção, na medida em que aspectos socioambientais são abordados, em sua relação com conceitos científicos escolares, buscam promover relações entre aspectos da ciência, tecnologia, sociedade e ambiente (CTSA), com foco nos aspectos sociais e ambientais relacionados ao conceito científico escolar, com o objetivo final de transformação da percepção do aluno sobre a realidade concreta.

Para esclarecer esta intenção da SAt, descreveremos, a seguir, 0 processo de como se deu a escolha do conteúdo químico e dos aspectos 
socioambientais, bem como as pretensões de abordagem, pois tais escolhas foram permeadas por discussões no movimento social de Educação Popular CIMEAC e no grupo de pesquisa Ciência, Compotamento e Ambiente, no sentido das possibilidades dos pontos de partida, ou seja, se optaria por definir, primeiramente, quais conceitos químicos seriam trabalhados para depois buscar os aspectos socioambientais relacionados ao conceito, ou o contrário.

Acreditamos que a aproximação entre os conceitos científicos escolares e os aspectos socioambientais, econômicos e políticos da realidade concreta correspondem, sob nosso ponto de vista sobre o ensino de ciências, à promoção das relações CTSA pretendidas, e, de acordo com nossas considerações teóricas, estas relações se dão na medida em que os alunos, ao buscarem respostas para os problemas colocados, tomam consciência dos conceitos envolvidos e, aos poucos, por um processo de internalização, ocorre a interação entre conceitos espontâneos e científicos, proporcionando:

- concretude aos científicos e sistematização aos espontâneos; sistematização dos conceitos em meio às relações de generalidade que os ligam dentro do sistema conceitual;

- significação dos conceitos por meio da aproximação entre sentido pessoal e significado e a apreensão de significações historicamente elaboradas;

- assimilação/apropriação dos conceitos ao reproduzirem as formas histórico-sociais das ações da atividade requerida pelo conceito.

Todos estes processos são mediados socialmente pela linguagem, principalmente pela fala. (VIGOTSKI, 2009; LEONTIEV, 1983, 1987; DAVÍDOV e MÁRCOVA, 1987, DAVÍDOV, 1988).

O uso de aspectos sociocientíficos (SANTOS e MORTIMER, 2009) para a promoção de controvérsias relacionadas ao contexto social do aluno, e o uso de situações-problema (VIGOTSKI, 2009), dentro de atividades de estudo (DAVÍDOV e MÁRCOVA, 1987; LEONTIEV, 2012) para guiar a abordagem dos aspectos sociocientíficos em sala de aula, foi a intenção inicial para os 
momentos de mediação dos conceitos envolvidos. É preciso ficar claro que a principal questão sociocientífica (QSC) da SAt, concernente ao uso de sementes transgênicas, unido ao uso de agrotóxicos, não teve a intenção de mediar os conceitos da termoquímica, mas de fazer parte da mediação da tomada de consciência sobre impactos ambientais da produção dos biocombustíveis. Os aspectos sociocientíficos que mediaram os conceitos da termoquímica estão relacionados ao fator econômico-pessoal e poluidor do uso dos combustíveis.

No âmbito da pesquisa em temas controversos sociocientíficos (QCS) (RATCLIFFE e GRACE, 2003; SADLER, 2004; ZEIDLER et. al, 2002 e 2005; LEVINSON, 2006; HODSON, 2009), tanto a metodologia dos trabalhos encontrados na literatura, quanto a própria definição de QCS de Sadler e colaboradores (2006), apresentam as QCS como ponto de partida ${ }^{17}$ para lançar a curiosidade e promover a busca pelos conceitos científicos tradicionais com a finalidade de se compreender questões e relações trazidas pelo tema. No entanto, é preciso perceber que se trata da forma como a proposta final é apresentada aos alunos, o que não nos dá informação de como foi elaborada, e esta etapa de elaboração das atividades, pela experiência do presente trabalho e da prática em sala de aula no projeto CIMEAC, não é uma etapa simples e merece uma descrição reflexiva se quisermos tornar acessível e compreensível esse tipo de abordagem a todos os professores e educadores.

Sabemos que a realidade na qual a maioria dos professores trabalha obedece ao currículo formal ou prescrito ${ }^{18}$, o qual prioriza os conteúdos disciplinares. Assim, tanto para aproximar a pesquisa da realidade escolar, como para manter a preocupação maior com a construção do conceito

\footnotetext{
${ }^{17}$ Reiteramos que, no caso deste trabalho, o ponto de partida teve a intenção de ser mais pessoal em relação ao aluno, partindo-se da análise de critérios para a escolha de um carro e tornando-se uma atividade de crítica ambiental permeada por QSC. No nosso caso, a apropriação de conceitos foi planejada em função de questões relacionadas à produção e uso de combustíveis pelo homem e suas consequências socioambientais, sendo a última questão generalizada para a produção e consumo de alimentos.

${ }^{18}$ Segundo Sacristán (2000), é aquele que se apresenta na organização e da distribuição das disciplinas (com os seus objetivos, conteúdos programáticos, estratégias didáticas e procedimentos de avaliação). Nele, encontra-se expresso os acordos propostos e estabelecidos por todos os participantes do seu processo de construção, influenciando o trabalho realizado na escola, a elaboração da proposta pedagógica e o planejamento do professor.
} 
científico escolar ao longo da SAt, optou-se, pela aproximação de conceitos da disciplina de química previstos no currículo escolar com o módulo temático "Energia", previsto no calendário do projeto de Educação Popular onde a SAt foi aplicada.

No entanto, esta aproximação parte primeiramente da temática do módulo Energia, no qual poderia se trabalhar diferentes formas de energia relacionadas a tecnologia, ao meio ambiente e ao contexto histórico-social do aluno, e dentre as formas de energia, a energia térmica se mostrou proprícia também por trazer a oportunidade de continuidade de abordagem de conceitos da termoquímica iniciados no módulo do semestre anterior, módulo Trabalho, no qual o conceito de combustão havia sido introduzido por meio do estudo do funcionamento da máquina a vapor de James Watt com o carvão como combustível.

Dessa forma, dentro da temática do módulo Energia seria propício darmos continuidade ao processo de formação dos conceitos de combustão e combustível, introduzindo a discussão com outros combustíveis, como o álcool e a gasolina, e introduzirmos o conceito de entalpia, compondo uma trama de sistemas conceituais da termoquímica relacionada à tecnologia do motor à combustão, o que nos levou a pensar na discussão do uso de automóveis atrelado ao uso e produção de combustíveis na sociedade/meio ambiente. Pensar o uso e produção de biocombustíveis na cidade, região de Ribeirão Preto, e para além destas, a nível nacional, trouxe a QSC do uso de sementes transgênicas da monocultura extensiva do agronegócio, a qual sabemos que está imbricada ao uso de agrotóxicos e se relaciona com a produção de alimentos. Mas este foi apenas um primeiro levantamento de possíveis conceitos químicos e relações CTSA presentes na aula.

O módulo temático desenvolvido para o mês de agosto de 2015 no projeto CIMEAC foi intitulado: "Energia: como as diferentes manifestações da energia se relacionam com os sistemas econômicos, políticos, sociais, ambientais e com as perspectivas para o século XXI". A partir deste tema e das considerações do levantamento dos conceitos químicos e relações CTSA, delimitou-se um tema socioambiental mais específico da aula de química a ser 
elaborada: "Produção e uso de biocombustíveis pelo homem", que, posteriormente, originou o título da aula: "Matriz energética brasileira: qual a parte que me cabe nesse latifúndio?". A partir deste tema e a partir da escolha do conceito de entalpia como o novo conceito a ser integrado na trama de conceitos da termoquímica, direcionamos a preparação da aula para o estudo deste conceito. Esta escolha se deve também ao fato de que o conceito de entalpia é um componente do currículo escolar do Ensino Médio e dos conteúdos cobrados no vestibular.

Partiu-se, então, para o estudo da delimitação da abordagem do conceito de entalpia, o qual envolve um amplo sistema de conceitos científicos e suas respectivas aplicabilidades dentro da química e da física. Para isso, foram consultados livros de físico-química (ATKINS e PAULA, 2008) de ensino superior e estudadas as possibilidades de abordagem do conceito para atividades em nível de Ensino Médio intencionalizadas na aula, buscando relacionar o conceito de entalpia a aspectos sociocientíficos por meio de situações-problema que desencadeassem a atividade de aprendizagem.

A delimitação ou definição do conceito de entalpia que consideramos ser apropriada para o contexto da aula, e que se aproxima da essência, lei universal que o caracteriza e o generaliza (DAVÍDOV, 1988) está relacionada à compreensão de sua variação, a qual, em condições de pressão constante em uma transição física ou transformação química, é igual a energia liberada ou absorvida pelo sistema em forma de calor, ou seja, a variação de entalpia do sistema, à pressão constante, é igual ao calor liberado ou absorvido. Dessa forma, a apropriação do conceito de entalpia, de acordo com o referencial teórico adotado, deve reproduzir as ações e operações de uma atividade que o funcionaliza, o significa, o generaliza e o concretiza. Dessa forma, entendemos que o cálculo da variação de entalpia é, em si, a reprodução histórico-social de suas características funcionais e contém a essência do conceito. Deve, pela devida mediação, tornar-se uma atividade intencional e consciente para o aluno.

No entanto, para ser intencional e não permanecer abstrato, entendemos e propomos que o conceito precisa ser mediado por meio de uma 
atividade que o motive a resolver um problema real, o qual seja possível resolver somente por meio do conceito, de forma que esse problema contenha a necessidade que gere o motivo da busca pela compreensão do conceito. Dessa forma, o cálculo de entalpia deve estar vinculado a um problema pertencente à realidade concreta do aluno e ser mediado pela mesma, o que inclui os conceitos espontâneos, empíricos, os sentidos pessoais, bem como diferentes contextos relacionados ao mesmo conceito. $O$ modo como realizamos isso dentro do tema proposto será melhor explicitado na descrição da preparação das etapas do problema.

Ainda em relação à delimitação do conceito de entalpia para a SAt, sentimos a necessidade de justificá-la em relação ao seu sistema de conceitos.

Especificamente na aula planejada para esta pesquisa, os sistemas considerados ficaram restritos à classe de sistemas químicos, contemplando as reações de combustão do álcool, gasolina e biodiesel, logo, a processos exotérmicos. O método de execução do cálculo de variação de entalpia ficou restrito ao cálculo por meio da somatória dos valores de entalpia padrão de formação.

Como todos estes processos caracterizam-se como exotérmicos, a absorção e liberação de energia como processo interno de quebra e formação de ligações e como balanço energético geral exotérmico e endotérmico deveriam ${ }^{19}$ ser trabalhados e diferenciados para evitar a falsa impressão de que a variação de entalpia se refere apenas à liberação de energia. Pelo fato das reações escolhidas serem todas de combustão, seria necessário classificálas no conjunto de entalpias de combustão e diferenciá-las dos demais tipos de entalpias de transformações químicas. Desse modo, os processos endotérmicos não foram trabalhados, bem como outras formas de entalpia, além da entalpia de combustão e entalpia de formação, mas foram mencionados em contraposição aos utilizados na SAt, já que, nosso objetivo, para este trabalho, não foi esgotar todas as formas de manifestação do

\footnotetext{
${ }^{19}$ Como este texto descreve intenções definidas no momento da elaboração da SAt, ou seja, não se referem ao que de fato ocorreu na aplicação, alguns verbos se encontram conjugados no futuro do pretérito.
} 
conceito de entalpia dentro da química, mas reproduzir sua lei universal em contexto real, pertencente a uma determinada totalidade de relações de generalidade contempladas entre o sistema conceitual e a realidade do aluno, pois concordamos com o princípio da Teoria do Ensino Desenvolvimental de que a apropriação da essência do objeto de estudo supera a sua aparência e dá suporte ao aprendiz para operar com o conceito em novos contextos. (DAVÍDOV, 1982 apud LIBÂNEO; FREITAS, 2013, p. 335). O mesmo vale para o cálculo de variação de entalpia.

As reações de combustão dos combustíveis trabalhados em nossa SAt (álcool, gasolina e biodiesel) possuem um padrão geral de funcionamento, de condições para a ocorrência do fenômeno, e da natureza dos reagentes e produtos envolvidos, compostos principalmente por carbono, hidrogênio e oxigênio, guardando, como lei universal do conceito de combustão, a necessidade da interação entre combustível, comburente e energia de ignição, para resultar, de maneira geral e completa, nos produtos água e dióxido de carbono. No entanto, a natureza do combustível, principalmente, determina variações dos produtos formados, abrindo o "leque" da variedade de produtos, como os diversos poluentes derivados das diferentes composições dos combustíveis.

Estes poluentes seriam uma oportunidade de relação com os aspectos ambientais, no entanto, em vista de focalizar o trabalho no conceito de entalpia, a existência dessas variações, como liberação de compostos de enxofre, hidrocarbonetos e outros, seriam apenas mencionadas, os exemplos utilizados em aula abordariam somente as combustões completas e incompletas (liberação de dióxido e monóxido de carbono, respectivamente, e água), e os cálculos seriam baseados somente nas combustões completas do álcool, gasolina e biodiesel, sem a presença de subprodutos, o que posteriormente dirige e foca a discussão para a renovabilidade do combustível.

Como os conceitos e representações simbólicas de reação de combustão e de balanceamento já foram introduzidas aos alunos em aulas anteriores a esta, considerando, portanto, o movimento do processo da 
formação de conceitos, esperávamos que o conceito de reação de combustão tivesse seu processo de formação continuado nessa aula.

Para o cálculo da variação de entalpia, nas reações de combustão, foram considerados exclusivamente os dados de entalpia padrão de formação, desprezando-se outras formas de cálculo. A opção pela priorização de apenas uma das formas de cálculo justifica-se pela aproximação com o princípio davidoviano sobre o suporte dado pela essência do conceito em outros contextos, da limitação temporal da aula, e pela maior possibilidade de observação de um mesmo procedimento de cálculo realizado por diferentes grupos de estudantes.

Como um dos instrumentos para mediar o cálculo de variação de entalpia, foi elaborada uma tabela com os valores de entalpia padrão de formação de todas as substâncias envolvidas nos reagentes e produtos das reações, disponibilizada para a consulta dos alunos (apêndice A). Assim, o próprio conceito de entalpia padrão de formação poderia ser diferenciado da entalpia padrão de combustão e o conceito de "padrão" poderia ser explicado no sentido de promover aspectos da natureza da ciência, no sentido de como os padrões são desenvolvidos. Nesse caso, a condição padrão se refere à pressão constante de 1 Bar e à substância pura no seu estado de referência (estado de maior estabilidade do elemento) para a formação da substância cujo valor de entalpia padrão se encontra na tabela 1, apêndice A.

A entalpia padrão de formação seria considerada como uma forma organizada de valores de base para o cálculo da variação de entalpia de outras reações, entendida como um banco de dados elaborado sócio-historicamente, de forma padronizada e internacionalizada pela comunidade científica, assim como suas unidades de medida em Kilo Joule por mol (KJ. mol-1). Sob a perspectiva histórico-cultural, a entalpia padrão de formação seria mais um instrumento de mediação para a internalização do cálculo de entalpia de combustão, e também um conceito cuja formação teria continuidade.

No exercício de elaboração da SAt, o estudo das possibilidades de delimitação de um conceito químico a ser trabalhado foi um exercício de escolhas, direcionado pelo limite temporal da aula, contexto histórico-social dos 
alunos, objetivo de apropriação dos conceitos químicos em meio a este contexto histórico-social, e atributos do conceito químico, entendidos aqui como características externas e internas, e funções do conceito, que escolhidos para a sua abordagem, sua delimitação, ao atenderem os objetivos de promoverem as relações CTSA, podem proporcionar a linha de raciocínio da aula.

Existem atributos do conceito químico que são, por si só, as relações diretas com o contexto socioambiental, estabelecendo a unidade entre 0 sistema conceitual do conteúdo da disciplina de química abordado em aula e o contexto social do aluno. Assim, no planejamento dessas relações, podemos percorrer o caminho que parte do tema "Produção e uso de combustíveis pelo homem", e, a partir desse contexto, iniciarmos o desenvolvimento do conceito químico abstrato em meio a contextos sociais que, em etapas, focam aspectos econômicos, aspectos socioambientais, aspectos sociais do trabalho, da saúde e da política, todos buscando a unidade entre os conceitos químicos e o contexto social dos alunos.

Traçadas estas relações, partiu-se para a delimitação das mesmas em função do tema da aula, do problema e questões a serem colocadas para os alunos. O motivo inicial foi estabelecido na tentativa de dar um sentido pessoal para a resolução do problema e discussões das questões. Também foi levado em consideração as aulas anteriores, da mesma semana, nas quais foi introduzido aos alunos o conceito matemático de matriz. Dessa forma, como consta no apêndice $A$, a introdução da nossa aula contemplou uma breve retomada de alguns atributos do conceito de matriz sob a perspectiva de matriz energética brasileira.

A partir do conjunto de fontes de energia que compõem a matriz energética brasileira, seria levantada uma discussão sobre energias renováveis e não renováveis, focando, em seguida, os combustíveis e a "nossa" relação com os mesmos, isto é, o reconhecimento de como o homem consome combustíveis, incluindo os setores comercial e industrial, de forma que a condução da professora incluísse, aos poucos, o aluno nessa relação históricosocial. 
Após essa discussão, seria proposta uma situação hipotética para que o conjunto de questões que compõem a atividade, relacionado à produção e consumo de combustíveis pelo homem, contemplasse, também, um motivo ligado à vida do aluno em sua relação com a sociedade, considerando seu contexto histórico-social. Optou-se por um conjunto de reflexões relacionadas a escolha de um carro, como consta no texto introdutório do apêndice $A$ e no item 2 deste documento, por apresentar a atividade a partir da elaboração de uma reflexão que guiasse as ações da atividade até a conclusão da aula.

A discussão inicial baseada no texto introdutório levaria à atividade da aula: pensar a escolha de um carro sob vários pontos de vista, levantando critérios inicialmente pessoais de escolha e considerando as opções reais disponíveis no mercado. Um carro de passeio, que atendesse suas necessidades como cidadão, sendo que estas necessidades poderiam ser pensadas hipoteticamente, como projeções futuras esperadas para sua vida, envolvendo anseios e responsabilidades, incluindo a utilização do carro, intercalada a outros meios de transporte.

Desse modo, pensar em critérios de compra de um carro estaria ligado a uma escolha pessoal e a uma tomada de decisão diante das opções disponíveis no sistema produtivo e mercadológico em que o aluno estaria inserido, o que, aos poucos, implicaria e se transformaria em um estudo crítico deste contexto histórico-social.

A atividade, como um todo, deveria promover questões que gerassem a necessidade do uso de conceitos, tais como: reação química, reação de combustão, balanceamento de reações químicas, combustível, calor, energia, entalpia e cálculo de entalpia, contribuindo para o desenvolvimento desses conceitos. A necessidade do uso desses conceitos não seria a-histórica, já que consideramos a SAt proposta inserida no contexto histórico-social do aluno ${ }^{20}$.

\footnotetext{
${ }^{20}$ Vale relembrar que a reprodução da necessidade lógico-histórica não exige que o processo histórico original seja reproduzido com os alunos, sendo esta via uma opção (MOURA e COLABORADORAS, 2010). O importante é que o problema proposto reproduza a necessidade de sistematização e apropriação do conceito. Esta lógica metodológica pode ser encontrada no trabalho de Moura e Lanner de Moura (1998) com a abordagem de jogos, situações emergentes do cotidiano e histórias virtuais.
} 
Além disso, a atividade deveria promover relações CTSA ao longo das discussões da aula, buscando relacionar os conceitos químicos a fatores do contexto socioambiental do aluno, tais como: poluição, renovabilidade do combustível, tecnologias utilizadas para a produção dos biocombustíveis (transgenia de plantas, agrotóxicos) e sistema agroflorestal. Dessa forma, desejávamos a tomada de consciência e a relação entre conceitos científicos escolares e aspectos sociais, econômicos, ambientais e políticos pertencentes à realidade concreta do aluno, em nível de Brasil, incluindo o aluno como sujeito-histórico ativo nessa realidade.

Dentre os critérios a serem levantados pelos alunos para a compra de um carro, eram esperados dois, especificamente, para serem trabalhados na aula e relacionados ao conceito de entalpia: fator econômico relacionado ao desempenho do motor, e escolha entre combustível renovável ou não renovável relacionada com a poluição. Além desses dois critérios, seria abordado, nas discussões, as condições de produção do álcool e do biodiesel em larga escala, relacionando, posteriormente, essas condições de produção, à produção de alimentos em larga escala, de modo que o conceito de entalpia fosse explorado nas reações de combustão de veículos automotores e, também, identificada na reação de combustão da respiração celular, a qual tem como combustível a glicose ingerida na alimentação.

Estes contextos permitiriam estabelecer relações CTSA, explorando discussões socioambientais, tecnológicas, políticas e econômicas relacionadas ao consumo de combustíveis e alimentos, os quais se inserem no contexto histórico-social do aluno, resultando em consequências (como o consumo de alimentos transgênicos com agrotóxicos), que, posteriormente, seriam foco de tomada de consciência por parte dos alunos.

Para o leitor ter um panorama geral das ações planejadas para a atividade proposta aos alunos, ilustramos esta atividade na figura $2^{21}$, em função do motivo inicial da atividade de ensino-aprendizagem (escolha de um carro) e das ações que a constituem. Estas, no processo de mediação pela

\footnotetext{
${ }^{21}$ A figura 2 está localizada na p. 120, por questão de disponibilização do espaço.
} 
professora e apropriação dos problemas pelos alunos, tornam-se atividades de aprendizagem motivadas por necessidades relacionadas a problemas reais do contexto social do aluno, além de permanecerem relacionadas ao motivo inicial. O diagrama da figura 2 apresenta, também, as ações que derivam de ações anteriores.

Voltando à proposta aos alunos de que levantassem critérios para a escolha de um carro, o critério relacionado à economia do motor seria abordado em função da escolha do combustível, tendo acordado com os alunos fixar determinada potência do motor, como o motor 1.0.

A partir dessas condições, a primeira etapa da atividade (item 1 do item "O Problema", apêndice A), seria colocada de forma a levantar a situaçãoproblema: como saber qual combustível compensa mais economicamente? Assim, seria solicitado para que o aluno verificasse a origem do rendimento do motor e qual combustível seria mais econômico, comparando-se álcool e gasolina. O objetivo dessa situação-problema é levar os alunos a pensarem na energia liberada pelo combustível como origem do rendimento do motor e sua consequente influência sobre o preço, de modo a possibilitar a apropriação do conceito de entalpia por parte do aluno por meio de seu cálculo, visando à obtenção dos valores de energia e a comparação dos mesmos. 
Figura 2: Panorama geral da Sequência de Atividades (SAt).

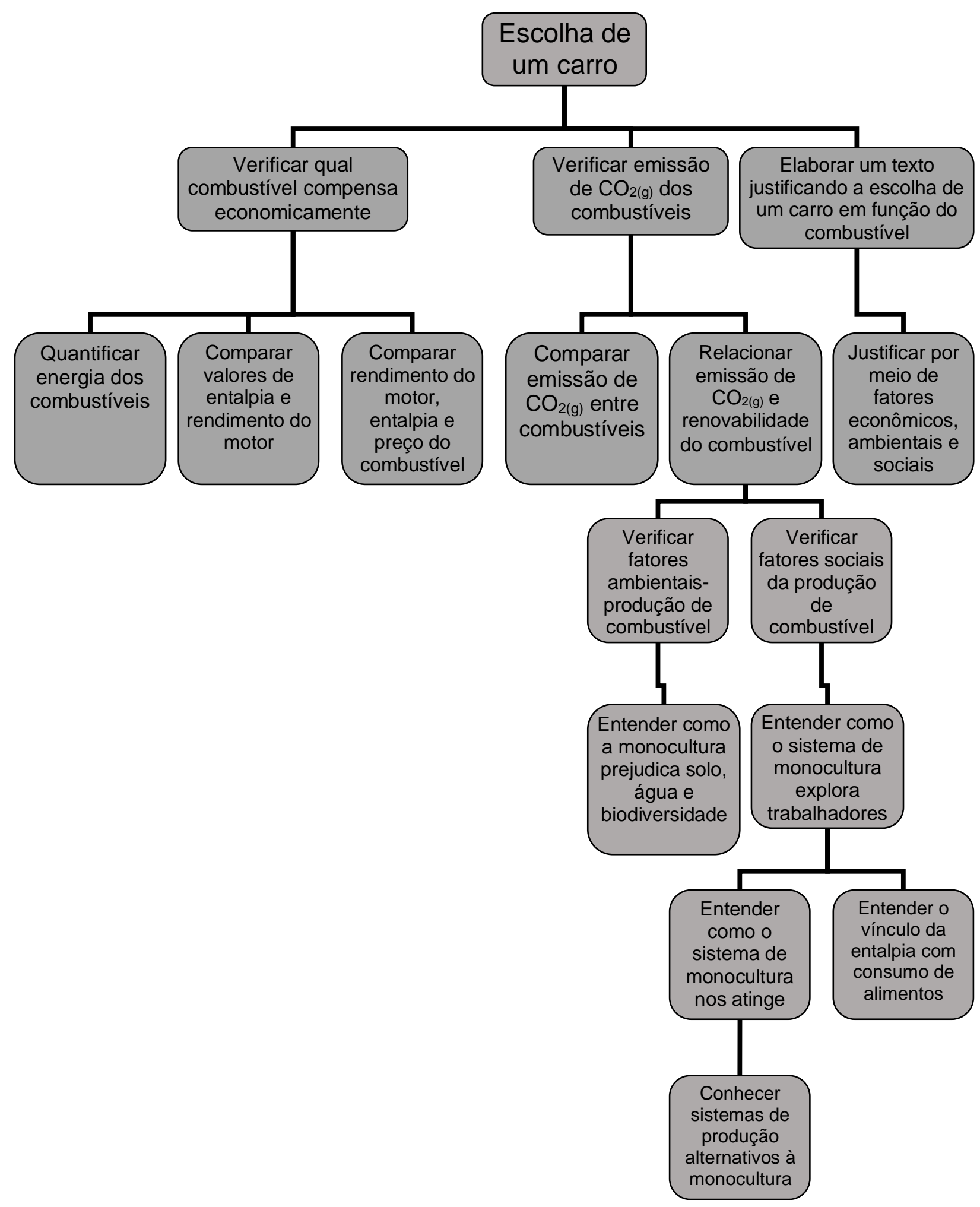

Fonte: Schneider-Felicio (2018).

De acordo com a fundamentação teórica adotada, entendemos e propomos, com esta primeira situação, que, se um dos critérios escolhidos para 
a compra de um carro é sua economia, a preparação da atividade de estudo pelo professor deve buscar unir a necessidade da atividade com o objeto de estudo, o que só se torna possível por meio da mediação do professor na condução do problema. Assim, temos:

Motivo inicial da atividade de ensinoaprendizagem: escolha de um carro

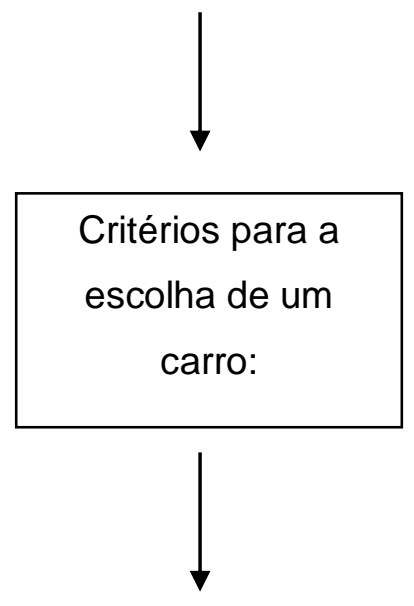

Necessidade/motivo:

o carro deve ser econômico

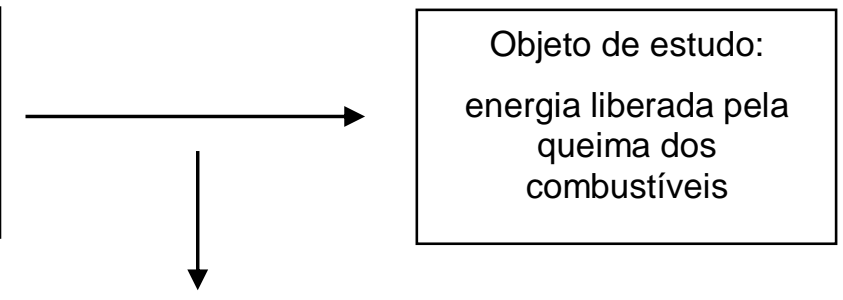

$$
\begin{gathered}
\text { Mediação do } \\
\text { professor }
\end{gathered}
$$

Necessidade/motivo: cálculo da entalpia de combustão
Objeto de estudo: entalpia de combustão 
A mediação do professor ${ }^{22}$ deve direcionar o aluno para a verificação do fator econômico do carro por meio da comparação entre as energias liberadas nas reações de combustão do álcool, gasolina e biodiesel, de forma que a necessidade de o carro ser econômico em função do combustível gera o motivo da ação, ou seja, o motivo para o cálculo de entalpia. Este, por sua vez, acompanha uma necessidade que coincide com o objeto de estudo, gerando o motivo da ação de reprodução das formas de ação dessa atividade (o cálculo de entalpia). O cálculo de entalpia passa a ser, então, uma atividade intencional e consciente, motivado pela sua necessidade dentro da atividade de verificação sobre qual combustível é mais econômico.

De acordo com a apresentação dos princípios da teoria das ações mentais de Galperin (NÚÑEZ, 2009, p. 94), o conhecimento teórico existe sempre relacionado à reprodução das ações, sendo conhecimento em ação. Assim, entendemos que os conceitos não podem ser formados sem as ações que proporcionam seus papéis, suas funções. No caso da entalpia de combustão, tomamos sua definição como a energia liberada pela reação de combustão à pressão constante. O domínio dessa definição implica em aplicála em tipos específicos de atividade, no caso, o cálculo de variação de entalpia.

Este princípio do conceito em ação vem complementar o que Vigotski (2009) coloca sobre o conceito não ser tomado em seu sentido estático e isolado, mas nos processos de solução do problema, de modo que "toda a investigação se divide numa série de etapas particulares, cada uma das quais incorpora os conceitos, nessa ou naquela aplicação aos processos de pensamento." (p.165).

De acordo com Leontiev (2012), as atividades são processos psicológicos que satisfazem uma necessidade específica do sujeito, dirigidas, como um todo, a um objeto, que coincida com o objetivo que estimula o sujeito a executar as ações que compõem a atividade - o motivo que deriva da necessidade. Envolvem emoções e sentimentos. $O$ autor distingue ação e atividade, pois o ato ou ação é um processo cujo objetivo não coincide com o

\footnotetext{
22 Não estamos negando a mediação do professor nos momentos anteriores, a qual, como poderá ser observado nas falas transcritas, perpassa toda aula, e, juntamente com a fala dos alunos, é o principal instrumento de mediação utilizado na aplicação da SAt.
} 
motivo da atividade, mas reside na atividade. Nas palavras de Leontiev, "o objetivo de uma ação, por si mesma, não estimula a agir. Para que a ação surja e seja executada, é necessário que seu objetivo apareça para o sujeito, em sua relação com o motivo da atividade da qual ele faz parte" (p. 69). Assim, o objeto de uma ação é seu alvo direto, não o motivo da atividade, mas mantém certa relação com este.

No entanto, uma ação pode se transformar em uma atividade na medida em que o motivo desta é transferido para o objetivo da ação. Ou, o objetivo da ação se torna um motivo para o sujeito, transformando a ação em uma atividade de práxis. Segundo Leontiev (2012, p. 69), "Esta é a maneira pela qual surgem todas as atividades e novas relações com a realidade".

No nosso caso, a atividade se inicia motivada pela escolha de um carro. Este motivo gera a ação de levantamento de critérios, sendo, o primeiro, sua economia. A necessidade de o carro ser econômico continua relacionada ao motivo inicial e é direcionada por meio da mediação da professora para a ação de verificação de qual combustível compensa mais economicamente. Para que esta ação seja concretizada pelos alunos, o cálculo da variação de entalpia se torna uma necessidade diretamente ligada ao objeto de estudo, gerando o motivo da concretização da ação do cálculo. Assim, o motivo da escolha de um carro passa para a necessidade de o mesmo ser econômico, que, por mediação, gera a necessidade e motivo da ação para o cálculo de entalpia. Da mesma forma, a atividade de levantamento de critérios para a escolha de um carro torna-se a atividade de verificação de sua economia, que, por sua vez, torna-se a atividade de cálculo de variação de entalpia, em um movimento que partiu do concreto aparente, em direção ao sistema abstrato de conceitos da termoquímica, em um movimento em que os conceitos espontâneos do aluno proporcionam concretude aos conceitos científicos da termoquímica e em que os sentidos pessoais são direcionados para o encontro com os significados dos conceitos químicos.

Para realizar o cálculo de variação de entalpia, o aluno necessita se apropriar do modo de ação, dos instrumentos simbólicos que o representam e representam o conceito, gerando novas ações e operações que concretizarão 
as atividades do cálculo de variação de entalpia, a posterior comparação entre as energias liberadas pelo álcool e gasolina, a posterior comparação com o rendimento dos motores e com o preço dos combustíveis, até a objetivação da atividade de verificação de qual combustível compensa mais economicamente, em um movimento no qual os conceitos científicos sistematizam os conceitos espontâneos e no qual os significados transformam os sentidos, completando o movimento de retornar à realidade concreta, agora complexificada.

A comparação entre a energia liberada pelo álcool e pela gasolina deve ser relacionada à comparação dos rendimentos dos motores para que os alunos percebam que o combustível que libera mais energia tem maior rendimento de motor, ou seja, percorre maior distância com um litro de combustível. Por sua vez, os rendimentos dos motores, fornecidos em tabelas para os alunos (apêndice A, tabela 2), ao serem comparados aos preços dos combustíveis, permitem levar a uma demonstração matemática de que a impressão de que o álcool é mais barato é falsa, e levar a uma discussão sobre o preço que o consumidor paga por esses combustíveis. A tabela 2, do apêndice $A$, fornece os preços reais da ocasião para o álcool e a gasolina.

É importante perceber os limites dessa discussão, pois fatores como valor da entalpia e rendimento do motor não estão diretamente relacionados por estes dados e isso deve ficar claro para o aluno. Existem outros fatores de funcionamento do motor que influenciam em seu rendimento, os quais não foram estudados, apenas apontados na discussão como existentes. A comparação de rendimentos apenas entre álcool e gasolina se deve ao funcionamento semelhante desses motores, por isso, o biodiesel não entra nesta comparação, o que não impede que o valor energético de sua combustão seja observado teoricamente. Neste caminho, o principal objetivo foi que, a partir do conceito químico, o fator econômico do rendimento e preço final do combustível pudesse ser discutido, de modo a demonstrar que uma propriedade físico-química também contribui para o valor de mercado do combustível. Consideramos esta a primeira relação de natureza CTSA entre conceitos químicos e o contexto histórico-social do aluno. 
O aluno precisa representar e balancear a reação de combustão, utilizar as tabelas de entalpia padrão de formação das substâncias envolvidas e calcular a entalpia de combustão de cada combustível para, depois, comparálas, atentando para a natureza do sinal negativo dos valores, significando a liberação de energia. A posterior comparação dos valores de energia e rendimento dos respectivos motores é feita por meio de consulta a valores tabelados de rendimento de motor, e a constatação de que o álcool não é mais barato que a gasolina é feita por cálculos de razão e proporção, nos quais se compara, primeiramente, a razão ou porcentagem entre os rendimentos dos motores a álcool e a gasolina para, posteriormente, verificar se a diferença de preço entre álcool e gasolina acompanha a mesma razão, se é maior ou se é menor. O professor deve indicar ou fornecer as formas de ação dos conceitos necessários para o aluno percorrer este caminho, conforme suas necessidades.

A fim de ilustrar as ações que compõem esta primeira etapa da sequência de atividades, a qual também consideramos uma ação transformada em atividade, elaboramos a figura 3.

Figura 3: Detalhamento das ações que constituem a primeira atividade com situaçãoproblema da sequência de atividades.

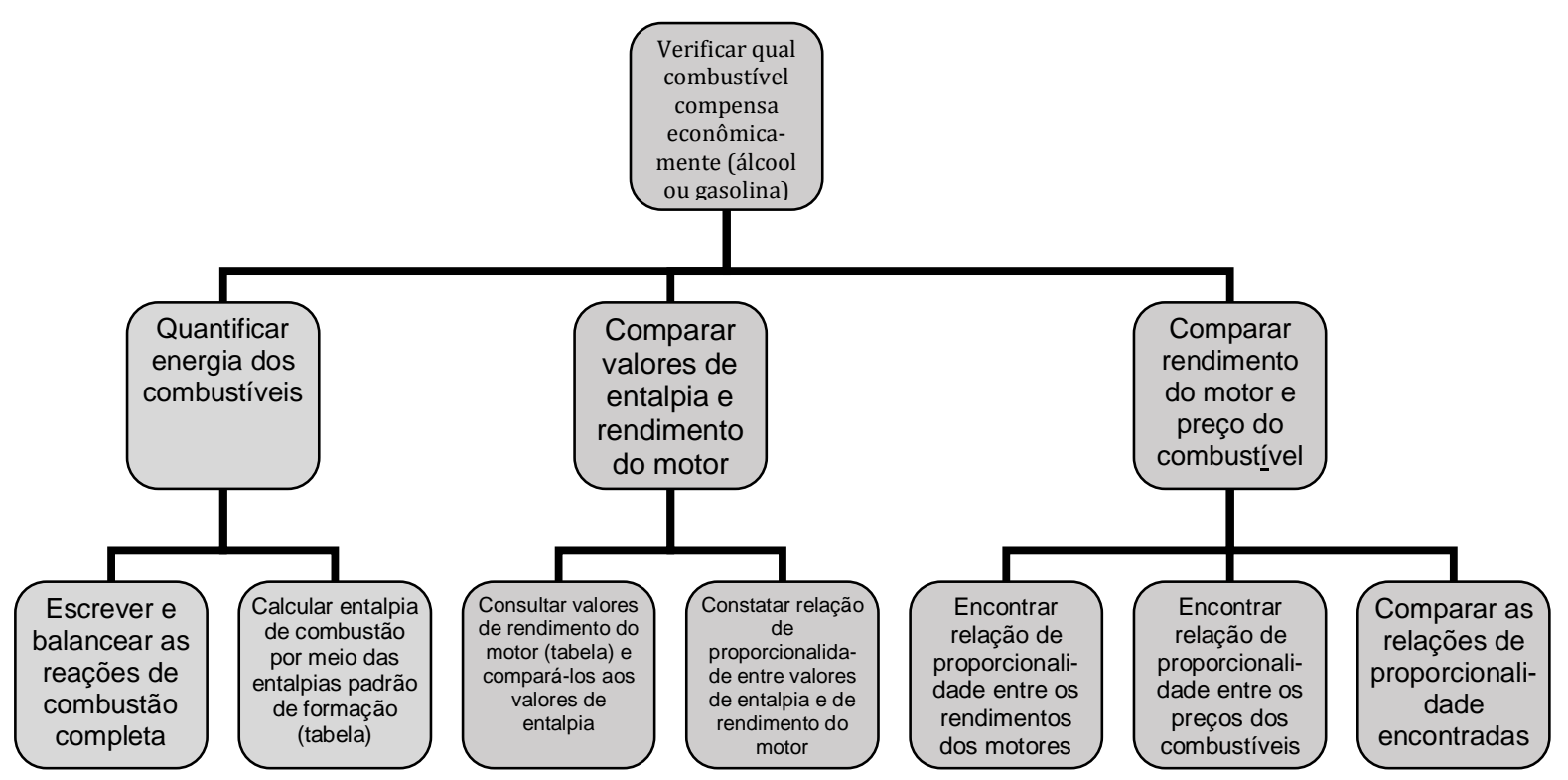

Fonte: Schneider-Felicio (2018).

Esperou-se que "Verificar qual combustível compensa economicamente" tenha assumido o papel do motivo da atividade, na qual o aluno entra no 
momento em que se concentra em responder às questões: "Qual combustível compensa mais economicamente?" e "De onde vem o desempenho energético do combustível? Como posso calculá-lo?" (item 1, do item "O Problema", apêndice A). Estas últimas questões indicam as condições de partida, por meio das quais os alunos tomaram a energia de combustão por base de comparação, primeiramente, com o rendimento do motor e, posteriormente, deste com o preço dos combustíveis; comparações que se tornaram as novas ações da atividade.

As condições vinculadas à quantificação da energia do combustível levam a novas operações, como escrever e balancear a reação de combustão e calcular a entalpia de combustão, como mostra o diagrama da figura 3. Estas operações, no momento em que se tornam foco da atividade do aluno, assumem o papel de ações da atividade, gerando novas operações, tais como: busca por valores de entalpia padrão de formação ${ }^{23}$ em tabela, operações de somatória, bem como operações de tentativa e erro, multiplicação e divisão para o balanceamento da reação. Semelhantemente, as condições vinculadas à comparação entre valores de entalpia e rendimento do motor e à comparação do rendimento do motor com os preços dos combustíveis levam a novas operações, descritas no terceiro nível do diagrama da figura 3.

Ao tomar consciência dessas operações, as mesmas podem se tornar ações da atividade ao levarem o aluno a realizar novas operações, como cálculos de razão e porcentagem, soma, subtração, divisão e multiplicação, não descritas no diagrama. Estas transformações em que o motivo passa para a ação, transformando-a em atividade, indicam o movimento dialético da atividade de aprendizagem (DAVIDOV e MARCOVA, 1987) e correspondem aos momentos em que as ações do segundo nível do diagrama da figura 1 se tornam motivos. Se considerarmos as ações da atividade como motivos das operações, estas se tornam ações e dão origem a novas operações, como representado no diagrama da figura 3.

\footnotetext{
${ }^{23}$ O cálculo de entalpia de combustão foi realizado a partir de valores tabelados das entalpias padrão de formação dos reagentes e produtos envolvidos nas reações de combustão completas do álcool e da gasolina.
} 
Figura 4: $1^{\underline{a}}$ etapa da sequência de atividades (SAt).

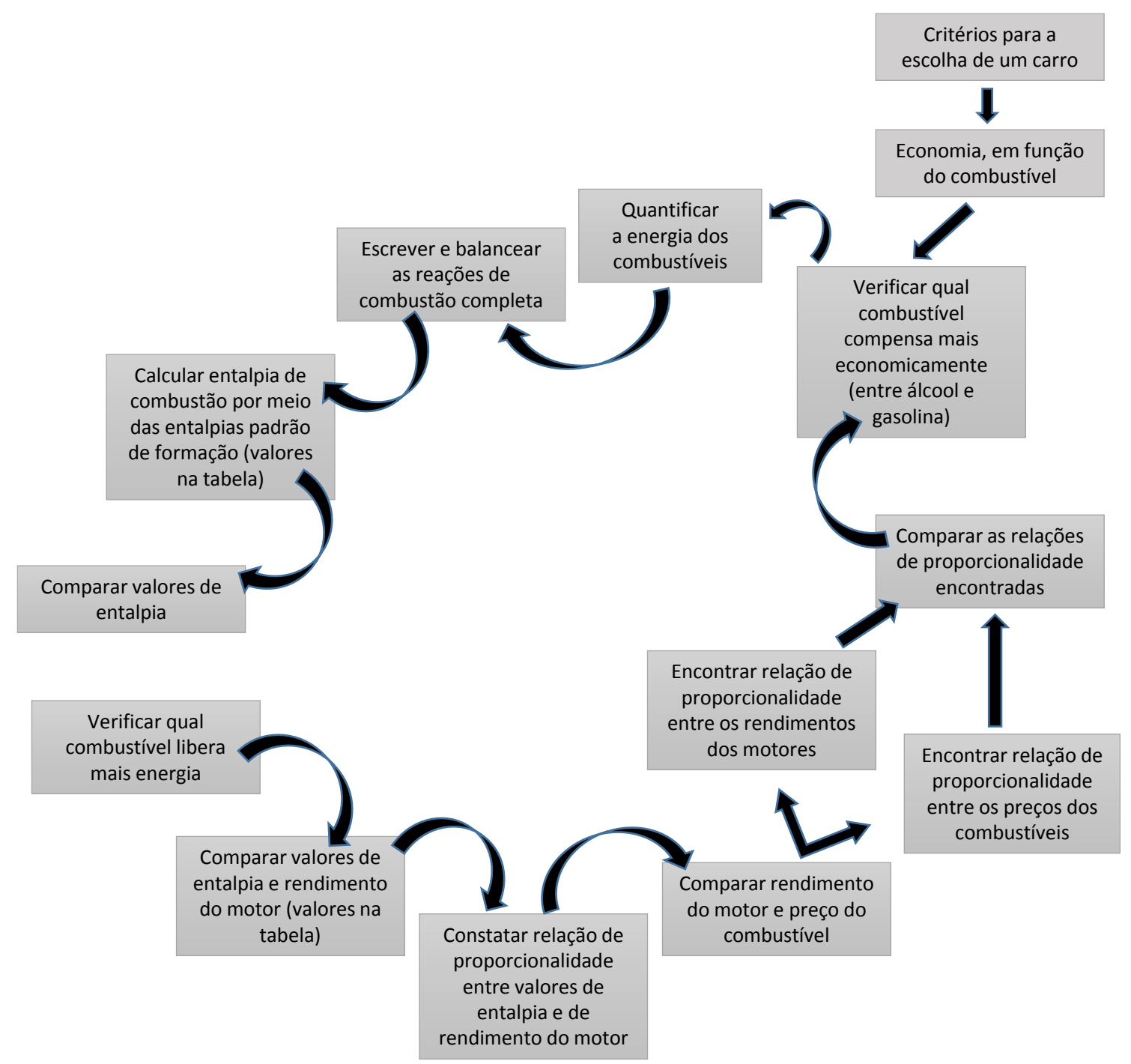

Fonte: Schneider-Felicio (2018).

A figura 4 representa o movimento das ações da atividade de verificação da economia do carro em função do combustível. Consideramos que a mesma se configura como uma atividade de estudo a ser apropriada e reproduzida pelo aluno. Consiste em um problema que só pode ser concretizado pelo aluno com a ajuda de seus pares e do professor e contém um complexo sistema de relações entre o conhecimento interno e externo sobre o conceito de entalpia, nos limites do contexto social proposto. 


\subsubsection{Segunda etapa da sequência de atividades}

A segunda etapa da SAt (item 2 do item "O Problema", apêndice A) remete-se ao critério de escolha do carro relacionado à poluição, mais especificamente à emissão de $\mathrm{CO}_{2(\mathrm{~g})}$ em função do combustível.

Primeiramente, colocamos que a intensão em tratar o $\mathrm{CO}_{2(\mathrm{~g})}$ como poluente não se reduz a desconsiderar o seu importante papel no ciclo do carbono, sua função na renovabilidade dos combustíveis, na respiração e crescimento da biomassa, mas a considerar as reações de combustão simplificadas que os alunos estão trabalhando e chamar a atenção para a característica do $\mathrm{CO}_{2(\mathrm{~g})}$ de retenção de calor associada a um hipotético aumento de sua concertração na localidade de Ribeirão Preto. Em segundo lugar, o conceito de poluição não é restrito apenas ao tipo de substância, mas à sua função e quantidade/concentração em interação com determinado ambiente, que forma que uma substância pode ou não ser poluente, dependendo de condições como estas.

Assim, nesta etapa da SAt coloca-se a situação-problema: como saber qual seria o combustível menos poluente em relação à: a) emissão de $\mathrm{CO}_{2(\mathrm{~g})} \mathrm{e}$ b) renovabilidade?

A intenção dessa questão seria que os alunos voltassem a observar as reações de combustão completa já trabalhadas, mudando-se o foco para a comparação da quantidade de dióxido de carbono liberada na queima de um mol de cada combustível. Dentre as diversas formas de abordagem possíveis (como calcular o volume de $\mathrm{CO}_{2(\mathrm{~g})}$ liberado em litros), optou-se somente pela observação dos coeficientes de balanceamento de equação. Esta observação tinha como objetivo reforçar o entendimento dos coeficientes molares já utilizados no cálculo de entalpia para o entendimento de sua influência nos valores de entalpia, agora para a reflexão sobre a quantidade de gases poluentes emitidos.

Assim, os conceitos de balanceamento e quantidade de matéria, pertencentes ao sistema de conceitos necessários ao entendimento do conceito de entalpia, possuem relação direta com o aspecto socioambiental da 
poluição do ar pelo uso de combustíveis, facilitando a promoção de relações de generalidade (VIGOTSKI, 2009) entre os conceitos químicos, e entre estes e os aspectos ambientais envolvidos como a segunda relação de natureza CTSA. Considerou-se como poluição a emissão de $\mathrm{CO}_{2(\mathrm{~g})}$ relacionada à intensificação do aquecimento global e possíveis influências no microclima da cidade. As questões controversas (QSC) do aquecimento global não seriam aprofundadas nesta aula.

Aqui, a necessidade da questão é de que o combustível seja o menos poluente, em função dos itens "a" e "b". Em "a", a necessidade de que o combustível libere menor quantidade de $\mathrm{CO}_{2(\mathrm{~g})}$ deve gerar o motivo da ação de verificação e comparação da emissão de $\mathrm{CO}_{2(\mathrm{~g})}$ dos combustíveis por meio dos coeficientes estequiométricos da reação de combustão. O que deve ser direcionado pela mediação do professor. Assim, temos:

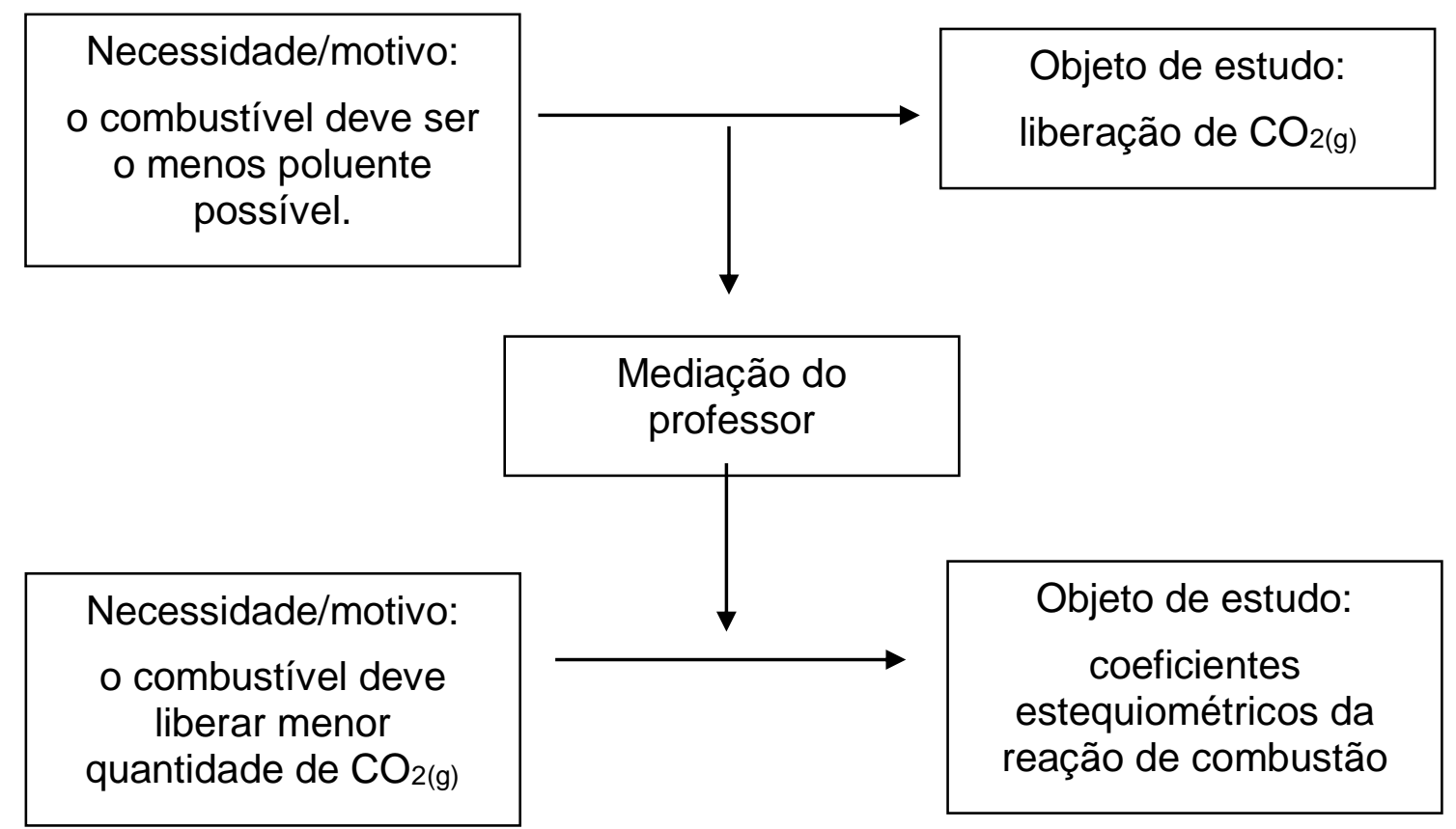

Por meio da mediação do professor, a necessidade de o combustível ser o menos poluente se mostra em função da liberação de $\mathrm{CO}_{2(\mathrm{~g})}$ e direciona a necessidade para que o combustível menos poluente seja o que libera menos $\mathrm{CO}_{2(\mathrm{~g})}$. Esta necessidade deve coincidir com o objeto de estudo, que no caso é o conceito químico que o professor pretende focar: os coeficientes estequiométricos da reação de combustão do álcool, gasolina e biodiesel, o que só é possível por meio da mediação do professor. Dessa forma, a 
necessidade da verificação sobre qual combustível libera menos $\mathrm{CO}_{2(\mathrm{~g})}$ coincide com o objeto de estudo, gerando o motivo da ação de observação e comparação dos coeficientes estequiométricos que acompanham o $\mathrm{CO}_{2(\mathrm{~g})}$ nas reações de combustão do álcool, gasolina e biodiesel. A comparação das reações e dos coeficientes estequiométricos passa a ser uma atividade intencional e consciente, mantida pelo motivo de verificar qual dos combustíveis libera menos $\mathrm{CO}_{2(\mathrm{~g})}$.

Ao comparar as quantidades de dióxido de carbono liberadas pelo álcool, gasolina e biodiesel, essa relação pode ser explorada, de forma que os aspectos sociocientíficos comecem a ganhar espaço na discussão. Ao passo que o aluno observa que a quantidade de $\mathrm{CO}_{2(\mathrm{~g})}$ liberado pelo biodiesel é, de longe, a maior, espera-se que ocorra uma tomada de consciência sobre os problemas socioambientais de seu contexto social, a partir de uma ruptura de expectativa, uma contradição em relação à qualidade de biocombustível, ou combustível "limpo", ou energia "limpa", amplamente atribuída para o biodiesel.

Uma discussão sobre uma hipotética substituição por biodiesel em todos os carros da cidade poderia ser feita para se pensar nas possíveis consequências, considerando que Ribeirão Preto possui temperaturas elevadas durante a maior parte do ano e se localiza em uma antiga depressão vulcânica. Dessa forma, a partir de um dado químico qualitativo e quantitativo, observa-se possíveis consequências ambientais, locais e globais. O conceito de energia limpa presente no senso comum começaria a ser desconstruído pelos próprios dados da reação de combustão do biodiesel, e o significado do balanceamento da reação química seria generalizado para um contexto social, contribuindo para a transformação da percepção sobre a realidade por tomada de consciência.

Da comparação da emissão de $\mathrm{CO}_{2(\mathrm{~g})}$ pelos combustíveis também deriva a discussão sobre a renovabilidade dos biocombustíveis em detrimento da não renovabilidade dos combustíveis fósseis, de forma a abordar aspectos relacionados ao ciclo do carbono. Neste momento, coloca-se o item "b" sobre a análise da poluição dos combustíveis em função da renovabilidade. 
Voltando aos critérios de escolha de um carro, o critério de que o carro utilize o combustível menos poluente, em "b", deveria ser vinculado à necessidade de que o combustível seja renovável. Esta necessidade deveria gerar o motivo da ação de verificação da existência do caráter renovável nos combustíveis por meio do conceito de renovabilidade, direcionado pela mediação do professor. Assim, temos:

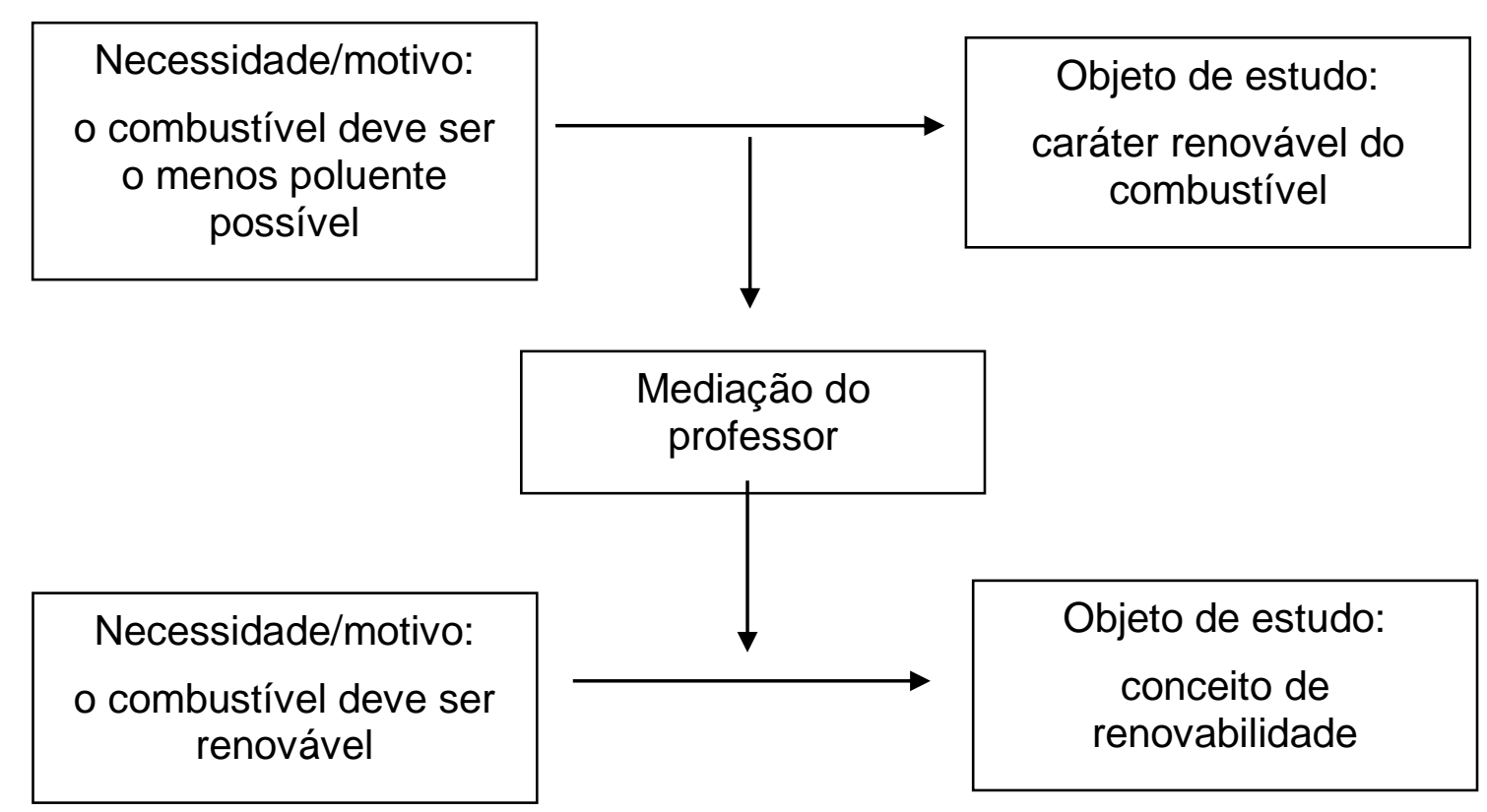

Por meio da situação-problema "b" e da mediação do professor, a necessidade de o combustível ser o menos poluente coincide com o caráter renovável do mesmo. A mediação do professor direciona à necessidade de o combustível ser renovável. Para satisfazer esta necessidade, é preciso verificar qual combustível é renovável, o que só é possível por meio da aplicação do conceito de renovabilidade aos combustíveis. O álcool é renovável? A gasolina 
é renovável? O biodiesel é renovável? Esta aplicação do conceito de renovabilidade aos combustíveis é a ação de verificação de qual combustível é renovável, gerada pelo motivo da necessidade de o combustível ser renovável, logo, ser menos poluente. Desta forma, esta verificação torna-se uma atividade intencional e consciente.

Aqui, o professor deve conduzir uma discussão que inter-relaciona a liberação de $\mathrm{CO}_{2(g)}$ pelos combustíveis e o conceito de renovabilidade. Neste processo, os alunos vão assimilando o conceito de renovabilidade em função dos conceitos de biocombustíveis e combustíveis fósseis, os quais servem como instrumentos para a assimilação do conceito de renovabilidade. Tudo isso, dentro da atividade de verificação sobre quais combustíveis são renováveis, logo, menos poluentes.

Apesar do biodiesel liberar grande quantidade de $\mathrm{CO}_{2(\mathrm{~g})}$, o caráter renovável do combustível permite a reincorporação desse gás durante 0 crescimento da planta por meio da fotossíntese. Nesta discussão, os combustíveis renováveis podem ser comparados aos combustíveis não renováveis para que a discussão sobre o ciclo do carbono se complete nos limites da discussão dos combustíveis envolvidos na aula, não deixando de mencionar a existência de mais seres vivos e fatores naturais ou antrópicos envolvidos no ciclo do carbono.

Espera-se que a ideia de renovabilidade dos biocombustíveis os influencie a optar pelo álcool e descartar a gasolina por não ser renovável. Como o biodiesel não é disponível no mercado popular, as discussões são paralelas e hipotéticas. Nesse momento, o biodiesel deve ser entendido como um biocombustível de renovabilidade semelhante ao álcool. A ideia de combustível renovável deve soar reconfortante aos alunos, para que a próxima discussão cause desconforto e os façam repensar a escolha pelo uso do etanol em seu suposto carro.

\subsubsection{Terceira etapa da sequência de atividades}

Na terceira etapa do problema, a escolha de um carro continua em função do combustível a ser utilizado, porém, passaremos da análise crítica do 
uso desses combustíveis para a análise crítica da produção desses combustíveis, ou seja, a análise crítica do sistema produtivo à base de monocultura extensiva, que, no Brasil, ainda se utiliza única e obrigatoriamente do pacote: sementes transgênicas e agrotóxicos. No entanto, neste momento da sequência de atividades, espera-se que a maioria dos alunos esteja confortável com a ideia de os biocombustíveis serem renováveis, para que a questão sociocientífica ou controvérsia sociocientífica (QSC) sobre o uso de sementes transgênicas e agrotóxicos seja um dos instrumentos de crítica ao sistema de monocultura extensiva e de tomada de consciência pelo aluno, dos problemas histórico-sociais de seu tempo.

Na sequência, introduz-se a principal controvérsia sociocientífica (QSC) da aula: a contraposição entre o slogan de combustível renovável associado ao biocombustível, amplamente divulgado pela mídia como energia limpa, e, por outro lado, os impactos socioambientais do sistema produtivo de monocultura extensiva desses biocombustíveis, como a cana-de-açúcar e a soja, no Brasil, omitidos pela grande mídia. A introdução dessa tem início com a questão 3 (etapa 3 do item 2. O Problema, apêndice A) na qual os alunos são convidados a pensar e falar o que sabem sobre como os combustíveis renováveis são produzidos em nosso país e quais impactos essa forma de produção pode causar ao meio ambiente.

Os alunos seriam convidados a falar o que sabem sobre a monocultura, sendo que a região da cidade de Ribeirão Preto é envolta por plantações de monocultura extensiva. Seriam convidados a falar sobre a poluição do ar envolvida na produção da cana-de-açúcar e da soja, já que há pouco se falou em emissão de gás carbônico pelo uso do combustível. Em seguida, seriam convidados a falar o que sabem sobre a poluição da água, degradação do solo e impactos na biodiversidade, o que, aos poucos, leva à contraposição entre a ideia de os biocombustíveis serem combustíveis limpos, e à tomada de consciência de que toda degradação ambiental está vinculada ao uso de agrotóxicos necessários ao cultivo de sementes transgênicas, configurando a QSC. 
A necessidade de que o combustível seja fonte de energia limpa deve coincidir com o novo objeto de estudo: o sistema produtivo dos biocombustíveis, e gerar o motivo da ação de reflexão sobre este sistema, o que é feito com a ajuda da mediação do professor:

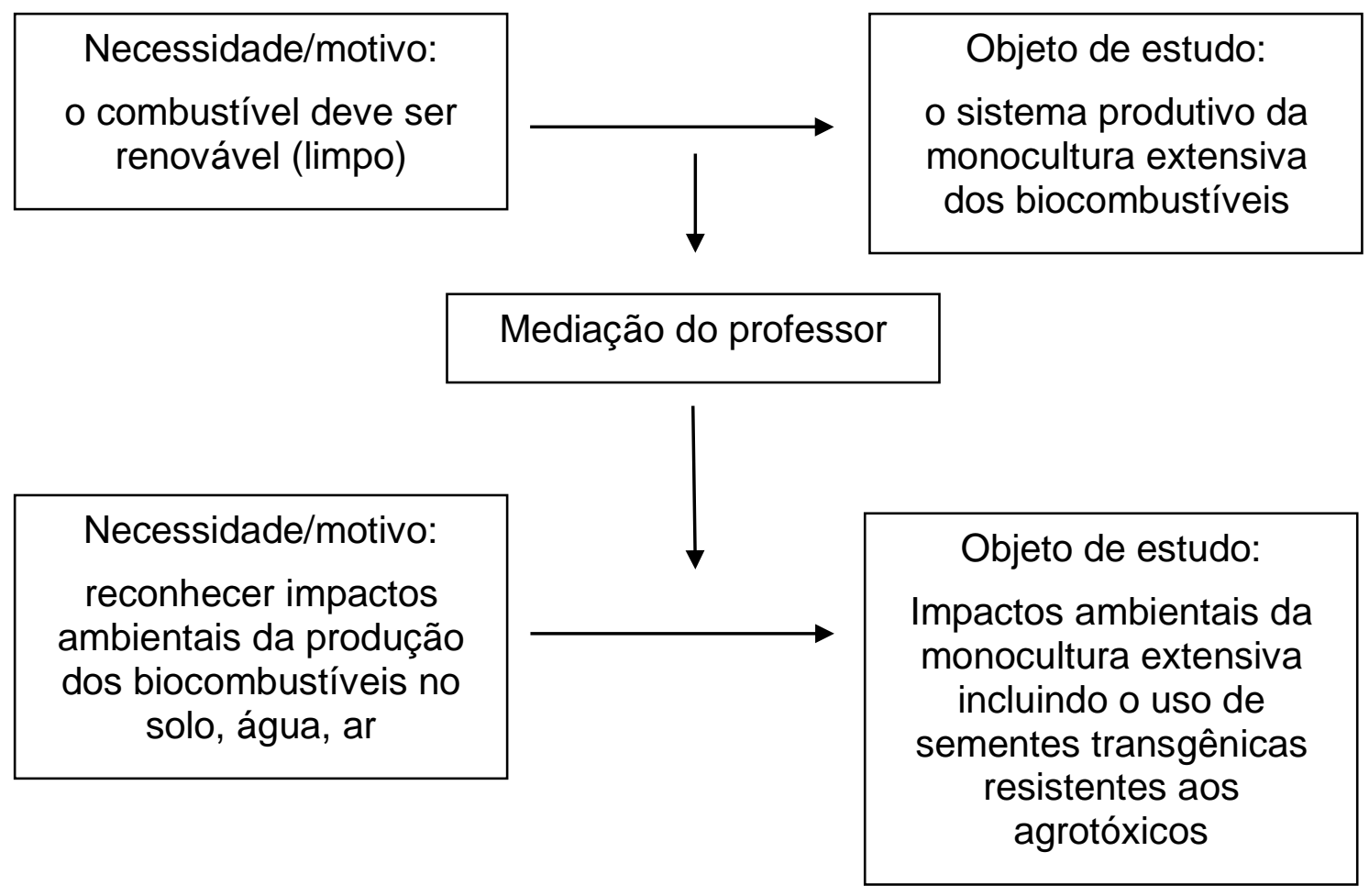

A mediação do professor conduz à análise do sistema produtivo de monocultura extensiva de modo a tornar necessário o levantamento dos impactos ambientais causados por este sistema. A necessidade deste levantamento, colocada pelo professor, coincide com o uso de sementes transgênicas resistentes aos agrotóxicos, gerando o motivo da ação, a qual implica em compreender como funciona, dentro do sistema produtivo, o uso das sementes transgênicas resistentes aos agrotóxicos, já que este é a própria fonte dos impactos ambientais a serem levantados. A intensão é que, compreendendo o funcionamento do uso das sementes transgênicas no contexto histórico-social do aluno, o mesmo tome consciência dos impactos ambientais gerados por este uso e o conceito de biocombustível seja significado, de modo a superar sua aparência. 
O caráter transgênico das sementes está em função de possuir sua base genética modificada com genes resistentes aos agrotóxicos e, assim, serem as únicas espécies a resistirem aos mesmos. Estes, por sua vez, causam danos severos ao meio ambiente, os quais são detalhados por meio do documentário "O veneno está na mesa", que é apresentado para os alunos após a introdução da questão 4, a seguir. Desta forma, o documentário nos serve como instrumento que auxilia na tomada de consciência sobre os impactos ambientais e sociais causados pelo uso de agrotóxicos no sistema de monocultura extensiva, de modo a significar e generalizar os conceitos de combustível limpo, energia limpa, organismos transgênicos, defensivos agrícolas/agrotóxicos, dentre outros.

Focar as questões nas consequências ambientais do sistema produtivo dos biocombustíveis, na terceira etapa, possibilita o levantamento de questões que relacionam diretamente as consequências ambientais a consequências sociais, políticas, econômicas e tecnológicas, sendo todas estas sociais, diretamente relacionadas à produção dos biocombustíveis. Nesse momento, seria introduzida a questão 4 (item 4 do item "O Problema", apêndice A): Estendendo o pensamento sobre a poluição e os impactos ambientais dessa monocultura em larga escala para consequências na vida dos trabalhadores do campo, o que mais podemos identificar de contraditório entre a bandeira/slogan da renovabilidade energética dos biocombustíveis e o modo de produção dos mesmos?

Nesta questão, da mesma forma que anteriormente havia a necessidade de reconhecer os impactos ambientais da produção dos biocombustíveis, agora, a necessidade se estende para o reconhecimento dos impactos sociais gerados pelo sistema produtivo da monocultura extensiva. Esta necessidade, como na etapa anterior, também coincide com o uso de transgênicos resistentes a agrotóxicos (QSC).

A mediação do professor dirige a necessidade de o combustível ser renovável (limpo) para a necessidade de se reconhecer os impactos sociais da produção dos biocombustíveis. A necessidade de o combustível ser limpo deve coincidir com o estudo de sua produção, gerando o motivo das ações deste 
estudo. Estudar o sistema produtivo dos biocombustíveis deve tornar necessário reconhecer seus impactos sociais, o que deve coincidir com o estudo da QSC, gerando o motivo da ação deste estudo, tornando-o uma atividade intencional e consciente de crítica ao sistema produtivo de monocultura extensiva.

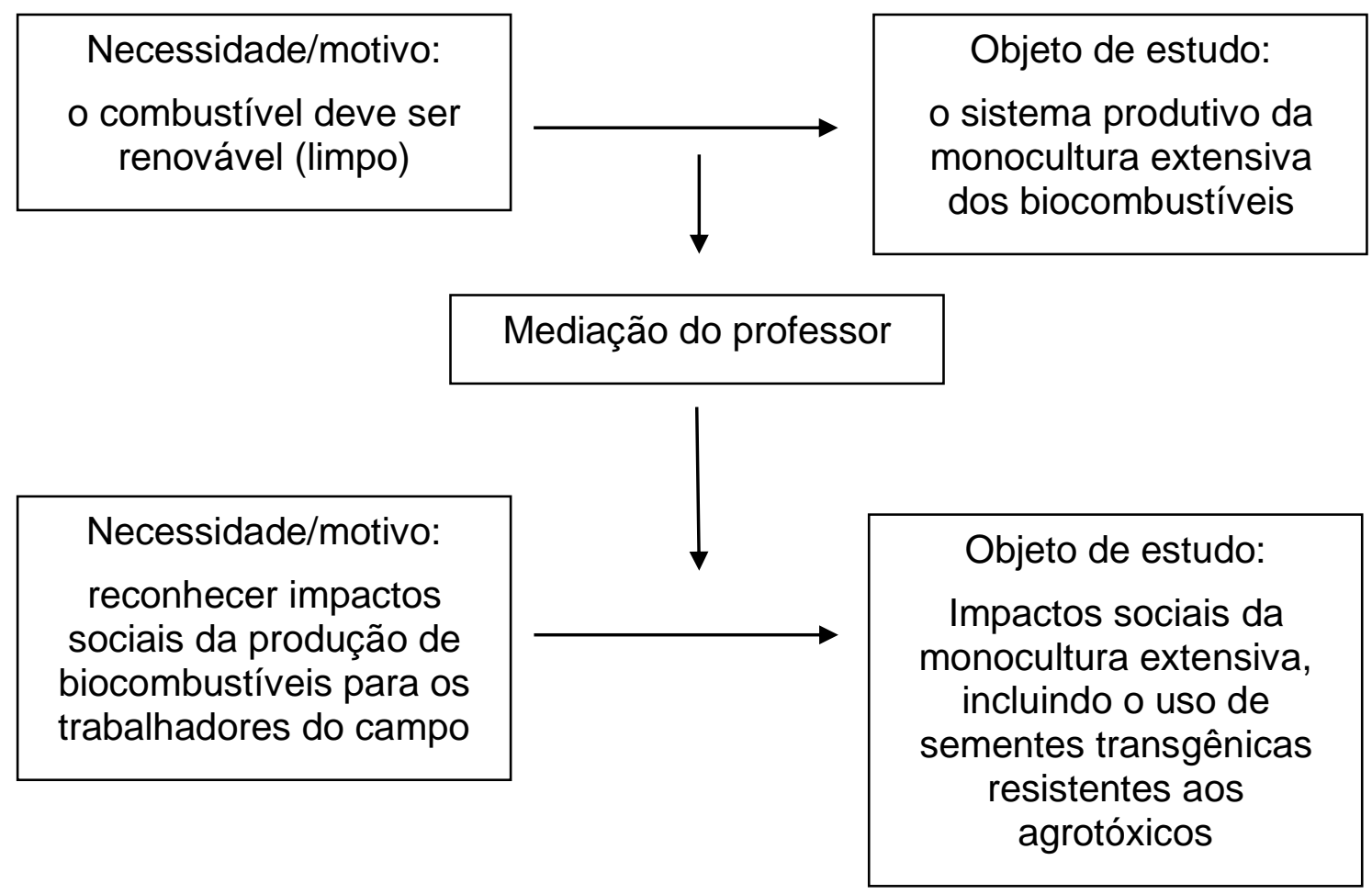

O uso de sementes transgênicas (QSC), neste contexto histórico-social, tem a intensão de trazer a discussão sobre o sistema mercadológico das multinacionais envolvidas, do envolvimento dos órgãos governamentais brasileiros nesse mercado e das consequentes condições com as quais os produtores e trabalhadores rurais se deparam dentro deste sistema, compondo mais relações CTSA relacionadas aos biocombustíveis

Esta etapa da SAt tem início com o levantamento do conhecimento dos alunos sobre este sistema produtivo e tem continuidade com trechos do documentário "O veneno está na mesa", de Silvio Tendler ${ }^{24}$ e colaboradores, a 
fim de ampliar o conhecimento sobre esta QSC no sentido de apresentar fatos históricos da chegada das multinacionais norte americanas que implantaram a chamada "revolução verde", com o apoio do governo, a monocultura extensiva com o uso de transgênicos e "defensivos agrícolas" (agrotóxicos), e as consequências para o meio ambiente, trabalhadores do campo e consumidores finais - os próprios alunos.

Sequência dos trechos do documentário assistido pelos alunos:

1- 2011: Revolução Verde (do início a 10:50 minutos);

2- 2014: Monocultura, transgênicos e agrotóxicos (2:03 a 10:25 min);

3- 2014: Monocultura, transgênicos e agrotóxicos (14:07 a 22:55 min);

4- 2014: Abelhas (dos 53 aos $57 \mathrm{~min}$ );

5- 2011: Kátia Abreu, contaminação do leite materno (17:06 a 23:17min)

6- 2011: Monopólios, explicação do crédito rural (40:00 a 41:53 min);

7- 2014: Agroecologia (28:25 a 42:50 min).

Conforme surgissem comentários ou questões, seriam feitas pausas para discussão.

\subsubsection{Quarta etapa da sequência de atividades}

Após assistirem a trechos do documentário, a questão 5 seria colocada (item 5, item "O Problema", apêndice A): além da produção de biocombustíveis, qual outro setor produtivo é atingido pelos mesmos impactos ambientais e sociais? Quem, além dos trabalhadores rurais, também sofre essas consequências? O que o conceito de entalpia de combustão tem a ver com isso?

Por meio do documentário, que aborda a produção de alimentos em larga escala no Brasil e na América Latina, a discussão sobre o sistema produtivo dos biocombustíveis levantada anteriormente seria unida à questão do sistema produtivo de alimentos. Assim, após assistirem ao documentário, os

https://www.youtube.com/watch?v=fyvoKljtvG4 . Os trechos apresentados para os alunos são uma mescla destas duas versões. 
alunos seriam convidados a relacionar estes sistemas produtivos e a relacionar o conceito de entalpia envolvido na produção e uso dos combustíveis com a produção e consumo dos alimentos que compramos no mercado. Seriam convidados a pensar e falar de que maneira a entalpia está presente nas etapas de produção e consumo dos combustíveis e dos alimentos.

Assim, o professor coloca para os alunos a necessidade de relacionar o conceito de entalpia, visto inicialmente no uso dos combustíveis, com a produção e consumo de alimentos:

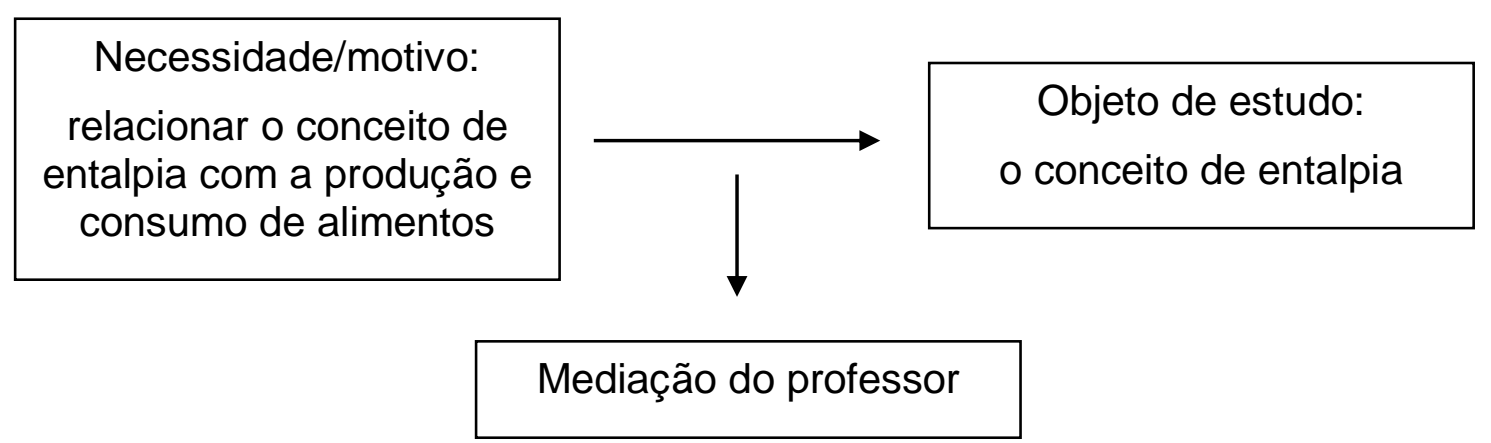

A necessidade ligada ao objeto de estudo deve gerar o motivo da ação, que implica na generalização do conceito de entalpia, do contexto da produção e uso dos combustíveis para o contexto da produção e consumo de alimentos. O que sabemos não ser tarefa fácil para o aluno, devido à complexidade da discussão anterior a essa questão. Dessa forma, a mediação do professor torna-se novamente fundamental e deve continuar a conduzir os alunos na discussão, conforme seja necessário.

O objetivo final dessa reflexão é que os alunos percebam que o balanço energético envolvido nessas etapas, ou seja, a entalpia presente na metabolização dos alimentos e dos combustíveis tem a mesma natureza físicoquímica, e do mesmo modo que um carro precisa do combustível para funcionar, nosso corpo precisa, dentre outros fatores, da energia da respiração celular para funcionar, energia fornecida principalmente pelo metabolismo dos carboidratos presentes nos alimentos. Nesse momento, os alunos seriam convidados a observar a reação de respiração celular da glicose e reconhecêla como uma reação de combustão, com a glicose como outro exemplo de 
combustível, cujo valor energético de metabolização também pode ser calculado.

\subsubsection{Quinta etapa da sequência de atividades}

Em seguida, os alunos seriam convidados a pensar sobre como essa energia que buscamos nos alimentos chega até nós, contaminada com agrotóxicos por meio de um processo bioacumulativo.

Após estas discussões, os alunos seriam convidados a pensar se existe alguma alternativa ao sistema produtivo de monocultura extensiva em questão, por meio da questão 6 (item 6, item "O Problema", apêndice A): como esse cenário da monocultura extensiva poderia ser revertido para um modo sustentável da produção e uso dessas fontes de energia? Existem alternativas para o sistema produtivo da monocultura?

Após a fala dos alunos, seriam apresentados novos trechos do mesmo documentário, cuja ênfase se dá no modo de produção alternativo dos Sistemas de Agro Florestas (SAF) e da Agricultura Familiar, com o objetivo de os alunos tomarem conhecimento sobre estes e sobre as feiras agroecológicas, as barreiras impostas às mesmas e suas possibilidades, lembrando que, sob esse sistema produtivo, o metabolismo energético envolvido na produção e consumo de combustíveis, seja para carros e máquinas, seja para nosso organismo, estaria livre de produtos nocivos à sociedade e ao meio ambiente.

Dentro do contexto social exposto, intenciona-se a necessidade de um sistema alternativo à monocultura extensiva. Esta necessidade é vinculada, pelo professor, por meio dos vídeos, ao Sistema de Agrofloresta, gerando o motivo da ação de compreender este sistema:

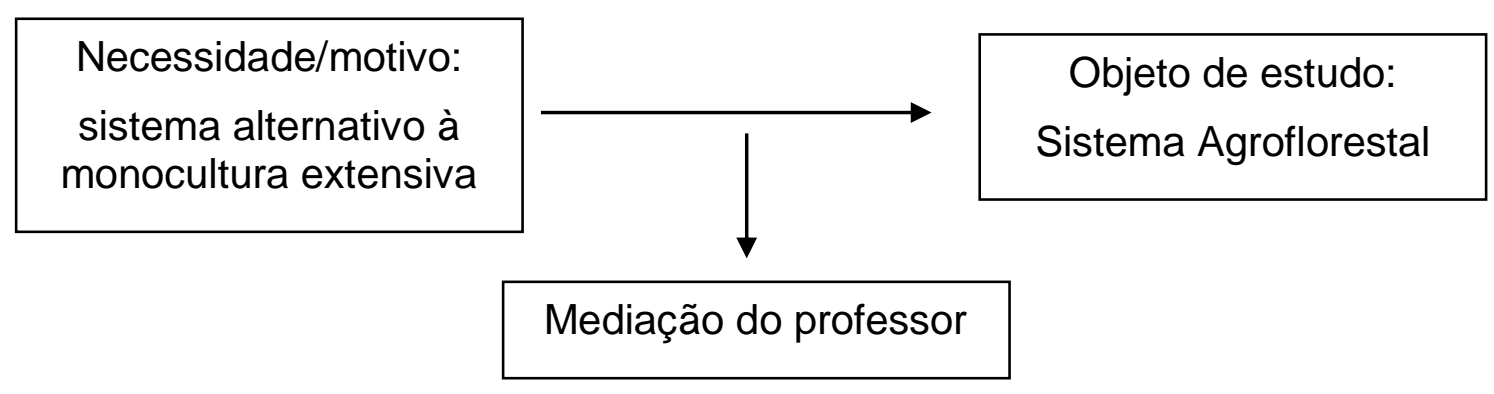


Dessa forma, assistir aos trechos do documentário, os quais focam o funcionamento do Sistema Agroflorestal torna-se uma atividade consciente, motivada pela necessidade de um sistema alternativo àquele que traz consequências drásticas ao meio ambiente e, consequentemente, ao homem, incluindo-se o aluno como sujeito histórico-social deste contexto. Dessa forma, o vídeo, como instrumento de tomada de consciência, modifica a percepção da realidade concreta do aluno.

\subsubsection{Sexta etapa da sequência de atividades}

Como finalização da SAt, os alunos seriam convidados a escreverem sobre a escolha do carro, justificando sua escolha por meio do combustível a ser usado no carro, explicitando as razões da escolha e da eliminação dos combustíveis discutidos.

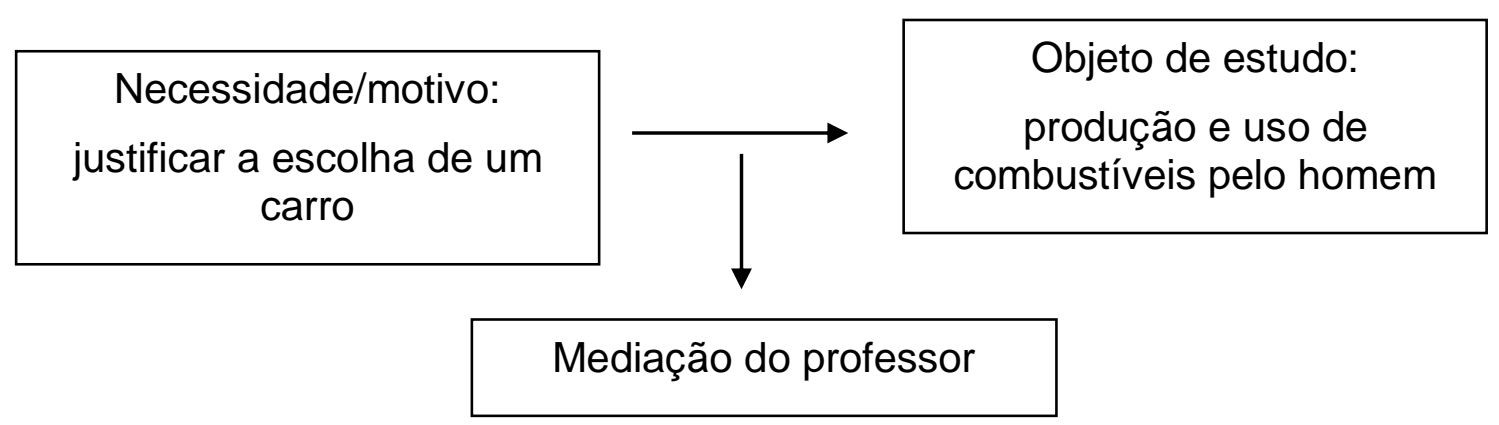

Esta mediação do professor visa à retomada da atividade inicial e síntese da SAt como um todo, bem como à necessidade de justificar a escolha de um carro em função de seu combustível coincidir com o tema discutido em aula, gerando o motivo da ação de análise e posicionamento perante este tema, devendo tornar a escolha de um carro, e seu combustível, uma atividade de reprodução da crítica socioambiental sobre a produção e uso de combustíveis pelo homem.

Obviamente, é esperado que o contexto socioeconômico e a própria limitação das opções de mercado limitem a escolha e justificativa do aluno; no entanto, esperamos que refletir sobre a escolha de um carro ou de um combustível, nesse momento, seja uma ação mais complexa do que era anteriormente a esta sequência de atividades. 
A estrutura da SAt intencionou um movimento que partisse da discussão sobre as principais fontes de energia no Brasil, focalizasse critérios para a escolha de um carro movido a álcool ou gasolina, iniciasse a discussão por meio do critério econômico do combustível, a partir do conceito de entalpia, percorresse questões socioambientais, políticas e tecnológicas e retornasse ao conceito de entalpia no contexto do consumo de alimentos. Tudo isso dentro da questão concernente à escolha do carro que o aluno gostaria de adquirir hipoteticamente.

A abordagem do conceito químico intencionou uma postura que não fosse meramente expositiva por parte dos professores. Ao propor a reflexão sobre a escolha de um carro, os alunos seriam divididos em grupos de seis componentes para que cada dupla calculasse a entalpia de combustão de um dos três combustíveis.

Nesta primeira etapa, em que a questão a ser trabalhada girava em torno da identificação da origem da energia do combustível e da comparação da energia liberada entre os mesmos, o conceito de entalpia seria mediado com os alunos da seguinte forma: estes deveriam primeiro buscar o conceito no livro didático, com a ajuda de seus pares, e, a partir da leitura, solicitar os esclarecimentos de suas dúvidas aos professores. Estes, mediariam os conceitos conforme as necessidades dos alunos. Só após todos os grupos terem realizado os cálculos de entalpia de combustão, a professora pesquisadora prosseguiria com as discussões, as quais seriam feitas entre ela e a classe como um todo.

Entender o processo de liberação de energia pela queima completa dos combustíveis e seu cálculo seria a base para as discussões posteriores sobre qual combustível libera mais energia; a influência do fator energético no rendimento do motor e no preço do combustível; a importância do balanceamento da reação para estas observações e para a observação da quantidade de $\mathrm{CO}_{2(\mathrm{~g})}$ liberada e sua influência na poluição do ar; a reflexão sobre a bandeira midiática da renovabilidade ocultar um modo de produção dos biocombustíveis que implica consequências socioambientais insustentáveis, o que também vale para a produção de alimentos, já que o sistema produtivo é o 
mesmo; a tomada de conhecimento de que existem alternativas sustentáveis para a produção de alimentos e biocombustíveis, SAF e Agricultura Familiar; a percepção de que a necessidade energética no corpo humano, suprida pela alimentação também está envolvida no ciclo do carbono, de modo a reconhecer que uma das principais reações químicas do metabolismo humano, a queima da glicose na respiração celular, é uma reação de combustão e seu valor de entalpia pode ser calculado como nas queimas dos combustíveis estudados inicialmente.

Este movimento de aula foi planejado na tentativa de promover o devido aprofundamento no estudo dos conceitos químicos, em busca de um conhecimento concreto, para que estes não se perdessem de vista nas discussões socioambientais. Esta abordagem foi uma opção consciente de que os aspectos sociais, ambientais, políticos e econômicos presentes nas discussões teriam um caráter informativo reflexivo, no sentido de não serem abordados com a profundidade e amplitude que especialistas nas áreas de ciências humanas e biológicas o poderiam realizar.

A principal fonte de informação sobre o contexto socioambiental foi o documentário "O veneno está na mesa", no qual estes e outros especialistas, bem como trabalhadores do campo, forneciam informações e depoimentos, sendo que, a partir destes, as reflexões eram direcionadas em função da aula pela professora pesquisadora, como já previamente descrito, com a preocupação de aproximar os conceitos químicos da realidade, em busca de um equilíbrio entre estes, de forma a evitar uma abordagem de senso comum em relação à química nas discussões que envolviam aspectos socioambientais e promover o aprofundamento dos conceitos químicos nos níveis macroscópico, representacional e submicroscópico dentro das delimitações planejadas.

Salientamos que a sequência de atividades proposta para a aula é a atividade de escolha de um carro, que, por sua vez, é a atividade de crítica socioambiental da produção e uso dos combustíveis pelo homem. 


\subsection{Procedimentos de análise dos dados}

A análise consistiu em identificar nas interações discursivas e nos textos produzidos pelos alunos os elementos teórico-metodológicos que contribuem para a formação dos conceitos científicos escolares envolvidos, bem como o reconhecimento das condições que promovem as relações entre estes e a realidade concreta (aspectos ambientais, sociais, econômicos e políticos).

As interações discursivas de interesse foram selecionadas em função dos episódios e turnos, dentro da totalidade da sequência de atividades (SAt), que incluem, além das ações e operações dos alunos para a resolução dos problemas, os momentos introdutórios de aproximação do aluno com a SAt.

De acordo com Moura (2000) e Cedro (2008), os episódios permitem a apreensão do fenômeno observado ao desvelarem a qualidade das ações por meio da manifestação dos indivíduos. Assim, estas ações se tornam reveladoras da apropriação do trabalho coletivo, que é o próprio compartilhamento das ações.

Consideramos a construção do conhecimento dos alunos, mais especificamente os indícios de formação de conceitos, o principal fenômeno observado. Observação que se dá por meio das exteriorizações explicitadas nas interações discursivas (aluno-aluno e aluno-professor) em meio às ações compartilhadas na atividade de aprendizagem.

O formato dos episódios, em relação ao modo como começam e ao modo como terminam, foi considerado em correspondência com o formato das ações da atividade "Escolha de um carro", as quais se tornam atividades na medida em que o aluno, motivado, se apropria delas. De acordo com Moura (2000), é na atividade que ocorre o compartilhamento das ações reveladoras das apropriações dos conceitos.

Além das ações da atividade, trouxemos também os episódios anteriores a estas ações, para apresentar como se deu a introdução ao tema "Produção e uso dos combustíveis pelo homem", a aproximação do tema aos alunos, e a introdução da atividade "Escolha de um carro", cujas ações se tornam uma sequência de atividades.

Assim, os episódios selecionados são aqueles que contém a elaboração coletiva das ações que buscam apresentar, aproximar o aluno e buscar 
solucionar ou discutir as situações-problema e situações de tomada de consciência/transformação da percepção da realidade concreta. Os episódios podem ser a própria atividade localizada dentro da sequência de atividades; um diálogo de proposição e apropriação da atividade, um diálogo em que há mudança de percepção em relação a um conceito, ou em relação ao contexto social. Os episódios apresentam uma sequência que busca apresentar a totalidade da atividade, a qual corresponde à totalidade da problemática socioambiental preparada para a mesma.

Nos episódios, estão contidas as unidades de análise, as quais consideramos, assim como Vigotski (2007), como um produto de análise que conserva todas as propriedades da totalidade analisada. Dessa forma, os turnos de fala que contenham as interações entre conceitos científicos e espontâneos, as generalizações, as significações ou apropriações não são analisados isoladamente da totalidade da atividade.

Dessa forma, consideramos a aula e os produtos desta aula como o universo da pesquisa, o conjunto formado pelos episódios de interações discursivas de interesse como o corpus da pesquisa, e as unidades de análise como os turnos das interações discursivas que trazem indícios de formação de conceitos químicos, com foco nos conceitos de entalpia e combustão; o reconhecimento das condições que promovem as relações entre estes e a realidade concreta (aspectos ambientais, sociais, econômicos e políticos).

A análise da formação de conceitos é feita por meio da busca por reconhecimento de elementos teórico-metodológicos da Teoria HistóricoCultural e da Teoria da Atividade, os quais, a partir das considerações sobre os conceitos teóricos focalizados nesta pesquisa, item 3.2. do capítulo de fundamentação teórica, selecionamos com o intuito de nos auxiliar a compreender como se dá o processo de formação de conceitos pelo aluno em função do reconhecimento de indícios da formação de conceitos. Esperamos observar, dentro das limitações temporais da atividade aplicada neste trabalho, indícios que apontam para a formação de conceitos, pois não consideramos esta formação como um estágio pronto e acabado do conceito, mas como um processo em movimento, irredutível aos limites da atividade aqui proposta. 
Dessa forma, pretendemos considerar para a análise das interações discursivas e textos produzidos pelos alunos, reconhecer os seguintes indícios de formação de conceitos:

1. Concretização e sistematização: interação entre conceitos científicos escolares da termoquímica e conceitos espontâneos, os quais consideraremos como colocações de senso comum por parte dos alunos. Como já explicitado no capítulo de fundamentação teórica, tratase da interação na qual os conceitos espontâneos proporcionam concretude aos conceitos científicos e estes proporcionam sistematização aos conceitos espontâneos dentro de um longo e dialético processo de formação de conceitos, mantido pelas relações de generalidade entre conceitos espontâneos e científicos e entre os conceitos científicos (VIGOTSKI, 2009), bem como pelo motivo da atividade (LEONTIEV, 1983);

2. Generalização: relações de generalidade entre conceitos científicos e entre conceitos espontâneos e científicos. Para Vigotski (2009, p. 246 e 292), esta generalização significa tomada de consciência, e, por sua vez, o próprio processo de formação do conceito, sendo o conceito um ato de generalização. A essência do desenvolvimento do conceito é, primeiramente, a transição de uma estrutura de generalização à outra. No início é uma generalização de tipo mais elementar, que, posteriormente, é substituída por generalizações de um tipo cada vez mais elevado. Um conceito científico só será um conceito superior, no aluno se ele estabelecer as relações de generalidade que o sistema conceitual científico determina. $O$ sistema de relações de generalidade são "os vínculos fundamentais mais importantes e mais naturais entre os conceitos" (p. 292). A partir do estudo desta tese e de outros princípios teóricos, Davydov (1988) propõe que o aluno apreenda o princípio geral do conceito por meio de abstrações e generalizações, desde sua manifestação abstrata até sua manifestação concreta, de modo que o aluno perceba como o aspecto geral do conceito também aparece em cada caso particular. Dessa forma, buscaremos identificar generalizações dentro do sistema conceitual científico dos conceitos 
químicos e para além dele, na concretude do contexto histórico-social do aluno. Consideramos que as generalizações que superam o sistema do conceito químico, buscando o vínculo entre ele e o contexto social do aluno contribuam para proporcionar as relações CTSA no processo de desenvolvimento da atividade de estudo pelos alunos.

3. Significação: interação entre sentido pessoal e significado do conceito científico, buscando reconhecer o reflexo dos objetos da realidade concreta na língua e na consciência, unida à objetivação das necessidades (LEONTIEV ,1983). Consideramos que conceitos espontâneos estão próximos ao sentido pessoal que o aluno apresenta inicialmente em relação ao objeto de estudo, assim como os conceitos científicos estão próximos ao significado acumulado historicamente no objeto de estudo, o qual o aluno deve ser motivado a se apropriar, motivado não apenas no sentido de incentivo, mas no sentido de tomar consciência da necessidade daquele conceito dentro da atividade humana historicamente elaborada, presente em seu contexto social. Segundo Leontiev (1983, p. 116), a formação de conceitos é o resultado do processo de apreensão de significações historicamente elaboradas, processo que transcorre dentro da atividade do aluno, em condições de comunicação com as pessoas que o rodeiam. Por trás das significações idiomáticas se escondem as formas de ação (operações) socialmente elaboradas, em cujo processo as pessoas transformam e conhecem a realidade objetiva. As formas de ação analisadas são principalmente as aplicações dos conceitos químicos nas ações que os constituem, como o cálculo da variação de entalpia; a liberação de $\mathrm{CO}_{2(\mathrm{~g})}$ pela reação de combustão; o fenômeno da renovabilidade dos biocombustíveis; as comparações entre os comportamentos químicos do álcool gasolina, e biodiesel; o modo como os combustíveis são produzidos; o modo como as sementes transgênicas e agrotóxicos são empregados; o modo como impactam o meio ambiente, os trabalhadores do campo, os consumidores de alimentos; o modo de funcionamento do sistema agroflorestal; ou seja, as ações práticas e mentais que concretizam os conceitos. Esperamos que estas formas de ação aproximem o aluno do 
significado do conceito, em direção à superação do sentido pessoal. Não a superação que substitui o sentido pessoal pelo significado, mas que agrega conhecimento ao sentido pessoal.

4. Apropriação: reprodução, das formas histórico-sociais da atividade. Assimilação das formas de aplicação dos conceitos na atividade (NÚÑES, 2009). Entendemos que a apropriação, por ser a reprodução das formas da atividade, constituem, em nossa análise, a manifestação dos indícios anteriores nas ações de fala e escrita dos alunos, já que os indícios anteriores necessariamente passam pelo processo de apropriação.

Estes indícios de formação de conceitos estão melhor e mais detalhados no item 3.2. "Conceitos teóricos focalizados na pesquisa".

A busca por esses indícios de formação de conceitos são os principais direcionadores para a escolha dos episódios e turnos de interação discursiva a serem analisados, bem como para a escolha dos textos produzidos pelos alunos a serem analisados, considerando a presença desses indícios nas falas e nos textos, como as expressões que correspondem ao objeto da pesquisa, cuja análise busca responder a questão de pesquisa: como se dá o processo de formação de conceitos da termoquímica em meio a uma atividade de análise socioambiental crítica permeada por aspectos sociocientíficos e questões sociocientíficas (QSC) presentes no contexto social do aluno?

Nossa questão de pesquisa também traz a necessidade de analisarmos as condições que promovem as relações entre os conceitos químicos e 0 contexto social do aluno (aspectos ambientais, sociais, econômicos, políticos). Acreditamos que a análise dessas condições deva estar vinculada à estrutura da atividade proposta (LEONTIEV, 1983), ou seja, de que modo a relação entre as necessidades, motivos, ações e operações proporcionam as relações de generalidade (VIGOTSKI, 2009) entre os conceitos químicos e o contexto social do aluno, considerando que estas relações só são possíveis por meio das relações histórico-sociais nas quais a atividade é construída, ou seja, por meio da mediação do professor e dos próprios alunos entre si, considerando também que a mediação do professor deve ser pensada desde a preparação 
da atividade de aprendizagem, como proposto no item 4.4. do capítulo da metodologia.

Mais especificamente em relação aos textos produzidos pelos alunos, nos quais eles são convidados a justificar a escolha de um carro utilizando elementos do tema discutido em aula, analisaremos a apropriação dos conceitos da termoquímica em meio às relações CTSA, considerando os limites da atividade de produção textual. A apropriação é definida como a reprodução das formas histórico-sociais da atividade de escolha de um carro executada em aula, ou seja, da atividade de crítica socioambiental à produção e ao uso de combustíveis pelo homem, a qual esperamos que reproduza as formas histórico-sociais desses conceitos em meio às relações CTSA, possibilitando reconhecer como os conceitos da termoquímica são apropriados em meio às justificativas e como estas justificativas reproduzem as relações CTSA e as QSC.

Esperamos que, nessa justificativa, nossa busca por uma forma de educação que preza pela superação da ruptura entre a aprendizagem dos conceitos científicos escolares e o contexto histórico-social do aluno seja manifestada de forma que os conceitos científicos estejam relacionados a aspectos sociais, ambientais, econômicos, políticos, tecnológicos, éticos e morais discutidos em aula, utilizando-se, dessa maneira, das relações CTSA e das questões sociocientíficas controversas (QSC).

Assim, a análise da apropriação dos conceitos da termoquímica, em meio às relações CTSA, também nos mostra as formas de apropriação da atividade, a avaliação da atividade pelo aluno (DAVÍDOV e MÁRCOVA, 1987) e a síntese avaliativa da atividade reproduzida em si mesmo, motivado por uma escolha de caráter pessoal e pela própria necessidade de aprendizagem.

Para esta análise, consideramos, conforme a fundamentação teórica utilizada, que a linguagem escrita tem raízes genéticas diferentes da linguagem falada, o que pode ser expresso nas palavras de Vigotski:

A escrita é uma função específica de linguagem, que difere da fala não menos como a linguagem interior difere da linguagem exterior pela estrutura e pelo modo de funcionamento. Como mostra a nossa investigação, a linguagem escrita requer para seu transcurso pelo 
menos um desenvolvimento mínimo de um alto grau de abstração. Trata-se de uma linguagem sem o seu aspecto musical, entonacional, expressivo, em suma, sonoro. [...] uma linguagem abstrata, que não usa palavras, mas representações de palavras. Neste sentido, a linguagem escrita difere da falada da mesma forma que 0 pensamento abstrato difere do pensamento concreto. É natural que, em decorrência disto, a linguagem escrita não possa repetir as etapas de evolução da linguagem falada, não possa corresponder ao nível de desenvolvimento da linguagem falada. (VIGOTSKI, 2009, p. 312 e 313).

Dessa forma reconhecemos que, humanamente, os alunos carregam limitações na linguagem escrita, as quais podem proporcionar inconsistências nas apropriações da atividade, o que também é natural do próprio momento do processo de ensino-aprendizagem, sendo que alguns conceitos podem estar no início de sua formação, outros em estágios mais avançados. Segundo Vigotski (2009), quando uma palavra nova é apreendida pelo sujeito, o seu desenvolvimento está apenas começando. 


\section{Resultados e discussões}

\subsection{Análise das interações discursivas}

Esta análise é apresentada com a intenção de apresentar ou descrever as interações discursivas que permitam compreender a totalidade da atividade proposta no movimento de sua aplicação em sala de aula. Pretendemos mostrar como a colocação dos problemas, a socialização de conceitos, as relações CTSA e as controvérsias presentes nas falas dos professores e dos alunos tomaram forma ao longo do tempo transcorrido na aula, em função dos episódios selecionados para a análise, do relato sobre o andamento da aula e da identificação dos indícios de formação de conceitos. As descrições, os episódios, a análise da formação de conceitos e das relações entre os conceitos da termoquímica com o contexto social do aluno, a partir dos episódios, seguem a sequência temporal da aula, no momento da aplicação, o que pode diferir da sequência planejada no momento da elaboração da sequência de atividades.

Dessa forma, alguns episódios ou descrições não respondem diretamente à questão de pesquisa, como os momentos que antecedem a proposição da atividade de escolha de um carro. No entanto, os consideramos parte da atividade e importantes para que o leitor tenha a noção de como a atividade foi introduzida ao aluno, pois toda a mediação se torna importante para que os objetivos da atividade sejam atingidos. Além disso a aproximação entre o tema da aula e os conceitos químicos aos alunos como sujeitos histórico-sociais que interagem com estes conceitos em seu contexto social compõe a nossa preocupação inicial concernente a ruptura entre os conceitos aprendidos na escola e a vida fora da escola.

Nos episódios em que os alunos interagem com os conceitos científicos da termoquímica que pretendemos analisar - entalpia e combustão organizaremos a análise em função dos conceitos teóricos focalizados para a identificação e discussão de indícios de formação de conceitos - concretização e sistematização; generalização; significação e apropriação, conforme 
estabelecidos nos procedimentos de análise dos dados sob a fundamentação da Teoria Histórico-Cultural.

A partir de agora, apresentaremos as descrições e os episódios, de modo que, após cada episódio, seguirá a análise em função de sua relação direta ou indireta com a questão de pesquisa.

\subsubsection{Introdução da aula e aproximação entre o tema e a realidade} do aluno (episódios 1 e 2)

Primeiramente, a professora propõe que o tema da aula irá girar em torno de combustíveis, perguntando se eles leram o texto introdutório da aula (apêndice A) e, em seguida, pergunta aos alunos o que passa pela cabeça deles quando se fala em matriz energética. Nesse momento, os alunos falam em fontes de energia e hidrelétrica. A professora, com o objetivo de diagnosticar a compreensão dos alunos das palavras "matriz" e "energia", pergunta: "Será que não tem alguma coisa a ver com matriz, que vocês viram na aula de Matemática 1?" Como resposta, uma das alunas sugere a ideia de se organizar o conjunto de várias fontes de energia em uma matriz. Assim, a professora vai até a lousa e pede para que os alunos digam o nome dos tipos de fontes de energia existentes no Brasil e esboça algo parecido com uma matriz de terceira ordem com esses nomes (biomassa, eólica, hídrica, fóssil, dentre outras). Explica que se atribuíssemos valores de potencial energético para cada uma no Brasil, poderíamos fazer cálculos comparativos do potencial disponível ou em uso, renovável e não renovável, dentre outros. Retoma o conceito de matriz energética como o conjunto das fontes de energia de um país. Pergunta quais delas os alunos acham que são as fontes de energia mais usadas no Brasil, e depois diz que, na aula, serão focalizadas a biomassa e a fóssil, principalmente os combustíveis álcool, gasolina e biodiesel, justificando que álcool e gasolina são os mais usados no mercado e o biodiesel por ser apontado na mídia e em pesquisas como combustível promissor.

Aqui é importante salientar que as controvérsias entre biodiesel como combustível limpo versus sua alta liberação de $\mathrm{CO}_{2(\mathrm{~g})}$ e entre combustíveis renováveis versus consequências da monocultura extensiva começam a ser "semeadas" ou induzidas pela professora desde já, pois a ideia do biodiesel 
como combustível promissor é mantida até o momento de introdução das controvérsias, o que também vale para o álcool. Daí a importância da mediação do professor para o estabelecimento de controvérsias.

Depois se segue o seguinte diálogo, no qual a professora solicita que os alunos façam relações, na expectativa de aproximação de sentidos entre 0 tema da aula e a realidade dos alunos.

Os nomes dos alunos são fictícios e os professores são designados por P1 (professora pesquisadora), P2 (graduando em biologia) e P3 (graduando em química). Aluno X significa aluno não identificado.

Episódio 1 Aproximação de sentidos entre combustíveis e o aluno. Primeira tentativa.

\begin{tabular}{|c|c|}
\hline Turno & Interações discursivas \\
\hline 1 & $\begin{array}{l}\text { P1: Eu queria fazer, assim, uma relação entre nós (aponta para todos } \\
\text { da sala), né, porque fala "matriz", fala "combustível", biocombustível, } \\
\text { combustível fóssil, parece que são coisas distantes da gente, né? } \\
\text { Parece que são coisas assim "ah, estão aí, mas eu não tenho nada a } \\
\text { ver com isso". Mas será que é isso mesmo? Será que a gente não tem } \\
\text { relações, inclusive relações diretas com essas fontes de energia? }\end{array}$ \\
\hline 2 & Maria e outra aluna: Sim \\
\hline 3 & P1: Com estes combustíveis? \\
\hline 4 & Maria e Aluna X: Sim \\
\hline 5 & $\begin{array}{l}\text { P1: Quando? (Vivian e Thaís entram na sala mudando cadeiras de } \\
\text { lugar. Todos esperam elas se acomodarem.) }\end{array}$ \\
\hline 6 & $\begin{array}{l}\text { P1: Exemplos, assim, de quando a gente tem contato, né, ou relações } \\
\text { com estes combustíveis, com estas formas de energia? }\end{array}$ \\
\hline 7 & Aluno X: (inaudível) \\
\hline 8 & $\begin{array}{l}\text { P1: Então, mas ó, percebam, vamos focar agora no álcool, gasolina e } \\
\text { biodiesel, beleza? Vamos focar nisso aí. Então, por exemplo, o que } \\
\text { tem a ver o álcool que tá lá no posto...porque assim, "ah, eu não tenho } \\
\text { carro", sei lá, mas o que pode ter a ver com a gente, com a nossa } \\
\text { vida, esses combustíveis aí? }\end{array}$ \\
\hline 9 & $\begin{array}{l}\text { Maria: É que num, no caso do petróleo, por exemplo, ele não é } \\
\text { renovável, então um dia pode acabar }\end{array}$ \\
\hline 10 & P1: Não é renovável? \\
\hline
\end{tabular}




\begin{tabular}{|c|c|}
\hline 11 & $\begin{array}{l}\text { Maria: No caso do etanol, ele é renovável, mas, porém, o impacto } \\
\text { também que ele pode causar...um dia eu posso ter minha fazendinha } \\
\text { e vir um latifundiário roubar minha fazendinha pra plantar cana (risos) } \\
\text { e produzir etanol }\end{array}$ \\
\hline 12 & Franco: A gente (inaudível) ele (risos) \\
\hline 13 & $\begin{array}{l}\text { Maria: Ah, e o biodiesel, ah o biodiesel já é mais limpo, vamos dizer } \\
\text { assim, né, porque já vai poder usar vários...coisos, vários produtos } \\
\text { que poderiam ser descartados...e eles vão reutilizar... eu não sei. }\end{array}$ \\
\hline 14 & $\begin{array}{l}\text { P2: O que quer dizer limpo? O que é esse limpo? Por que "mais } \\
\text { limpo"? }\end{array}$ \\
\hline
\end{tabular}

Percebemos que Maria não estabelece um sentido entre os combustíveis e sua vida pessoal. Quando se refere a sua "fazendinha", trata-se de uma situação hipotética. A principal relação estabelecida é dos combustíveis com o meio ambiente, o que nos mostra que a aproximação entre o tema da aula e o aluno não é algo trivial ou possível sem a mediação da professora, de modo que os conceitos da termoquímica não sejam uma imposição abstrata, ou seja, desligada da realidade histórico-social do aluno. Esta aproximação é fundamental para o envolvimento do aluno com a atividade a ser proposta, o que, por sua vez, é fundamental para que os objetivos da atividade sejam atingidos. Aproximação que não deve ser feita pelo professor, no lugar do aluno, mas pelo aluno, como sujeito da atividade, com a ajuda do professor.

No turno 14, P2 pede a definição do conceito de "limpo", iniciando um episódio com discussão sobre a diferença entre os conceitos "limpo" e "renovável", a qual não chega a um acordo entre os alunos e P2 é interrompida por P1 ao propor que a discussão seja feita no momento de trabalho em grupo. Assim, retoma a pergunta referente à relação entre os combustíveis álcool, gasolina e biodiesel, e os alunos. Destacaremos o episódio em que essas relações são estabelecidas. 
Episódio 2 Aproximação de sentidos entre combustíveis e o aluno. Terceira tentativa.

\begin{tabular}{|c|c|}
\hline Turno & Interações discursivas \\
\hline 65 & $\begin{array}{l}\text { Tamara: Eu acho que a gente facilita nossa vida, porque que, que a } \\
\text { energia dos automóveis, dos aviões, então, facilita nossa vida de } \\
\text { transporte e tudo. Economiza bastante tempo. }\end{array}$ \\
\hline 66 & P2: O Renan anda de bicicleta, o que tem a ver com ele? (risos) \\
\hline 67 & P1: É, pra quem usa carro é fácil, mas e pra quem não usa carro? \\
\hline 68 & P3: Não, ele falou uma coisa interessante aqui, fala, fala aí. \\
\hline 69 & Aluno X: Tá dentro do nosso organismo. \\
\hline 70 & $\begin{array}{l}\text { P1: Não, mas assim, tô falando do álcool, gasolina e biodiesel, a gente } \\
\text { tá nesses três. }\end{array}$ \\
\hline 71 & Aluno X: Eu tô na energia. \\
\hline 72 & P1: Energia desses três. \\
\hline 73 & $\begin{array}{l}\text { Tami: Ah, sei lá, por exemplo: o Renan anda de bicicleta, mas ele } \\
\text { come, e esse alimento, de certa forma, é transportado da lavoura até o } \\
\text { supermercado ou na quitanda com esses combustíveis. }\end{array}$ \\
\hline 74 & ...piadas paralelas \\
\hline 75 & $\begin{array}{l}\text { P1: Boa sacada essa daí, ou seja, mesmo indiretamente tem relação } \\
\text { com a gente }\end{array}$ \\
\hline 76 & Janaína: Tem! \\
\hline 77 & $\begin{array}{l}\text { P1: Né? E o quanto, por exemplo, mesmo que eu não beba álcool, } \\
\text { gasolina ou biodiesel (risos), né, pra chegar alguma coisa até mim, pra } \\
\text { chegar o alimento, pra chegar um produto, tal, teve o transporte, né, e } \\
\text { esse transporte demanda energia, e, meu alimento chegou até o } \\
\text { mercado, eu fui até o mercado e comprei. Então pensa no "macro" } \\
\text { também, nas relações "macro". Pode ser que eu não tenha carro, mas } \\
\text { assim, }\end{array}$ \\
\hline 78 & Tami: Precisa do busão. \\
\hline 79 & Maria: Ainda mais o busão, o diesel do busão pra vim. \\
\hline 80 & P1: Tem o busão... \\
\hline 81 & Maria: É. \\
\hline 82 & $\begin{array}{l}\text { P1: Precisa (concordando com as alunas). E assim, gente, falando em } \\
\text { carro, uma pergunta pessoal, assim, é, todo mundo aqui um dia } \\
\text { gostaria de ter carro? Ou vocês preferem outra coisa? }\end{array}$ \\
\hline 83 & Tami: Olha, eu, eu, eu num... \\
\hline 84 & P1: Assim, gostaria ou pensa em usar carro como meio de transporte? \\
\hline
\end{tabular}




\begin{tabular}{|c|c|}
\hline 85 & $\begin{array}{l}\text { Thainá: Por exemplo, eu..., eu vou fazer dezoito daqui a algumas } \\
\text { semanas, mas aí, tipo, todo mundo pergunta "Ah! E aí, você vai fazer } \\
\text { carta?", não sei quê, mas num, sabe quando cê não faz questão? Eu, } \\
\text { eu não faço muita questão de ter um veículo, por exemplo. }\end{array}$ \\
\hline 86 & $\begin{array}{l}\text { Tami: Ahn, mas, a questão do veículo, Bia, acho que no mundo atual, } \\
\text { se torna uma necessidade, mas acho que atualmente, num, o..., o } \\
\text { veículo, atualmente, de certa forma, tá se tornando uma necessidade! } \\
\text { Porque, por exemplo, eu moro em outra cidade, eu tenho que vim, o } \\
\text { transporte tá caríssimo, hoje em dia compensa mais bancá uma moto } \\
\text { do que, bancá um ônibus diariamente, eu, de ônibus, se eu for, í, voltá, } \\
\text { í, voltá, eu vô gastá mais de seiscentos reais, quase. Então vô consegui } \\
\text { pagá uma moto, qual que é mais viável? E eu tenho que sair bem mais } \\
\text { cedo de casa, dependendo de ônibus e tenho um determinado horário } \\
\text { pra chegar em casa. Então se eu tiver minha moto, eu não vou precisar } \\
\text { de dependê de nada. Então eu vô tê uma maior autonomia, uma maior } \\
\text { liberdade. }\end{array}$ \\
\hline 87 & Tamara: E mais conforto também. \\
\hline 88 & $\begin{array}{l}\text { P1: É interessante essa coisa que, parece que chega um momento da } \\
\text { vida, ou vai chegar, que parece que ter carro vai ser uma necessidade. } \\
\text { Interessante isso. }\end{array}$ \\
\hline 89 & $\begin{array}{l}\text { Janaína: Se você não faz planos de, sei lá, se você pode usar ônibus e } \\
\text { é adepto a uma rotina saudável de andar de bicicleta ou coisa assim, é, } \\
\text { é bom, só que se você não tá disposto a andar de bicicleta, e, pedalar } \\
\text { pra cima e pra baixo, se não quiser ficar dependendo de ônibus, sei lá, } \\
\text { (inaudível) }\end{array}$ \\
\hline 90 & Aluna não identificada: Fora a qualidade do transporte...(inaudível) \\
\hline 91 & $\begin{array}{l}\text { Janaína: Ah, é. Não gente, aqui em Ribeirão melhorou muito o } \\
\text { transporte público. Acho que, eu acho que, quando você pegava o } \\
\text { ônibus azul e o amarelo, depois você pega o (inaudível) }\end{array}$ \\
\hline 92 & Paulo: Éhh...! \\
\hline 93 & $\begin{array}{l}\text { Janaína: nossa, é diferente, pá. Agora assim, sei lá, tipo, se você não } \\
\text { quer depender, se você (inaudível) do seu próprio horário, depende até, } \\
\text { porque se você for fazer seu próprio horário, você depende ainda do } \\
\text { trânsito, sei lá. }\end{array}$ \\
\hline 94 & $\begin{array}{l}\text { Thaís: Ah, eu prefiro andar de ônibus. (outros alunos também falam, ao } \\
\text { mesmo tempo, que preferem andar de ônibus) }\end{array}$ \\
\hline 95 & $\begin{array}{l}\text { Janaína: Eu curto andar de ônibus, porque daí não tem preocupação. Aí } \\
\text { é bom. Só que por exemplo, gastar dezessete reais. }\end{array}$ \\
\hline 96 & P1: Ah, legal também, outros pontos de vista. \\
\hline
\end{tabular}




\begin{tabular}{|c|l|l|}
97 & $\begin{array}{l}\text { Janaína: Eu tô gastando em média trinta e cinco reais por semana só } \\
\text { pra co...(inaudível), sendo que eu moro a cinco minutos daqui, sabe, eu } \\
\text { gasto trinta e cinco reais por semana! Aí num dá né? Eu moro a cinco } \\
\text { minutos daqui. Se eu tivesse uma moto, eu gastaria setenta reais por } \\
\text { mês pra pagá a mensalidade dela, eu tava fazendo as contas, é..., } \\
\text { setenta reais por mês a mensalidade de uma pop, e aí eu coloco quinze } \\
\text { reais, eu encho o tanque e rodo a semana inteira! E aí compensa. Aí eu } \\
\text { vô gastá bem menos por mês. }\end{array}$ \\
\hline 98 & $\begin{array}{l}\text { Vivian: No meu caso também é igual o seu. Eu moro cinco minutos } \\
\text { daqui e gasto, tipo, o mesmo tanto por semana. }\end{array}$ \\
\hline
\end{tabular}

Desde o Episódio 1 e, no Episódio 2, a professora introduz o termo "carro" em meio a suas falas, com o intuito de direcionar a discussão rumo à proposta da atividade de reflexão crítica sobre a escolha de um carro.

Nos turnos 69 a 72, o aluno não identificado se adianta ao citar a energia envolvida entre o nosso organismo e a energia dos combustíveis. Infelizmente, a mediação da professora acabou por interrompê-lo, a fim de preservar a linha de raciocínio planejada para aula, cuja proposta previa esta discussão quando o conceito de entalpia fosse vinculado à energia nos alimentos. Com exceção desses turnos, até o turno 78 as alunas priorizaram relações impessoais com os combustíveis e os meios de transporte, de uma maneira mais relacionada à sociedade em geral, sem se incluir.

Já a partir do turno 79 , as relações passam a ser pessoais, com os meios de transporte que utilizam diariamente, com foco inicial ao transporte público. Em 81 e 84, P1 tenta direcionar essa discussão para o uso pessoal de um carro. Inicialmente, a realidade de alguns alunos prevalece sustentando o transporte público, posteriormente, a moto. No turno 86, Tami coloca a questão de ter um veículo como uma necessidade, exemplificando o seu caso, o que corrobora com o objetivo da professora em estabelecer o motivo inicial da sequência de atividades, em levar os alunos a pensarem a escolha de um carro para si, como se segue no episódio 3. No episódio 2, os alunos reconhecem sua relação cotidiana com os combustíveis a serem discutidos, o que contribui para a aproximação entre sentido pessoal e os combustíveis como um dos objetos de estudo dentro da atividade. 


\subsubsection{Proposição da atividade ou sequência de atividades da aula:} pensar sobre a escolha de um carro sob vários pontos de vista (episódio 3).

No episódio 3, nota-se que, assim que $\mathrm{P} 1$ propõe a escolha de um carro no turno 104, já aparece o fator econômico como critério para a escolha, em 105 e em 118 em diante, o que corrobora para tornar o fator econômico uma necessidade. Em contrapartida, os critérios de Paulo não incluem economia, mas reforçam o sentido pessoal de sua escolha, observando-se, também, que os alunos demonstram estar motivados e envolvidos na proposta. Em 117, a professora tenta induzir os alunos a optar por um carro 1.0, já que a tabela com os rendimentos dos motores a álcool e gasolina que os alunos irão utilizar se refere a um motor 1.0 .

Episódio 3 Proposição da atividade ou sequência de atividades da aula: pensar sobre a escolha de um carro sob vários pontos de vista.

\begin{tabular}{|c|l|}
\hline Turno & Interações discursivas \\
\hline 100 & $\begin{array}{l}\text { P1: É, pra se pensar. (concordando com as alunas). Então gente, eu } \\
\text { pensei nessa questão, do carro..., depois que vocêtiver, sei lá, moto, } \\
\text { se vai ter carro ou não... Eu pensei em a gente pensar nisso. Na } \\
\text { escolha do carro. Se a gente fosse aqui, pensar hoje, que todo } \\
\text { mundo vai comprar um carro, vamo dize assim, né. Por exemplo, no } \\
\text { que que vocês pensariam? Vamo agora fechar pra carro, a gente } \\
\text { fechou pra álcool, gasolina e biodiesel, agora vamo fechá, pra gente } \\
\text { começar pensar na escolha de um carro. Tá? Éh..., que..., quais os } \\
\text { critérios vocês iriam usar? }\end{array}$ \\
\hline 101 & Tamara: Conforto (conversas paralelas sobre critérios) \\
\hline 102 & Janaína: Pra usá ou não usá? \\
\hline 103 & $\begin{array}{l}\text { P1: ah, mas vamo colocá um limite, assim, algum valor? Um valor } \\
\text { assim de, sei lá... }\end{array}$ \\
\hline 104 & Janaína: o carro que der pra pagar e que fizer menos com um litro. \\
\hline 105 & Tamara: É. \\
\hline 106 & P1: Vamo dize assim que..., vamo colocá um valor de trinta mil \\
\hline 107 & Tamara: trinta mil? \\
\hline 108 & $\begin{array}{l}\text { P1: trinta mil. Não dá nem pra comprar um carrão, mas também não } \\
\text { dá pra }\end{array}$ \\
\hline 109 & Janaína: ah, não, tem carro que compra a menos de dez \\
\hline
\end{tabular}




\begin{tabular}{|c|c|}
\hline 110 & $\begin{array}{l}\text { P1: vamo pensá nesse valor..., é..., legal, se vocês quiserem pensar, } \\
\text { assim, por exemplo, cada um pensar num valor, é legal. Eu tava } \\
\text { pensando em trinta mil. }\end{array}$ \\
\hline 111 & Paulo: êhh, se compra um carro da hora, hein!? \\
\hline 112 & P1: e, sei lá, de comprar um zero, ou um seminovo, num sei. \\
\hline 113 & Paulo: Eu iria de Maveric quadrado à turbo!... \\
\hline 114 & Vários alunos: Nooossaaa, vixx...(risos) \\
\hline 115 & Janaína: se roda meio quilômetro já foi um tanque! (risos) \\
\hline 116 & $\begin{array}{l}\text { Paulo: não, é só pa desfilá no sabadão... (muitos risos e } \\
\text { comentários) }\end{array}$ \\
\hline 117 & $\begin{array}{l}\text { P1: é, então, aí já começou os critérios que vocês iam usar: beleza, } \\
\text { modelo, cor,... }\end{array}$ \\
\hline 118 & Thaís e outras: economia. (comentários paralelos) \\
\hline 119 & $\begin{array}{l}\text { P1: economia? Então, então vocês, todo mundo ia pegar um ponto } \\
\text { zero? }\end{array}$ \\
\hline 120 & Paulo: eu não! (risos) \\
\hline 121 & $\begin{array}{l}\text { Tami: Depende, um ponto zero naquela subida do Morro do São } \\
\text { Bento não ia aguentar! }\end{array}$ \\
\hline 122 & P1: Mas assim, sei lá, com trinta mil dá pra pegar..., um 1.8 \\
\hline 123 & Vivian: Não, gasta muito! \\
\hline 124 & P1: 1.6? \\
\hline 125 & Vivan: 1.6 ainda gasta \\
\hline 126 & P1: 1.4? \\
\hline 127 & Vivian: 1.0 \\
\hline
\end{tabular}

Neste momento, P1 não explica todos os pontos de vista pelos quais a escolha do carro será pensada. Inicia a primeira ação da atividade no próximo episódio, aproveitando a deixa da aluna sobre o critério econômico, um dos critérios que já era esperado para ser discutido. Na verdade, trata-se de um critério que pertence ao senso comum da maioria dos consumidores, constituindo-se como um elemento do contexto histórico-social do aluno.

A importância deste episódio reside na proposição da atividade de escolha de um carro por meio da mediação de P1, a assimilação da atividade pelos alunos e a passagem do motivo da atividade de escolha de um carro para a ação de levantamento de critérios, dentre os quais o fator econômico 
torna-se a nova necessidade. Esta deverá ser vinculada ao tipo de combustível utilizado e gerar o motivo da ação de investigação do problema "qual dos combustíveis compensa mais, economicamente?" O que só possível pela mediação da professora.

A assimilação da atividade, de acordo com Davídov e Márcova (1987), é valorada no processo da formação da atividade de maneira a discordar de que o processo de assimilação seja contraposto ao processo de desenvolvimento psíquico, sendo a assimilação do motivo, ações e operações um passo fundamental para o desenvolvimento da mesma. Também é fundamental para o processo de organização, ensino e comunicação da experiência socialmente elaborada, sendo a atividade de estudo uma experiência socialmente elaborada entre alunos e entre aluno e professor, sendo a formação e o desenvolvimento da atividade um processo que traz transformações tanto para os alunos quanto para os professores. Desta forma, se a formação dos conceitos ocorre em atividade, a assimilação da atividade é passo fundamental nesta direção.

Em seguida, a professora pede para que os alunos se dividam em três grupos compostos por seis integrantes, e tem um pouco de dificuldade na mediação das primeiras questões, pois alguns alunos demoram a se organizar em grupo.

\subsubsection{Primeira etapa da sequência de atividades (episódio 4)}

No turno 136, quando P1 diz: "vocês sabem isso", diz isso porque como essa sequência de atividades é a segunda aplicação, o conceito teórico de entalpia já tinha sido exposto para os alunos na aplicação piloto, como consta no início do capítulo metodológico. Ou seja, eles já tiveram um primeiro contato com os conceitos de calor, entalpia, entalpia padrão de formação, combustão, entalpia de combustão, reações endotérmicas e exotérmicas. Inclusive, as tabelas citadas pela professora, nos turnos 140 e 144 são as mesmas da aplicação piloto. Reconhecemos que P1 se expressou mal, pois deveria ter dito que aos alunos que eles já viram isso em aula anterior. 
A Teoria Histórico-Cultural nos dá base para entender que um primeiro contato com esses conceitos não seria suficiente para seu desenvolvimento a ponto de os alunos "saberem" sobre eles e terem se apropriado, sendo apenas o início do desenvolvimento desses conceitos (VIGOTSKI, 2009, p. 246). Desse modo, a aula atual seria uma tentativa de dar continuidade ao desenvolvimento dos conceitos, propondo uma aplicação para os mesmos.

Episódio 4 Introdução da $1^{\underline{a}}$ ação da atividade (apêndice $A$, item 2. $O$ Problema, etapa 1)

\begin{tabular}{|c|c|}
\hline Turno & Interações discursivas \\
\hline 134 & $\begin{array}{l}\text { P1: Beleza, pessoal? Na página } 14 \text { vai começar as questões, as } \\
\text { questãs, como diz o Tio B, as questãs pra gente discutir, né, sobre } \\
\text { esses três combustíveis. É..., então, pessoal, nesse primeiro item, a } \\
\text { gente vai começar pensar sobre o valor energético do combustível, né, } \\
\text { pra gente começar pansar, né, o que tudo envolve o combustível e a } \\
\text { escolha do nosso carro. Primeira coisa, ó: se eu for pensar da onde } \\
\text { que vem. Ah! Não precisa responder agora pra mim assim, tá. Cada } \\
\text { questão, cada item desse aqui, vocês vão primeiro chegar num } \\
\text { consenso no grupo, tá, e depois a gente vai socializar. }\end{array}$ \\
\hline 135 & $\begin{array}{l}\text { (algo não identificado por meio do vídeo atrapalhou o andamento da } \\
\text { aula. Algo relacionado a mudança de lugar de alunos e P3) }\end{array}$ \\
\hline 136 & $\begin{array}{l}\text { P1: Gente, ó, fala sério agora, vai. A primeira questão que o grupo vai } \\
\text { pensar é: de onde vem o desempenho energético do combustível, - } \\
\text { vocês sabem isso - como que eu posso calculá-lo - vocês sabem isso. }\end{array}$ \\
\hline 137 & Janaína: Nossa, num sei não! (risos) \\
\hline 139 & $\begin{array}{l}\text { Vivian: essas pessoas de humanas. Essas pessoas de humanas. (faz } \\
\text { piada com colega) }\end{array}$ \\
\hline 140 & $\begin{array}{l}\text { P1: É..., uma dica pra vocês, é que, atrás aqui, no final da aula, } \\
\text { (inaudível) tem as tabelas para ajudarem vocês, tá? Então de onde } \\
\text { vem, né, o desempenho energético, como que eu posso calcular,... Aí } \\
\text { começa outra questão: entre álcool e gasolina, qual que é mais } \\
\text { compensador economicamente. }\end{array}$ \\
\hline 141 & Paulo: ah, hoje em dia no Brasil.. \\
\hline 142 & Alunas X: sssssssssssss (pedem silêncio) \\
\hline 143 & P1: Ó, guarda,...guarda para o grupo. \\
\hline
\end{tabular}


P1: Aí, o que que vai acontecer, é..., essa formação de grupos com bastante pessoas no grupo tem um propósito, tá. Isso quer dizer que vocês vão se dividir, dentro do grupo, em álcool, gasolina, e biodiesel. Pra facilitar o trabalho, pra vocês não terem que calcular de todos, fazer três vezes cada um. Aí, por exemplo, vocês decidem: a dupla tal vai ficar com o álcool, a outra gasolina, a outra biodiesel. E, quando vocês calcularem, vocês têm que comparar, não tem? Precisa comparar quem libera mais energia, pra ver qual que compensa mais, né? Aqui atrás tem tabela de rendimento do motor. Vocês podem ver qual que rende mais, aí pra ver essa (inaudível) econômica, o que que vai pesar no bolso, né, quando a gente for escolher o carro. Então, vamo fazer isso daí então, discutir essa primeira?

No episódio 4, a mediação da professora em colocar a primeira situação-problema está mais atrelada ao material didático e à organização dos grupos do que à discussão do problema. Apenas coloca, no turno 144, "Precisa comparar quem libera mais energia, pra ver qual que compensa mais, né?", indicando a necessidade de quantificar a energia liberada pelo combustível, o que tem a intenção de gerar o motivo da ação do cálculo de entalpia, por meio da necessidade do cálculo para a comparação entre as energias liberadas pelos combustíveis, transformando-o em atividade. A mediação das ações e operações do cálculo, que gera novas ações e operações ocorre no atendimento aos grupos, exemplificado no episódio a seguir.

A partir desse momento, os alunos começam a trabalhar em grupo, se apropriar das ações da atividade e dos conceitos químicos, por meio da sua necessidade dentro da atividade e da ajuda dos seus pares e professores. Os professores percorrem os grupos conforme os alunos os solicitam, pedindo ajuda. O momento de atendimento aos grupos são os momentos de maior interação aluno-aluno e alunos-professor, em torno da apropriação de conceitos por meio de ações. 
5.1.4 Reconhecimento da tarefa e socialização dos conceitos de entalpia, reação de combustão (episódio 5)

O episódio 5 mostra como um dos grupos se apropria da atividade de cálculo de entalpia, inicialmente entre si, e, posteriormente, com a ajuda da professora. Desde o início, a apropriação se dá na relação com o outro.

Episódio 5 Reconhecimento da tarefa e socialização dos conceitos de entalpia, reação de combustão. Grupo: May, Thaís, Jessi, Breno, Alisson, Samanta.

\begin{tabular}{|c|l|}
\hline Turno & Interações discursivas \\
\hline 147 & Samanta: tem que calcular o valor energético, num é? \\
\hline 148 & $\begin{array}{l}\text { May: Oh, Breno, Breno, a gente tem que calcular a entalpia da reação, } \\
\text { não? }\end{array}$ \\
\hline 149 & Thaís: eu acho que tem que calcular. \\
\hline 150 & Jessi: eu acho. \\
\hline 151 & May: porque aqui tem a de formação, né? A gente tem que calcular... \\
\hline 152 & (começam a ler o texto da introdução da aula) \\
\hline 153 & $\begin{array}{l}\text { Jessi: eu acho que eu vô pegá um livro lá, perguntar pro livro. Onde que } \\
\text { tem livro de química? }\end{array}$ \\
\hline 154 & P1: E aí, gente, vocês resolveram fazer o quê? \\
\hline 155 & Thaís: a gente já sabe o que fazer (referindo-se a sua dupla com a May) \\
\hline 156 & P1: Han? Que ótimo! \\
\hline 157 & $\begin{array}{l}\text { Breno: Só que a gente não sabe por onde começar. Tem que fazer } \\
\text { aquelas contas? (inaudível) entalpia? }\end{array}$ \\
\hline 158 & $\begin{array}{l}\text { P1: de onde vem o desempenho do combustível? De onde será que vem, } \\
\text { pensando, sei lá, pega um, da gasolina }\end{array}$ \\
\hline 159 & Samanta: Da combustão. \\
\hline 160 & P1: Da combustão. Por quê? \\
\hline 161 & Breno: Vai liberar energia. \\
\hline 162 & $\begin{array}{l}\text { P1: Vai liberar energia. Isso. E a gente pode calcular, não pode? Essa } \\
\text { energia? }\end{array}$ \\
\hline 163 & Alunos concordam com a cabeça \\
\hline 164 & P1: Que é a? \\
\hline 165 & Aluna(o) X: Entalpia \\
\hline 166 & P1: Entalpia. E pra calcular a entalpia, o que eu tenho que fazer? \\
\hline
\end{tabular}




\begin{tabular}{|c|c|}
\hline 167 & Aluna X: (inaudível) \\
\hline 168 & P1: É, então, entalpia é o quê? O que seria a entalpia? \\
\hline 169 & Aluno X: O calor liberado \\
\hline 170 & $\begin{array}{l}\text { P1: O calor liberado (volta ao grupo que estava para pegar o gravador, e } \\
\text { retorna com o mesmo) }\end{array}$ \\
\hline 171 & P1: Então tá, então a entalpia é? A entalpia é? Cê falô, cê acabou de falá! \\
\hline 172 & Breno: É a liberação de calor do,... do material? \\
\hline 173 & $\begin{array}{l}\text { P1: Isso, é o calor que o combustível libera, né, e eu posso calcular. } \\
\text { Como? (sem resposta). Vocês tavam aqui na aula do Hugo? }\end{array}$ \\
\hline 174 & Alisson: Sim \\
\hline 175 & P1: Ele falou um pouco disso \\
\hline 176 & $\begin{array}{l}\text { Alisson: Eu só sei que eu só lembro algumas coisa, que tem é, a entalpia } \\
\text { negativa é quando o material perde calor, né? A positiva é quando recebe. }\end{array}$ \\
\hline 177 & P1: Isso, quando recebe. Então a combustão é o quê? \\
\hline 178 & Alisson: Perda de calor \\
\hline 179 & P1: É perda, é perda, liberação, né? \\
\hline 180 & Alisson: Liberação de (inaudível). Ou seja, é negativa \\
\hline 181 & P1: É, alguém tem alguma sugestão de como calcular? \\
\hline 182 & May: (risos) Final menos inicial? \\
\hline 183 & P1: Final o quê? Menos inicial o quê? \\
\hline 184 & May: Energia final menos a inicial \\
\hline 185 & Alisson: Temperatura? \\
\hline 186 & $\begin{array}{l}\text { P1: Energia final menos energia inicial? E a partir do quê, assim, que eu } \\
\text { vou ter essas energias finais e iniciais? A Jessi sabe. }\end{array}$ \\
\hline 187 & Alisson: Tem que pegar a reação. Pegar, faze o negócio da combustão \\
\hline 188 & P1: Da reação, que reação? \\
\hline 189 & Alisson: Reação química lá, que vai ter \\
\hline 190 & P1: Reação de combustão \\
\hline 191 & Alisson: É hehehe \\
\hline 192 & P1: Isso. E como que é a reação de combustão? \\
\hline 193 & Jessi: É aquilo que, tipo, se tiver troca, num sei as palavras certas \\
\hline 194 & $\begin{array}{l}\text { P1: É até antes disso. É antes disso que eu tô, que a gente tá falando. } \\
\text { Como que seria a reação de combustão desse combustível? Qual que cê } \\
\text { vai, ceis já acertaram quem vai fazer qual? Álcool, gasolina... }\end{array}$ \\
\hline 195 & Breno: Gasolina, álcool, depois a gente faz junto o biodiesel \\
\hline 196 & de combustão da \\
\hline
\end{tabular}




\begin{tabular}{|c|c|}
\hline & mbustível..., hã? \\
\hline 197 & May: Oi? (risos) O oxigênio é um comburente. \\
\hline 198 & P1: E o que que vai acontecer com os dois? \\
\hline 199 & May: Tem que ter uma energia de liga, de... Ignição, de ativação \\
\hline 200 & Alisson: Ignição que no caso é a (inaudível) \\
\hline 201 & 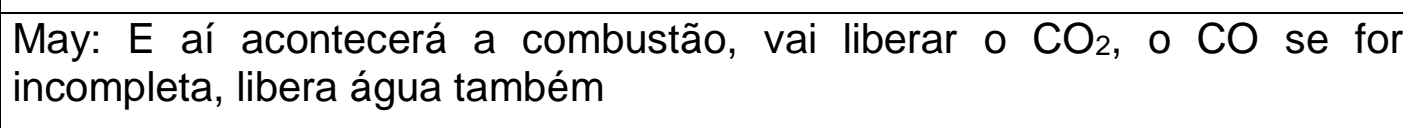 \\
\hline 202 & $\begin{array}{l}\text { P1: Isso. Então é isso, a partir dessa reação que a gente vai escrever ela e } \\
\text { vai calcular. Então o combustível, você a gasolina. Escolhe o octano, que } \\
\text { eu acho que a galera tá escolhendo o octano. Então vocês podem até } \\
\text { começar a montar a reação. Como que é a fórmula do octano? }\end{array}$ \\
\hline 203 & Alisson: $\mathrm{C} 8 \mathrm{H} 18$ ? \\
\hline 204 & $\begin{array}{l}\text { P1: C } 8 \text { H 18. Então cê pode começar a montar a reação aí. Cê vai fazer } \\
\text { qual? O álcool? Qual que é a fórmula do álcool? É, faz o etanol. }\end{array}$ \\
\hline 205 & $\begin{array}{l}\text { Alisson: O negócio eu entendi no dia, agora eu olho e tá parecendo que tá } \\
\text { alemão. }\end{array}$ \\
\hline 206 & Thaís: $\mathrm{C} 2 \mathrm{H} 5 \mathrm{OH}$ \\
\hline 207 & $\begin{array}{l}\text { P1: Então você pode começar a colocar, } \mathrm{C} 2 \mathrm{H} 5 \mathrm{OH} \text {...Isso, aí então o } \\
\text { combustível vai reagir com? }\end{array}$ \\
\hline 208 & Alisson: O comburente \\
\hline 209 & P1: O comburente que é o oxigênio do ar \\
\hline 210 & Thaís: Então coloca mais? (sinal de adição da reação) Mais o O? \\
\hline 211 & $\begin{array}{l}\text { P1: Mais O2. Porque, por exemplo, o álcool sozinho, ele não reage } \\
\text { sozinho, né? Senão a gente não poderia comprar álcool e ter álcool em } \\
\text { casa (risos). Então, mas se você der uma ignição, riscar um fósforo e, e } \\
\text { colocar no álcool...Então precisa ter o oxigênio, o combustível que cada } \\
\text { um tá calculando, e uma faísca. Aí eles vão reagir. Pra indicar que reagiu a } \\
\text { gente coloca? }\end{array}$ \\
\hline 212 & Alisson: Igual \\
\hline 213 & P1: Setinha. \\
\hline 214 & Alisson: Setinha. \\
\hline 215 & $\begin{array}{l}\text { P1: E o produto da combustão? Vocês lembram? Combustão completa, } \\
\text { né? Vai ser sempre } \mathrm{CO}_{2} \text { e água, da combustão completa. Peraí que eu já } \\
\text { volto. }\end{array}$ \\
\hline
\end{tabular}

No episódio 5, observamos que os alunos, para identificarem a primeira ação a ser realizada, utilizaram como instrumentos o próprio material, livros 
didáticos e as interações com os colegas. Até o turno 155, demonstraram conseguir identificar que a primeira ação a ser feita era o cálculo de entalpia, mas não sabiam como e quais instrumentos deveriam utilizar para dar início à objetivação da ação, segundo a fala de Breno, em 157. Nesse momento, já empregam o uso do termo entalpia, mas não sua funcionalidade. Ao pedirem ajuda, P1 volta à pergunta inicial da questão "De onde vem o desempenho do combustível?", tomando como instrumento a gasolina, e fazendo a mediação do conceito de entalpia nos limites do sistema de relações de generalidade da reação de combustão, mediando relações entre os conceitos de calor, energia liberada, entalpia, reação de combustão, comburente, combustível, álcool, gasolina, biodiesel e suas fórmulas moleculares, bem como as do dióxido de carbono, oxigênio e água. Vale salientar que a reação de combustão não estava dada no material, ou seja, foi preciso que os alunos as sistematizassem com a ajuda da professora.

A partir de agora, organizaremos a análise em função dos conceitos teóricos focalizados para a identificação e discussão de indícios de formação de conceitos, já que, neste episódio, tem início a interação dos alunos com os conceitos da termoquímica.

\subsubsection{Análise em função dos conceitos teóricos focalizados para a} identificação e discussão de indícios de formação de conceitos

\subsubsection{Sistematização e concretização (episódio 5: Reconhecimento da tarefa e socialização dos conceitos de entalpia, reação de combustão)}

O episódio 5 é a primeira redução do concreto ao abstrato (CAMILO e MATTOS, 2014) na sequência de atividades. O concreto considerado como realidade objetal social refletida na linguagem, mediada pelo material didático preparado para o aluno (apêndice A), pelas falas expressas por alunos e professores até este momento, repletas de aspectos presentes no cotidiano dos alunos. Realidade agora relacionada ao uso dos combustíveis pelos alunos e a necessidade de saber qual dos combustíveis compensa mais economicamente. Os conceitos espontâneos utilizados dentro desta realidade serão considerados neste e nos demais episódios como conceitos de senso comum, com os quais os alunos já operam espontaneamente em seu 
cotidiano. Neste episódio, em função da análise, observamos que os conceitos espontâneos são representados pelas palavras gasolina, álcool, biodiesel, calor e combustível. O abstrato, neste episódio, é considerado como o sistema de relações de generalidade determinado pelo sistema conceitual científico (VIGOTSKI, 2009, p. 292) dos conceitos de entalpia com sua forma geral (DAVIDOV, 1988) de cálculo ${ }^{25}$, e de combustão com sua forma geral de reação ${ }^{26}$, com os quais os alunos não operam sem a ajuda da professora, mesmo tendo assistido a uma aula expositiva sobre os conceitos de combustão e entalpia na aplicação da sequência didática piloto, mesmo lembrando de algumas características destes conceitos (turno: T. 176).

Gostaríamos de salientar aqui uma consideração a fim de explicitar nossas considerações sobre os conceitos espontâneos. Para isso, tomaremos o exemplo do termo "calor".

O calor, dentro de seu sistema conceitual científico refere-se principalmente à transferência de energia térmica de um sistema para outro ou dentro do mesmo sistema. Já no cotidiano, o mesmo termo é associado à característica "quente" de um material ou ambiente, que por sua vez é associada à temperatura, como ocorre aqui, em T. 185. Assim, no cotidiano, como conceito espontâneo, o calor não se encontra sistematizado em meio ao seu sistema conceitual científico, ao seu significado científico. Para o adolescente, ainda é um pseudoconceito ou conceito transitório (VIGOTSKI, 2009) operado no senso comum. É esta a forma como consideramos o calor um conceito espontâneo, o que vale para os demais conceitos espontâneos analisados daqui em diante.

A partir destas considerações, observamos ser a professora quem busca contribuir com a concretização dos conceitos científicos a partir dos espontâneos. As falas dos alunos permanecem no abstrato, provavelmente porque é justamente o entendimento do abstrato a necessidade do aluno

\footnotetext{
${ }^{25}$ Considerada como o balanço energético da reação química, obtido pela diferença entre a energia do estado final e a energia do estado inicial da reação química à pressão constante.

${ }^{26}$ Consiste na interação entre combustível, comburente e energia de ignição, resultando em dióxido de carbono e água (para combustíveis compostos por hidrogênio), como componentes fundamentais.
} 
dentro da atividade, o que a configura como atividade de aprendizagem. Segundo Davídov e Márcova (1987) e Rubtsov (1996), a atividade de aprendizagem passa por uma atividade concreta, porém só é atividade de aprendizagem se os processos de aquisição do conteúdo forem o objetivo direto e se o problema proposto é resolvido pela atividade. Por outro lado, a preocupação (motivação) da professora, vinculada à necessidade de sua atividade de ensino (MOURA e MORETTI, 2011), em criar vínculos entre conteúdo e realidade, proporciona o uso de conceitos espontâneos (cotidianos) para contribuir com a concretização dos abstratos.

Observemos os seguintes turnos:

158 - "De onde vem o desempenho do combustível? De onde será que vem, pensando, sei lá, pega um, da gasolina”.

173 - “Isso, é a, o calor que o combustível libera...”.

194 - “...Como seria a reação de combustão desse combustível? Qual que cê vai, ceis já acertaram quem vai fazer qual? Álcool, gasolina”.

196 - “Tá, a gasolina, né, é... Como que é a reação, então, de combustão da gasolina? Gasolina é o combustível..., hã?"

204 - “...cê vai fazer qual, o álcool? Qual é a fórmula do álcool? É, faz o etanol"

211 - “...Porque, por exemplo, o álcool sozinho, ele não reage sozinho, né? Senão a gente não poderia comprar álcool e ter álcool em casa...mas se você der uma ignição, riscar um fósforo e, e colocar no álcool...Então precisa ter o oxigênio, o combustível...e uma faísca..."

Estes turnos usam principalmente os termos combustível, gasolina, calor, álcool, riscar um fósforo, faísca como termos mais familiares aos alunos para interagirem com os conceitos de energia, entalpia, ignição, combustão, comburente. Os primeiros, considerados aqui como espontâneos, estão mais próximos à linguagem cotidiana do aluno e, por isso, proporcionam concretização para os segundos. Dentro do mesmo movimento, os segundos 
contribuem para sistematização dos primeiros (VIGOTSKI, 2009, cap. 6). Este complemento entre concretização e sistematização pode ser confirmado ao longo do episódio, pois os alunos conseguem acompanhar e se apropriar da mediação da professora, respondendo-a de modo a relacionar os conceitos científicos aos espontâneos. Vejamos alguns turnos de respostas dos alunos aos turnos anteriores:

159 - Samanta: da combustão (resposta a 158)

197 - May: ... O oxigênio é um comburente (resposta a 196)

206 - Thaís: $\mathrm{C}_{2} \mathrm{H}_{5} \mathrm{OH}$ (resposta a 204)

As perguntas que utilizam os conceitos espontâneos trazem respostas nas quais os alunos utilizam conceitos químicos, os quais, em meio a este processo, tem sua sistematização iniciada (entalpia e reação de combustão), contribuindo também para a sistematização dos conceitos espontâneos.

Os conceitos de álcool ou gasolina, por exemplo, como no caso do conceito de calor, no cotidiano, são utilizados fora do sistema conceitual científico, no entanto, no movimento da atividade, começam a ser relacionados com sua nomenclatura oficial, com sua fórmula molecular, como um dos componentes fundamentais da reação de combustão, o que os sistematizam e também sistematizam os conceitos de combustível e reação de combustão. Assim como o conceito de calor contribui para a concretização do conceito de entalpia e este para a sistematização do conceito de calor, a concretização contribui para que a sistematização esteja vinculada ao concreto e não seja puramente abstrata.

Este episódio nos mostra também, que mesmo sendo um movimento em direção ao abstrato, o qual parte da verificação de um fator econômico dos combustíveis rumo ao cálculo de entalpia, a mediação da professora busca constantemente apoio nos termos cotidianos para o desenvolvimento da ação da atividade, tendo-os como instrumentos de ensino-aprendizagem, fazendo do movimento do concreto ao abstrato um movimento de idas e vindas em direção ao abstrato. 


\subsubsection{Generalizações (episódio 5: Reconhecimento da tarefa e socialização dos conceitos de entalpia, reação de combustão)}

Pretendemos identificar generalizações internas e externas ao sistema conceitual científico dos conceitos termoquímicos. As internas são determinadas pelo sistema de relações de generalidade, que contém os vínculos fundamentais mais importantes e mais naturais entre os conceitos (VIGOTSKI, 2009, p. 292), o que, para Davídov (1988), se desenvolve na forma genética geral ou lei universal do conceito. As generalizações externas são aqui consideradas as relações de generalidade que partem do sistema conceitual dos conceitos químicos (abstratos) e se vinculam com o contexto histórico-social do aluno, ou mesmo fazem o caminho inverso.

No episódio 5, destacamos os turnos 192 a 202 como um exemplo do desenvolvimento da forma genética geral, ou lei universal do conceito de combustão para este grupo de alunos, em conjunto com a professora, que evoca a necessidade dos elementos fundamentais da combustão por meio de perguntas respondidas pelos alunos. Esse movimento de perguntas e respostas promove os vínculos fundamentais entre conceitos, determinado pelo sistema conceitual científico do conceito de combustão, constituindo sua forma genética geral. Esta estrutura de generalização deve ser transferida para a estrutura do sistema conceitual da variação de entalpia, por meio de generalizações, pois, de acordo com Vigotski (2009, p. 246), a essência do desenvolvimento do conceito é, primeiramente, a transição de uma estrutura de generalização a outra. Dessa forma, o desenvolvimento do conceito de entalpia alavanca o desenvolvimento do conceito de combustão.

Como já dito no capítulo da metodologia, o conceito de reação de combustão e seu balanceamento já havia sido abordado em aulas anteriores, mas é interessante notar que, aplicar este conceito em um novo contexto, que serve como instrumento para o cálculo de entalpia, exige um movimento de generalização para o sistema conceitual de cálculo de entalpia que os alunos não conseguem fazer sem a ajuda da professora. Vemos que, nesses turnos, a aluna May, apesar de saber responder às perguntas da professora, ou seja, apesar de ter reproduzido os conceitos fundamentais da reação de combustão, ainda precisava estabelecer as relações de generalidade entre a reação de 
combustão e o cálculo de entalpia, o que nesta aula, para uns alunos foi mediado pelos professores e para outros alunos foi mediado pelo livro didático de química. Ou seja, a necessidade de uma nova generalização requer mediação.

O episódio 5 se inicia com a necessidade do cálculo de entalpia, mas serve para reconhecer a necessidade do uso da reação de combustão para o cálculo, finalizando com a estruturação da reação de combustão pelos alunos. O cálculo, em si, não foi registrado por nossos áudios e vídeos, mas seu vínculo e sua generalização inicial com a combustão estão expressos entre os turnos 181 a 190, mais especificamente nos turnos 184, 186 e 187, nos quais é expresso que a variação entre a energia final e inicial é obtida a partir da reação de combustão.

Quanto às generalizações externas, consideramos, primeiramente, 0 sistema de relações de generalidade do conceito científico, determinado pelo sistema conceitual científico; em segundo lugar, que o conceito científico proporciona sistematização ao conceito espontâneo. Logo, podemos considerar que esta sistematização é uma relação de generalidade de dentro para fora do sistema conceitual científico, ou seja, dos nexos internos para os nexos externos.

Em terceiro lugar, consideramos que o conceito espontâneo, no adolescente e no adulto, possui um certo grau de sistematização. Se considerarmos que o conceito espontâneo proporciona concretude ao conceito científico, depreende-se que o conceito espontâneo proporciona concretude à sistematização dos conceitos científicos, o que nos leva à conclusão de que os conceitos espontâneos ajudam a sistematizar os conceitos científicos desde que a concretude sirva de base ao abstrato.

Dessa forma, quando a professora se utiliza dos conceitos álcool, gasolina, biodiesel, combustível, desde o cotidiano do aluno, para dar base concreta ao entendimento dos conceitos de combustão e entalpia, está proporcionando relações de generalidade para além do sistema conceitual científico, proporcionando sistematização tanto dos conceitos espontâneos quanto dos próprios conceitos científicos. 
Apesar de só aparecer na questão colocada, consideramos a relação do fator econômico do combustível com a variação de entalpia da reação de combustão uma relação de generalidade entre ciência (conceitos da termoquímica), tecnologia (combustível, carro) e sociedade (fator socioeconômico do gasto gerado pelo combustível).

\subsubsection{Significações (episódio 5: Reconhecimento da tarefa e socialização dos conceitos de entalpia, reação de combustão)}

Consideradas, aqui, como reflexo das características, nexos e relações da experiência humana (conceito), reduzida ao contexto idiomático. Aproximação ao significado do conceito com transformação do sentido. Por trás das significações idiomáticas se escondem as formas de ação, em cujo processo as pessoas transformam e conhecem a realidade objetiva (LEONTIEV, 1983).

Consideramos, primeiramente, as manifestações dos alunos que, dentro da totalidade a atividade de estudo, coadunam com o significado dos conceitos abordados, o que acontece nos turnos 165, 169, 172, 176, 178, 180, 182, 184, $187,197,199,200,201,203,206,208$. Estes turnos são resposta dos alunos que trazem características, nexos e relações coincidentes ao significado dos conceitos da termoquímica.

Percebemos que, realmente, como diz Leontiev, por trás das significações estão as formas de ação, o que não implica apenas 0 funcionamento do conceito no plano material, mas no plano ideal. Todos os conceitos referidos implicam em pensar na ação no mundo ou com o mundo, como: 169 "calor liberado"; 172 "liberação de calor"; 173 "Perda de calor"; 176 "...a entalpia negativa é quando o material perde calor...a positiva é quando recebe"; 184 "Energia final menos inicial"; "Tem que pegar a reação, faze o negócio da combustão"; 201 "E aí acontecerá a combustão, vai liberar o $\mathrm{CO}_{2(\mathrm{~g})}$, o CO se for incompleta, libera água também".

Dessa forma, acreditamos que, se percebermos o movimento, as ações que guardam dos conceitos que ensinamos, entenderemos que o mesmo só existe, só se faz conceito na realidade concreta, em meio a ação que objetiva 
atender a uma necessidade humana, em meio a atividade. O que são as perguntas da professora, senão necessidades do conceito? Da ação do conceito. Do efeito do conceito na realidade objetiva?

As significações dos conceitos, consideradas como as reproduções, em si mesmo, das formas, capacidades histórico-sociais, da atividade. (DAVÍDOV, 1988), já são por si mesmas a reprodução de formas de atividade, desde que o conceito esteja vinculado à sua ação construída histórico-socialmente e a ação em função de uma necessidade humana. Mas até o momento falamos destas manifestações na forma idealizada da linguagem oral.

As reproduções das formas histórico-sociais da atividade devem incluir outras formas de representações, como a linguagem escrita e simbólica, as quais começam a ser reproduzidas pelos alunos a partir do turno 203, quando dão início à organização escrita da reação de combustão e passam a operar com símbolos químicos e números.

\subsubsection{Apropriações (episódio 5: Reconhecimento da tarefa e socialização dos conceitos de entalpia, reação de combustão)}

Como também entendemos que a apropriação e a assimilação não incidem apenas sobre o conceito, mas perpassam todos os elementos da atividade humana, desde o motivo até a objetivação, bem como as formas de como as atividades se inter-relacionam, acreditamos que as reproduções anteriores não teriam ocorrido da maneira como ocorreram se os alunos não tivessem se apropriado do motivo, da situação-problema e das necessidades (DAVÍDOV e MÁRCOVA, 1987).

Aqui, destacamos a importância da apropriação de uma ação que constitui o conceito de entalpia e seu sistema de relações de generalidade partindo-se de um problema que reside, ao mesmo tempo, na atividade de estudo e no contexto histórico-social dos alunos, promovendo a unidade entre a realidade objetiva e atividade do sujeito (LEONTIEV, 1983), contribuindo para a relação CTS entre os conceitos químicos e o contexto social econômico dos alunos. E ao mesmo tempo a apropriação do cálculo de entalpia desencadeia 
novas ações e operações (LEONTIEV, 2012) que inter-relacionam os conceitos do sistema de relações de generalidade (VIGOTSKI, 2009).

A passagem do motivo da atividade de escolha de um carro para a ação de levantamento de critérios gera a necessidade da economia, que, por sua vez, se transformará na atividade de verificação sobre qual combustível é mais barato, que por sua vez, gera a necessidade de comparação das energias liberadas pelos combustíveis, que por sua vez, gera a necessidade do cálculo de entalpia, o qual, gera a necessidade da reação de combustão, o que, de acordo com nosso entendimento sobre Leontiev (2012, p. 69) compõem um processo de surgimento de novas atividades e de novas relações com a realidade.

Após organizarem e escreverem a reação de combustão, as alunas teriam que balanceá-la para, depois, calcularem a entalpia de combustão a partir dos valores tabelados da entalpia padrão de formação das substâncias envolvidas nas reações.

\subsubsection{Sistematização no nível das operações com conceitos (episódio 6: balanceamento da reação de combustão do octano)}

O episódio 6 mostra, em uma dupla de alunas, o momento em que a ação de organização da reação de combustão requer o balanceamento da reação, o que leva as alunas ao nível das operações de soma, multiplicação e divisão, configurando o balanceamento da reação de combustão como uma ação dentro da atividade de cálculo de entalpia.

Episódio 6 Balanceamento da reação de combustão do octano por Maria, Tamara e P2. (Reação: $\mathrm{C}_{8} \mathrm{H}_{18(\mathrm{~g})}+12,5 \mathrm{O}_{2(\mathrm{~g})} \rightarrow 8 \mathrm{CO}_{2(\mathrm{~g})}+9 \mathrm{H}_{2} \mathrm{O}_{(\mathrm{g})}$ )

\begin{tabular}{|c|l|}
\hline Turno & Interações discursivas \\
\hline 30 & Maria: Aí, aqui eu vô tê qui,...balancear, né? \\
\hline 31 & P1: Balancear. \\
\hline 32 & Maria: Aqui tem 8 \\
\hline 33 & Tamara: Põe um 8 aqui \\
\hline 34 & Maria: Começo pelo... \\
\hline
\end{tabular}




\begin{tabular}{|c|l|}
\hline 35 & $\begin{array}{l}\text { Tamara: Começa com o carbono mesmo. Deixa o oxigênio por último } \\
\text { porque ele tá sozinho. Põe o 8 aí na frente, aí vai ficar 8, 16. }\end{array}$ \\
\hline 36 & $\begin{array}{l}\text { Maria: Peraí, não, peraí. Hidrogênio eu tenho 18, e aqui eu tenho 2, } \\
\text { então eu preciso de 9. }\end{array}$ \\
\hline 37 & Tamara: Não, aqui é duas vezes 8. \\
\hline 38 & Maria: Aqui eu tenho 18. Mais 9?...E, 16, mais 9? \\
\hline 39 & P2: Mas por que mais 9? \\
\hline 40 & Tamara: Por que você pois esse 9 aí na frente? \\
\hline 41 & Maria: (inaudível) \\
\hline 42 & Tamara: Não, deixa o oxigênio por último \\
\hline 43 & Maria: Eu sei, mas eu tô contando o hidrogênio. Entendeu? \\
\hline 44 & Tamara: Eu contaria... \\
\hline 45 & $\begin{array}{l}\text { Maria: O hidrogênio, tem 18, aqui eu tenho 2, então eu, preciso, de 9, } \\
\text { entendeu? Então, é..., 16 mais 9? 16. 17, 18, 19, 20, 21, 22, 23, 24, } \\
\text { 25. 25... }\end{array}$ \\
\hline 46 & Tamara: Eu num tô entendendo o que cê tá fazendo \\
\hline 47 & P2: la dar 12,5 \\
\hline 48 & $\begin{array}{l}\text { Maria: 12,5. Aqui vai ficar 12,5. Assim? Aí ficaria balanceado. Mas se } \\
\text { a gente...mesmo assim se a gente...vai ficá assim mesmo. }\end{array}$ \\
\hline
\end{tabular}

O nível das operações se caracteriza pela operação com habilidades que não precisam ser apropriadas pelo sujeito em meio a ação, pois se configuram como conhecimento já internalizado. As operações cumprem o objetivo de uma ação, mas este objetivo não coincide com o motivo da atividade. (LEONTIEV, 1983).

\subsubsection{Concretização e sistematização (episódio 7: Perguntas sobre o cálculo da variação de entalpia)}

No episódio 7 não houve uso de conceitos espontâneos para proporcionar concretude aos conceitos científicos. A sistematização é baseada na relação entre variação de entalpia, entalpia padrão de formação, reagentes e produtos da reação, reação de combustão, coeficientes estequiométricos e as relações quantitativas entre eles, ou seja, a sistematização ocorre dentro do sistema conceitual científico do cálculo da variação de entalpia. 
Podemos perceber no turno 264 que o aluno estava operando com a entalpia padrão de formação como um dos instrumentos para o cálculo da entalpia de combustão.

Episódio 7 Perguntas sobre o cálculo da variação de entalpia por Max e P1.

\begin{tabular}{|c|c|}
\hline Turno & Interações discursivas \\
\hline 252 & $\begin{array}{l}\text { Max: Aqui, no caso, é o que deu. Aí eu tem que pegar o que deu e } \\
\text { subtrair dessa? Que é, a inicial aqui? }\end{array}$ \\
\hline 253 & $\begin{array}{l}\text { P1: Não, aqui, aqui já é o resultado final porque aqui você já fez } \\
\text { final menos inicial, né? }\end{array}$ \\
\hline 254 & Max: Não, ainda não. Ainda tem que pegar a final, menos a inicial. \\
\hline 255 & $\begin{array}{l}\text { P1: É, você tem assim, cê vai pegar a energia, a entalpia padrão } \\
\text { do } \mathrm{CO}_{2}\end{array}$ \\
\hline 256 & Max: Ahan. \\
\hline 257 & P1: Mais a entalpia padrão da água \\
\hline 258 & Max: Que é isso daqui \\
\hline 259 & $\begin{array}{l}\text { P1: E vai somar. Cê vai pegar a entalpia padrão desse e somar } \\
\text { com a entalpia padrão desse }\end{array}$ \\
\hline 260 & Max: E subtrair dessa \\
\hline 261 & $\begin{array}{l}\text { P1: Aí o final, o que que é? O produto, né? O que deu depois. A } \\
\text { entalpia que você somou aqui, menos a entalpia inicial }\end{array}$ \\
\hline 262 & Max: Entendi. \\
\hline 263 & P1: Aí esse é o resultado, essa energia que liberou. \\
\hline 264 & $\begin{array}{l}\text { Max: Só que, como a de oxigênio é zero, então é só pegar a } \\
\text { daqui, né? A do oxigênio é zero, ó }\end{array}$ \\
\hline 265 & P1: É, é zero. \\
\hline 266 & Max: Entendi. \\
\hline 267 & Pietro: Podi crê. \\
\hline
\end{tabular}

\subsubsection{Apropriação e generalização (episódio 7: Perguntas sobre o cálculo da variação de entalpia)}

O episódio 7 registra parte do processo de apropriação da atividade do cálculo de entalpia para Max. O cálculo da variação da entalpia foi mediado por meio dos valores de entalpia padrão de formação dos reagentes e produtos 
(tabela 1, apêndice A), que tiveram o papel de instrumentos para esta atividade.

As falas de Max reproduzem para professora, para si mesmo e para Pietro, sua dupla, as formas historicamente elaboradas da atividade de cálculo da variação de entalpia de combustão. A reprodução destas formas proporciona relações de generalidade entre conceitos científicos determinadas pelo sistema conceitual científico do conceito de variação de entalpia. Estas formas contêm o princípio geral do conceito de variação de entalpia, baseado na ação de variação entre a somatória dos valores de energia dos produtos (energia final) subtraídos da somatória dos valores de energia dos reagentes (energia inicial). Entendemos, a partir de Davídov (1988) que a reprodução deste princípio geral poderá ser percebida pelos alunos em casos particulares que vierem a aplicá-lo, os quais se utilizam de outros instrumentos para a mediação da mesma forma geral de ação do conceito de entalpia no lugar dos valores de entalpia padrão de formação utilizados neste momento, como o cálculo de variação de entalpia por meio dos valores de energia de ligação química ou por meio de gráficos de energia (eixo y) versus desenvolvimento da reação (eixo x). Estes outros instrumentos foram aplicados em aulas posteriores a esta, não analisadas no presente trabalho.

\subsubsection{Significação (episódio 7: Perguntas sobre o cálculo da variação de entalpia)}

Ao contrário do episódio 5 , no qual as significações expressas pelos alunos ocultavam as formas de ação dos conceitos, no episódio 7, a significação do conceito de variação de entalpia é a significação da própria forma de ação do conceito, em cujo processo, segundo Leontiev (1983), as pessoas conhecem e transformam sua realidade objetiva. O que se seguirá nos próximos episódios com o movimento de retorno ao concreto, retorno ao critério econômico da escolha de um carro sob a verificação do preço dos combustíveis.

Tanto o cálculo de variação de entalpia como a reação de combustão e seu balanceamento são conceitos que servirão de instrumentos para que os alunos possam comparar os valores de entalpia de cada combustível e, a partir 
dessa comparação, partir para as próximas ações: a comparação entre os rendimentos dos motores e preço dos combustíveis, em um movimento do abstrato ao concreto, em direção à verificação de qual combustível compensa mais economicamente, observado no episódio 8.

Episódio 8 Relações entre os fatores energético e econômico no posicionamento da escolha entre álcool e gasolina.

\begin{tabular}{|l|l|}
\hline Turno & Interações discursivas \\
\hline 207 & Gabriela: Deu 4470 KJ/mol \\
\hline 208 & Rafael: A entalpia. \\
\hline 209 & Gabriela: A entalpia. \\
\hline 210 & P1: Do quê? Da gasolina? \\
\hline 211 & Gabriela: É. \\
\hline 212 & $\begin{array}{l}\text { Rafael: E no caso aqui do meu, do álcool, deu menos 1236. Aí pra } \\
\text { responder que é..., qual dos dois compensa mais é, quando libera } \\
\text { mais, é mais? É melhor? Quando libera menos é melhor? Como é que }\end{array}$ \\
\hline 213 & $\begin{array}{l}\text { P1: Então, a gente pode... O que que vai fazer?... Qual compensa } \\
\text { mais a gente pensa no carro, né? Que a gente tá pensando em } \\
\text { escolher um carro. É..., o que que vai fazer eu optar por álcool ou } \\
\text { gasolina? }\end{array}$ \\
\hline 214 & Rafael: Qual roda mais... \\
\hline 215 & Gabriela: ...por quilômetro e qual é mais barato. \\
\hline 216 & P1: E isso... \\
\hline 217 & Rafael: Pra compensar mais tem que liberar mais calor. \\
\hline 218 & $\begin{array}{l}\text { Gabriela: Não, não é nem tanto em questão de entalpia, é questão de } \\
\text { lógica também. }\end{array}$ \\
\hline 219 & $\begin{array}{l}\text { P1: É, libera, questão de liberar mais calor, e uma outra questão } \\
\text { também que vocês falaram, de rodar. O quanto que roda? Qual é o } \\
\text { rendimento do motor? }\end{array}$ \\
\hline 220 & Gabriela: Tem na tabelinha, lá trás. \\
\hline 221 & P1: É, tem na tabelinha o rendimento do motor. É lá na página 17. \\
\hline 222 & $\begin{array}{l}\text { Gabriela: A gasolina, na cidade, ela faz 13,5 quilômetros por litro, e o } \\
\text { álcool, 9,2 quilômetros por litro. Então rende mais. }\end{array}$ \\
\hline 223 & P1: Então, e a gasolina libera mais energia? \\
\hline 224 & Rafael: Vê aí. \\
\hline Gabriela: Quanto libera o álcool, do seu \\
\hline
\end{tabular}




\begin{tabular}{|c|c|}
\hline 226 & Rafael: menos 1236 \\
\hline 227 & Gabriela: O meu deu $4470 \mathrm{KJ} / \mathrm{mol}$ \\
\hline 228 & P1: É, menos 4470 \\
\hline 229 & Rafael: Ah, então libera mais. \\
\hline 230 & P1: Então a gasolina...? \\
\hline 231 & Gabriela: Libera mais energia. \\
\hline 232 & P1: Libera mais energia, e? \\
\hline 233 & Rafael: Roda mais. \\
\hline 234 & Gabriela: Roda mais. \\
\hline 235 & P1: Será que tem alguma relação? \\
\hline 236 & Rafael: Então, isso que eu ia (alunos pensam durante 6 segundos) \\
\hline 237 & $\begin{array}{l}\text { Gabriela: Não fica coisado na minha cabeça o que que é esse "liberar } \\
\text { energia", sabe, num, num consigo... }\end{array}$ \\
\hline 238 & $\begin{array}{l}\text { P1: Liberar energia: é..., a reação de combustão, ela não é, tipo uma } \\
\text { explosão? }\end{array}$ \\
\hline 239 & Gabriela: É. \\
\hline 240 & P1: Né, e, por exemplo, o motor do carro, como... \\
\hline 241 & $\begin{array}{l}\text { Max: É, vai ficar mais fácil, acho que, tipo, o motor do carro, não é } \\
\text { nem tanto, tipo, queimar, jogar energia fora, é transformar energia, } \\
\text { que ele tá pegando essa energia, transformando em outro tipo de } \\
\text { energia, que é o movimento. Então, tipo, quanto mais energia ele tá áto } \\
\text { liberando, mais ele tá transformando em movimento, e mais o carro } \\
\text { anda. }\end{array}$ \\
\hline 242 & Gabriela: Ah, entendi, agora sim. \\
\hline 244 & Gabriela: Mas também tem que ver o preço, se é mais barato. \\
\hline 245 & Rafael: O álcool é bem mais barato. \\
\hline 246 & $\begin{array}{l}\text { P1: Então, mas olha só, olha só, concentra de novo no que vocês } \\
\text { tavam vendo: a gasolina libera mais energia, e? Rende mais. }\end{array}$ \\
\hline 247 & Rafael: Rende mais, só que é mais caro. \\
\hline 248 & P1: Qual que é... \\
\hline 249 & Gabriela: Huummm! \\
\hline 250 & P1: Tem alguma relação aí. \\
\hline 268 & $\begin{array}{l}\text { Gabriela: Bia! A gasolina, ela é mais cara que o álcool, isso faz } \\
\text { alguma interferência, ou é muito pouco, assim, um pouco, pouco } \\
\text { elevada, não é aquela coisa tão...então, é melhor ter gasolina, não sei, } \\
\text { entendeu? }\end{array}$ \\
\hline 269 & P1: Quanto será que gasolina é mais cara que o álcool? Quanto será? \\
\hline
\end{tabular}




\begin{tabular}{|c|c|}
\hline 270 & Pedro: Não, tá, mas isso daqui então não, \\
\hline 271 & $\begin{array}{l}\text { P1: Se a gente fosse, por exemplo, se a gente fosse comparar, é, a } \\
\text { porcentagem, assim, do preço da gasolina em relação ao álcool? Se } \\
\text { você procurar, na internet, por exemplo, cê vai ver que o álcool..., } \\
\text { hum, é que daí eu vou falar pra vocês. É que assim, é..., vocês viram } \\
\text { que tem a ver, que quem libera mais energia, rende mais, não viram? }\end{array}$ \\
\hline 272 & Gabriela: Aham. Porque a energia é como o impulso. \\
\hline 273 & $\begin{array}{l}\text { P1: É, quem libera mais energia dá mais rendimento pro motor. E isso } \\
\text { falando do mesmo motor, porque o motor é semelhante, do álcool e da } \\
\text { gasolina, tem pouquinha diferença. Agora, para ver o preço, a gasolina } \\
\text { é mais cara, só que a gasolina rende mais. O álcool é mais barato, só } \\
\text { que ele rende menos. Se a gente comparar, por exemplo, o } \\
\text { rendimento do motor com o preço, será que o álcool é realmente mais } \\
\text { barato? (alunos pensam, em silêncio, por } 7 \text { segundos) }\end{array}$ \\
\hline 274 & Gabriela: Não. \\
\hline 275 & P1: Porque a gasolina é mais cara, só que... \\
\hline 276 & Gabriela: Ela rende, bastante. \\
\hline 277 & P1: Ela rende muito mais. \\
\hline 278 & Gabriela: Compensa mais render mais, do que não render nada. \\
\hline 279 & P1: Então vocês podem pensar: bom, o álcool é mais barato, só que... \\
\hline 280 & Gabriela: Não rende nada. \\
\hline 281 & P1: Não rende... \\
\hline 282 & Gabriela: Não rende. \\
\hline 283 & $\begin{array}{l}\text { P1:...tanto quanto a gasolina. Será que o preço acompanha esse } \\
\text { rendimento? }\end{array}$ \\
\hline 284 & Gabriela: É isso que eu queria saber. \\
\hline 285 & $\begin{array}{l}\text { P1: Como será que a gente pode ver isso? (alunos pensam por } 4 \\
\text { segundos, em silêncio) Aí é uma relação matemática }\end{array}$ \\
\hline 286 & Gabriela: É, aí complica. \\
\hline 287 & $\begin{array}{l}\text { P1: Por exemplo, ó, com licença, (barulho de folhas de papel) se a } \\
\text { gente, por exemplo, é..., falar que..., o rendimento da gasolina é } \\
100 \% \text {. Quanto que vai ser o do álcool? Vai dar um pouco menos, né? }\end{array}$ \\
\hline 288 & Gabriela: Ahan. \\
\hline 289 & $\begin{array}{l}\text { P1: Se a gente fizer a mesma coisa pro preço. O preço da gasolina for } \\
\text { 100\%. Quanto vai ser o do álcool? Será que esses dois valores vão } \\
\text { acompanhar? Será que eles vão dar o mesmo? O mesmo valor? É um } \\
\text { jeito de comparar. }\end{array}$ \\
\hline 290 & Gabriela: Vou fazer aqui rapidinho, pra ver. \\
\hline
\end{tabular}




\begin{tabular}{|c|c|}
\hline 291 & P1: Você chamou? \\
\hline 292 & Gabriela: Chamei. Deu esse resultado aqui, Bia. (inaudível) \\
\hline 293 & $\begin{array}{l}\text { P1: É, na verdade dá } 69 \text { vírgula alguma coisa, que pode aproximar pra } \\
70 \text {. Então quer dizer, o álcool, ele tem, o rendimento dele é } 70 \% \text { do } \\
\text { rendimento da gasolina. Isso quer dizer o quê? Que o preço também } \\
\text { tem que ser } 70 \% \text {, não tem? Pelo menos, se não, não vai compensar } \\
\text { eu abastecer com álcool. Então, tá compensando ou não? (alunos } \\
\text { pensam por } 3 \text { segundos, em silêncio) }\end{array}$ \\
\hline 294 & Pedro: Ah, tá compensando. \\
\hline 295 & $\begin{array}{l}\text { P1: Tá né? Porque o preço tá a menos de } 70 \% \text {. Se o preço estivesse } \\
\text { mais que } 70 \% \text {, aí não taria compensando. }\end{array}$ \\
\hline 296 & $\begin{array}{l}\text { Gabriela: Mas, tipo assim, mesmo compensando, em comparação co, } \\
\text { com a gasolina, a gasolina ainda é melhor, né? }\end{array}$ \\
\hline 297 & $\begin{array}{l}\text { P1: Então, depende, se algum dia você for abastecer seu carro, e o } \\
\text { preço estiver mais que } 70 \% \text {, o preço do álcool } 70 \% \text { do da gasolina, aí, } \\
\text { a gasolina que tá compensando. }\end{array}$ \\
\hline 298 & Gabriela: É. \\
\hline 299 & P1: Se o preço do álcool estiver abaixo de $70 \% . .$. \\
\hline 300 & Gabriela: Aí compensa o álcool. \\
\hline 301 & P1: É, aí o álcool que tá compensando. \\
\hline 302 & Gabriela: E esses preços são verídicos? \\
\hline 303 & $\begin{array}{l}\text { P1: É, eu peguei, ó: posto Vila Tibério, Ribeirão Preto, um posto do } \\
\text { lado da minha casa. }\end{array}$ \\
\hline 304 & $\begin{array}{l}\text { Gabriela: E essa coisa de que, tipo assim, o álcool não compensa? } \\
\text { Então não é verdade isso?... Âs vezes é ilusório a gente ver um..., só } \\
\text { porque tem uma quantidade menor aqui (falando do preço), que roda } \\
\text { e que gasta... }\end{array}$ \\
\hline 305 & P1: É, depende do preço. De como vai tá o preço naquele dia. \\
\hline
\end{tabular}

O episódio 8 pode ser considerado como o retorno ao concreto, pois os alunos estavam imersos na atividade de cálculo de variação de entalpia, na redução abstrata da verificação da energia liberada pelo combustível e, ao objetivar a atividade de cálculo de entalpia passam a reorganizar a atividade de verificação do rendimento dos combustíveis no motor a álcool e a gasolina a partir dos valores de entalpia obtidos, reorganizando uma atividade que pertence ao concreto concernente ao contexto social do aluno, dentro da 
atividade de verificação econômica da escolha de um carro. Dessa forma este movimento da atividade proporciona relação entre conceitos científicos, tecnologia e o uso dessa tecnologia na sociedade, ou seja, relações CTS.

Para esta pesquisa, é importante que a apreensão do modo geral de cálculo de variação de entalpia, bem como o da reação de combustão não sejam apenas uma ação qualquer, sem um motivo ligado à realidade históricosocial do aluno, ou apenas ligado ao motivo do vestibular, para que a educação possa transformar a sua percepção sobre a realidade concreta.

A entalpia de combustão/energia liberada pelos combustíveis intenciona ser o conceito científico principal em processo de apropriação, cujo entendimento por parte dos alunos só pôde ser observado pela professora nas anotações dos alunos do cálculo de entalpia, registrados no caderno.

\subsubsection{Concretização e sistematização (episódio 8: Relações entre os fatores energético e econômico no posicionamento da escolha entre álcool e gasolina)}

Se no episódio anterior os alunos se apropriaram, socialmente, da forma geral do conceito de variação de entalpia, sem se utilizarem de conceitos espontâneos, agora, voltam a fazer relações desse sistema conceitual abstrato com conceitos espontâneos, em via de mão dupla, sendo uma mão a concretização e a outra, a sistematização. Os principais conceitos espontâneos, dentro das nossas considerações, no episódio 8, referem-se, além dos referidos no episódio 5, aos termos compensar, carro, rodar, rodar mais, barato, caro, preço, render, rendimento, motor, explosão, queimar, bastante, nada. Os quais perpassam o diálogo proporcionando concretude aos conceitos científicos aqui considerados como entalpia, energia, liberar energia, reação de combustão, comparação matemática, porcentagem, os quais, no processo da atividade necessitam da concretude dos conceitos espontâneos para sua sistematização dentro do sistema conceitual científico, e neste processo, sistematizam os conceitos espontâneos. Em nossa opinião a concretude torna-se uma necessidade dos alunos.

Consideramos que no turno (T.) 212 "E no caso aqui do meu, do álcool, deu menos 1236. Aí pra responder que é..., qual dos dois compensa mais é, 
quando libera mais, é mais? É melhor? Quando libera menos é melhor? Como é que é?" o aluno expressa a necessidade de significar o valor de energia no concreto, ou seja, uma necessidade de concretização do abstrato, para poder interpretá-lo dentro do problema concreto. Nos turnos que se seguem a professora busca atender esta necessidade utilizando-se de conceitos espontâneos e retomando o problema concreto. A objetivação da necessidade pelo aluno se dá em T. 217 "Pra compensar mais tem que liberar mais calor".

Esta conclusão é mediada de forma que os valores de entalpia sejam comparados aos rendimentos dos motores, até que os alunos percebam que 0 combustível que libera mais energia apresenta maior rendimento no motor. Este processo ocorre a partir de T. 219 a T. 234 e utiliza-se de conceitos espontâneos e de dados de rendimento dos motores 1.0 a álcool e a gasolina (tabela 2, apêndice A).

No entanto, Gabriela coloca uma dúvida sobre o conceito de "liberar energia" (T. 237), expressando sua incompreensão e, a nosso ver, uma necessidade de concretização do mesmo. A qual, é objetivada por meio da explicação de $\operatorname{Max}$ (T. 241), que se utiliza de conceitos espontâneos e científicos de modo a proporcionar concretude à incompreensão de Gabriela sobre a liberação de energia (T. 242).

A necessidade de verificação do preço dos combustíveis é retomada por Gabriela (T. 244), o que revela a reprodução, em si mesma, do motivo da atividade. Porém, somente por meio da mediação da professora, a comparação matemática entre o rendimento do motor e o preço dos combustíveis é apropriada pelos alunos, em T. 292 e, somente por meio da mediação da professora essa comparação é compreendida em T. 294 e T. 300. Isso nos reforça a ideia de que a atividade humana é mediada socialmente, logo, a atividade de ensino-aprendizagem deve proporcionar a mesma mediação. Entre alunos e alunos e professores.

A atividade de verificação do preço dos combustíveis é baseada na realidade histórico-social do aluno e a base de sua mediação utiliza-se da linguagem com conceitos espontâneos. O sistema conceitual científico com os quais os conceitos espontâneos se relacionam é o cálculo percentual de 
comparação de valores, composto por três comparações: a comparação entre o rendimento dos motores (álcool e gasolina), a comparação entre o preço dos combustíveis (álcool e gasolina) e a comparação do preço relativo do álcool ao rendimento relativo do álcool. Percebemos que a aluna já tinha internalizado em si, um sistema simples de comparação percentual composto por uma comparação, de modo a reproduzi-lo no nível das operações (T. 290 e 292) sem a ajuda da professora e rapidamente. Porém, este configurava o seu conhecimento limite e a extensão do sistema para três comparações teria que ser mediada pela professora. O que ocorre de T. 293 a T. 300. Acreditamos que este processo contribui para a sistematização dos conceitos espontâneos álcool, gasolina, rendimento, preço, barato, caro, compensar, e do aumento da sistematização do sistema conceitual matemático de comparações percentuais, bem como sua concretização pelos conceitos espontâneos.

A verificação do preço dos combustíveis por meio dos rendimentos dos motores trabalha com a aparência dos preços, que tem sempre o álcool como mais barato em relação a gasolina, mas o sistema matemático de comparação do rendimento dos motores a álcool e a gasolina revela o porquê da aparência de o álcool ser mais barato e revela que esta aparência pode enganar o consumidor. Sendo este um exemplo de sistematização do conceito espontâneo de álcool por um sistema conceitual científico, assim como o uso da representação do álcool como combustível na reação de combustão e no cálculo de entalpia também o sistematizam ao mesmo tempo em que ele fornece concretude a estes sistemas sendo um conceito cotidiano.

\subsubsection{Significação (episódio 8: Relações entre os fatores energético e econômico no posicionamento da escolha entre álcool e gasolina)}

O episódio 8, por ter a característica de pertencer à realidade históricosocial do aluno e por isso estar carregado de conceitos espontâneos, as significações, em sua maioria, acompanham as concretizações e sistematizações, e ocorrem na aproximação com o sentido pessoal.

Podemos observar a manifestação do sentido pessoal dos alunos nos turnos 214, 215, 233, 234, 245, 276, 278 e 280, a aproximação entre sentido pessoal e significado dos conceitos nos turnos 217 e 272; a reprodução de 
significados nos turnos 229, 231, 241. Consideramos como significações tanto as aproximações entre sentido pessoal e significado quanto os turnos de reprodução do significado, pois estas manifestações coincidem com os significados dos conceitos científicos envolvidos.

Acompanhando a necessidade de concretização do conceito de liberação de energia, o turno 212, transcrito no item anterior, revela, também, a necessidade de significação do conceito de liberação de energia por Rafael. Entendemos que o significado de um conceito científico, por ser o domínio da experiência da humanidade, refletida e generalizada (LEONTIEV, 1983), requer a apropriação de seu sistema conceitual, pois aquilo que o sujeito pensa e compreende pode não coincidir com o significado do conceito, sendo representado pelo seu sentido pessoal (MOURA e MORETTI, 2011). Logo, a significação requer tanto a sistematização quanto a concretização. Dessa forma, o processo de formação dos conceitos nas atividades de ensinoaprendizagem é o processo de sua significação, com relações de generalidade que vão desde o interior de seu sistema conceitual científico até a realidade concreta histórico-social do aluno.

Entendemos que a mediação da professora no turno seguinte (213) busca se aproximar dos sentidos pessoais, cotidianos, dos alunos, a fim de promover a aproximação entre sentido e significado, assim como ocorre com a concretização proporcionada pelos conceitos espontâneos e a sistematização desses pelos conceitos científicos. Assim, no T. 217 consideramos que há uma aproximação entre sentido e significado em relação ao conceito de liberar energia.

Da mesma forma, a necessidade de significação sobre o conceito de liberação de energia no T. 237 por Gabriela, revela aproximações entre sentidos e significados por Max, no T. 241. No entanto, há uma diferença entre a mediação de Max neste turno e a mediação da professora em T. 213 e 216: a mediação de Max fornece um conjunto de conceitos necessários para a objetivação da necessidade de Gabriela, mas é ele quem reproduz, na fala, as relações entre os conceitos e as significações. Já a mediação da professora para necessidade de Rafael, faz com que Rafael, não ela, reproduza as 
relações entre os conceitos e a significação. Este tipo de mediação da professora é intencional. Intenciona a mediação da aprendizagem do aluno e, permeia a maioria de seus turnos, exceto aqueles em que, por reconhecer as limitações dos alunos, fornece os conceitos e suas formas de ação para o aluno as reproduzir.

Em T. 272, Gabriela expressa uma relação entre energia e impulso, demonstrando uma assimilação referente à explicação de Max, mas que a nosso ver está mais próximo ao sentido pessoal do que ao significado do conceito de energia, não deixando, entretanto, de ser uma aproximação entre sentido e significado.

\subsubsection{Generalização (episódio 8: Relações entre os fatores energético e econômico no posicionamento da escolha entre álcool e gasolina)}

No episódio 8, o conceito de entalpia, em sua forma de energia liberada pelo combustível, representada por seus valores, é generalizada para além do sistema conceitual do cálculo de entalpia, ao sistema de valores de rendimento dos motores à álcool e gasolina. Este ato de generalização, de uma estrutura de generalização a outra, é parte do desenvolvimento do conceito (VIGOTSKI, 2009). Este processo decorre da necessidade da atividade em analisar qual dos combustíveis compensa mais economicamente, e compõe uma das ações para objetivação da atividade. Esta generalização tem início desde a necessidade expressa por Rafael em T. 212 e estende suas relações com o rendimento do motor até o primeiro período de T. 273. Neste processo a energia liberada é comparada aos rendimentos dos motores e esta comparação gera relações de generalidade com o fator econômico em T. 217, com o funcionamento do motor e com o movimento do carro, em T. 241. Aos poucos, o termo "liberar mais energia" vai sendo vinculado ao termo "rende mais", e os valores dos rendimentos dos motores são comparados com os preços dos combustíveis para a objetivação da atividade.

Este conceito científico escolar de energia, necessita, nesta atividade, ser mediado com o conceito de rendimento do motor. Aqui, o conceito de rendimento do motor é apresentado como instrumento mediador e na forma de 
dado tabelado retirado do site do INMETRO 27, ou seja, um instrumento que deveria auxiliar a comparação entre custos de combustíveis. Dessa forma, o conceito de entalpia vai sendo generalizado na medida em que faz relações com outros conceitos. Ou seja, intenciona-se que o conceito científico escolar (entalpia) proporcione sistematização aos conceitos da realidade concreta (valores de rendimento do motor) e estes, proporcionem concretude ao conceito de entalpia. (VIGOTSKI, 2009)

Os conceitos de combustível, álcool e gasolina, antes vinculados a conceitos do sistema conceitual da combustão, a conceitos do sistema de cálculo de entalpia, transitam entre todas as estruturas de generalização presentes na atividade, estabelecendo relações de generalidade entre e dentro de cada sistema conceitual. Estabelecem relações com seus valores de energia liberada (a partir de T. 207), com seus valores de rendimento do motor (a partir de T. 222) e com o sistema de comparação percentual entre estes valores (T. 287), e relações com o preço de mercado (T. 244) e com o sistema de comparação percentual (T. 293). Ou seja, o conceito de combustível tem suas características e nexos cada vez mais generalizados e sistematizados dentro da atividade. $O$ aluno os generaliza em vários sistemas conceituais sistematizando-os.

No turno 241, Max generaliza o conceito de energia para além de seu sistema conceitual científico. Faz a transição do conceito de energia deste sistema ao sistema de funcionamento do motor a combustão, estabelecendo relação condicional entre maior liberação de energia e maior rendimento do motor, a sistematização de conceitos pertencentes ao conhecimento cotidiano do aluno por meio de conceitos científicos escolares e a aproximação entre sentidos e significados.

\footnotetext{
27 Rendimento do motor 1.0 Wolkswagen UP! 2015 (INMETRO) http//www.inmetro.gov.br/consumidor/pbe/veiculos_leves_2014.pdf - acesso em 03/08/2015
} 


\subsubsection{Apropriação (episódio 8: Relações entre os fatores energético e econômico no posicionamento da escolha entre álcool e gasolina)}

No episódio 8 as formas histórico-sociais da atividade a serem apropriadas para a sistematização, generalização e significação dos conceitos são basicamente comparações entre características desses conceitos. Os valores de entalpia são comparados entre si e com os rendimentos dos motores para vincular a característica energética dos combustíveis aos rendimentos dos motores, ou seja, vincular um sistema conceitual ao outro na promoção do desenvolvimento do conceito de entalpia no contexto históricosocial, o que transcorre até T. 273.

Já em T. 271 e 273 a necessidade da forma de ação de comparação entre rendimento e preço dos combustíveis é introduzida pela professora, mas não é apropriada pelos alunos. Em T. 283 a T. 285 a mesma necessidade é recolocada e, apropriada por Gabriela, porém, a aluna revela sua limitação em identificar e executar a ação, de modo que a professora a fornece, em T. 287, T. 289 e em T. 293. A aluna reproduz suas apropriações em T. 292 e T. 300, e Pedro em T. 294.

No episódio 8 percebemos que a professora não se atentou para o fato de que a energia térmica liberada pelos combustíveis não é a responsável pelo movimento do motor. Este movimento é causado pela grande diferença entre os volumes dos produtos da reação de combustão em relação aos reagentes. O grande volume de gases produzidos são os responsáveis por mover os pistões dos motores.

Podemos caracterizar este equívoco como uma lacuna na relação entre o conhecimento científico sobre entalpia e o conhecimento da professora sobre o funcionamento do motor. Ou seja, apesar de operar com o conceito de entalpia em contextos escolares, e apesar de compreender que o movimento dos pistões é causado pelos gases, o vínculo ou não vínculo entre esses dois sistemas conceituais não tinha sido apropriado pela professora. O que nos mostra a necessidade de corrigir este equívoco junto aos alunos, e a necessidade de reformulação da atividade neste ponto. 
Ao contrário de opiniões imediatistas que poderiam invalidar a aplicação desta atividade, consideramos este ocorrido como uma oportunidade de avaliação e reformulação da atividade de ensino-aprendizagem pelo professor e pelos alunos, ou seja, uma oportunidade de transformação e aprofundamento do conhecimento de ambos.

De acordo com Leontiev (1983) o conceito de trabalho possui um caráter ontológico de constituição do ser humano. No caso do professor, seu trabalho reproduz e produz sua constante formação em meio a atividade de ensinar e aprender. $\mathrm{O}$ mesmo podemos dizer se considerarmos o trabalho do aluno como sua atividade de estudo. Nesta relação entre professor e aluno, ambos se transformam. $O$ aluno é transformado ao apropriar-se do conhecimento produzido pela humanidade. O professor em sua atividade de ensinar apropriase de novos meios sobre como ensinar, por meio do aluno. Estes novos meios transformam sua prática de ensino e seu próprio conhecimento teórico sobre os conceitos a serem ensinados, o que só pode se concretizar em atividade de práxis, em um constante aprimoramento da relação entre a toria e a prática.

Percebemos que o aprimoramento do conhecimento sobre o conteúdo escolar a ser ensinado é proporcionado pela busca do professor por novas atividades de ensino que generalizam conceitos em novos contextos, sendo 0 contexto histórico-social do aluno um contexto desafiador, que cria novas necessiadades de aprimoramento do ensino-aprendizagem.

Assim, de acordo com o observado nesta atividade, depreendemos que a busca do professor para incluir em sua prática de ensino os vínculos entre conceitos químicos e a realidade histórico-cultural do aluno pode proporcionar essa transformação e aprimoramento em seu trabalho, desde que os equívocos sejam vistos como oportunidades de avaliação. 


\subsubsection{Análise da segunda etapa da sequência de atividades ${ }^{28}$}

Após os alunos terem tentado responder qual combustível compensa mais economicamente, P1 guia a socialização dos resultados obtidos pelos grupos de forma semelhante à realizada no episódio 8, com a exposição dos valores de energia obtidos pelos alunos, dos preços do álcool e da gasolina e da esquematização dos cálculos de comparação entre os rendimentos do motor e os preços dos combustíveis na lousa.

Após esta socialização, propõe um intervalo de 10 minutos para a aula, e, ao retornar, apaga a lousa e escreve as reações químicas balanceadas das combustões do álcool, gasolina e biodiesel, uma ao lado da outra, para usá-las como instrumentos de mediação na próxima etapa do problema, que pretende relacionar as mesmas reações de combustão utilizadas pelos alunos para o cálculo de entalpia, principalmente seus coeficientes de balanceamento, na verificação da questão sobre qual dos combustíveis é mais poluente em relação à liberação de $\mathrm{CO}_{2(\mathrm{~g})}$.

Estas interações se dão entre P1 e a classe como um todo, com intervenções de P2 e P3, como mostra o episódio 9. Neste episódio, P1 tenta estabelecer o primeiro aspecto controverso planejado para a aula: a demonstração de que o biodiesel, amplamente divulgado como um combustível "limpo", é o combustível que tem maior liberação de dióxido de carbono, bem superior à da gasolina.

Episódio 9 Etapa 2 "a" do problema. Relação entre os conceitos de reação de combustão, balanceamento da reação e implicações ambientais da liberação de $\mathrm{CO}_{2(\mathrm{~g})}$ dos combustíveis analisados.

\begin{tabular}{|c|l|}
\hline Turno & Interações discursivas \\
\hline 471 & $\begin{array}{l}\text { P1: Pessoal, vamos retomar e ir pro item 2? (Alunos continuam } \\
\text { conversando) O item 2 dá pra gente fazer junto, né? Pessoal, o item } \\
2\end{array}$ \\
\hline 472 & P3: Galera! \\
\hline
\end{tabular}

28 (apêndice A, item 2. O Problema, etapa 2) 


\begin{tabular}{|c|c|}
\hline 473 & $\begin{array}{l}\text { P1: A gente vai observar uma coisa que também se observa pela } \\
\text { reação. A mesma reação que foi útil pra vocês calcularem a energia, } \\
\text { com os dados vocês calcularam a energia, que são o quê? As } \\
\text { substâncias, os balanceamentos, né? Por esse mesmo, como eu } \\
\text { posso falar, por essa mesma fonte de informação (aponta para as } \\
\text { reações escritas na lousa), que são as reações de combustão de } \\
\text { cada um, a gente pode ver, é..., a quantidade de } \mathrm{CO}_{2} \text { liberada. Só } \\
\text { que, primeira coisa, qual que é o problema da liberação de } \mathrm{CO}_{2} \text { ? }\end{array}$ \\
\hline 474 & Aluna: Poluição \\
\hline 475 & P1: Poluição? Por quê? \\
\hline 476 & Aluna: Porque... \\
\hline 477 & P1: Poluição, como? \\
\hline 478 & Vivian: (inaudível) afeta a camada de ozônio, efeito estufa \\
\hline 479 & Maria: Porque intensifica o gás carbônico, retém calor \\
\hline 480 & P1: O gás carbônico, ele retém calor \\
\hline 481 & Paulo: Naturalmente a Terra gera dióxido de carbono? \\
\hline 482 & P1: Concorda com a cabeça \\
\hline 483 & $\begin{array}{l}\text { Paulo: O problema, então, é como o Franco falou. Ele me corrigiu, } \\
\text { falando que naturalmente o efeito estufa já ocorre. Só que, com a } \\
\text { emissão e o aumento do dióxido de carbono, se eu não tô errado, } \\
\text { é..., intensifica o efeito estufa, por causa da perfuração na camada } \\
\text { de ozônio ( } \mathrm{P} 1 \text { pende a cabeça descordando), e por aí vai }\end{array}$ \\
\hline 484 & P1: Então, mas será que camada de ozônio \\
\hline 485 & P3: Você sabe onde que é o maior buraco na camada de ozônio? \\
\hline 486 & Paulo: Não \\
\hline 487 & P3: Acima da Antártida \\
\hline 488 & Paulo: Acima da Antártida? \\
\hline 489 & Thais: Por quê? \\
\hline 490 & $\begin{array}{l}\text { P3: É o maior buraco que a gente tem na camada de ozônio, então, } \\
\text { vamo tenta pensa se é só isso daí }\end{array}$ \\
\hline 491 & $\begin{array}{l}\text { P1: Quando a gente fala em camada de ozônio, buraco na camada } \\
\text { de ozônio, a gente pensa em outros tipos de poluentes, tá? Os } \\
\text { cloro, flúor carbonados, CFC. O gás carbônico, ele tá mais } \\
\text { relacionado com o efeito estufa, né? Por quê? É, não é o gás } \\
\text { carbônico que vai quebrar o ozônio e vai dispersar o ozônio e formar } \\
\text { um buraco na camada, né, vai ser esses CFCs, tá? Então, o gás } \\
\text { carbônico, ele é relacionado mais com o aquecimento global, efeito } \\
\text { estufa, né, a gente não precisa nem ir muito longe. É, por exemplo, } \\
\text { se tiver, um centro urbano como Ribeirão, que além de ser um } \\
\text { centro urbano, é um buraco }\end{array}$ \\
\hline
\end{tabular}




\begin{tabular}{|c|c|}
\hline 492 & Maria: É um buraco (risos) \\
\hline 493 & $\begin{array}{l}\text { P1: Vamos falar assim, é uma depressão, né, é quente pra } \\
\text { caramba. Se a gente escolhesse, por exemplo, só um tipo de } \\
\text { combustível pra ser usado aqui. E a gente visse, por exemplo, ó } \\
\text { (aponta para as reações da lousa) qual seria o ideal? }\end{array}$ \\
\hline 494 & Paulo: O biodiesel \\
\hline 495 & $\begin{array}{l}\text { P1: O biodiesel? (sorrindo/rindo). Se o gás carbônico, a Maria falou, } \\
\text { né, ele retém calor, aumenta, pra aumentar o efeito estufa. Contribui } \\
\text { também, não só pro efeito estufa, mas também pra aumentar a } \\
\text { temperatura de uma pequena região, de um clima de uma região, } \\
\text { pode, né, influenciar nisso. Então aqui, ó (vai até a lousa e aponta } \\
\text { as reações), pela reação, pelo balanceamento }\end{array}$ \\
\hline 496 & Tami: A quantidade de carbono no álcool é menor \\
\hline 497 & $\begin{array}{l}\text { P1: Então, se a gente fosse escolher um combustível aqui pra } \\
\text { Ribeirão? }\end{array}$ \\
\hline 498 & Maria: O álcool \\
\hline 499 & Aluna: O álcool \\
\hline 500 & $\begin{array}{l}\text { P1: O álcool, nesse sentido, pra não aumentar a temperatura, } \\
\text { pensando nesse sentido do } \mathrm{CO}_{2} \text {. O álcool seria melhor. }\end{array}$ \\
\hline 501 & Maria: Não, eu entendi, mas a (inaudível) \\
\hline 502 & $\begin{array}{l}\text { P1: Vocês tão entendendo o porquê? Vocês tão vendo aqui ó } \\
\text { (aponta a reação de combustão do álcool na lousa), o álcool libera } 2 \\
\text { mols de } \mathrm{CO}_{2} \text {, a gasolina libera } 8 \text { (aponta para cada coeficiente } \\
\text { molar), } 8 \mathrm{mols} \text { de } \mathrm{CO}_{2}\end{array}$ \\
\hline 503 & Alunos: E o biodiesel \\
\hline 504 & $\begin{array}{l}\text { P1: E o biodiesel libera 19. Né? (estranhamento dos alunos, } \\
\text { silêncio) }\end{array}$ \\
\hline 505 & Tami: É bem...(não completa a frase) \\
\hline 506 & $\begin{array}{l}\text { P1: } \dot{E} \text { estranho isso, né? O BIO-diesel (ênfase no "bio"), tão } \\
\text { bunitinho, tão verdinho (faz sinal de apertar as bochechas) }\end{array}$ \\
\hline 507 & Vivian: É um diesel, é um diesel isso, mano! \\
\hline 508 & P1: Liberar 19 mols de $\mathrm{CO}_{2}$ (ênfase no 19) \\
\hline 509 & $\begin{array}{l}\text { P1: Então, se a gente for pensar só na liberação de gás carbônico. } \\
\text { Se a gente fosse pensar só nisso, o biodiesel estaria fora de } \\
\text { cogitação }\end{array}$ \\
\hline
\end{tabular}

5.1.6.1 Concretização, sistematização, generalização, significação e apropriação (Episódio 9 Etapa 2 "a" do problema. Relação entre os 
conceitos de reação de combustão, balanceamento da reação e implicações ambientais da liberação de $\mathrm{CO}_{2(\mathrm{~g})}$ dos combustíveis analisados)

O diálogo do episódio 9 tem início com a mediação da professora trazendo a atenção dos alunos para o sistema conceitual científico (VIGOTSKI, 2009) da reação de combustão, mediado também por sua representação na lousa, o qual já passou por concretizações e sistematizações desde o início da atividade. Mas ao mesmo tempo, generaliza os elementos conceituais desse sistema ao conceito de poluição, mais especificamente, generaliza a produção de $\mathrm{CO}_{2(\mathrm{~g})}$ pela reação de combustão com um tipo particular de poluição, significado nas palavras de Maria como retenção de calor. Esta generalização proporciona uma nova concretude e o aumento do grau de sistematização aos conceitos de reação de combustão e dióxido de carbono por meio do conceito de poluição, bem como a sistematização do conceito de poluição por meio do conceito de combustão. Esta generalização contribui para o desenvolvimento do conceito de $\mathrm{CO}_{2(\mathrm{~g})}$ pois proporciona a transição de uma estrutura de generalização (reação de combustão) para outra (poluição, retenção de calor) Vigotski (2009).

O efeito desta generalização na fala dos alunos nos revela que para alguns alunos, o conceito de poluição relacionado ao conceito de emissão de $\mathrm{CO}_{2(\mathrm{~g})}$ está mais sistematizado (T. 479) que para outros (T. 478). Para Maria, já existe a significação, para os segundos não.

A poluição por emissão de $\mathrm{CO}_{2(\mathrm{~g})}$ é associada por Vivian em (T. 478) com efeito estufa e com buraco na camada de ozônio, o que nos indica que a operação com o conceito de poluição tem algum grau de sistematização no cotidiano, senso comum, aproximando a poluição por $\mathrm{CO}_{2(\mathrm{~g})}$ aos conceitos espontâneos. Ao contrário de Maria (T. 479).

Paulo, em T. 483, reproduz o conceito poluição por $\mathrm{CO}_{2(\mathrm{~g})}$ com maior sistematização que Vivian, porém também o associa com o buraco na camada de ozônio, além de colocar este como causa do efeito estufa. O que revela o caráter espontâneo ou de pseudoconceito, do conceito de poluição por $\mathrm{CO}_{2(\mathrm{~g})}$. 
Percebemos que o que diferencia a sistematização de Maria (T. 479) dos demais estudantes é que ela reproduz o princípio genético geral (DAVÍDOV, 1988) do conceito de poluição por $\mathrm{CO}_{2(\mathrm{~g})}$ - a retenção de calor pelo gás.

Em T. 491, 493, 495 e 497, a professora coloca uma questão hipotética, de caráter socioambiental, em um caso particular pertencente ao contexto histórico-cultural dos alunos T. 493 "Se a gente escolhesse, por exemplo, só um tipo de combustível pra ser usado aqui (Ribeirão Preto)...qual seria o ideal?", considerando as colocações anteriores sobre as condições climáticas da cidade e do conceito de poluição por $\mathrm{CO}_{2(\mathrm{~g})}$ liberado pelos combustíveis álcool, gasolina e biodiesel, cujas reações de combustão balanceadas estão escritas na lousa.

Para os alunos, responder a esta questão significa realizar, a partir do

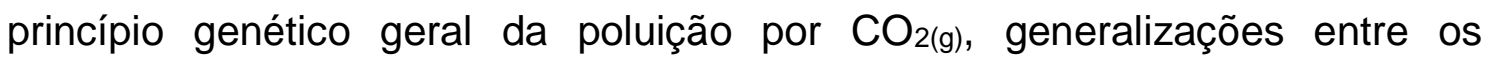
sistemas conceituais de cada reação de combustão ao sistema conceitual de poluição por $\mathrm{CO}_{2(\mathrm{~g})}$. O que implica que se um ou outro sistema não estiver suficientemente sistematizado como conceito científico, a generalização não contribuirá para o processo de formação desses conceitos como conceitos científicos, para a aproximação dos mesmos aos seus respectivos significados, o que é comprovado com a resposta de Paulo em T. 494.

Ao reiterar o princípio genético geral do conceito de poluição por emissão de $\mathrm{CO}_{2(\mathrm{~g})}$ em T. 495, a professora aponta novamente para as reações citando o balanceamento das mesmas. A partir deste momento, os coeficientes estequiométricos/molares, além de serem um conceito científico, tornam-se instrumentos simbólicos para a mediação da questão, de forma que alguns alunos tomam consciência de sua função dentro da reação, e passam a operar com eles. Esta tomada de consciência reconhece a mesma função do coeficiente estequiométrico, seu princípio genético geral, de uma forma diferente da utilizada nas operações de balanceamento da reação. O sistema conceitual em que o coeficiente estequiométrico se encontra é o mesmo - a reação de combustão, porém, a nova questão, inserida em um novo caso particular do contexto histórico-social do aluno requer uma nova generalização. 
A atividade de aprendizagem requer que a generalização contribua para a

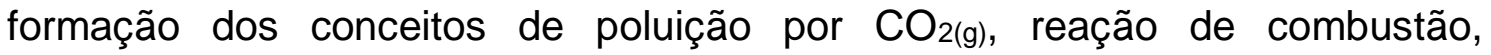
balanceamento da reação e coeficientes estequiométricos/molares, e requer que, esta sistematização, ao mesmo tempo, proporcione mudanças na percepção da realidade concreta pelos alunos sobre a poluição causada pelo uso dos combustíveis.

Assim, a necessidade de generalização entre reação de combustão de

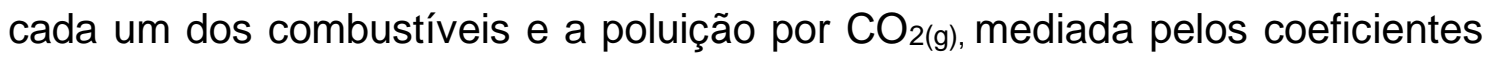
estequiométricos permite Tami, em T. 496 a fazer uma assimilação favorável a esta generalização. E, Maria, em T. 498 e outra aluna em T. 499 a reproduzir a generalização necessária para a objetivação da questão, o que contribui para o desenvolvimento dos conceitos envolvidos, de modo que esta generalização corrobora com a significação dos mesmos.

Em T. 502 a professora, por meio dos coeficientes molares enfatiza a função e o significado dos mesmos na reação e na poluição, com a intensão de mudar a percepção dos alunos sobre o biodiesel, no sentido de iniciar a desconstrução do slogan "energia limpa", concernente a associação do discurso hegemônico entre biocombustível e energia limpa.

Percebe-se que, a sala fica em silêncio, os alunos estranham, e para Vivian, em 507, o sentido de biodiesel muda, quando expressa "É um diesel, é um diesel isso aí, mano!", comparando-o com o diesel. Sabemos que a poluição desses dois combustíveis é diferente e esta comparação se aproxima do sentido de o diesel ser conhecido como um combustível poluente.

Neste caso, um sistema de conceitos da química serve de instrumento para revelar uma controvérsia sociocientífica do contexto histórico-social do aluno, promovendo tomada de consciência de ambas as partes e da relação entre as partes, de modo a contribuir para a transformação da realidade objetiva.

Isso nos indica que a utilização de aspectos controversos pode ser um instrumento da atividade de aprendizagem que contribui para a mudança de sentidos e o desenvolvimento de significados de conceitos, e que as 
controvérsias podem ser instrumentos mediadores junto a outros instrumentos, para promover a generalização dos conceitos presentes entre sistemas de relações de generalidade, contribuindo para o desenvolvimento dos mesmos no aluno.

\section{Movimento da atividade}

O movimento da atividade de verificação sobre qual dos combustíveis é mais poluente em função da emissão de $\mathrm{CO}_{2(\mathrm{~g})}$ é um movimento que parte do abstrato e ascende ao concreto.

O abstrato, considerado como o conjunto de sistemas conceituais das reações de combustão, representado na linguagem simbólica da química. 0 concreto, considerado como o conceito de poluição ambiental, o qual tem a característica de estar presente no discurso cotidiano, no contexto social.

No caso, a observação de um sistema conceitual da química, de suas relações de generalidade, leva, a objetivação da necessidade externa a este sistema - verificação de qual combustível é mais poluente. Necessidade que se encontra no contexto social. Este movimento promove relações CTSA entre conceitos químicos como reação de combustão, coeficientes estequiométricos da reação; o slogan da tecnologia dos biocombustíveis, como energia limpa, representada pelo biodiesel e álcool; e a poluição por $\mathrm{CO}_{2(\mathrm{~g})}$ e sua influência no aquecimento de uma cidade, região e aquecimento global.

O próximo episódio, episódio 10, pretende enfatizar a questão da renovabilidade dos combustíveis álcool e biodiesel em comparação a não renovabilidade da gasolina. No episódio 9 o biodiesel está sendo apontado como o mais poluente dentre os três, enquanto que, no episódio 10, esta característica pretende ser voltada para a gasolina.

A discussão do episódio 10 estabeleceu relações entre o ciclo do carbono e a absorção natural de $\mathrm{CO}_{2(\mathrm{~g})}$ liberado pelos combustíveis. Os alunos estabeleceram dois grandes diálogos sobre renovabilidade versus não renovabilidade dos combustíveis, um no primeiro dia e outro no início do segundo dia, quando a aula do dia anterior é retomada, como rotina do projeto 
CIMEAC, na tentativa de se estabelecer a revisão da linha de raciocínio da aula anterior e manter continuidade para o segundo dia de aula.

No segundo dia de aula, contamos com a presença de P4, biólogo, mestre em ensino de ciências, com a ausência de alguns alunos que compareceram no primeiro dia e o contrário. Nicolas é um dos alunos que compareceu somente no segundo dia e, nesse episódio, é interessante observar como entende e expressa suas assimilações com a ajuda dos colegas e de $\mathrm{P} 1$, sobre o conceito de renovabilidade, o que se segue no episódio 10.

Episódio 10: Etapa 2 "b" do problema. Renovabilidade dos combustíveis.

\begin{tabular}{|c|c|}
\hline Turno & Interações discursivas \\
\hline 689 & $\begin{array}{l}\text { P1: O que que vocês lembram da liberação de } \mathrm{CO}_{2} \text { ? Por que que é } \\
\text { importante, é, saber, o quanto libera de } \mathrm{CO}_{2} \text { ? }\end{array}$ \\
\hline 690 & $\begin{array}{l}\text { Paulo: Pelos impactos que tem no meio ambiente. Só que eu falei } \\
\text { demais, o pessoal também pode fortalecer }\end{array}$ \\
\hline 691 & $\begin{array}{l}\text { P1: Qual é o problema maior do } \mathrm{CO}_{2} \text { ? Muito } \mathrm{CO}_{2} \text { liberado no } \\
\text { ambiente? }\end{array}$ \\
\hline 692 & Vivian: Retenção de calor \\
\hline 693 & P1: Retenção de calor (concordando), ...? \\
\hline 694 & Pietro: Doenças respiratórias \\
\hline 695 & $\begin{array}{l}\text { P1: Será que } \mathrm{CO}_{2} \text {. Será que doenças respiratórias não estaria mais } \\
\text { ligado com } \mathrm{CO} \text { ? Monóxido? }\end{array}$ \\
\hline 696 & Paulo: Porque ele é muito estável com a ..., hemoglobina \\
\hline 697 & $\mathrm{P} 1: \mathrm{O} \mathrm{CO}_{2}$ tem mais a ver com o aquecimento global \\
\hline 698 & $\begin{array}{l}\text { Tami: } \mathrm{O} \text {, Bia, o } \mathrm{CO}_{2} \text { também tem alguma coisa a ver com a chuva } \\
\text { ácida? }\end{array}$ \\
\hline 699 & P1: Não entendi? \\
\hline 700 & Dani: $\mathrm{O} \mathrm{CO}_{2}$ tem influência na chuva ácida? \\
\hline 701 & $\begin{array}{l}\text { P1: É tem também, pode formar o ácido carbônico, mas ele é bem } \\
\text { fraco, o ácido carbônico. Ele não chega assim, a estragar... }\end{array}$ \\
\hline 702 & Tami: ser corrosivo, acabar (inaudível) \\
\hline 703 & P1: É. Então a gente viu esses pontos. \\
\hline 704 & (falas paralelas retiradas) \\
\hline 70 & $\begin{array}{l}\text { Paulo: Uma dúvida. É meia boba, mas porque a gasolina é "não } \\
\text { renovável"? }\end{array}$ \\
\hline
\end{tabular}




\begin{tabular}{|c|c|}
\hline 706 & P1: Porque a ga..., alguém ajuda o Paulo aí \\
\hline 707 & Vivian: Porque ela é um combustível fóssil \\
\hline 708 & $\begin{array}{l}\text { P1: Mas só, só por isso? (silêncio) O que que acontece que a } \\
\text { gasolina não é renovável? Os derivados de petróleo, são fósseis...? }\end{array}$ \\
\hline 709 & $\begin{array}{l}\text { Tami: Ocorre todo um processo pra, para essa transformação. } \\
\text { Através das rochas sedimentares. Aí vai acontecendo, demora, } \\
\text { pressão, tem influência da pressão do solo, temperatura, e eles ficam } \\
\text { bem profundo, então, esse processo leva milhares de anos. Então } \\
\text { por isso que é chamado de um combustível não renovável. }\end{array}$ \\
\hline 710 & P1: Uhum \\
\hline 711 & Nicolas: Mas é mais por causa do tempo? \\
\hline 712 & $\begin{array}{l}\text { P1: Por exemplo, em toda a sua vida você nunca vai presenciar a } \\
\text { formação do petróleo. O petróleo que você queimou, né, é uma coisa } \\
\text { assim de milhares e milhares de anos. Fala Janaína }\end{array}$ \\
\hline 713 & Janaína: O dia que acabar, acabou \\
\hline 714 & Nicolas: Mas ele não vai voltar? \\
\hline 715 & $\begin{array}{l}\text { P1: É, porque o álcool e o biodiesel, no caso que a gente tá vendo, } \\
\text { eles podem ser, num tempo não muito longo, eles podem ser } \\
\text { replantados, né, e a fotossíntese capta o } \mathrm{CO}_{2} \text { que eles liberaram. A } \\
\text { gasolina não. A gasolina, liberou, vai acumular na atmosfera }\end{array}$ \\
\hline 716 & $\begin{array}{l}\text { Nicolas: Ah, tipo assim, ali ele não volta, no caso, então? Então o } \\
\text { álcool, ele libera e depois (inaudível) ele volta. A gasolina, vai ficando } \\
\text { acumulado. Daí é esse o sentido de ser renovável, então? }\end{array}$ \\
\hline 717 & P1: Isso \\
\hline 718 & $\begin{array}{l}\text { Janaína: O negócio do derivado de petróleo é a matéria prima, que } \\
\text { não é renovável (inaudível). E a matéria prima do álcool e do } \\
\text { biodiesel a gente pode replantar. Pode plantar e fazer uma nova leva. } \\
\text { Plantar de novo mais uma nova leva. Petróleo não, cê tem que } \\
\text { extrair. O dia que acabar, essa reserva não vai dar mais pra fazer o } \\
\text { que }\end{array}$ \\
\hline 719 & $\begin{array}{l}\text { P1: É, assim, o álcool, você queima o combustível, depois você vai lá } \\
\text { e planta. O que que a planta precisa pra crescer? }\end{array}$ \\
\hline 720 & Paulo: Oxigênio, água, nutrientes \\
\hline 721 & Aluno: Sol \\
\hline 722 & $\begin{array}{l}\text { P1: Precisa fazer fotossíntese, né, e aí a fotossíntese vai capturar o } \\
\mathrm{CO}_{2} \text {, formando um ciclo, não é? Então esse é o significado de } \\
\text { renovabilidade }\end{array}$ \\
\hline 723 & $\begin{array}{l}\text { Nicolas: Do que ela própria liberou? Que o próprio álcool libera o } \\
\mathrm{CO}_{2} \text {, a planta cresce e pega o } \mathrm{CO}_{2} \text { de volta? }\end{array}$ \\
\hline 724 & P1: (balança a cabeça concordando) \\
\hline 725 & Ah, agora eu entendi. \\
\hline
\end{tabular}




\begin{tabular}{|l|l|}
726 & P1: Aí fecha um ciclo de \\
\hline 727 & $\begin{array}{l}\text { Nicolas: Agora, a gasolina libera e, nada consegue, pelo menos } \\
\text { desse ciclo não consegue pegar de volta? }\end{array}$ \\
\hline 728 & $\begin{array}{l}\text { P1: Demoraria milhares de anos pra formar, milhares e milhares de } \\
\text { anos }\end{array}$ \\
\hline 729 & $\begin{array}{l}\text { Tami: Na realidade é que, o Nicolas, é, por exemplo, não sei se eu tô } \\
\text { enganada, mas, o álcool libera, então, mas a planta, a cana de } \\
\text { açúcar acaba compensando porque ela absorve, no período de } \\
\text { fotossíntese, ela absorve gás carbônico e libera oxigênio, diferente } \\
\text { da gasolina que não tem, como ela não é um combustível renovável, } \\
\text { ela não vem de "uma planta", esse combustível, então, a planta que } \\
\text { surge o álcool automaticamente faz a fotossíntese, diferente da } \\
\text { gasolina que é extraída do próprio solo. Não tem planta suficiente, } \\
\text { talvez, pra suprir essa quantidade de CO } 2 \text { que é liberado..., acho que } \\
\text { é mais ou menos isso }\end{array}$ \\
\hline 730 & P1: Então deu pra entender assim, renovável e não renovável? \\
\hline 731 & Nicolas: Huhum \\
\hline 732 & Thaís: Deu \\
\hline
\end{tabular}

\section{Significação e apropriação}

Logo no início do episódio, em T. 692, podemos observar uma mudança no sentido do conceito de poluição por emissão de $\mathrm{CO}_{2(\mathrm{~g})}$ para Vivian, cuja reprodução coincide com o significado do conceito. No episódio 9, podemos observar que Vivian reproduzia o sentido de poluição por $\mathrm{CO}_{2(\mathrm{~g})}$ em operações de senso comum. No episódio 9 observamos que o significado desse conceito é expresso primeiramente por Maria, T. 479, reiterado pela professora em T. 480 e 495, e agora, apropriado e utilizado deliberadamente por Vivian. Ou seja, temos o resultado de uma atividade coletiva de desenvolvimento do significado do conceito, que não envolve somente as reproduções da professora, mas a participação ativa e produtiva dos alunos na objetivação da atividade de aprendizagem.

A discussão do conceito de renovabilidade dos combustíveis, no episódio 10, é marcada pelo movimento de apropriação do significado desse conceito por Nicolas. Este aluno começa a participar do diálogo colocando dúvidas em T. 711 e 714, relacionadas ao tempo de reincorporação à natureza 
do $\mathrm{CO}_{2(\mathrm{~g})}$ liberado pelo combustível, o que, na verdade, se configura como o princípio genético geral (DAVÍDOV, 1988) do conceito de renovabilidade do combustível.

Observa-se que, com a atividade coletiva de compreender porque a gasolina não é renovável, Nicolas, a partir de T. 716 reproduz assimilações das falas dos colegas e da professora, em um processo de significação do conceito de renovabilidade, o que pode ser observado em T. 716, 723 e 727. De modo que as dúvidas T. 711 "Mas é mais por causa do tempo?" e T. 714 "Mas ele $\left(\mathrm{CO}_{2(g)}\right)$ não vai voltar?" vão sendo transformadas por significações como T. "Então o álcool, ele libera e depois (inaudível) ele $\left(\mathrm{CO}_{2(g)}\right)$ volta. A gasolina, vai ficando acumulado" e T. 727 "Agora, a gasolina libera e, nada consegue, pelo menos desse ciclo não consegue pegar de volta?"

Consideramos que as falas dos demais alunos que contribuíram para a compreensão do conceito de renovabilidade também coincidem com o significado do conceito, pois reproduzem a forma ideal, reduzida ao contexto idiomático de existência das características, nexos e relações do mundo objetal, produzidas histórica e socialmente a partir da objetivação da necessidade humana (LEONTIEV, 1983). No caso, a objetivação dessa atividade consistia justamente na compreensão coletiva do conceito de renovabilidade, que serviu para a objetivação da atividade anterior de verificação de qual combustível é mais poluente e foi retomada no segundo dia de aula.

\subsubsection{Etapas, 3, 4, 5 e 6 da sequência de atividades ${ }^{29}$}

A discussão da renovabilidade dos combustíveis foi também preparatória para a introdução das próximas etapas da atividade, as quais tinham o objetivo de se constituírem como um conjunto de contrapontos à ideia de renovabilidade, e promover a controvérsia central da aula: o slogan da renovabilidade dos combustíveis versus os impactos socioambientais causados

\footnotetext{
${ }^{29}$ Apêndice A, item 2. O problema, etapas 3, 4, 5 e 6.
} 
pela prática do sistema produtivo que fornece esses combustíveis, ou seja, a monocultura extensiva que, necessariamente utiliza sementes transgênicas e agrotóxicos.

Com essas etapas do problema, pretendia-se a tomada de consciência de problemas sociais direta ou indiretamente relacionados aos alunos, e não somente os problemas, mas os nomes dos causadores desses problemas, como empresas e governantes, bem como os nomes das vítimas, como dos trabalhadores do campo que prestam depoimentos do documentário "O veneno está na mesa", incluindo os alunos, que não trabalham no campo, mas consomem alimentos transgênicos com agrotóxicos provenientes do mesmo sistema produtivo dos combustíveis renováveis. Essa foi uma tentativa de abordagem do problema real em sala de aula, a fim de promover sentidos e significados relacionados aos alunos e a incluir a história do aluno na história contemporânea do seu país e da humanidade ${ }^{30}$.

O episódio que se segue refere-se a um diálogo envolvendo toda a classe, P1 e P4, em que foram levantadas as questões presentes nas etapas de 3 a 6, antes da reprodução dos trechos do documentário selecionados para a aula.

Episódio 11 Implicações socioambientais da produção dos combustíveis renováveis praticada no Brasil.

\begin{tabular}{|c|c|}
\hline Turno & Interações discursivas \\
\hline 733 & $\begin{array}{l}\text { P1: Bom, aí a gente chegou nisso, né, que apesar de o biodiesel } \\
\text { liberar bastante } \mathrm{CO}_{2} \text {, ele é renovável. O álcool também é renovável. } \mathrm{E} \\
\text { isso parece uma coisa, assim, que, é, mostra um futuro promissor }\end{array}$ \\
\hline 734 & Paulo: (balança a cabeça discordando) \\
\hline 735 & P1: (risos) Não? Por que não? \\
\hline 736 & $\begin{array}{l}\text { Paulo: Porque é enganação. É pura enganação. Ao mesmo tempo que } \\
\text { o biodiesel é BIO, ele, a monocultura necessária pra fazer o biodiesel } \\
\text { já tá destruindo biodiversidade. Tá destruindo o solo. É renovável, mas } \\
\text { eu acho que não adianta, com todo respeito, bosta nenhuma (risos) }\end{array}$ \\
\hline
\end{tabular}

\footnotetext{
${ }^{30}$ Quando se fala em outros países que não aceitam o cultivo de transgênicos no documentário
} 


\begin{tabular}{|c|c|}
\hline 737 & $\begin{array}{l}\text { Nicolas: É mais ou menos igual emagrecer. Todo mundo quer } \\
\text { emagrecer, mas todo mundo fica tentando uma pílula mágica } \\
\text { Ninguém se reeduca para emagrecer. É mais ou menos como o } \\
\text { combustível. Enquanto o povo não se tocar e começar a poupar, } \\
\text { gastar menos ou se, não dá sinal de vida, não vai resolver nada, } \\
\text { porque vai ter o que mais pra suprir a necessidade, o consumo dele }\end{array}$ \\
\hline 738 & $\begin{array}{l}\text { P1: Tanto o biodiesel quanto o álcool, né, a gente tem tanto a cultura } \\
\text { da cana e a cultura, assim, comparando álcool e biodiesel, até que } \\
\text { assim, falando de biodiversidade da planta, o biodiesel até é mais } \\
\text { maleável, porque assim, o álcool, ele é preso só na cana, só cana } \\
\text { produz álcool, não, quer dizer, aqui no Brasil, o que é adotado, é sć } \\
\text { cana, mas dá pra tirar álcool de beterraba, álcool, aí aqui no Brasil, por } \\
\text { exemplo, eles adotam só cana devido a politicagem e outras decisões, } \\
\text { né, e o biodiesel, já tem regiões que produz da soja, que é uma } \\
\text { monocultura extensiva prejudicial, regiões que vão fazer com babaçu, } \\
\text { regiões que vão fazer de girassol, então depende da região, dá pra dar } \\
\text { uma variada assim, adaptar ao clima da região, mas mesmo assim, va } \\
\text { ser uma monocultura de girassol, vai ser uma monocultura da planta } \\
\text { que vai gerar o óleo e depois o biodiesel, né ... (alunos permanecem } \\
\text { em silêncio) }\end{array}$ \\
\hline 739 & $\begin{array}{l}\text { P1: E, vamos tentar então começar a levantar essa discussão da } \\
\text { monocultura. Como vocês acham que a monocultura prejudica solo, } \\
\text { água }\end{array}$ \\
\hline 740 & Paulo: Empobrece o solo \\
\hline 741 & Janaína: Empobrece o solo \\
\hline 742 & $\begin{array}{l}\text { Paulo: A gente foi numa aula prática com o Helio (professor de biologia } \\
\text { que não está presente) e ele mostrou isso pra gente de maneira } \\
\text { prática. Mas eu queria que as meninas falassem ( } \mathrm{P} 1 \text { não sabia dessa } \\
\text { aula em campo com Helio) }\end{array}$ \\
\hline 743 & $\begin{array}{l}\text { P1: Então falem aí, meninas. Como que a monocultura prejudica o } \\
\text { solo? }\end{array}$ \\
\hline 744 & Thaís: Não só o solo, como a biodiversidade também \\
\hline 745 & P1: Tá, então vocês podem falar do solo, água, biodiversidade, ar \\
\hline 746 & $\begin{array}{l}\text { Vivian: Prejudica porque se você plantar cana de açúcar, ela sempre } \\
\text { vai estar puxando o mesmo ingrediente da terra, (inaudível) e você va } \\
\text { continuar plantando, vai continuar plantando. Vai chegar uma hora que } \\
\text { aquele solo não vai ter mais o nutriente que aquela cana necessita. A } \\
\text { você já tem uma pequena destruição do solo. E a cana de açúcar, são } \\
\text { muito poucos bichinhos que vivem nela. Por exemplo, quando a gente } \\
\text { foi com o Helio, tipo, era uma estradinha de terra que separava uma } \\
\text { área bem..., bem... }\end{array}$ \\
\hline
\end{tabular}




\begin{tabular}{|c|c|}
\hline 747 & $\begin{array}{l}\text { Thaís: É como se fosse uma mini florestinha aqui do lado (gesticula em } \\
\text { sua lateral) e aqui (gesticula para o outro lado) uma plantação de cana. } \\
\text { E daí o Helio pegou, ele tem um negócio branco que faz assim (gesto } \\
\text { de pegador de borboleta) de pegar borboleta. Aí ele pegou e fez na } \\
\text { cana e tipo, saiu uma borboletinha pequinininha, uma coisinha } \\
\text { branquinha assim, que voava. E aí ele passou na outra e daí veio um } \\
\text { mundo de insetos e bichinhos }\end{array}$ \\
\hline 748 & Vivian: Diferentes \\
\hline 749 & P1: Na floresta? \\
\hline 750 & Thaís: Na floresta \\
\hline 751 & P1: E na cana não \\
\hline 752 & Thaís: só a formiguinha e o bichinho \\
\hline 753 & P1: Então empobrece o solo \\
\hline 754 & Janaína: E a fauna também \\
\hline 755 & P1: E a água? \\
\hline 756 & $\begin{array}{l}\text { Janaína: A gente vende água nessas comódities, porque, por exemplo, } \\
\text { a soja consome muita água. E aí a gente quando vende soja, } \\
\text { (inaudível) combustível, quando faz combustível a gente tá, é, deveria } \\
\text { embutir o valor da água que foi gasto. Que é a nossa água indo } \\
\text { embora }\end{array}$ \\
\hline 757 & P1: Você tá falando a água que irriga a soja? \\
\hline 758 & $\begin{array}{l}\text { Janaína: Mas também tem aquela água que é, como fala, contaminada } \\
\text { por agrotóxico, por exemplo, ou (inaudível) }\end{array}$ \\
\hline 759 & Nícolas: Além de também perder muita água também nesse processo \\
\hline 760 & $\begin{array}{l}\text { Paulo: Já foi mostrado no módulo água que o maior consumo de água, } \\
\text { é a agropecuária e a agricultura }\end{array}$ \\
\hline 761 & Nicolas: $70 \%$ agricultura \\
\hline 762 & $\begin{array}{l}\text { P1: E os rios? Assim, além de tirar a água pra irrigar, o que que } \\
\text { acontece? }\end{array}$ \\
\hline 763 & Thaís: Contamina \\
\hline 764 & $\begin{array}{l}\text { Nícolas: Muito agrotóxico pesado, né? Usado na plantação e acaba } \\
\text { escorrendo pro rio }\end{array}$ \\
\hline 765 & P1: Legal. Aí acaba até mudando o pH do rio \\
\hline 766 & $\begin{array}{l}\text { Janaína: É e você perde mata ciliar, por exemplo, que deveria tá ali do } \\
\text { lado do rio. Você coloca uma plantação que tem outro tipo de raiz, } \\
\text { então (inaudível) absorção, a quantidade de água absorvida, }\end{array}$ \\
\hline 767 & $\begin{array}{l}\text { Tami: Assoreamento, erosão, alargamento do rio, dependendo até } \\
\text { seca do rio }\end{array}$ \\
\hline
\end{tabular}




\begin{tabular}{|c|c|}
\hline 768 & $\begin{array}{l}\text { Nicolas: E expansão de outras áreas também. Porque daí fecha aqui, } \\
\text { expande lá na frente, destrói os pedaço de mata que tem também. } \\
\text { Quando eles faz a hidroelétrica, eles (inaudível) interessante que eles } \\
\text { faz esse cálculo, mas eu acho que é até besteira, porque eles tentam } \\
\text { calcular o tanto que eles vai destruir pra tentar compensar, só que eu } \\
\text { acho que é uma bestera, porque, demora mil, milhões de anos pra se } \\
\text { formar o que tá lá. Então eles vão deixar água aqui, água aqui e vão } \\
\text { fechar e o rio vai alargar lá traz assim. Aí destrói culturas ribeirinhas } \\
\text { que moram perto assim, acaba com tudo }\end{array}$ \\
\hline 769 & P1: Vocês vão ver bastante isso na aula de Belo Monte \\
\hline 770 & $\begin{array}{l}\text { Paulo: Um gancho no que ele falou, o Helio disse que quando desmata } \\
\text { pra plantar e fazer monocultura, tem que replantar em outro lugar, } \\
\text { acho que } 50 \text { ou } 25 \text { vezes mais a mesma árvore que foi cortada. Aí faz } \\
\text { o catálogo lá e replanta. Só que, foi provado, por pesquisas científicas, } \\
\text { que às vezes nem } 70 \% \text { da espécie da biodiversidade desse local, em } \\
\text { outro local replantado e reflorestado, volta. Perde } 25 \% \text { ou mais de } \\
\text { biodiversidade. }\end{array}$ \\
\hline 771 & $\begin{array}{l}\text { P1: E dentro da própria monocultura, a biodiversidade dentro da } \\
\text { monocultura? É que é difícil falar MONOcultura e biodiversidade } \\
\text { (ênfase no radical). Mas assim, ó, eu chego, desmato uma floresta, e } \\
\text { coloco só um tipo de planta lá, ou cana, ou soja, ou milho, né, é..., } \\
\text { vocês conseguem lembrar de alguma coisa a mais que tá envolvido } \\
\text { assim, com o tipo, espécie de cana, espécie de soja? }\end{array}$ \\
\hline 772 & $\begin{array}{l}\text { Janaína: Até existe variedades de uma determinada espécie, só que } \\
\text { assim, isso seria adequado com transgênico, por exemplo, você vai } \\
\text { pegar uma espécie que tem tal característica, com outra espécie que } \\
\text { tem tal característica, com outra que tem tal. Aí você junta e faz uma } \\
\text { outra espécie, e planta somente aquela espécie que não existe } \\
\text { naturalmente. E que pode contribuir negativamente para o ambiente. E } \\
\text { aí você diminui ainda mais a variabilidade genética e ainda dá uma } \\
\text { cagada no solo, sei lá }\end{array}$ \\
\hline 773 & $\begin{array}{l}\text { Nícolas: É, você cria coisas, é, no caso, né, você cria com vários } \\
\text { agrotóxicos e tudo mais. Deixa de ser natural. Uma coisa é você ir lá e } \\
\text { construir (inaudível) da natureza, e depois você pegar uma excelente } \\
\text { produção. (inaudível) consome várias coisas, coisas que não faz bem } \\
\text { pro seu corpo, com as químicas, os agrotóxicos que tem nessas } \\
\text { plantas }\end{array}$ \\
\hline 774 & $\begin{array}{l}\text { P1: Huhum, e..., é engraçado assim, como é empregado o uso de } \\
\text { transgênicos e agrotóxicos, eles parecem coisas bem diferentes assim, } \\
\text { mas de onde eles vêm, quem que faz essa semente única, e o } \\
\text { agrotóxico? }\end{array}$ \\
\hline 775 & Nicolas: É réplica, na verdade, de laboratório \\
\hline 776 & P1: E é aqui no Brasil, é o pessoal que trabalha no campo que faz? \\
\hline 777 & Nicolas: Não \\
\hline
\end{tabular}




\begin{tabular}{|l|l|}
778 & $\begin{array}{l}\text { Janaína: Quem trabalha em laboratório (inaudível), trabalha pra } \\
\text { alguma empresa específica, tipo a (inaudível) ou a Monsanto, por } \\
\text { exemplo, que dá muito, muita atenção pra esse tipo de coisa, pra } \\
\text { otimizar o campo }\end{array}$ \\
\hline 779 & P1: Ahan, tem a Monsanto, que é uma empresa... \\
\hline 780 & Janaína: Giiiiiiigantesca \\
\hline 781 & P1: E não é nacional, né? \\
\hline 782 & Janaína: Ela é internacional, não é? \\
\hline 783 & $\begin{array}{l}\text { P1: Ela é Norte Americana. É e aí acaba acontecendo esse negócio } \\
\text { que a gente chama de monopólio, né, das sementes. (vira-se para P4 } \\
\text { e pergunta se quer falar mais alguma coisa sobre os transgênicos) }\end{array}$ \\
\hline 785 & $\begin{array}{l}\text { P4: É..., não, só queria perguntar uma coisa: vocês falaram pelo } \\
\text { menos umas 432 desvantagens da monocultura. Por que que a gente } \\
\text { usa, então? }\end{array}$ \\
\hline 786 & $\begin{array}{l}\text { Vivian: Porque a gente precisa } \\
\text { P4: A gente precisa? }\end{array}$ \\
\hline 787 & $\begin{array}{l}\text { Janaína: Porque é mais fácil, por exemplo, na hora da colheita, mais } \\
\text { agilidade, tal }\end{array}$ \\
\hline 788 & $\begin{array}{l}\text { Pietro: Se tornou, acho que, um meio de produção bem, entre aspas, } \\
\text { natural, assim, né. Então, vamo supor, a gente precisa de uma } \\
\text { determinada planta que só plantando vai ter. E o que tem nos dias de } \\
\text { hoje, os meios de produção é tudo, né, então, pra fazer em larga } \\
\text { escala, pra população, precisa ser uma monocultura, porque é meio } \\
\text { que essa demanda de produção, né? }\end{array}$ \\
\hline 789 & $\begin{array}{l}\text { P1: O que parece, assim, é que não tem outro jeito, né? Tem que ser } \\
\text { monocultura, senão não vai ser suficiente. Tem muuita gente pra } \\
\text { comer }\end{array}$ \\
\hline $\begin{array}{l}\text { Nicolas: E é fácil, também eles lá, plantar uma coisa sabendo que } \\
\text { daqui, vamo supor, uma coisa que eu tenho conhecimento é o frango, } \\
\text { então o frango daqui 6 meses tá pronto (inaudível) cê come um } \\
\text { negócio lá que nem é um frango ainda, é um pintinho lá, que eles } \\
\text { falam, né, nem cresceu, desenvolveu ainda, já tá comendo, então } \\
\text { assim, é uma coisa assim, que ele sabe que vai dar lucro, né. Ele já } \\
\text { sabe, tipo assim, colocou o dinheiro ali, vai dar o lucro pra ele, ele só } \\
\text { quer saber de dinheiro no bolso dele. É o capitalista, né?? }\end{array}$ \\
\hline
\end{tabular}




\begin{tabular}{|c|c|}
\hline 791 & $\begin{array}{l}\text { Paulo: Eu vou tentar trazer um pouco o viés das ciências humanas. O } \\
\text { homem, a passagem do paleolítico pro neolítico teve grande fator } \\
\text { também, trazendo o foco pra agricultura. O homem se apropriou da } \\
\text { agricultura como um meio pra facilitar. Isso foi um dos fatores que } \\
\text { levou ao sedentarismo. Só que, ao decorrer do tempo, foram } \\
\text { ocorrendo várias transformações, várias transformações, antes o que } \\
\text { era pra sobrevivência, se tornou hoje, eu acho que, não culpando o } \\
\text { capitalismo, mas o capitalismo e as transformações geraram que isso } \\
\text { se torne um comércio, como foi falado. E a escala, a proporção } \\
\text { humana, aumentou de uma forma }\end{array}$ \\
\hline 792 & P1: Exponencialmente \\
\hline 793 & Tami: Nós fomos educados pra isso, né? \\
\hline 794 & Nicolas: Mas qual seria o certo, na verdade? \\
\hline 795 & Paulo: Não tem \\
\hline 796 & P1: Será que não tem? \\
\hline 797 & $\begin{array}{l}\text { Tami: Será que não tem? Porque fomos educados pra acharmos que } \\
\text { não tem uma outra opção. Ou realmente não tem uma outra opção? É } \\
\text { complicado }\end{array}$ \\
\hline 798 & $\begin{array}{l}\text { P1: E outra coisa que a gente passou batido, e a vida do trabalhador } \\
\text { do campo? }\end{array}$ \\
\hline 799 & Janaína: Ai, complicado, hein? \\
\hline 800 & P1: O que está plantando a cana que você vai usar no seu carro? \\
\hline 801 & Janaína: Mas que tipo você tá falando \\
\hline 802 & P1: Aquele pessoal do campo, que põe a mão na massa pra trabalhar \\
\hline 804 & $\begin{array}{l}\text { P1: E a vida do trabalhador que tá lá na monocultura? Vocês chutam, } \\
\text { assim, o que acontece com eles, como que é a condição de trabalho? }\end{array}$ \\
\hline 805 & Janaína: Tem CLT, essas coisas? \\
\hline 806 & P1: Pelo que eu sei é contrato temporário, né? \\
\hline 807 & $\begin{array}{l}\text { Tami: O que eu observo muito na minha cidade, que é cidade } \\
\text { pequena, que talvez aqui não tenha muito, é muito nortista vindo, ou } \\
\text { pessoas, tipo, do norte de Minas, quase que divisa com a Bahia, } \\
\text { mesmo, pessoas de Pernambuco, nortista não, nordestino, perdão, } \\
\text { nordestinos, eles vêm muito pra safra. Aí eles trabalham, trabalham, } \\
\text { trabalham, consegue juntar o máximo de dinheiro possível porque eles } \\
\text { vivem em condições precárias, tipo, um quarto com dez pessoas, sei } \\
\text { lá, só pra juntar dinheiro pra mandar pra lá porque lá talvez a condição } \\
\text { de vida seja um pouco mais complicada de arrumar serviço. Aí eles } \\
\text { voltam pra lá, no período entre safras, na parada como eles falam, e } \\
\text { na safra voltam de novo, e ficam sempre no mesmo lugar, por } \\
\text { exemplo, Barrinha }\end{array}$ \\
\hline 808 & Aluna: Sertãozinho? \\
\hline
\end{tabular}




\begin{tabular}{|c|c|}
\hline 809 & $\begin{array}{l}\text { Tami: Nem tanto Sertãozinho, por exemplo, Pradópolis que tem uma } \\
\text { usina muito grande que é a San Martim. Então acabam se } \\
\text { aglomerando sempre nessas cidades, que acabam tendo ônibus que } \\
\text { levam pra esses locais que faz a extração braçal da cana de açúcar }\end{array}$ \\
\hline 810 & $\begin{array}{l}\text { Nicolas: Tem funcionários desse tipo que ficam presos na própria } \\
\text { empresa porque, por causa das dívidas que eles mesmo fazem, } \\
\text { porque é tão precária a situação lá, que o patrão obriga eles a pagar } \\
\text { tudo, suas ferramentas, suas luvas, então eles tem que comprar, então } \\
\text { o que eles, se ele tá recebendo acaba num dando pra pagar essa } \\
\text { dívida, então eles ficam presos no próprio serviço, aí, é como se fosse } \\
\text { assim, num compara a um serviço escravo, mas é como se fosse o } \\
\text { dono deles, no caso }\end{array}$ \\
\hline 811 & $\begin{array}{l}\text { P4: Isso aí que você tava falando, Nicolas, lembra de algum livro que } \\
\text { vocês leram, que tem uma situação desse tipo, assim? }\end{array}$ \\
\hline 812 & Paulo: Vidas Secas? \\
\hline 813 & $\begin{array}{l}\text { P4: Não, disso que ele tava falando, de você trabalhar num lugar que } \\
\text { você tem que pagar pelo treinamento, pelas coisas, e que, você fica } \\
\text { preso, o que você ganha você tem que pagar pro próprio patrão. O } \\
\text { Cortiço, né? João Romão era desse naipe aí }\end{array}$ \\
\hline 814 & $\begin{array}{l}\text { Janaína: Ele pagava o salário, o salário pagava o aluguel e voltava pra } \\
\text { ele }\end{array}$ \\
\hline 815 & $\begin{array}{l}\text { P1: E outra coisa também, vocês falaram do agrotóxico. E o trabalador } \\
\text { que trabalha, o que será que agrotóxico causa, assim, no trabalhador? }\end{array}$ \\
\hline 816 & $\begin{array}{l}\text { Nicolas: Normalmente é jogado por avião, né, não tem nem como } \\
\text { respirar }\end{array}$ \\
\hline 817 & $\begin{array}{l}\text { Tami: Não, também tem algumas pessoas que trabalham com uma } \\
\text { bomba. Fora que a bomba é extremamente pesada, prejudica a } \\
\text { musculatura do braço, e também, normalmente, quem trabalha com } \\
\text { isso, dependendo do local, recebe até periculosidade porque é muito } \\
\text { forte, mesmo tendo os equipamentos, acaba sendo afetado. É..., o } \\
\text { agrotóxico, além de fazer mal pras pessoal que trabalham, acaba } \\
\text { fazendo mal pra gente também porque a gente acaba ingerindo o } \\
\text { alimento com agrotóxico }\end{array}$ \\
\hline 818 & Pietro: E fora que esses negócios fica na terra \\
\hline 819 & Tami: É!, fica no solo, iííí \\
\hline 820 & P1: E pra onde vai os agrotóxicos que são usados por aí? \\
\hline 821 & Aluno: Pro aquífero \\
\hline 822 & Maria: Sem contar que muitas indústrias optam pelas queimadas, né? \\
\hline 823 & Níc \\
\hline
\end{tabular}




\begin{tabular}{|c|c|}
\hline 824 & $\begin{array}{l}\text { P1: Então, gente, vocês percebem também que tudo tá interligado? A } \\
\text { produção de combustível, tudo o que é monocultura, participa dessa } \\
\text { mesma, é..., dessas mesmas condições assim, de ter que comprar } \\
\text { semente transgênica, e usar o agrotóxico da empresa, fazer tudo } \\
\text { conforme a empresa determina. E como é que isso ocorre, porque que } \\
\text { o trabalhador rural, ou mesmo o chefe, ele não pode falar: não, eu não } \\
\text { vou usar esse agrotóxico? }\end{array}$ \\
\hline 825 & $\begin{array}{l}\text { Nicolas: Tipo assim, eu vi um documentário essa semana passada é..., } \\
\text { que fala sobre essa, essa, ah..., tipo..., da dominação dos povos, vamo } \\
\text { dize assim. Então (inaudível) um povo que domina, então ele começa } \\
\text { a implantar que certa, a ideologia dele é bom, então, vamo supor, que } \\
\text { a educação dele é boa, então ir pra escola é bom, porque vai começar } \\
\text { estudar, só que ele vai alimentando a ideologia dele desde pequeno lá, } \\
\text { e ele começa a fazer tudo aquilo que ele quer fazer, entendeu? Então } \\
\text { você caminha, vamo supor, cê vai pra escola hoje em dia, a taxa de } \\
\text { pessoas que reprova é muito alta. E pra onde que eles vão trabalhar? } \\
\text { Vão ser trabalhadores dessas empresas, e tudo mais, deles, } \\
\text { trabalhando pra eles, sem questionar, sem nada, porque não tem } \\
\text { opção }\end{array}$ \\
\hline 826 & P1: E por exemplo, vocês acham que o governo tem a ver também? \\
\hline 827 & $\begin{array}{l}\text { Nicolas: Eu acho que o governo é marionete deles (outros alunos não } \\
\text { se manifestam a esta pergunta) }\end{array}$ \\
\hline 830 & $\begin{array}{l}\text { P1: Bom, legal que a gente levantou isso, e que a gente também } \\
\text { reconhece assim, que, é..., tanto a produção de biocombustíveis, } \\
\text { quanto a de alimentos, é pelo mesmo sistema produtivo. Então eles } \\
\text { tão bem condicionados a isso. Aí, a partir disso eu trouxe, alguns } \\
\text { trechos de um documentário que chama "O veneno está na mesa", } \\
\text { não sei se vocês já assistiram }\end{array}$ \\
\hline 831 & Thaís: Ah, já ouvi falar \\
\hline 832 & $\begin{array}{l}\text { P1: Eu tentei, assim, fazer um resumo de tudo que a gente falou aqui. } \\
\text { Então, assim, queria que vocês prestassem atenção, vissem, } \\
\text { refletissem, tirassem conclusões sobre o que vai passar aí, porque às } \\
\text { vezes a gente fala: ah, agrotóxico, ah, tá prejudicando o trabalhador, } \\
\text { mas a gente não tem assim, uma noção real da coisa }\end{array}$ \\
\hline
\end{tabular}

No episódio 11 os alunos não interagem diretamente com os conceitos da termoquímica, mas reproduzem uma atividade de crítica social e ambiental ao sistema produtivo dos biocombustíveis. A monocultura extensiva torna-se o objeto dessa crítica, a qual os alunos desenvolvem ativamente, motivados pelas controvérsias (QSC) presentes neste modo de produção. 
Quando P1 tenta induzir os alunos a pensarem que o uso dos combustíveis renováveis aponta para um futuro promissor, no turno 733, Paulo imediatamente adianta o processo de colocação da controvérsia, discordando da professora em 734. Mesmo que em 735, P1 tenha tentado manter a ideia inicial perguntando o porquê de Paulo discordar, acaba rindo, dando razão ao aluno, que coloca seus pontos de vista, e, em seguida, Nicolas faz o mesmo, concordando com Paulo, fazendo a professora seguir na direção da opinião dos alunos e iniciar as questões da $3^{\text {a }}$ ação da atividade (Apêndice $A$, item 2. $O$ Problema, etapa 3) em 739, sobre como a monocultura extensiva prejudica o meio ambiente de várias formas.

Em 742, Paulo relata que ele e as meninas (Thaís e Vivian) foram a campo com Helio, outro professor de biologia do projeto CIMEAC e que não está presente naquele momento, e viram essas questões na prática, compartilhando com os demais alunos o que presenciaram. Estes relatos explicam o fato de Paulo discordar prontamente da ideia de renovabilidade ser promissora, antes mesmo de P1 trazer as controvérsias que levariam os alunos a essa discordância.

Até 783, P1 faz o levantamento dos aspectos ambientais da etapa 3, com foco na poluição do solo, da água, na questão da biodiversidade, transgênicos e agrotóxicos e os alunos expressam seu conhecimento sobre os impactos ambientais prejudiciais ao meio ambiente. Algumas falas dos alunos expressam conformismo com o sistema de monocultura justificado por concepções midiáticas de que é algo necessário T. 785, 787, 788, 793. Paulo, em T. 795 afirma que não há outra alternativa. Sentidos que esperamos transformar nas próximas etapas da SAt.

Em 798, P1 introduz a etapa 4 (item 4 do item "O Problema", apêndice A), que chama a atenção para aspectos sociais relacionados aos trabalhadores do campo, dos quais destacamos, em 807 e 809, os exemplos da realidade conhecida por Tami, que inclui exemplos da região de Ribeirão Preto, porém, nem Tami, nem os demais se incluíram como parte do problema social até então. No entanto, em 817, Tami se inclui e inclui os colegas quando expressa "acaba fazendo mal pra gente também porque a gente acaba ingerindo o 
alimento com agrotóxico". Em 826, P1 tenta levantar a discussão sobre aspectos políticos envolvidos no problema, sem muito retorno dos alunos, o que mostra desconhecimento. Situação que também pretendemos mudar.

Após este levantamento, pretendido para preparar os alunos a assistirem aos trechos do documentário, P1 relaciona 0 sistema de monocultura de biocombustíveis e de alimentos como sendo parte do mesmo sistema, já que o documentário trata da produção de alimentos no Brasil, e depois de 832, inicia a reprodução com a ajuda de alguns recursos, incluindo um projetor multimídia, caixas de som e um notebook.

Em certo momento da exibição do documentário, no qual é mostrado um pronunciamento da então ministra da agricultura, Kátia Abreu, P1 precisa interromper a reprodução, pois os alunos começam a fazer comentários exaltados, indignados. A fala da ministra, contida na versão do documentário "O veneno está na mesa" publicado em 2011, girava em torno da defesa do uso de agrotóxicos na produção de alimentos no Brasil, utilizando argumentos que os alunos desconstruíram no episódio 12.

Este momento oportuniza a professora a discutir com os alunos aspectos políticos relacionados ao sistema de monocultura que utiliza sementes transgênicas e agrotóxicos. O episódio 12 refere-se a este momento da aula.

Episódio 12 Aspectos políticos relacionados ao sistema de monocultura extensiva utilizado no Brasil.

\begin{tabular}{|c|l|}
\hline Turno & Interações discursivas \\
\hline 846 & Alunos: hããã!!!??? O quê!!! (alvoroço) \\
\hline 847 & $\begin{array}{l}\text { Janaína: Ela colocou assim: "pra beneficiar uma minoria", só que, se } \\
\text { você coloca agrotóxico, você não está beneficiando somente a } \\
\text { minoria, é..., dona das terras? (comentários, alvoroço) }\end{array}$ \\
\hline 848 & Nicolas: Ah, mas eles podem comprar alimento natural, né! \\
\hline 849 & P1: E assim, alguém sabe quem que é essa mulher? \\
\hline 850 & Alunos: Não \\
\hline
\end{tabular}




\begin{tabular}{|c|c|}
\hline 851 & $\begin{array}{l}\text { Paulo: Ela é alguma coisa da agricultura. E dá pra perceber como } \\
\text { argumentadora o que ela tá defendendo. Ela apresenta os argumentos } \\
\text { mascarando, dá pra ver nitidamente que ela tá tentando }\end{array}$ \\
\hline 852 & Vivian: Ela mascara o outro lado \\
\hline 853 & Paulo: Isso, ela tá apresentando \\
\hline 854 & $\begin{array}{l}\text { Janaína: Ela mascara sem vergonha, véio! "Eu nunca fiz essa conta, } \\
\text { mas deve precisar de uns } 4 \text { Brasis" (imitando a fala da ministra). Se } \\
\text { você não fez a conta, você não divulga os dados, tipo, se você não fez! } \\
\text { Porque você vai perder credibilidade, e outra, você tá jogando na } \\
\text { política, você tá ali representando essas pessoas, você tem que } \\
\text { dominar! Não fala! }\end{array}$ \\
\hline 855 & Thaís: Nossa, você não beneficia a minoria, nem a pau! \\
\hline 856 & P1: Gente, ela é a nossa ministra da agricultura \\
\hline 857 & Alunos: Aaaaaaaaaaaa! (alvoroço) \\
\hline 858 & $\begin{array}{l}\text { P1: Ela era senadora de Tocantins, mas antes disso, antes de ser } \\
\text { ministra, ela é uma grande empresária do agronegócio. }\end{array}$ \\
\hline 859 & Tami: Ah! Por isso que ela vai defender \\
\hline 861 & Thaís: Meu Deus do céu! \\
\hline 862 & Nicolas: Professora, mas o que (inaudível) \\
\hline 863 & P1: Oi? \\
\hline 864 & $\begin{array}{l}\text { Nicolas: O que fazer com esse conhecimento? Porque agora a gente } \\
\text { sabe tanta coisa. E agora? E agora? A gente fica de mãos atadas, } \\
\text { porque a gente não pode fazer mais, porque a gente vai saber que a } \\
\text { gente tá errado, porque até então, a gente errava, mas não sabia, esse } \\
\text { que é o problema }\end{array}$ \\
\hline 865 & P1: Boa! E assim, o que que é o argumento mais forte dela? \\
\hline 866 & Janaína: A minoria \\
\hline 867 & Pietro: População pobre comer \\
\hline 868 & $\begin{array}{l}\text { Thaís: A minoria. Provavelmente a minoria, sabe porquê? A gente } \\
\text { sabe que o uso de agrotóxico e das grandes plantações no Brasil só } \\
\text { favorece a...a minoria dos, dos ricos, no caso }\end{array}$ \\
\hline 869 & P1: Tem outro argumento também \\
\hline 870 & Paulo: Ela usa matemática \\
\hline 871 & Vivian: A saúde pública \\
\hline 872 & Paulo: Pode crer \\
\hline 873 & $\begin{array}{l}\text { Vivian: Ela fala que a oposição joga, falando que, usando a saúde, } \\
\text { falando que se continuar com isso, a maioria, todos brasileiros, no } \\
\text { caso, vão se prejudicar. O que é verdade }\end{array}$ \\
\hline
\end{tabular}




\begin{tabular}{|c|l|}
874 & $\begin{array}{l}\text { P1: E tem uma coisa, também, que ela fala, que é o seguinte, é, ela } \\
\text { fala assim "não tem outro jeito, pra produzir o tanto de comida que } \\
\text { precisa, e barato", né, "o povo brasileiro", o povo brasileiro é pobre, } \\
\text { "pra produzir o tanto que precisa, no preço que o povo quer, tem que } \\
\text { ser assim, não tem outro jeito" }\end{array}$ \\
\hline 875 & $\begin{array}{l}\text { Nicolas: E ela também, ela começa fazer uma controvérsia, né, tipo } \\
\text { assim, (inaudível) como diminuir os custos da, dos gastos com a } \\
\text { alimentação, pra induzir as pessoas pensar em outras coisas, que ela } \\
\text { tá a favor a (inaudível) alimentar a faixa pobre }\end{array}$ \\
\hline 876 & $\begin{array}{l}\text { P1: Aham. Então, gente, e com isso, assim, parece que a gente tá num } \\
\text { mato sem cachorro, né? }\end{array}$ \\
\hline 877 & Vivian: O Bia, você pode passar de novo? \\
\hline 878 & P1: Ela falando? \\
\hline 879 & Vivian: É. \\
\hline 880 & P1: Vamos passar \\
\hline 881 & Thaís: Não, eu tô muito de cara! \\
\hline 882 & $\begin{array}{l}\text { Rafael: Pensô, ela vira assim e fala "ah, vocês não morreram até hoje, } \\
\text { continua comendo" }\end{array}$ \\
\hline 883 & P1 Passa a fala de Kátia Abreu novamente \\
\hline 884 & $\ldots$. (reprodução do vídeo, comentários paralelos) \\
\hline 885 & P4: Prestem atenção que ela usa agrotóxico com o termo "defensivo" \\
\hline 886 & $\ldots$. (reprodução do vídeo, comentários paralelos) \\
\hline 887 & $\begin{array}{l}\text { Vivian: Parece que eles fazem isso pra ferrar com a nossa saúde. } \\
\text { Tudo favorece eles! }\end{array}$ \\
\hline 888 & Comentários e conversas \\
\hline & \\
\hline
\end{tabular}

O que mais se destaca no episódio 12 é a tomada de consciência por parte dos alunos sobre o posicionamento dos governantes, no caso, da ministra da fazenda, que defende e mantém até hoje o sistema de monocultura extensiva com uso de sementes transgênicas e agrotóxicos. Vale lembrar que no episódio 11 os alunos não demonstraram ter conhecimento sobre a influência do governo na produção dos biocombustíveis e alimentos (T. 826 e 827), o que agora torna-se percepção da realidade transformada. Sendo o aspecto sócio-político real da controvérsia sociocientífica em questão (QSC) um instrumento motivador da análise crítica dos alunos, a qual se configura como uma atividade intencional e consciente. 
Quando em 864, Nicolas expressa a questão sobre "o que fazer com esse conhecimento", no sentido de tomar o problema para si, no entanto, de uma maneira como se tomasse parte da culpa em consumir produtos vindos das monoculturas. A professora, infelizmente, não o orienta neste sentido e prossegue a aula, perdendo a chance de orientar os alunos, direcionando-os a pesquisar sobre os candidatos políticos antes de votar, dentre outras atitudes. Em 873, 882 e 887, os alunos se reconhecem como vítimas desse sistema. Dessa forma, poderia ser planejado, para esse momento, um levantamento sobre possíveis atitudes que poderíamos tomar diante do quadro apresentado até o momento.

As pretensões em apresentar possibilidades alternativas ao sistema de monocultura estavam baseadas em apresentar a produção de alimentos livres de agrotóxicos pelo Sistema de Agro Floresta (SAF) e agricultura familiar, com outros trechos do mesmo documentário. O episódio 13 mostra as perguntas dos alunos para a professora após assistirem essa sequência de vídeos e a última pergunta da professora para os alunos "O que a entalpia tem a ver com tudo isso que a gente viu?"

Episódio 13 O que a entalpia tem a ver com tudo isso que a gente viu?

\begin{tabular}{|c|c|}
\hline Turno & Interações discursivas \\
\hline 902 & Vários alunos: O Bia!/ risos/ Nossa, quem que vai falar primeiro? \\
\hline 903 & Thaís: Posso perguntar primeiro? \\
\hline 904 & Alunos: Não (risos) \\
\hline 905 & $\begin{array}{l}\text { Thaís: Então, mas, por exemplo, se eu quiser salvar uma área que já } \\
\text { foi cultivada com uso de agrotóxico, e tal, fertilização do solo, eu } \\
\text { consigo salvar esse solo ainda, se eu quiser? }\end{array}$ \\
\hline 906 & P1: Consegue \\
\hline 907 & Janaína: É bom usar leguminosa, né? \\
\hline 908 & $\begin{array}{l}\text { P1: Consegue, pode demorar um pouco, né, e..., você, precisar de um } \\
\text { tempo, assim, pro solo se recuperar, acho que, tem a sucessão } \\
\text { ecológica, né? (pergunta para P4, biólogo) Que se faz, né? De plantas } \\
\text { menores, eu não sei o P4 podia explicar melhor isso. De plantas } \\
\text { menores você vai }\end{array}$ \\
\hline
\end{tabular}




\begin{tabular}{|c|c|}
\hline 909 & $\begin{array}{l}\text { P4: É, as plantas pioneiras, né, as primeiras que você planta lá, elas } \\
\text { dão uma renovada no solo, elas vão, né, as raízes delas e as folhas } \\
\text { delas que vão caindo, vão, é, digamos assim, não bem limpando, mas } \\
\text { assim, vai formando uma outra camada por cima, de solo, onde não } \\
\text { tava dando nada. E ao longo do tempo esse agrotóxico que ficou lá vai } \\
\text { degradando }\end{array}$ \\
\hline 910 & $\begin{array}{l}\text { P1: E outra coisa, já tem em grandes cidades, assim, acho que } \\
\text { Ribeirão ainda não tem, mas já tem feira agroecológica que consegue } \\
\text { equiparar o preço do produto orgânico com o do supermercado...Aqui, } \\
\text { por exemplo, eu sei de uma feira do MST, mas eu não sei como é o } \\
\text { preço...Então, assim, tem solução, por esse outro modo de produção } \\
\text { que é a agroecologia. Então, aí tem uma perguntinha que eu queria } \\
\text { fazer pra vocês. O que que a entalpia tem a ver com isso? }\end{array}$ \\
\hline 911 & Alunos: risos \\
\hline 912 & $\begin{array}{l}\text { Maria: O Bia, mas sobre a agroecologia, naquela fazenda que a gente } \\
\text { foi no ano passado, a gente plantou várias coisas, assim, num espaço, } \\
\text { assim, bem pequeno, né? Muita coisa, feijão, que mais, May? }\end{array}$ \\
\hline 913 & $\begin{array}{l}\text { P1: É então, inclusive tem uma fazenda agroecológica que a gente } \\
\text { visitou o ano passado, se vocês quiserem ir }\end{array}$ \\
\hline 914 & Thaís: Como? \\
\hline 915 & P1: Uma fazenda agroecológica em São Joaquim da Barra... \\
\hline 916 & ... (alunos começam a perguntar sobre a fazenda agroecológica) \\
\hline 917 & $\begin{array}{l}\text { P1: Tá, mas vamos continuar a aula, peraí, gente, vocês tão fugindo } \\
\text { da minha pergunta, né (risos) }\end{array}$ \\
\hline 918 & Breno: Pergunta? (risos) Já responderam \\
\hline 919 & P1: O que que a entalpia tem a ver com tudo isso que a gente viu? \\
\hline 920 & Rafael: Vixxx, com os agrotóxico \\
\hline 921 & $\begin{array}{l}\text { P1: Não, vamo, eu vô fechar mais a pergunta, é, a gente tá vendo } \\
\text { bastante monocultura de alimento, né? O que que tem a ver entalpia, } \\
\text { monocultura de alimentos, eu, nós (silêncio) lembrando que a entalpia } \\
\text { é energia (silêncio) liberada ou absorvida }\end{array}$ \\
\hline 922 & Thaís: É a forma de crescimento mais rápido? \\
\hline 923 & P1: Do quê? \\
\hline 924 & Thaís: Dos alimentos? \\
\hline 925 & $\begin{array}{l}\text { P1: Mas ó, tá falando o tempo inteiro aqui, o vídeo tá falando de } \\
\text { alimentos. Qual que é a minha relação com o alimento? }\end{array}$ \\
\hline 926 & Tami: A energia que ele libera \\
\hline 927 & $\begin{array}{l}\text { P1: É..., Alisson pega, por favor, pra mim, aquela, aquele pacote de } \\
\text { bolacha salgada, ali, esse daí mesmo... Ó, aqui no pacote de bolacha, } \\
\text { ou, no pacote de alimento que vocês compram sempre, né, tem a } \\
\text { tabelinha nutricional. Janaína, vê pra mim que unidade é aqui, a } \\
\text { caloria, é, quer dizer, é o valor energético? }\end{array}$ \\
\hline
\end{tabular}




\begin{tabular}{|c|c|}
\hline 928 & Janaína: KJ (quilo joule). Entalpia! \\
\hline 929 & $\begin{array}{l}\text { Tami: Tem valor em caloria e em KJ na tabela nutricional. A } \\
\text { normalmente essa medida que eles colocam é com base em uma dieta } \\
\text { de duas mil Kcal (inaudível) eles colocam em percentual de calorias ou } \\
\text { quilo joules que você pode ingerir por dia, mas tem bem especificado } \\
\text { que é com base em uma dieta de tresent...duas mil quilo calorias e... } \\
\text { não sei quantos mil quilo joules, acho que é seis mil... }\end{array}$ \\
\hline 930 & Janaína: 8.400 \\
\hline 931 & $\begin{array}{l}\text { P1: E o que que tem a ver, então, entalpia, com a gente, com o } \\
\text { alimento }\end{array}$ \\
\hline 932 & $\begin{array}{l}\text { Janaína: Que quando a gente consome o alimento, o alimento va } \\
\text { fornecer energia pra gente realizar as nossas atividades metabólicas } \\
\text { enfim, }\end{array}$ \\
\hline 933 & P1: Sem alimento, o que acontece com a gente? \\
\hline 934 & Rafael: Morre \\
\hline 935 & P1: Morre \\
\hline 936 & $\begin{array}{l}\text { P1: Sem essa energia que a gente vai buscar no alim...que a gente } \\
\text { não é planta, né, a gente não fabrica o nosso próprio alimento, então a } \\
\text { gente vai buscar essa energia. E tá aqui, gente (mostra o pacote de } \\
\text { bolacha), a gente pode calcular essa energia. Tanto que muitas } \\
\text { meninas, principalmente, mas meninos também, né, fica sempre } \\
\text { controlando, ah isso aqui tem tantas calorias. O que que é esse "tantas } \\
\text { calorias"? }\end{array}$ \\
\hline 937 & Maria: Energia \\
\hline 938 & Janaína: Quanto de energia a gente tá comendo. \\
\hline 939 & $\begin{array}{l}\text { P1: A energia liberada na metabolização do alimento no nosso } \\
\text { organismo. Se a gente, por exemplo, pensar o seguinte, é, fala aí, por } \\
\text { exemplo, uma molécula que tá sempre no alimento e a gente sempre } \\
\text { come, e a gente sempre precisa? }\end{array}$ \\
\hline 940 & Paulo: Glicose \\
\hline 941 & Maria: Carboidrato \\
\hline 942 & $\begin{array}{l}\text { P1: Isso (vai até a lousa). Por exemplo, né, a glicose (escreve a } \\
\text { fórmula molecular na lousa). H12 O6. A glicose, na verdade, assim, né } \\
\text { no processo de digestão a gente come amido, né, que é um polímero } \\
\text { da glicose, então o amido vai sendo quebrado, quando chega no } \\
\text { sangue, quando chega na célula, é glicose que entra lá. Aí esse } \\
\text { processo aqui, ó (começa a escrever a reação de respiração celular na } \\
\text { lousa), a glicose mais o oxigênio que a gente respira, produz } \mathrm{CO}_{2} \\
\text { água }\end{array}$ \\
\hline 943 & Janaína: Meu Jesus! É combustão? (risos) Dentro da gente? \\
\hline 944 & $\begin{array}{l}\text { P1: É combustão (risos) dentro da gente! Isso aqui (aponta para a a } \\
\text { formula molecular da glicose) é o combustível, a gente pode falar que }\end{array}$ \\
\hline
\end{tabular}




\begin{tabular}{|c|c|}
\hline & a glicose é o nosso combustível, não pode? \\
\hline 945 & Janaína: Que maaaassa! (risos) \\
\hline 946 & $\begin{array}{l}\text { P1: E isso aqui também vai ter...vocês acham que vai ter uma variação } \\
\text { de entalpia, é..., negativa ou positiva? Vai liberar ou vai }\end{array}$ \\
\hline 947 & Nicolas: É por isso que as vezes \\
\hline 948 & Janaína: Negativa, que libera energia pra gente usar \\
\hline 949 & $\begin{array}{l}\text { P1: Vai liberar energia pra gente. Pra gente usar, transformar em } \\
\text { trabalho, por exemplo, né, então, sem essa reaçãozinha aqui, a gente } \\
\text { depende dessa reaçãozinha aqui de respiração celular, na verdade, } \\
\text { dentro da gente, funcionando, a todo momento, né. Viu como entalpia } \\
\text { é importante? }\end{array}$ \\
\hline 950 & Alunos: Éhh... \\
\hline 951 & Janaína: Maaassa... \\
\hline 952 & P1: Então vocês entenderam mais ou menos isso aqui? \\
\hline 953 & Maria: Uhum \\
\hline 954 & $\begin{array}{l}\text { P1: O alimento...e isso acontece dentro, dentro da célula, tá? Então a } \\
\text { gente pode pensar na entalpia voltando pra dentro da gente também. } \\
\text { E isso vem do alimento, o alimento, vem desse processo produtivo, } \\
\text { que é monocultura, que é o mesmo processo produtivo dos } \\
\text { combustíveis, né, os combustíveis, biocombustíveis, eles são } \\
\text { combustíveis pra máquinas, pra carros e outras máquinas, a glicose é } \\
\text { combustível pra gente, e nisso tudo tem troca de energia }\end{array}$ \\
\hline
\end{tabular}

5.1.7.1 Generalização, concretização, apropriação (episódio 13: 0 que a entalpia tem a ver com tudo isso que a gente viu?)

Em relação à interação dos alunos com os conceitos da termoquímica, esta interação compõe uma atividade que requer uma generalização do conceito de entalpia de modo que o mesmo transite entre o sistema conceitual dos combustíveis para o sistema conceitual dos alimentos, de forma que contribua para o desenvolvimento/formação do conceito de entalpia no aluno, baseando-nos em Vigotski (2009) ao dizer que parte da essência do desenvolvimento do conceito consiste na sua transição de uma estrutura de generalização à outra, sendo o conceito expresso por uma palavra a representação de uma generalização 
Trata-se da necessidade de aplicação do princípio geral do conceito de entalpia, e, de combustão, em novo contexto, para além de seu sistema conceitual científico, abstrato, para além de sua generalização ao sistema conceitual particular da produção e uso dos combustíveis, cujo sujeito é o aluno como consumidor, generalizando-o para o sistema conceitual da produção de alimentos, cujo sujeito continue sendo o aluno como consumidor. Esta atividade busca se aproximar do que Davídov (1988) propõem em relação ao aluno apreender o princípio geral do conceito, desde sua manifestação abstrata até sua manifestação concreta, de modo que o aluno perceba como o aspecto geral do conceito também aparece em cada caso particular.

A necessidade da generalização do conceito de entalpia entre o sistema conceitual dos combustíveis para o sistema conceitual dos alimentos é colocada pela professora desde T. 910 "O que a entalpia tem a ver com isso?", cuja apropriação pelos alunos não é imediata, mas mediada por perguntas cada vez mais focadas no consumo de alimentos (T. 925 e 931) e pela tabela nutricional de um pacote de bolachas.

O movimento da atividade deste episódio em relação à interação dos alunos com conceitos da termoquímica configura uma relação constante entre concreto e abstrato. Parte-se da atividade de crítica socioambiental ao sistema de monocultura extensiva da produção de biocombustíveis, iniciada no episódio 11 e complementada pelo documentário, o qual faz a mesma crítica no contexto histórico-social da produção de alimentos no Brasil. Este contexto histórico-social configura o ponto de partida concreto, o qual já não é apenas sensório e aparente, mas sistematizado e significado pelas atividades anteriores. Em T. 925 propõem-se a pergunta "Qual é a minha relação com o alimento?" de modo que a resposta de Tami reproduz uma generalização em $\mathrm{T}$. 926 "A energia que ele libera". Esta generalização coincide com o significado da interação da energia do alimento com nosso organismo, reproduzindo uma forma de ação do conceito abstrato de energia, estabelecendo um movimento de aproximação da pergunta que parte do concreto à resposta que emerge do abstrato. 
Em T. 927, a mediação concreta, cujo instrumento é a tabela nutricional de um pacote de bolachas, leva Janaína a uma generalização/tomada de consciência em T. 928, em relação ao conceito de energia fornecida pelo alimento, em um movimento do concreto ao abstrato, já que, a partir das informações da tabela nutricional em mãos, reconhece a energia expressa pela unidade Kilo Joule (KJ).

Em T. 931 e 932 a entalpia (abstrato) é relacionada ao alimento e aos sujeitos (concreto), de modo a resultar em uma unidade entre concreto e abstrato na resposta da aluna T. 932 “...quando a gente consome o alimento, $o$ alimento vai fornecer energia para gente realizar as nossas atividades metabólicas, enfim,", o que também se configura como uma generalização que coincide com os significados dos conceitos envolvidos.

Em T. 936 "O que que é esse "tantas calorias?", referindo-se à informação da tabela nutricional do pacote de bolachas, é respondido por Maria em T. 937 com nova generalização/significação no abstrato "Energia".

A partir de T. 939 a professora se utiliza da reação de respiração celular com instrumento mediador para a generalização das formas de ação dos conceitos de combustão e entalpia, a partir do abstrato. Ou seja, um movimento constante entre o abstrato e o concreto. Neste movimento também reside o movimento de concretização e sistematização. Os conceitos espontâneos mais utilizados foram: alimento, nosso organismo, tabela nutricional. Os principais conceitos científicos são a entalpia e a reação de combustão. Como já dito nas análises anteriores, os primeiros proporcionando concretude aos segundos e os segundos proporcionando sistematização aos primeiros. Gostaríamos de destacar que este movimento é importante para a busca de respostas ao nosso problema de pesquisa, pois o que se aprende dentro da escola precisa servir à vida do aluno fora da escola. 


\subsubsection{Generalização, significação, apropriação (episódio 13: 0 que a entalpia tem a ver com tudo isso que a gente viu?)}

Consideramos que neste episódio, como já ocorreu em episódios anteriores, a generalização é acompanhada de significação, constituindo também as apropriações. Percebemos que a coincidência entre generalização e significação se intensifica ao longo da sequência de atividades, e atribuímos isto ao fato de que o concreto, a realidade concreta do aluno já reproduz maior nível de sistematização se comparada ao início da atividade. No início, os alunos tinham dificuldades e limitações nas generalizações com os conceitos de entalpia e combustão. As mediações da professora eram mais longas. Agora, percebemos que as generalizações, mesmo que sejam para além do sistema conceitual científico dos conceitos da termoquímica, coincidem mais com o significado dos conceitos e ocorrem com mediações mais reduzidas. Isso pode ser observado no episódio 13 a partir de T. 925, pois a partir deste turno, as generalizações dos alunos coincidem com 0 significado dos conceitos.

Podemos destacar dois movimentos de generalização dos conceitos da termoquímica. O primeiro, mediado com os dados da tabela nutricional do pacote de bolachas, mais precisamente a unidade de medida Kilo Joule (KJ), quando Janaína, em T. 928 generaliza o conceito de entalpia por meio da unidade de medida KJ. Esta generalização parte dos sistemas conceituais dos combustíveis, estudados anteriormente, e chega até conceito espontâneo/cotidiano de alimento. Generalização que se caracteriza como tomada de consciência da relação do conceito de entalpia com os alimentos. $O$ prosseguimento do diálogo leva a T. 932: generalização que coincide com o significado do conceito, cuja significação reproduz uma forma de ação do objeto entalpia em um caso particular, como energia fornecida pelo alimento. Segundo Leontiev (1983), por trás das significações idiomáticas se escondem as formas de ação - operações - socialmente elaboradas, em cujo processo as pessoas transformam e conhecem a realidade objetiva. Assim, consideramos que em T. 932 a aluna opera com o conceito de energia relacionado ao alimento, de forma a conhecer mais e transformar sua percepção sobre a realidade. 
O segundo movimento é mediado pelo sistema conceitual científico da reação de respiração celular $\left(\mathrm{C}_{6} \mathrm{H}_{12} \mathrm{O}_{6(\mathrm{~g})}+6 \mathrm{O}_{2(\mathrm{~g})} \rightarrow 6 \mathrm{H}_{2} \mathrm{O}_{(\mathrm{g})}+6 \mathrm{CO}_{2(\mathrm{~g})}\right)$, que além de instrumento é um novo caso particular (DAVÍDOV, 1988) para a aplicação do conceito de entalpia e também para o conceito de combustão.

Quando a professora escreve a representação da reação de respiração celular na lousa, o faz por meio de uma narrativa contendo conceitos do conhecimento escolar familiares para estes alunos em T. 942 “...A glicose, na verdade, assim, né, no processo de digestão a gente come amido, né, que é um polímero da glicose, então o amido vai sendo quebrado, quando chega no sangue, quando chega na célula, é glicose que entra lá. Aí esse processo aqui, ó (começa a escrever a reação de respiração celular na lousa), a glicose mais o oxigênio que a gente respira, produz $\mathrm{CO}_{2(g)}$ e água", o que contribui para a localização do sistema conceitual reação de respiração celular no sistema de conhecimento dos alunos. Vale salientar que até o momento, neste segundo dia de aula, a professora não mencionou o termo combustão. A partir da reação escrita na lousa, Janaína generaliza o conceito de combustão, tomando consciência de sua forma geral (DAVÍDOV, 1988) presente na reação de respiração celular e no corpo humano, em T. 943 "Meu Jesus! É combustão? (risos) dentro da gente?". Esta generalização, necessariamente, requer o reconhecimento da representação do princípio geral do conceito de combustão: a interação entre o combustível, o comburente oxigênio e a presença de água e gás carbônico nos produtos, o que proporciona o desenvolvimento do conceito de combustão, e do conceito de combustível. A combustão não mais relacionada apenas aos combustíveis dos veículos, mas dentro do nosso organismo, e o alimento como combustível. Em T. 948, por meio da pergunta da professora T. 946 “...vocês acham que vai ter uma variação de entalpia negativa ou positiva? Vai liberar ou vai”, a aluna traz também o conceito de entalpia para o sistema conceitual da reação de respiração celular do nosso organismo, generalizando uma forma de ação do conceito de entalpia neste novo caso particular, na seguinte operação com o conceito: "Negativa, que libera energia pra gente usar" (T. 948). Assim o desenvolvimento do conceito de entalpia prossegue para a aluna, bem como sua percepção sobre a realidade objetiva. 


\subsection{Análise dos textos produzidos pelos alunos}

Retomamos que, dentro da atividade de escolha de um carro, os alunos produziram um texto, no qual eles são convidados a justificar a escolha de um carro em função do combustível a ser utilizado, por meio de elementos do tema discutido em aula "Produção e uso de combustíveis pelo homem".

Já é esperado que o conceito de entalpia não seja reproduzido no texto, primeiro porque sabemos que o fator econômico terá maior peso na decisão dos alunos, sendo o primeiro critério levantado por eles para a compra de um carro, e no momento da atividade o instrumento definitivo na determinação do preço dos combustíveis foram os valores de rendimento do motor, de modo que a entalpia estava mais relacionada à compreensão da origem da energia dos combustíveis e indiretamente relacionada ao preço. Segundo porque a questão do texto não evoca o caso dos alimentos para o qual a entalpia foi generalizada.

Como a justificativa da escolha do carro deve ser em função dos combustíveis, esperamos observar como se deu a sistematização do conceito de combustível pela atividade em relação à tomada de consciência das controvérsias sociocientíficas e relações CTSA com as quais estão envolvidos.

No início da análise dos indícios de formação de conceitos nos episódios, consideramos o conceito de combustível como um conceito espontâneo, operado pelo aluno em seu cotidiano com um certo grau de sistematização correspondente ao contexto histórico-cultural. Conforme transcorreu a atividade, o conceito espontâneo estabeleceu generalizações com formas de ação do conceito determinadas pelo sistema conceitual científico, como sua forma representacional na linguagem simbólica (fórmula molecular) e escrita (nomenclatura) da química, sua função dentro da reação de combustão, seu potencial energético, sua emissão de $\mathrm{CO}_{2(\mathrm{~g})}$ e com aspectos socioambientais de sua produção sob a monocultura extensiva. Esta sistematização proporciona, aos poucos, a transformação da percepção da realidade objetiva, refletindo características, nexos e relações do conceito no mundo objetal. É este reflexo no mundo objetal, transformado por esta sistematização, refletido nas relações CTSA (sociais, ambientais, tecnológicas, 
políticas e econômicas) para a escolha do carro, produzidas pela crítica ao uso e produção dos combustíveis, o principal foco de análise dos textos.

Entretanto, sabemos que o ato da escrita, de acordo com Vigotski (2009), como uma função específica da linguagem, difere da fala pela estrutura e pelo modo de funcionamento, sendo uma linguagem desprovida de som, de expressões entonacionais, que não se utiliza de palavras, mas das representações das mesmas. Difere da linguagem falada assim como o pensamento teórico difere do pensamento concreto. Sendo natural que a linguagem escrita não corresponda ao nível de desenvolvimento da linguagem falada.

A partir destas considerações, seguimos com a análise dos textos produzidos. As cópias dos textos originais se encontram no apêndice $B$, numerados de 1 a 14. Os nomes dos alunos foram retirados para preservação da identidade. Dividiremos a análise em duas etapas. Primeiramente analisaremos a opção de carro apresentada pelos alunos em função de sua justificativa determinante. A segunda parte analisa a apropriação e sistematização de conceitos da termoquímica em meio às relações CTSA.

Justificativa determinante para a escolha do carro

A leitura dos textos nos mostrou que 13 dos alunos optaram pelo carro flex, baseando-se na justificativa econômica. 1 (texto 5) não fez a opção pelo carro, mas pelo combustível.

Dos 13 alunos que optaram pelo carro flex, baseando-se na justificativa econômica, 12 se apropriaram de formas de ação da relação entre rendimento do motor e preço, sintetizadas e refletidas no contexto socioeconômico, como mostrado nos seguintes trechos:

"Flex. Atualmente escolheria o combustível álcool, pois está mais barato e segundo as contas de rendimento está compensando até o valor de $R \$$ 
2,25...Mas por que Flex então? O álcool pode sofrer alterações econômicas bem como a gasolina, sendo mais ou menos viável" (texto 2)

"Eu escolheria o carro 1.0 Flex...Na situação do preço do álcool ultrapassar a marca de $69 \%$ do preço da gasolina, esta passa a ser economicamente mais interessante. E nesse momento que o carro flex passa a ser interessante também" (texto 3)

Em alguns textos, esta apropriação (formas de ação da relação entre rendimento do motor e preço) é reproduzida de forma mais reduzida em relação aos exemplos anteriores, de modo a reproduzir as características, nexos e relações do mundo objetal:

"Eu optaria por um automóvel Flex pois com ele conseguiria fazer um rodízio e utilizar os dois tipos de combustível, pensando na economia financeira e desempenho do carro" (texto 4)

Nestes trechos, não são reproduzidas as formas de ação da relação entre o rendimento do motor e do preço, mas significações que guardam as formas de ação. Segundo Leontiev (1983), por trás das significações estão as formas de ação (operações) em cujo processo as pessoas conhecem e transformam a realidade objetiva.

Somente 1 texto foi escrito apenas em função do argumento econômico (texto 6). Todos os demais, apesar de fazerem a opção final em função da economia, levantaram prós e contras da atividade de crítica socioambiental relacionada aos combustíveis. A reprodução desta atividade foi manifestada desde formas muito reduzidas, trazendo apenas um dos aspectos socioambientais discutidos, como no texto 7 , até formas que trazem uma síntese de todos os pontos discutidos em aula, como no texto 8 , o que reflete na menor ou maior sistematização do conceito de combustível refletida no contexto histórico-social do aluno.

Apropriação dos conceitos da termoquímica em meio as relações CTSA

Os conceitos da termoquímica reproduzidos nos textos foram o conceito de combustível (álcool, gasolina, biodiesel) e combustão. O conceito de 
combustível, como esperado, foi reproduzido em todos os textos, enquanto que o conceito de combustão aparece em 1 texto, expresso da seguinte maneira:

"A gasolina tem maior poder de combustão comparado com o gás natural e o álcool” (texto 1).

Trata-se de uma apropriação que guarda em si uma das formas de ação do conceito, a qual expressa, em outras palavras a liberação de energia pela gasolina. Esta apropriação se encontra em meio a um levantamento de prós e contras entre gasolina e álcool, utilizado no texto como instrumento desta discussão. O "maior poder de combustão" da gasolina, sua maior liberação de energia, sendo a parte derivada dos conceitos científicos relacionada, nesta frase, aos outros combustíveis e, dentro do texto, a fatores econômicos e ambientais:

"Porém o álcool acaba sendo mais vantajoso por ter um valor reduzido e também por poluir bem menos que o gás e a gasolina, mas por outro lado proporciona um enorme impacto ambiental destrói a biodiversidade, polui rios e terra e até o ar com o uso de agrotóxicos nas plantações" (texto 1)

Os aspectos sociais não estão presentes neste texto, sendo que a apropriação de formas de ação da crítica ambiental proporcionada pela QSC sobre o uso de agrotóxicos e relacionada a produção de biocombustíveis é reproduzida sem os aspectos sociais relacionados à exploração dos trabalhadores do campo. $O$ aspecto social presente é apenas o econômico, relacionado a vida individual do aluno. Isto nos leva a pensar que não basta incluir o aluno, ativamente, como sujeito histórico-social da atividade. É preciso uma atividade que enfatize o desenvolvimento de consciência social.

O conceito de combustível, uma tecnologia produzida historicamente pelo homem, é apropriado nos textos dos alunos de maneira a reproduzirem em si mesmos as formas histórico-sociais da atividade de crítica socioembiental da produção e uso do álcool, gasolina e biodiesel. Principalmente dos dois primeiros, pois são as principais opções de escolha no mercado.

Um movimento comum em todos os textos que reproduziram essa atividade de crítica é uma comparação de prós e contras de características desses combustíveis, relacionadas às formas de ação da atividade de crítica 
socioambiental trabalhadas a partir da segunda ação da sequência de atividades $^{31}$ - a atividade de verificação da emissão de $\mathrm{CO}_{2(\mathrm{~g})}$ pelos combustíveis, as quais demonstram a apropriação da atividade e tomada de consciência dos impactos ambientais e sociais por meio do uso das objetivações das ações da atividade anterior na atividade de produção textual. Assim, não são os cálculos, as reações e balanceamentos, mas os resultados das verificações e comparações os quais foram reproduzidos nos textos para justificar a escolha. Neste movimento, as relações dos combustíveis com os aspectos ambientais, sociais, políticos, tecnológicos foram estabelecidas, nos limites da atividade e dentro da limitação da escrita dos alunos. Alguns exemplos das variações dessas apropriações são transcritos abaixo.

O texto 8 traz uma tabela que sintetiza e relaciona as objetivações da maioria das etapas da sequência de atividades para cada combustível. Desde os valores de entalpia, até a forma de produção. A partir desta tabela a aluna escreve:

"De todos os combustíveis discutidos em aula, se fosse possível optar uma outra forma de combustível, algo tão "puro quanto a água", algo que não devastasse tanto o meio ambiente, nenhum desses combustíveis seria escolhido, mas como é necessário escolher...se for analisado a emissão de $\mathrm{CO}_{2}$ na atimosfera a partir da Revolução Industrial com a utilização dos combustíveis fósseis o etanol é a melhor saída. Entretanto se analisarmos minuciosamente as desvantagens da monocultura é devastadora, pois é necessários grandes terrenos e vários hequitares de floresta são desimados...Além disso é utilizado vários agrotóxicos para o combate de pragas sendo esses compostos químicos o mesmo usados em armas de guerra (armas químicas). Esses agrotóxicos prejudicam a saúde das pessoas que as aplicam...As plantas também transportam esses agrotóxicos até a mesa de milhares de pessoas, e essas, por sua vez, podem sofrer consequências já que seus efeitos são bioacumulativos. Então se for observado o menos prejudicial a vida humana são os combustíveis fósseis..."

O texto 8 foi o único que defendeu o combustível fóssil como menos prejudicial, apesar de também ter optado por carro Flex devido ao fator econômico. A síntese da aluna mostra a reprodução, em si mesma, das formas histórico-sociais da atividade de crítica socioambiental sobre a produção e uso dos combustíveis em um movimento de avaliação das objetivações das

\footnotetext{
${ }^{31}$ A sequência de atividades proposta na aula é a atividade de escolha de um carro, que por sua vez, é a atividade de crítica socioambiental da produção e uso dos combustíveis pelo homem.
} 
atividades que compõem a SAt. Podemos reconhecer nas características, nexos e relações entre o conceito de combustível e o contexto histórico-social do mundo objetal todos os aspectos CTSA, inclusive o reflexo da relação da tecnologia das armas químicas e da tecnologia dos agrotóxicos, vista no documentário. A QSC sobre o uso de agrotóxicos é apropriada em meio a essas relações, nas quais generaliza o sistema de monocultura para além da produção do álcool, na produção de alimentos, por meio dos agrotóxicos, apresentando aspectos sociais da exploração do trabalhador do campo e dos riscos que correm os consumidores de alimentos. Esta reprodução das formas da atividade de crítica mostra que cada atividade não teve um fim em si mesma, mas proporcionou tomada de consciência dos problemas sociocientíficos de sua época e o desenvolvimento crítico na aluna.

No outro extremo dos textos que se apropriaram de aspectos socioambientais está o texto 7 , transcrito por completo.

"Eu escolheria um carro Flex, por causa da pouca diferença em $\mathrm{Km} / \mathrm{L}$, na variedade de preço custo a rendimento de $70 \%$, mesmo tendo como preferência o álcool por ser renovável e liberar menos $\mathrm{CO}_{2}$. Mesmo tendo ambas as opções, mesmo sabendo que a gasolina é não renovável, compensa em certas ocasiões."

No texto 7 os combustíveis são sistematizados em relação ao custo, rendimento, emissão de $\mathrm{CO}_{2(\mathrm{~g})}$ e renovabilidade, com uma forma de sistematização reduzida, sem a reprodução da QSC e com dificuldades na concordância textual.

Em todos os 13 textos que se apropriaram de aspectos socioambientais os combustíveis são sistematizados em relação ao custo, rendimento, emissão de $\mathrm{CO}_{2(\mathrm{~g})}$ e renovabilidade, no entanto com sistematizações CTSA mais desenvolvidas em relação à anterior, sendo que 3 deles sistematizaram as relações CTSA supracitadas (incluindo o texto 7). Em 4 textos a sistematização incluiu, além desses primeiros aspectos, a crítica à monocultura, sem mencionar a QSC sobre o uso de agrotóxicos, dos quais 1 inclui aspectos sociais além dos ambientais. 6 textos incluem, além dos aspectos anteriores, a QSC, dos quais 1 inclui apenas aspectos ambientais e 5 incluem também os aspectos sociais (incluindo o texto 8). Ou seja, dos 14 textos analisados: 
- 6 incluem a QSC, dos quais,

5 incluem todas as relações CTSA (textos 2, 5, 8, 9,10);

1 inclui apenas aspectos econômicos e ambientais (texto 1);

- 4 incluem crítica à monocultura, sem a QSC, dos quais,

1 inclui todas as relações CTSA (texto 12);

3 incluem apenas aspectos econômicos e ambientais (textos 11, $13,14)$;

- 3 incluem somente aspectos econômicos, emissão de $\mathrm{CO}_{2(\mathrm{~g})} \mathrm{e}$ renovabilidade (textos $3,4,7$ );

- 1 inclui apenas o aspecto econômico (texto 6).

A complexidade da sistematização dos textos contidos nestes itens cresce de baixo para cima, sendo o texto 6 o que apresenta a sistematização entre o conceito de combustível e o contexto histórico-social mais reduzida, e os textos 2, 5, 8, 9, 10 os que apresentam sistematizações mais complexas, no sentido de reproduzirem todas as relações CTSA (relações entre aspectos da ciência, tecnologia, sociedade e ambiente), incluindo a QSC sobre o uso de agrotóxicos. Excetuando os textos 1 e 12, pois o texto 12 é por nós considerado com maior sistematização do que o texto 1 , devido ao texto 12 possuir relações entre a produção do álcool e os aspectos sociais da exploração dos trabalhadores do campo. Sistematização ausente no texto 1. No entanto, por uma questão de organização, manteremos esta configuração.

Este resultado é animador, pois a maioria dos textos guarda, pelo menos, a sistematização do conceito de combustível com o aspecto econômico e aspectos ambientais. 13 dos 14 textos. Relações com aspectos sociais concernentes à exploração dos trabalhadores do campo foram mais difíceis de atingir. 6 textos.

Segundo Santos e Schnetzler (2010), uma das maiores críticas a práticas do ensino CTS era não condizer com sua proposta de abordagem das 
implicações da ciência e tecnologia na sociedade. Os aspectos sociais eram geralmente deixados de lado, corroborando para a exaltação da ciência e tecnologia ao invés de uma análise crítica dos reais impactos sobre a sociedade.

Devemos considerar que as ações da atividade de escolha de um carro (atividade de crítica socioambiental da produção e uso de combustíveis pelo homem) propunham maior número e maior sistematização de ações que se relacionavam com questões ambientais, o que se reflete no texto. $E$ a questão econômica, unânime em todos os textos, além de pertencer ao contexto histórico-social do aluno, é pessoal. Este trecho do texto 13 é um bom exemplo do caráter pessoal da escolha:

"Mas como se é preciso de um dos dois combustíveis citados para o carro andar, eu optaria pelo carro Flex, porque pra mim, no final, infelizmente, o que vai contar mesmo, o preço dos dois combustíveis para o meu bolso"

Portanto, pensar quais aspectos da realidade histórico-social do aluno queremos sistematizar junto aos conceitos científicos escolares, como os aspectos sociais, implica em incluí-los na atividade de maneira a explorar motivos, ações e operações que relacionem de forma ativa especificamente os conceitos científicos escolares e os aspectos sociais, sendo o conceito científico o objeto de estudo ligado a uma necessidade da situação social da qual queremos que o aluno tome consciência, sistematize. Acreditamos que estamos no caminho. 


\section{Considerações finais}

Diante da atual conjuntura em que nos encontramos perante as propostas de abordagem para a educação em ciências, ainda nos deparamos com o problema da ruptura entre o ensino de conceitos científicos escolares e o contexto histórico-social dos alunos. Algumas abordagens da educação em ciências sinalizam esta ruptura e a necessidade de se trazer problemas reais para serem discutidos em sala de aula, como a abordagem CTS/CTSA, sendo uma das propostas o uso das QSC.

Não pretendíamos, aqui, criticar estas propostas de modo a invalidá-las, mas de modo a compartilhar preocupações que elas mesmo colocam e buscam superar.

Além das críticas advindas das propostas da educação científica, temos também em Paulo Freire e no movimento da Educação Popular, a crítica à forma como se encontra a estrutura e o ideal de educação de um modo geral, a qual ainda está fadada a um sistema com poucas condições de oportunizar a inclusão do sujeito em um processo de ensino-aprendizagem que o torne sujeito ativo e produtivo de sua história, de maneira crítica, consciente e justa.

Acreditamos que, na educação em ciências, a aprendizagem de conceitos em meio a temas reais necessita ser organizada dentro de uma atividade de práxis, como já apontam as propostas. Mas como fazer isso? Como organizar uma aula de química que proporcione a formação de conceitos científicos escolares de forma produtiva, que resulte no desenvolvimento cognitivo em meio a tomada de consciência sobre sua realidade históricosocial? Como se dá a formação dos conceitos científicos escolares em meio a esta atividade?

Encontramos, na Teoria Histórico-Cultural, as bases teóricometodológicas para, neste trabalho, iniciar um caminho de busca pelo desenvolvimento de um processo de ensino-aprendizagem que contribua para a formação conceitos, unida à tomada de consciência do aluno sobre sua própria realidade. 
A partir da Teoria Histórico-Cultural, a Teoria da Atividade nos deu a base teórica para o modo de organização dessa atividade de práxis. E o estudo sobre a formação dos conceitos, iniciado por L. S. Vigotski e complementado por A. N. Leontiev, nos deu a base teórica para compreender o modo geral de como os conceitos se formam psicologicamente e, a partir desta base, analisar indícios de formação dos conceitos da termoquímica trabalhados nesta pesquisa em meio ao contexto histórico-social do aluno.

A organização da atividade de aprendizagem nos possibilitou utilizar as QSC e as relações CTSA como instrumentos temáticos da Educação em Ciências para a tomada de consciência e mudança de percepção do aluno sobre sua realidade social no processo de ensino aprendizagem. As relações CTSA e a QSC sobre o uso de transgênicos e agrotóxicos, organizadas pela sequência de atividades (SAt) contribuíram para a apropriação do conceito de combustível em meio ao contexto histórico-social do aluno, relacionando-o a aspectos econômicos, ambientais, sociais, tecnológicos e políticos manifestados nas falas e textos dos alunos.

As relações CTSA não são exclusivamente dependentes das QSC, podendo ser promovidas por aspectos econômicos e socioambientais (sociais, do contexto histórico-social do aluno), gerando a necessidade do estudo do conceito químico e, posteriormente, a reapropriação do conceito no contexto histórico-social, de maneira que ambos, conceito químico e contexto históricosocial estão complexificados. As QSC promovem relações CTSA mais específicas ao tema que pertencem; no entanto, intensificam e ampliam as relações CTSA e a percepção crítica do aluno, o que é evidenciado na produção textual analisada.

Os aspectos econômico e ambiental da realidade do aluno contribuíram mais diretamente para o desenvolvimento dos conceitos de entalpia, combustão e balanceamento da reação, o que pôde ser observado na análise das interações discursivas, já que os conceitos de entalpia, combustão e balanceamento de equação estiveram relacionados a aspectos econômicos e ambientais da SAt proposta ao longo da aula. 
Assim, se a necessidade da atividade tiver origem em aspectos do contexto social do aluno (quanto mais pessoal, melhor), e for unida ao conceito químico como objeto de estudo, gerará o motivo da ação de apropriação desse objeto pelo aluno, o que contribui para união entre conceito químico e contexto histórico-social. Gerar a necessidade e uní-la ao objeto de estudo torna-se papel fundamental da mediação da atividade pelo professor, que deve se apropriar deste processo desde o início do planejamento da atividade de ensino.

Dessa forma, representando o funcionamento da atividade de estudo, de acordo com o referencial teórico adotado, temos que, se a necessidade coincide com o objeto de estudo, gera o motivo da ação. Como mostrado na figura 5 .

Figura 5: atividade de estudo - a necessidade unida ao objeto de estudo gera o motivo da ação.

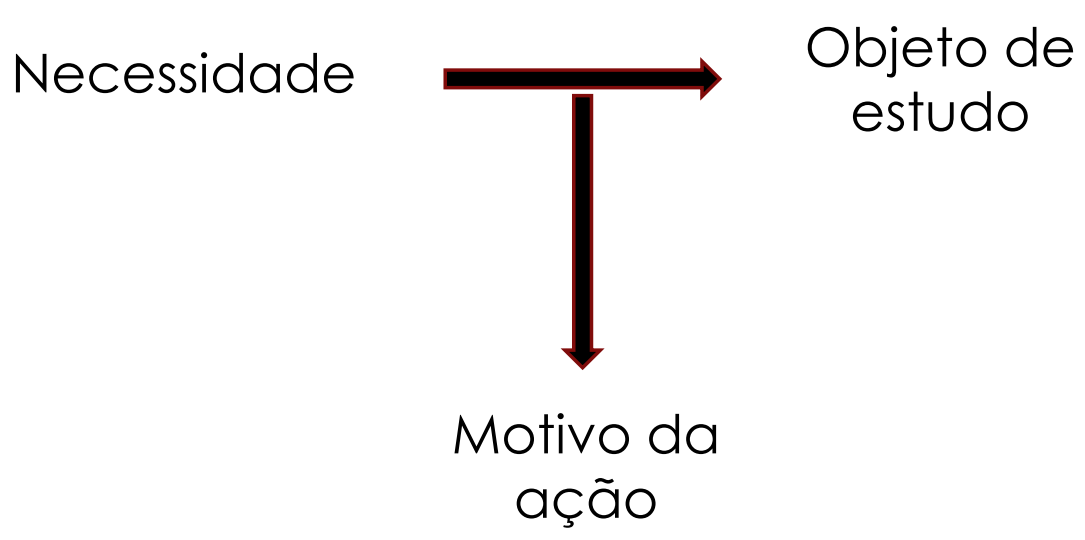

Fonte: Schneider-Felicio (2018)

Nessa atividade, a formação dos conceitos se dá no processo de objetivação da necessidade (LEONTIEV, 1983; VIGOTSKI, 2009). No nosso caso, quando a necessidade tem origem social e está voltada para a apropriação do conceito químico, podemos também representar a relação entre o abstrato e o concreto dentro do processo de objetivação da necessidade. $O$ abstrato pode ser associado ao conceito científico/químico a ser apropriado pelo aluno, e o concreto, associado ao contexto histórico-social da atividade de estudo, como mostra a figura 6 . 
Figura 6: presença da necessidade ligada ao objeto, do concreto como contexto histórico-social e do abstrato como conceito científico, na atividade de estudo.

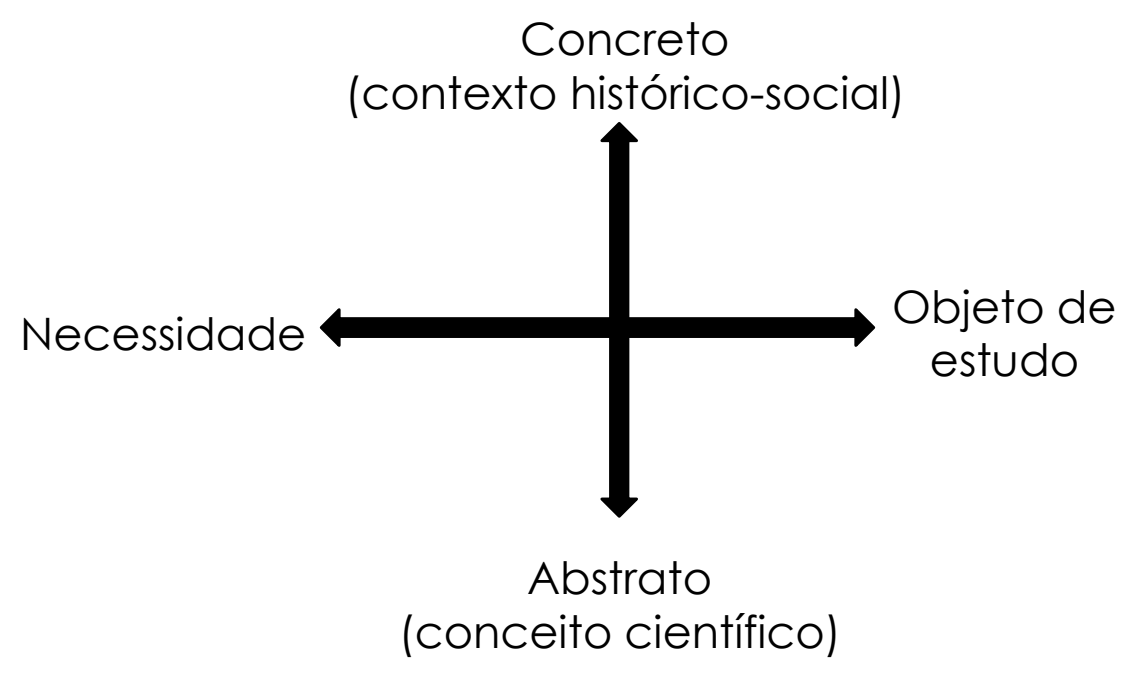

Fonte: Schneider-Felicio (2018).

Apartir da figura 6, é preciso fazer com que a necessidade da atividade de estudo parta do contexto histórico-social do aluno, tornando-se uma necessidade concreta e com que o conceito científico seja o objeto de estudo, como se rotacionássemos o eixo vertical em sentido anti-horário, como mostra a figura 7, gerando uma necessidade concreta coincidente com o objeto de estudo abstrato. 
Figura 7: coincidência entre necessidade concreta e objeto de estudo abstrato.

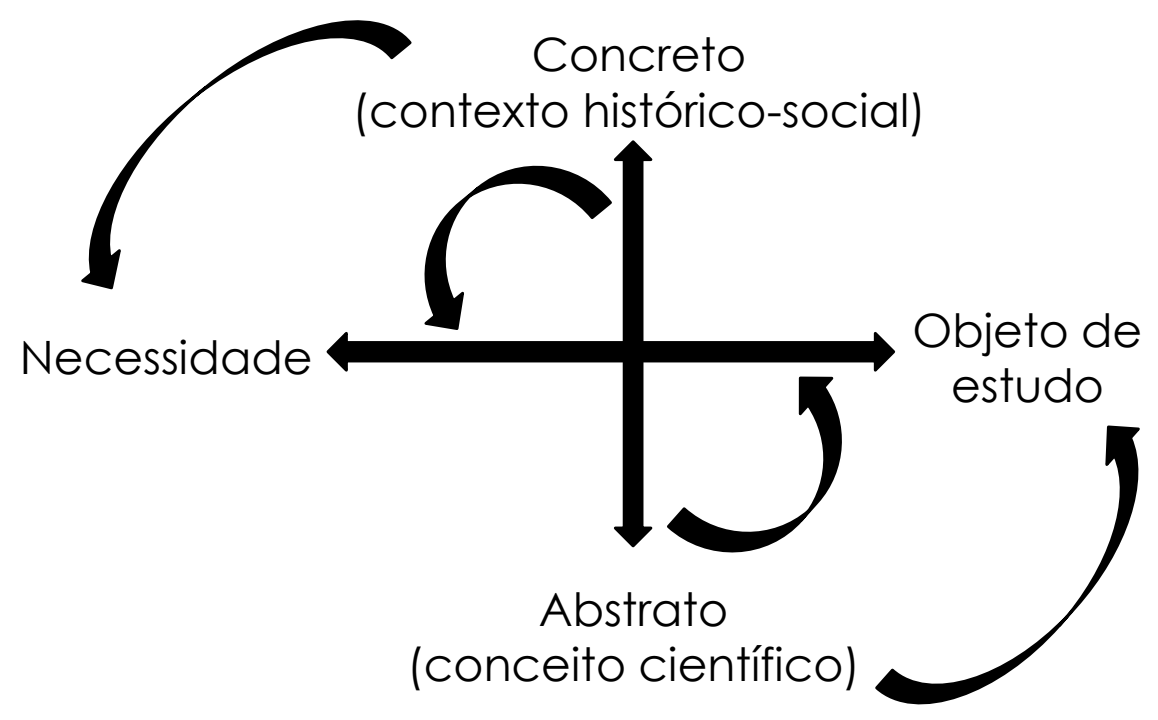

Fonte: Schneider-Felicio (2018).

Esta foi uma proposta de representação das relações já existentes na literatura referente à Teoria da Atividade Histórico-Cultural, entre necessidade, objeto, abstrato e concreto, para a atividade de estudo, do modo como entendemos que devem interagir, para que o processo da figura 5 (o surgimento da ação motivada pela necessidade) aconteça a favor da busca pela superação de um ensino tradicional acrítico que promove a ruptura entre 0 que se aprende na escola e a vida do aluno, a favor da promoção de um processo de formação de conceitos por tomada de consciência sobre seu contexto histórico-social, o que, na educação em ciências, pode contar com temas de análise crítica sobre relações CTSA e QSC, dentre outras propostas.

O movimento do abstrato e concreto deve considerar o contexto histórico-social do aluno, como orienta a Teoria Histórico-cultural. Esta foi uma busca constante do presente trabalho, voltada para a formação de conceitos em meio à tomada de consciência de condições e problemas sociais que atingem o aluno. Acreditamos que, ao longo da formação do aluno, a forma de abordagem da realidade concreta guarde diferenças entre os níveis de ensino. No ensino fundamental, o concreto com que a criança opera é mais próximo, mais imediato ou lúdico. Já no ensino médio, essa realidade imediata pode ser superada e expandida, conforme discutido em Leontiev (2012) sobre a 
necessidade que surge no aluno da escola secundária em "conhecer não apenas a realidade que o cerca, mas de saber também o que é conhecido acerca desta realidade" (p. 63).

Como observado na análise das interações discursivas de sala de aula, as situações-problema nas quais a necessidade tem origem social e está voltada para a apropriação do conceito químico, promovem a aproximação de conceitos espontâneos dos alunos aos conceitos científicos e vice-versa. Os conceitos espontâneos proporcionam concretude aos científicos e os científicos sistematizam os espontâneos (VIGOTSKI, 2009). Isso não quer dizer que todo conceito científico é um "ex-conceito espontâneo". O que ocorre é um apoio mútuo em que o conceito espontâneo pode ou não ser sistematizado até o nível de conceito científico. Não é o caso da entalpia, pois este conceito não existe no cotidiano extraescolar do aluno, mas pode ser o caso do conceito de combustível, que é um termo utilizado tanto no cotidiano quanto na ciência.

O processo de apropriação de conceitos científicos escolares é dificultado se os conceitos espontâneos não forem incluídos. No caso do episódio 8, "Relações entre os fatores energético e econômico no posicionamento da escolha entre álcool e gasolina", foi possível observar que o fornecimento de novos conceitos e novas condições para as ações e operações dos alunos são efetivos quando fazem parte de seus questionamentos, os quais estão repletos de conceitos espontâneos operados no senso comum e que precisam ser considerados e mediados.

A partir dessa observação, no decorrer da análise dos indícios de formação de conceitos, tivemos impressões como esta, que nos fizeram elaborar uma síntese, com o intuito de contribuir para próximas análises. Antes de colocá-la, é preciso dizer, como já sinalizamos na análise, que estamos entendendo os conceitos espontâneos do adolescente com algum grau de sistematização, o que, segundo Vigotski (2009), podem se referir aos pseudoconceitos ou conceitos transitórios, o que faz o conceito espontâneo ainda não possuir relações de generalidade suficientes com o sistema conceitual científico a ponto de ser um conceito científico, como se ainda estivesse "fora" desse sistema, sendo a sistematização proporcionada pelo 
conceito científico uma sistematização de "dentro para fora" do seu sistema conceitual.

Logo, quando se fala que os conceitos científicos sistematizam os espontâneos, pode parecer, ao nosso leitor, que consideramos que só os científicos sistematizam os espontâneos, pois estão prontos, postos, e já são conhecimentos produzidos pela humanidade. No entanto, para o aluno, o conceito científico e seu sistema não estão prontos, precisam ser apropriados. Assim, o conceito científico também precisa ser sistematizado no aluno, não só os espontâneos. Temos, então, duas sistematizações no processo de apropriação: a dos espontâneos e a dos científicos (de fora para dentro do sistema conceitual científico).

A partir disso, nossa síntese é de que a concretude proporcionada pelos conceitos espontâneos também contribui para a sistematização dos científicos. Não existe só a sistematização proporcionada pelos conceitos científicos aos espontâneos, de forma que, se o conceito científico for completamente novo para o aluno, sua sistematização terá de começar de alguma base, e esta base são os conceitos espontâneos. Observamos que, em conceitos como a entalpia, a sistematização interna entre os conceitos do sistema conceitual científico precisa ser apropriada pelo aluno, e, neste processo, os conceitos espontâneos auxiliam, proporcionando concretude a esta sistematização interna, ou seja, podem auxiliar na sistematização dos conceitos científicos.

Claro que não se trata de qualquer conceito espontâneo, mas aquele que proporciona uma base concreta. No caso da entalpia, por exemplo, o calor, como conceito espontâneo auxilia na sistematização interna da entalpia por meio de sua concretude.

Para nós, isso implica na importância da consideração, do uso dos conceitos espontâneos presentes na linguagem cotidiana do aluno, os quais possam servir de base para proporcionar a concretude que contribua para a sistematização dos conceitos científicos. Esta consideração faz parte da busca pela superação do ensino fechado em si mesmo, fechado apenas no conhecimento abstrato. Esta síntese corrobora com as discussões sobre conceitos espontâneos e científicos já realizadas em Vigotski (2009). 
Ainda em relação a análise dos indícios de formação de conceitos, gostaríamos de colocar uma síntese que possa vir a ser útil para as próximas análises.

Primeiramente, nos referimos a Vigotski (2009, p. 242): conceito é o significado da palavra. E seguimos com outras citações.

O significado guarda um movimento funcional, sua ação e suas formas de ação (operações) no mundo (LEONTIEV, 1983).

Em Libâneo e Freitas (2013) encontramos uma citação em que Davídov recorre a Espinosa para explicar o movimento do conceito de círculo. Espinosa concebe a assência do círculo no ato de sua construção. Conforme Espinosa "O círculo, segundo esta regra [...] deve definir-se assim: é a figura escrita por qualquer linha, um de cujos extremos é fixo e outro móvel". Aqui, segundo Davídov, se indica o método para obter quaisquer círculos infinitamente diversos.

A partir destas citações, e da definição que utilizamos para, por exemplo, o conceito de entalpia, segundo o qual a variação de entalpia do sistema, à pressão constante, é igual ao calor liberado ou absorvido, entendendo que o cálculo da variação de entalpia é, em si, a reprodução histórico-social de suas características funcionais e contém a essência do conceito, reproduzindo as ações e operações de uma atividade que o funcionaliza, o significa, e o concretiza, percebemos, ao longo da análise das interações discursivas a importância do conceito como ação mental, movimento do pensamento, e também ação no mundo e com o mundo. O conceito carrega uma ação, ou seja, uma atividade.

Logo, sugerimos que conceito é ação, de modo que não existe como conceito verdadeiro fora de sua atividade, que implica nas ações que interrelacionam o conceito em meio a seu sistema conceitual e a outros sistemas conceituais da realidade concreta. Estas ações se concretizam por meio da objetivação das necessidades da atividade. 
Neste processo, a objetivação se concretiza por meio das relações de generalidade determinadas pelo sistema conceitual, generalizações com conceitos espontâneos (concretizações e sistematizações) e entre conceitos científicos que transitam de um sistema conceitual a outro. As relações de generalidade geram sistematização interna ao sistema conceitual e as generalizações sistematizam para além do sistema conceitual.

Por isso, a apropriação do conceito é a reprodução de sua própria atividade no mundo, a qual não é isolada e está ligada a outras atividades humanas. Assim, conceito é movimento e também atividade, intencional e consciente. $O$ educador que transmite 0 conceito sem que os alunos reproduzam as suas formas de ação por meio de uma necessidade humana deste conceito, não está desenvolvendo conceitos científicos de forma crítica e consciente no aluno, limitando o desenvolvimento de competências cognitivas, da compreensão e transformação da realidade objetiva e de seu reconhecimento como sujeito na história da humanidade.

Disso deriva que a escolha dos conceitos científicos escolares a serem desenvolvidos com os alunos deve se basear no estudo de sua ação no mundo. Consideramos, aqui, que os conceitos da termoquímica são importantes para compor o entendimento dos processos energéticos da relação homem-mundo, com os quais os alunos se relacionam direta ou indiretamente, desde os que ocorrem no interior de seu organismo até os mais artificiais produzidos pela tecnologia. Sendo que, a partir do estudo desses conceitos, é possível desencadear a crítica a problemas socioambientais do contexto histórico-social do aluno.

A apropriação dos conceitos da termoquímica no texto produzido pelos alunos mostra a reprodução das formas histórico-culturais da atividade de crítica socioambiental do uso e produção de combustíveis pelo homem, em um movimento em que o conceito de combustível é unido ao contexto históricosocial dos alunos por meio das relações CTSA e das QSC. Isso nos mostra que, como instrumentos da atividade de ensino-aprendizagem, contribuem para a superação da ruptura entre conteúdo escolar e realidade históricosocial. No entanto, esta condição é determinada pela organização e mediação 
da atividade, que parte de uma necessidade real de caráter histórico-social, como no caso dos aspectos econômico e ambiental, unida ao objeto de estudo, como no caso dos conceitos da termoquímica.

Dessa forma, a análise dos indícios de formação de conceitos nos episódios de sala de aula e de apropriação dos conceitos nos textos dos alunos traz elementos importantes para a continuação e aprimoramento da nossa busca por aulas de química unidas à realidade histórico-social do aluno por meio da atividade de práxis.

Como já menciodado na Apresentação da pesquisa, as presenças e as ausências dos indícios de formação dos conceitos aqui identificadas, iniciam um apontamento de caminhos por onde devemos ou não devemos seguir nas trilhas da constante elaboração e reelaboração, da atividade de ensinoaprendizagem. Compondo a constante busca do educador pelo aprimoramento desta atividade.

Esta pesquisa se encontra em um momento de transição entre a utilização de QSC como instrumentos mediadores, que perpassam algumas ações da atividade de estudo, para a utilização das QSC como o problema real e controverso que desencadeia a atividade de estudo do conceito químico pelo aluno, como intencionado em Schneider-Felicio e Kato (2017).

Esperamos que este trabalho tenha contribuído para a construção de parte deste caminho, mesmo que inicial e inacabado, pois esperamos que seja o início, e não a finalização de nossos trabalhos com a Teoria da Atividade Histórico-Cultural.

\section{Referências}

AIKENHEAD G. S. What is STS science teaching? In: SOLOMON, J., AIKENHEAD, G. STS education: international perspectives on reform. New York: Teachers College Press, p.47-59, 1994.

Collective decision making in the social context of science.

Science Education, v. 69, n. 4, 1985. 
ALLCHIN, D. Teaching the Nature of Science: perspectives and resources. Ships Education Press: Saint Paul. 2013.

ASSOCIAÇÃO BRASILEIRA DE NORMAS TÉCNICAS. NBR 10520: informação e documentação: citações em documentos: apresentação. Rio de Janeiro, 2002.

ATKINS, P.; PAULA, J. Físico-Química, v.1. 8. ed. São Paulo: LCT, 2008.

AULER, D. Alfabetização científico-tecnológica: um novo "paradigma"? Ensaio: pesquisa em educação em ciências, v.5, n.1, p.1-16, 2003.

AULER, D., \& DELIZOICOV, D. Alfabetização científico-tecnológica para quê? Ensaio: pesquisa em educação em ciências, v.3, n.1, p.105-115, 2001.

Relações Estabelecidas por Professores: Neutralidade, Tecnocracia e Enfoque CTS. In: VIEIRA, Isabel P. Martins, Fátima Paixão E Rui Marques. (Org.). Perspectivas Ciência-TecnologiaSociedade na Inovação da Educação em Ciência. Aveiro, v.único, p.173177, 2004.

do educador Paulo Freire e referenciais ligados ao movimento CTS. Las Relaciones CTS en la Educación Científica. ISBN: 84-689-8925-8. 2006.

AULER, D. Interações entre Ciencia-Tecnolgia-Sociedade no Contexto da Formação de Professores de Ciências. Tese. 257p. (Doutorado em Educação). Universidade Federal de Florianópolis, 2002.

BARBOSA, L. G. D; LIMA, M. E. C. C; MACHADO, A. H. Controvérsias sobre o aquecimento global: circulação de vozes e de sentidos produzidos em sala de aula. Ensaio. Belo Horizonte. v.14. n.1. p.113-130. Jan-abr, 2012.

BELL, P. T.; ADKINS, A. D. GAMBLE, R. J.; SCHULTZ, R. D. Enthalpy Costs of Making and Breaking Bonds: A Game of Generating Molecules with Proper Lewis Structures. Journal of Chemical Education, v. 86, n. 4, p. 450-453, 2009.

BENITE, A. M. C.; SILVA, J. P.; A. C. Ferro, ferreiros e forja: o ensino de química pela lei no 10.639/03. Educação em Foco. Juiz de Fora, v. 21, n. 3, p. 735-768, 2016.

BERNSTEIN, B. A estruturação do discurso pedagógico: classe, códigos e controle. Petrópolis: Vozes, 1996.

BOGATAJ, L. K. Climate science literacy (Keynote). In: Symposium of the International Organization for Science and Technology Education (IOSTE), 14. Bled, Slovenia. Proceedings, 2010.

BOPEGEDERA, A. M. R. P.; PERERA, K. N. R. "Greening" a Familiar General Chemistry Experiment: Coffee Cup Calorimetry to Determine the Enthalpy of 
Neutralization of an Acid-Base Reaction and the Specific Heat Capacity of Metals. Journal of Chemical Education, v. 94, n. 4, p. 494-499, 2017.

BRAathen, P. C.; lustosa, A. A.; FOnTES, A. C.; SeVERINO, K. G. Entalpia de decomposição do peróxido de hidrogênio: um experiência simples de calorimetria com material de baixo custo e fácil aquisição. Química Nova na Escola. São Paulo, n. 29, p. 42-45, 2008.

BRITO, T. C.; CASTRO, D. L. Análise de concepções sobre energia química antes e depois de uma atividade de ensino sobre rotulagem de alimentos. Ciência em Tela, v. 3, n. 2, p. 1-25, 2010.

BRONFENBRENNER, U. A ecologia do desenvolvimento humano: experimentos naturais e planejados. Porto Alegre: Artes Médicas, 1996.

BRUNER, J. Actual minds, possible worlds. Cambridge, MA: Harvard University Press, 1986.

CACHAPUZ, F. A. Tecnociência, poder e democracia. In: SANTOS, W. L. P.; AULER, D. CTS e educação científica: desafios, tendências e resultados de pesquisas. Brasília: Editora Universidade de Brasília, 2011.

CAMILLO, J. Contribuições Iniciais para uma Filosofia da Educação em Ciências. Tese. 229p. (Doutorado em Ensino de Ciências - Ensino de Física) Universidade de São Paulo, São Paulo, 2015.

CAMILLO, J.; MATTOS, Educação em Ciências e a teoria da atividade cultural histórica: contribuições para a reflexão sobre tensões na prática educativa. Revista Ensaio. v.16, n. 01, p. 211-23, jan-abr, 2014.

CANDAU, V. M. F.; RUSSO, K. Interculturalidade e a Educação na América Latina: uma construção plural original e complexa. Rev. Diálogo Educ., Curitiba, v. 10, n. 29, p. 151-169, jan./abr. 2010

CANEN, A. Educação multicultural, identidade nacional e pluralidade cultural: tensões e implicações curriculares. Cadernos de Pesquisa, n. 111, p. 135149, dezembro, 2000.

CARVALHO, A. M. P. Uma metodologia de pesquisa para estudar processos de ensino e aprendizagem em sala de aula. (In): SANTOS, F. M. T.; GRECA, I. M. (Org). A Pesquisa em Ensino de Ciências no Brasil e suas metodologias. ljuí. Ed. Unijuí, 2011.

CARVALHO, H. W. P. BATISTA, A. P. L.; RIBEIRO, C. M. Ensino e aprendizado de química na perspectiva dinâmico-interativa. Experiências em Ensino de Ciências, v. 2, n. 3, p. 34-47, 2007.

CHANG, K. Learning Thermochemistry: Understanding the Challenges and Promoting Its Success. ProQuest LLC, 451p, Ph.D. Dissertation, University of California, Berkeley, 2009. 
CEDRO, W. L. O motivo e a atividade de aprendizagem do professor de Matemática: uma perspectiva histórico-cultural. 242 f. Tese (Doutorado em Educação). Faculdade de Educação, Universidade de São Paulo, São Paulo, 2008.

CHASSOT, A. Alfabetização científica: uma possibilidade para a inclusão social. Revista Brasileira de Educação. Jan/Fev/Mar/Abr. n.22, 2003.

CHEVALARD, Y. La transposición didáctica: del saber sábio al saber enseñado. Buenos Aires: Aique editores, 1991.

CLÉMENT, P. Science et idéologie: exemples en didactique et en épistémologie de la biologie. Actes du colloque Science - Médias - Société. Lyon: ENS-LSH, 2004. Disponível em <http://sciences-medias.ens Ish.fr/IMG/pdf/Clement.pdf>.

Didactic Transposition and KVP Model: Conceptions as Interactions Between Scientific knowledge, Values and Social Practices. ESERA Summer School. Braga, Universidade do Minho, p.9-18, 2006.

CONSELHO NACIONAL DE EDUCAÇÃO. Parecer CEB número 15 de1 junho de 1998. Parâmetros Curriculares Nacionais. Relatora Conselheira Guiomar Ramo Mello; processo: 23001.0030. 72p. 1998.

COSTA, A. O.; SÁ, I. C. G.; SILVA, A. F. A. Combustão X Queima: concepções de alunos da $1^{\underline{a}}$ série do ensino médio. XIV Encontro Nacional de Ensino de Química (XIV ENEQ). Anais. Curitiba, 2008.

CRESPO, L. C.; GIACOMINI, R. As atividades lúdicas no ensino de química: uma revisão da resvista Química Nova na Escola e das Reuniões Anuais da Sociedade Brasileira de Química. VIII Encontro Nacional de Ensino de Química (VIII ENEQ). Anais. Campinas, 2011.

CUNHA, M. I.; MARSICO, H. L.; BORGES, F. A.; TAVARES, P. Inovações pedagógicas na formação inicial de professores. In: FERNANDES, C. M. B.; GRILLO, M. (Orgs.). Educação superior: travessias e atravessamentos. Canoas: ULBRA, p.33-90, 2001.

DAMASCENO, H. C.; BRITO, M. S.; WARTHA, E. J.; As representações mentais e a simbologia química. XIV Encontro Nacional de Ensino de Química ENEQ. Anais. 2008.

DAVÍDOV, V. La enseñanza escolar y el desarrollo psíquico: investigaciónpsicológica teórica y experimental. Moscu: Editorial Progresso, 1988.

DAVÍDOV, V., MÁRKOVA, A. La concepcion de la actividad de estudio de los escolares In: DAVIDOV, V.; SHUARE, M. La psicología evolutiva y pedagogía en la URSS: antología. Moscú: Editorial Progreso, 1987. p.316336. 
DIAS, G. F. Educação Ambiental: princípios e práticas. 9. ed. São Paulo: Gaia, 2004.

DUNNE, J. Back to the rough ground. Notre Dame: University of Notre Dame Press, 1993.

ENGESTRÖM, Y. Non scolae sed vitae disimus: Como superar a encapsulação da aprendizagem escolar. In: HARRY, Daniels (Org.) Uma introdução a Vygotsky. São Paulo: Edições Loyola, 2002.

FABRÍCIO, C. M.; GUIMARÃES, L. M.; AIRES, J. A. Lavoisier e a combustão: uma proposta para o Ensino de Química baseada na História e Filosofia da Ciência. VIII Encontro Nacional de Ensino de Química (VIII ENEQ). Anais. Campinas, 2011.

FERREIRA, M. História da química e problematização no ensino de reações químicas. XIV Encontro Nacional de Ensino de Química (XIV ENEQ). Anais. Curitiba-PR, 2008.

FIRME, R. N. A abordagem ciência - tecnología - sociedade (CTS) no ensino da termoquímica: análise da construção discursiva de uma professora sobre conceitos científicos. Tese. 292 f. (Doutorado em Educação). Universidade Federal de Pernambuco, Recife, 2012.

FLOWER, R. Defining Popular Education. Disponível em https://www.unidue.de/imperia/md/content/eb-wb/defining popular education.pdf. Acesso em 07/10/2017

FREIRE, P. Pedagogia do Oprimido. 17.ed. Rio de Janeiro: Paz e Terra, 1987. $\overline{\text { Terra, } 1967 .}$

Educação como prática da liberdade. Rio de Janeiro: Paz e

A Educação na Cidade. 4.ed. São Paulo: Cortez, 2000.

FREITAS-REIS, I.; FARIAS, L. F. Abordando o tema alimentos embutidos por meio de uma estratégia de ensino baseada na resolução de casos: os aditivos alimentares em foco. Química Nova na Escola. São Paulo, v. 37, n. 1, p. 6370, fev, 2015.

GADOTTI, M. Materialismo Histórico Dialético e Educação: Estudos Introdutórios. São Paulo, 1983.

GADOTTI, M. Educação popular, educação social, educação comunitária. In: CONGRESSO INTERNACIONAL DE PEDAGOGIA SOCIAL, n. 1, São Paulo, 2012. Anais do Congresso Internacional de Pedagogia Social. São Paulo: USP, 2012.

GASPAR, A. Atividades experimentais no ensino de física: uma nova visão baseada na teoria de Vigotski. São Paulo: Ed. Livraria da Física, 2014. 
GOI, M. E. J.; SANTOS, F. M. T. Reações de combustão e impacto ambiental por meio de resolução de problemas. Química Nova na Escola, v. 31, n. 3, p. 203-209, agosto, 2009.

GROSSI, F. V. Popular education: Latin American experience. International Review of Education, V.30, p.303-314. 1984.

GUIMARÃES, M. A dimensão ambiental na educação. 11 ed. Campinas: Papirus, 2011.

HARRER, B. Identifying Productive Resources in Secondary School Students' Discourse about Energy. ProQuest LLC, 183 f. Ph.D. Dissertation, The University of 2013.2 Disponível em: https://dissexpress.proquest.com/dxweb/results.html?QryTxt=\&By=Benedikt+H arrer\&Title=Productive+Resources+in+Secondary+School+Students\%27+Disco urse+about+Energy\&pubnum=. Acesso em 10/10/2017.

HODSON, D. Putting your money where your mouth is: towards an actionoriented science curriculum. Journal for Activist Science \& Technology Education, v.1, n.1, p. 1-15, 2009.

HOLMAN, J. Editor's introduction: Science-technology-society education. International Journal of Science Education, v. 10, n. 4, p.343-345, 1988.

HURD, P. D. Scientific Literacy: New minds for a Changing World. Science Education, v. 82, n. 3, 407-416, 1998.

IGLESIA, P. M. Ciencia-Tecnología-Sociedad en la enseñanza-aprendizaje de las ciencias experimentales. Alambique dicáctica de las ciencias experimentales, v. 2, n. 3, p.7-11, 1995.

ISIDÓRIO, R. G.; SILVA, A. C. A.; QUADROS, A. L. Uma Introdução ao ensino de termoquímica para alunos da Educação de Jovens e Adultos, em uma perspectiva dialógica. Atas do IX Encontro Nacional de Pesquisa em Educação em Ciências - IX ENPEC Águas de Lindóia, SP - 10 a 14 de Novembro, 2013.

JAKUBOWSKA, A. A Student-Constructed Galvanic Cell for the Measurement of Cell Potentials at Different Temperatures. Journal of Chemical Education, v. 93, n. 5, p. 915-919, 2016.

JARA, O. Educación popular y cambio social en America Latina. Community Development Journal, Oxford, v.45, n.3, 2010.

KATO, D. S. O significado pedagógico da contextualização para o Ensino de Ciências. 116 f. Dissertação (Mestrado em Educação) -Universidade de São Paulo, Ribeirão Preto, 2007.

O papel dos cursinhos populares nos acessos e mudanças de

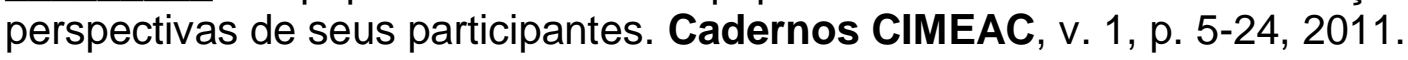


KEERATICHAMROEN, W. et al. The Tapioca Bomb: A Demonstration to Enhance Learning about Combustion and Chemical Safety. Teaching Science, v. 56, n. 1, p. $39-41,2010$.

KRASILCHIK, M. Prática de Ensino de Biologia. 4.ed. São Paulo: EDUSP, 2008.

LACASA, P. La escuela: uma sociedade dentro de otra? In: LACASA, P. (Org) Aprender em la escuela, aprender em la calle. Madrid: Visor, 1994.

LAYTON, D., DAVEY, A., JENKINS, E. Science for specific social purposes (SSSP): perspectives on adult scientific literacy. Studies in Science Education, n. 13, p.27-52, 1986.

LEDERMAN, N. G. Research on Nature of Science: Reflections on the Past, Anticipations on the Future. Asia-Pacific Forun on Science Learning and Teaching, volume 7, Issue 1. 2006. Disponível em https://www.eduhk.hk/apfslt/download/v7 issue1 files/foreword.pdf

LEE, C. K. A Conceptual Change Model for Teaching Heat Energy, Heat Transfer and Insulation. Science Education International, v. 25, n. 4, p. 417437, 2014.

LEONTIEV, A. N. O desenvolvimento do psiquismo. São Paulo: Moraes, 1978.

Pueblo y Educacion, 1983.

Actividad, conciencia, personalidad. 2.ed. Havana: Uma contribuição à teoria do desenvolvimento da psique infantil. In: VIGOTSKI, L. S.; LURIA, A. R.; LEONTIEV, A. N. Linguagem, desenvolvimento e aprendizagem. 12.ed. São Paulo: Ícone, 2012.

LEVINSON, R. Towards a theoretical framework for teaching controversial socio-scientific issues. International Journal of Science Education, v.28, n.10, p.1201-1224, 2006.

LEVINSON, R. A Theory of Curricular Approaches to the Teaching of SocioScientific Issues. Alexandria. v.1, n.1, p.133-151, mar 2008.

LIBÂNEO, J. C.; FREITAS, R. A. M. M. Vasily Vasilyevich Davydov: a escola e a formação do pensamento teórico e científico. In: LONGAREZI, A. M.; PUENTES, R. V. (Orgs.). Ensino Desenvolvimental: vida, pensamento e obra dos principais representantes russos. Série Ensino Desenvolvimental, v. 1. Uberlândia: EDUFU, 2013.

LINSINGEN, I. V. Perspectiva CTS: aspectos de um campo em consolidação na América Latina. Ciência \& Ensino. v.1, n especial, nov. 2007.

LONGAREZI, A. M.; FRANCO; P. L. J. A. N. Leontiev: a vida e a obra do psicólogo da atividade. In: LONGAREZI, A. M; PUENTES, R. V. (Orgs.). 
Ensino desenvolvimental: vida, pensamento e obra dos principais representantes russos. Uberlândia: EDUFU, 2013.

LOPES, A. R. C. Conhecimento escolar: ciência e cotidiano. Rio de Janeiro. Ed. Uerj. 1999.

LOUREIRO, C. F. B. Trajetória e fundamentos da Educação Ambiental. 2.ed. São Paulo: Cortez, 2006.

Teoria Social e Questão Ambiental: pressupostos para uma práxis crítica em Educação Ambiental. In: LOUREIRO, C. F. B.; LAYRARGUES, P. P.; CASTRO, R. S. (Orgs). Sociedade e meio ambiente: a educação ambiental em debate. São Paulo: Cortez, 2000, p. 14-51.

MARX, K.; ENGELS, F. A ideologia alemã. São Paulo: Martins Fontes, 1998.

MATTHEWS, M. R. Science teaching: the contribution of History and Philosophi of Science. 2. ed. New York: Routledge. 2015. Disponível em: https://books. google.com.br/books?hl=ptBR\& $\mathrm{r} r=\& \mathrm{id}=$ yoKQBAAAQBAJ\&oi=fnd\& pg=PP1\&dq=\%22MATTHEWS $+(2014) \% 22+\& o t s=g z G M J W u N \& s i g=a b 8 Y m e 6 \mathrm{~N}$ dqW 7wukhtXT5hLANag\&redir esc $=y \# v=$ onepage $\& q=\% 22 M A T T H E W S \% 20(2$ 014)\%22\&f=true . Acesso em 25/01/2016.

McCOMAS. W. F. Keys to Teaching the Nature of Science. NSTA WebNews Digest., 2004.2 Disponível em: https://www.eduhk.hk/apfslt/download/v7 issue1 files/foreword.pdf Acesso em 23/10/2016.

MENEZES, A. M.; et al. Validação de Sequências de Ensino-Aprendizagem em Aulas de Química de Escolas Secundárias do Estado de Sergipe-Brasil. IX Congreso Internacional sobre Investigación en Didáctica de las Ciencias. Girona, 2013.

MÉSZÁROS, István. A educação para além do capital. São Paulo: Boitempo, 2008.

MÉTIOUI, A.; McWILLIE, M. B. Pupil's Beliefs about the Transformations of Energy in Three Countries (Canada, France and Morocco). Universal Journal of Educational Research, v 3, n. 2, p. 75-84, 2015.

MILARÉ, T. A proposta metodológica de llha Interdisciplinar de Racionalidade em um curso de Licenciatura em Química: discutindo informações de corrente de e-mail. Química Nova na Escola. São Paulo, vol. 36, n. 2, p. 126-134, maio, 2014.

MILAGRES, V. S. O.; JUSTI, R. S. Modelos de ensino de equilíbrio químico: algumas considerações sobre o que tem sido apresentado em livros didáticos no Ensino Médio. Química Nova na Escola, n.13, maio, 2001.

MILLER, J. D. Scientific Literacy: A Conceptual and Empitical Revew. Daedalus: Journal of the American Academy of arts and Sciences, v. 112, n. 2, p. 29-48, 1983. 
MIZUKAMI, M. G. N. Ensino: as abordagens do processo. São Paulo: EPU, 1986.

MOLINA, M. C. Licenciaturas em Educação do Campo e o ensino de Ciências Naturais: desafios à promoção do trabalho docente interdisciplinar. Brasília: MDA, 2014.

MORADILLO, E. F.; OKI, M. C. M. Educação Ambiental na Universidade: Construindo Possibilidades. Quimica Nova, v. 27, n. 2, p. 332-336, 2004.

MORTIMER, E. F. Microgenetic analysis and the dynamic of explanation in science classroom. In: Conference for Sociocultural Research. 2000. Campinas - SP. Proceedings. Disponível em: http://www.fae.unicamp.br/br2000. Acesso em 27/06/2013.

Construtivismo, mudança conceitual e ensino de Ciências:

para onde vamos? Investigações em Ensino de Ciências, Porto Alegre, v. 1, n. 1, 1996.

MORTIMER, E. F.; SCOTT, P. Atividades discursivas na sala de aula de ciências: uma ferramenta sociocultural para analisar e planejar o ensino. Investigações em Ensino de Ciências. v.7, n.3, p.283-306, 2002.

MOURA, M. O.; ARAÚJO, E. S.; MORETTI, V. D.; PANOSSIAN, M. L.; RIBEIRO, F. D. Atividade Orientadora de Ensino: unidade entre ensino e aprendizagem. Rev. Diálogo Educ., Curitiba, v.10, n.29, p.205-229, jan./abr. 2010.

MOURA, M. O.; LANNER de MOURA, A. R. Escola: um espaço cultural. Matemática na educação infantil: conhecer, (re)criar - um modo de lidar com as dimensões do mundo. São Paulo: Diadema/SECEL, 1998.

MOURA, M. O. O educador matemático na coletividade de formação: uma experiência com a escola pública. Tese (Livre Docência em Metodologia do Ensino de Matemática). Faculdade de Educação. Universidade de São Paulo, São Paulo, 2000.

MUELLER, S. A.; ANDERSON, J.; WALLINGTON, T. J. A Classroom Demonstration of Water-Induced Phase Separation of Alcohol-Gasoline Biofuel Blends. Journal of Chemical Education, v. 86, n. 9, p. 1045-1048, 2009.

NúÑEZ, I. B. Vigotski, Leontiev, Galperin: formação de conceitos e princípios didáticos. Brasília: Liber Livro, 2009.

NÚÑEZ, I. B.; OLIVEIRA, M. V. F. P. Ya. Galperin: a vida e a obra do criador da teoria da formação por etapas das ações mentais e dos conceitos. In: LONGAREZI, A. M.; PUENTES, R. V. (Orgs.). Ensino Desenvolvimental: vida, pensamento e obra dos principais representantes russos. Série Ensino Desenvolvimental, v. 1. Uberlândia: EDUFU, 2013.

NARITA, F. Z. Temas, conceitos e processos em Educação Popular: uma discussão a partir das ciências sociais. Cadernos CIMEAC, v.4, n.2, 2014. 
OLIVEIRA, M. K. Aprendizado e desenvolvimento: um processo sóciohistórico. 4.ed. São Paulo: Editora Scipione, 2002.

OLIVEIRA, R. R.; FRAGA, J. S. Integrando processos sociais e ecológicos: o metabolismo social de três sistemas produtivos históricos do Estado do Rio de Janeiro. In: Anais do XXVI Simpósio Nacional de História - ANPUH. São Paulo, julho 2011.

OLIVER-HOYO, M. T.; PINTO, G; LLORENS-MOLINA, J. A. The Chemistry of Self-Heating Food Products: An Activity for Classroom Engagement. Journal of Chemical Education, v. 86, n. 11, p. 1277-1280, 2009.

OPITZ, S. T. et al. Students' Energy Concepts at the Transition between Primary and Secondary School. Research in Science Education, v. 45, n. 5, p. $691-715,2015$.

ORDENES, R., et al. Representaciones macroscópicas, submicroscópicas y simbólicas sobre la materia. Educ. Quím. v.25, n.1, p.46-55, 2014.

OULTON, C. DAY, V.; DILLON, J.; GRACE, M. Controversial issues: teachers' attitudes and pratices in the context of citizenship education. Oxford Revew of education, v. 30, n. 4, p. $489-507,2004$

OULTON, C.; DILLON, J.; GRACE, M. Reconceptualinzing the teaching of controversial issues. International Journal of Science Education, v. 26, n. 4, p. 411-423, 2004

PEDRETTI, E. G. et al. Promoting issues based STSE: perspectives in Science teaching education: problems with identity and ideology. Science \& Education, v. 17, n. 8-9, p. 941-960, 2008.

PEDRETTI, E., \& HODSON, D. From rhetoric to action: Implementing STS education through action research. Journal of Research in Science Teaching, v. 32, p. 463-485, 1995.

PULIDO, M. D.; SILVA, A. N. Do calórico ao calor: uma proposta de ensino de química na perspectiva histórica. História da Ciência e Ensino, v. 3, p. 52-77, 2011.

PUNCKT, C. Wildfires in the Lab: Simple Experiment and Models for the Exploration of Excitable Dynamics. Journal of Chemical Education, v 92, n. 8, p. 1330-1337, 2015.

RAMSEY, J. The science education reform movement: implications for social responsibility. Science Education, v. 77, n. 2, p.235-258, 1993.

RATCLIFFE, M.; GRACE, M. Science education for citizenship: teaching socio-scientific issues. Maidenhead: Open University Press, 2003.

REIS, P. Uma iniciativa de desenvolvimento profissional para a discussão de controvérsias sóciocientíficas em sala de aula discussão. Interacções, v. $2, \quad$ n. $4, \quad$ p.64-104, $2006 . \quad$ Disponível em: 
http://revistas.rcaap.pt/interaccoes/issue/view/As\%20controv\%C3\%A9rsias\%20 sociocient\%C3\%ADficas\%20e\%20s\%C3\%B3cioambientais\%20na\%20educa\%C3\%A7\%C3\%A30\%20em\%20ci\%C3\%AAncias \%20e\%20na\%20educa\%C3\%A7\%C3\%A30\%20ambiental.

REIS, P. R. Os temas controversos na Educação Ambiental. Pesquisa em Educação Ambiental. Ribeirão Preto. v.2, n.1. p.125-141. jan/jun, 2007.

RODRIGUES, A. M.; MATTOS, C. R. Reflexões sobre a noção de significado em contexto. Indivisa, Boletín de Estudios e Investigación, 7, p. 323 - 333, 2007.

RUBBA, P. A., WIESENMAYER, R. Goals and competencies for precollege STS education: recommendations based upon recent literature in environmental education. Journal of environmental Education, v. 19, n. 4, p.38-44, 1988.

SADLER, T. D. Informal reasoning regarding socioscientific issues: a critical review of research. Journal of Research in Science Teaching. v.41, n.5, p.513-536, 2004.

; AMIRSHOKOOHI, A.; KAZEMPOUR, M.; ALLSPAW, K. M. Socioscience and Ethics in Science Classrooms: Teacher Perspectives and Strategies. Journal of Research in Science Teaching, v.43, p.353-376, 2006.

SADLER, T. D; FOWLER, S. R. A Threshol Model of Content Knowledge transfer for Socioscientific Argumentation. Wiley Interscience. 2006.

RUBTSOV, V. A atividade de aprendizado e os problemas referentes à formação do pensamento teórico dos escolares. In: GARNIER, C. et al. (Org.). Após Vygotsky e Piaget: perspectivas social e construtivista escolas russa e ocidental. Porto Alegre: Artes Médicas, 1996.

SACRISTÁN, J. Gimeno. O Currículo: Uma reflexão sobre a prática. 3. ed. Porto Alegre: Artmed Editora, 2000.

SANGIOGO, F. A.; WOYCIECHOSWSKY, R.; ROSA, S. A.; MALDANER, O. A. A pesquisa educacional como atividade curricular na formação de licenciandos de química. Ciência \& Educação, v. 17, n. 3, p. 523-540, 2011.

SANTOS, M. E. Encruzilhadas de mudança no limiar do século XXI: coconstrução do saber científico e da cidadania via ensino CTS de ciências. In: Encontro Nacional de Pesquisa em Educação em Ciências, Valinhos. Atas.Valinhos, 1999.

SANTOS, W. L. P. Aspectos sociocientíficos em aulas de química. Tese Doutorado. Faculdade de Educação da Universidade Federal de Minas Gerais. 2002. 
. Educação Científica humanística em uma perspectiva Freireana: Resgatando a função do ensino de CTS. Alexandria, v.1, n.1, p.109-131, 2008.

. Significados da educação científica com enfoque CTS. In: SANTOS, W. L. P.; AULER, D. (Orgs.). CTS e educação científica: desafios, tendências e resultados de pesquisas. Brasília: Editora Universidade de Brasília, 2011.

Contextualização no Ensino de Ciências por meio de temas CTS em uma perspectiva crítica. Ciência \& Ensino, v. 1, n. especial, novembro, 2007.

SANTOS, W. L. P.; MORTIMER, E. F. Abordagem de aspectos sociocientíficos em aulas de ciências: possibilidades e limitações. Investigações em Ensino de Ciências, v.14, n.2, p.191-198, 2009.

Uma análise de pressupostos teóricos da abordagem C-T-S (Ciência-Tecnologia-Sociedade) no contexto da educação brasileira. Ensaio - Pesquisa em Educação em Ciências. v.2. n.2. Dez. 2002.

SANTOS, W. L. P.; SCHNETZLER, R. P. Educação em Química: compromisso com a cidadania. ljuí:Unijuí. 4.ed. 2010.

SARICAYIR, H. et al. Determining Students' Conceptual Understanding Level of Thermodynamics. Journal of Education and Training Studies, v. 4, n. 6, p. 69-79, 2016.

SASSERON, L. H.; CARVALHO, A. M. P. Almejando a Alfabetização Científica no Ensino Fundamental: a proposição e a procura de indicadores do processo. Investigações em Ensino de Ciências. v.13, n.3, p.333-352, 2008.

Alfabetização Científica: uma revisão bibliográfica. Investigações em Ensino de Ciências. v.16, n.1, p.59-77, 2011.

SAVIANI, D. A pedagogia histórico-crítica e a educação escolar. In: BERNARDO, M. (Org.). Pensando a educação. São Paulo: EDUNESP, 1989.

SHAMOS, M. H. The myth of scientific literacy. New Brunswick: Rutgers University Press, 1995.

SCHNEIDER-FELICIO, B. V. A Relação entre as Dimensões Ambiental e Química: uma Análise das Produções dos Encontros Nacionais de Pesquisa em Educação em Ciências no Período de 1997 a 2009. Dissertação. 132 p. (Mestrado em Ensino de Ciências). IF/IQ/IB/FE, Universidade de São Paulo, São Paulo, 2012.

SCHNEIDER-FELICIO, B. V.; KATO, D. S. A abordagem de questões sociocientíficas em aulas de química: reflexões sobre o processo de apropriação de conceitos submicroscópicos na educação do campo. Enseñanza de las Ciencias, n. extraordinário, p. 4825-4830, 2017. 
SILVA, A. C. T. Estratégias enunciativas em sala de aula de química: contrastantdo professores de estilos diferentes. Tese. $477 \mathrm{f}$. (Doutorado em Educação). Universidade Federal de Minas Gerais, Belo Horizonte, 2008.

SILVA, J. L. P. Porque não estudar entalpia no ensino médio. Química Nova na Escola. n 22, p. 22-25, novembro, 2005.

SILVA, M. A. E.; PITOMBO, L. R. M. Como os alunos entendem queima e combustão: contribuições a partir das representações sociais. Química Nova na Escola, n. 23, maio, 2006.

SILVA, P. T. B.; ARAÚJO, M. I. O. Diálogos sobre interculturalidade, conhecimento científico e conhecimentos tradicionais na educação escolar indígena. Práxis Educacional, Vitória da Conquista, v. 11, n. 18 p. 153-176 jan./abr. 2015

SOARES, M. H. F. B. O Lúdico em Química: jogos e atividades aplicados ao ensino de química. Tese. 219 f. (Doutorado em Ciências). Universidade Federal de São Carlos, São Carlos, 2004.

SOARES, M. H. F. B.; CAVALHEIRO, É. T. G. O ludo como um jogo para discutir conceitos em termoquímica. Química Nova na Escola, São Paulo, n. 23, maio, 2006.

SOLOMON, J. The UK and the movement for Science, technology and society (STS) education. In: CROSS, Roger (Org.). A vision for science education: responding to the work of Peter Fensham. London: Routledge Falmer, 2003, p. $76-90$.

Open University Press, 1993.

Teaching science, technology and society. Buckingham: The discussion of a social issues in the Science classroom. Studies in Science Education, v. 18, n. 1, p. 105-126, 1990.

SOUZA, V. C. A. JUSTI, R. Estudo da utilização de modelagem como estratégia para fundamentar uma proposta de ensino relacionada à energia envolvida nas transformações químicas. Revista Brasileira de Pesquisa em Educação em Ciências, v. 10, n. 2, p. 2010.

STIEFEL, B. M. La naturaleza de la ciencia en los enfoques CTS. Alambique dicáctica de las ciencias experimentales, v. 2, n. 3, p.19-29, 1995.

TARHAN, L.; AYYILDIZ, Y.; OGUNC, A.; SESEN, B. A. A Jigsaw Cooperative Learning Application in Elementary Science and Technology Lessons: Physical and Chemical Changes. Research in Science \& Technological Education, v. 31, n. 2, p. 184-203, 2013.

TEIXEIRA, P. M. M. Educação Científica por meio da Pedagogia HistóricoCrítica e do movimento C.T.S. no Ensino de Ciências. Ciência \& Educação, v.9, n.2, p.177-190, 2003. 
TUNES, E.; PRESTES, Z. Vigotski e Leontiev: ressonâncias de um passado. Cadernos de pesquisa. v.39, n.136, p.285-314, jan./abr, 2009.

VIANNA, A. N. Núcleos de significação: uma proposta de análise revisitada pelo olhar bakhtiniano. In: FREITAS, M. T. de A.; RAMOS, B. S. (Orgs.). Fazer Pesquisa na abordagem histórico-cultural: metodologias em construção. Juiz de Fora, Minas Gerais: UFJF, 2010.

VIGOTSKI, L. S. Psicologia da Arte. São Paulo: Martins Fontes. 1999.

Paulo: Martins Fontes. 2009.

A construção do pensamento e da linguagem. 2.ed. São A formação social da mente. São Paulo: Martins Fontes.

2007.

Obras Escogidas IV. Madrid: Visor, 1996.

VILCHES, A.; PÉREZ, D. G.; PRAIA, J. De CTS a CTSA: educação por um futuro sustentável. In: SANTOS, W. L. P; AULER, D. (Orgs.). CTS e educação científica: desafios, tendências e resultados de pesquisa. Brasília: Editora Universidade de Brasília, 2011, p. 161-184.

VISINTAINER, T.; LINN, M. Sixth-Grade Students' Progress in Understanding the Mechanisms of Global Climate Change. Journal of Science Education and Technology, v. 24, n. 2-3, p. 287-310, 2015.

WARTHA, E. J; REZENDE, D. B. R. Os níveis de representação no ensino de química e as categorias da semiótica de Peirce. Investigações em Ensino de Ciências. v.16, n.2, p.275-290, 2011.

ZABALA, A. A prática educativa: como ensinar. Porto Alegre: Artmed, 1998.

ZEIDLER, D. L. et al. beyond STS: a research-based framework for socioscientific issues education. Science education. v.89. n.3, p.357-377, 2005.

Tangled up views: beliefs in the nature of science and responses to socioscientific dilemmas. Science education. v.86. n.3, p.343-367, 2002.

ZEIDLER; D. L.; KEEFER, M. The role of moral reasoning and the status of socioscientific issues in science education. In: ZEIDLER; D. L. The Role of Moral Reasoning on Socioscientific Issues and Discourse in Science Education. Kluwer Academic Publishers. Printed in the Netherlands, 2003. 


\section{APÊNDICES}

\section{APÊNDICE A Sequência de atividades e tabelas de apoio}

\section{AULA 1 - CIÊENCIAS NATURASS}

Matriz energética: qual a parte que me cabe neste latifúndio?

\section{Introdução}

Ao passar do tempo, o estilo de vida adotado pelo homem necessita e depende, cada vez mais, de energia sob diversas formas, tanto que o setor energético se tornou um dos setores de maior investimento entre os países desenvolvimentistas, já que a energia possibilita meios para a produtividade, e o aumento da produtividade dos diversos setores sustenta toda a economia. Mas de onde vem essa energia? Da natureza, certo? Pensando em proporções de um país, ou seja, em grande escala, como o homem retira energia da natureza e usa ao seu favor? Sob que forma essa energia pode ser aproveitada? Quais as implicações e quais impactos são causados por essa retirada, por essa exploração das diversas fontes de energia da natureza?

Quando falamos no conjunto de todos os tipos de fontes de energia que um país possui em seu território, estamos falando de sua matriz energética. $O$ Brasil tem um potencial energético que comporta diversas fontes de energia, como o vento, a água, o carvão, o petróleo, o gás natural, a biomassa e a alta incidência de raios solares. Se considerarmos estas sete fontes de energia, quatro delas são renováveis, o que proporciona ao país um potencial para uso sustentável de sua matriz energética. Mas como o potencial não corresponde ao que realmente está sendo aproveitado, muitas pesquisas e investimentos ainda precisam ser realizados para que o uso sustentável dessas fontes se concretize.

Dentre as fontes energéticas exploradas no Brasil, o maior destaque até os dias atuais é o petróleo, explorada há mais de 60 anos no território nacional. Os investimentos em pesquisa tecnológica permitem à PETROBRAS expandir significativamente suas reservas com a descoberta da camada Pré Sal, tornando-se a maior empresa do mundo em exploração de petróleo em águas profundas. Esta nova reserva pretende atender as demandas energéticas do país, de modo que o Brasil seja autossuficiente energeticamente e continue avançando em pesquisas, inclusive no que diz respeito à produção de combustíveis alternativos. Logo, a exploração do Pré Sal, que mesmo sendo uma fonte de energia não renovável, tem potencial em fornecer subsídio financeiro para, ao longo dos anos, aumentar o investimento em pesquisas de desenvolvimento de energias renováveis que continuarão sustentando o país no caso do esgotamento das fontes de energia não renováveis.

Dentre as fontes de energia consideradas renováveis, sabemos que a mais explorada é a hidráulica para o fornecimento de energia elétrica e a biomassa da cana de açúcar para fornecimento de combustível. Será que a qualidade "renovável" dessas fontes implica em sustentabilidade para as 
futuras gerações e para o meio ambiente do nosso país? Quais as implicações trazidas pela Revolução Verde à nossa sociedade?

Além disso, você deve (e deveria mesmo) estar pensando: o que todo esse papo de matrizes energéticas tem a ver com a minha vida? Como uma comodity tão distante de mim como o petróleo, por exemplo, vai influenciar no meu dia a dia? Ou influenciará algum dia? Pois bem, podemos começar com uma questão bem simples: você pretende ter e usar um carro para se locomover até o fim da vida? Se sim, quando for adquirí-lo, pensará apenas no modelo e na cor? No rendimento do motor e qual combustível usa, talvez? Preferirá o motor que use o combustível mais barato? Ou Flex? Ou o que polua menos o ar? Seja sincero. Pensaria mesmo no meio ambiente? Ou somente nos fatores econômicos que afetam o seu bolso? Será que pensar individualmente não traz prejuízos futuros para o próprio sujeito? E se procurássemos entender mais a fundo a origem e os processos por que passam os combustíveis que tanto utilizamos, desde sua matriz energética até seu consumo final? Será que os fatores a serem considerados na escolha de um carro se resumiriam apenas em rendimento e poluição? $O$ que a administração da matriz energética brasileira tem a ver com a escolha do seu futuro carro?

\section{0 problema}

Vamos, então, pensar a escolha de um carro sob vários pontos de vista: econômico, ambiental, social, político, todos em função dos principais combustíveis que temos à nossa disposição no mercado, ou seja, os principais combustíveis utilizados no país em veículos leves - álcool e gasolina - e também em um combustível menos utilizado que os primeiros, mas que vem sendo objeto de pesquisas pelo seu potencial energético e ambiental - 0 biodiesel.

Imagine que você e cada membro de seu grupo receberá uma carta de crédito no valor de $R \$ 30.000$, que poderá ser utilizada por cada um de vocês, de maneira pessoal e intransferível, na compra de seu carro.

O objetivo da aula é o grupo comparar as características destes combustíveis, partindo das considerações sobre rendimento e poluição, e estendendo estes fatores iniciais a outros fatores relacionados, a fim de refletirmos se temos realmente noção dos processos que envolvem a obtenção e o uso dos combustíveis mais usados nos carros disponíveis no mercado.

Para cada etapa, a seguir, serão considerados três tipos de combustível: gasolina, álcool e biodiesel, e cada dupla do grupo de 6 componentes ficará responsável por apenas um tipo de combustível para que, no momento das discussões, sejam compartilhadas as semelhanças, diferenças e relações existentes entre os três combustíveis.

Então, para começarmos a pensar no carro que desejamos, vamos começar pelo seu desempenho relacionado ao tipo de combustível utilizado:

1. De onde vem o desempenho energético do combustível? Como posso calculá-lo? Qual combustível é mais energético? Entre álcool e gasolina, qual compensa mais economicamente?

(Energia liberada pelo combustível em sua queima completa, em $\mathrm{kJ} / \mathrm{mol})$. 


\begin{tabular}{|l|l|l|}
\hline Álcool & Gasolina & Biodiesel \\
\hline & & \\
\hline
\end{tabular}

2. Quais são os riscos envolvidos na poluição atmosférica gerada pela liberação de $\mathrm{CO}_{2(\mathrm{~g})}$ proveniente da queima desses combustíveis? A que conclusão chegamos sobre qual combustível seria menos poluente ao compararmos as quantidades de $\mathrm{CO}_{2(\mathrm{~g})}$ liberadas nas reações de queima dos combustíveis e confrontarmos os fatores "a" e "b"?:

a) Quantidade de $\mathrm{CO}_{2(\mathrm{~g})}$ liberada pela queima do combustível, em mol.

\begin{tabular}{|l|l|l|}
\hline $\mathrm{CO}_{2(\mathrm{~g})}-$ Álcool & $\mathrm{CO}_{2(\mathrm{~g})}-$ Gasolina & $\mathrm{CO}_{2(\mathrm{~g})}-$ Biodiesel \\
\hline
\end{tabular}

b) Existência de renovabilidade do $\mathrm{CO}_{2(\mathrm{~g})}$ liberado pela queima do combustível. Em caso positivo, como ocorre?;

\begin{tabular}{|c|c|c|}
\hline Álcool & Gasolina & Biodiesel \\
\hline & & \\
\hline
\end{tabular}

3. No item anterior, pensamos em um aspecto da poluição do ar gerada pela queima do combustível (uso final) comparada com a sua produção (origem). Continuando a pensar na origem do combustível, podemos apontar outras formas de poluição, mesmo para o caso dos combustíveis renováveis. A água, o solo, a biodiversidade da fauna e flora podem sofrer impactos ambientais dependendo do modo de produção utilizado para o cultivo da cana-de-açúcar e da soja. A grande bandeira da renovabilidade energética utilizada para defender a alta produtividade das monoculturas em larga escala para exportação, advindas da revolução verde, ameaçam o meio ambiente de diversas formas, desconhecidas pelo consumidor do produto final. Vamos pensar sobre como os combustíveis renováveis são produzidos em larga escala em nosso país e quais impactos podem causar aos itens abaixo?

a) Solo. Como a monocultura da cana-de-açúcar e da soja polui/prejudica o solo?

b) Água. Como a monocultura em larga escala causa poluição das águas dos rios?

c) Biodiversidade (fauna). Como a monocultura prejudica a biodiversidade da fauna nativa?

d) Biodiversidade (flora). Idem c. Considere também a adoção de sementes transgênicas.

4) Estendendo o pensamento sobre a poluição e os impactos ambientais dessa monocultura em larga escala para consequências na vida dos trabalhadores do campo, o que mais podemos identificar de contraditório entre a bandeira da renovabilidade energética dos biocombustíveis e o modo de produção dos mesmos? 
5) Além da produção de biocombustíveis, qual outro setor produtivo é atingido pelos mesmos impactos ambientais e sociais? Quem, além dos trabalhadores rurais, também sofre essas consequências? $O$ que 0 conceito de entalpia de combustão tem a ver com isso?

6) Como esse cenário da monocultura poderia ser revertido para um modo sustentável da produção e uso dessas fontes de energia? Existem alternativas para o sistema produtivo da monocultura?

\section{PRIMEIRO DIA}

Em um primeiro momento, há uma discussão introdutória sobre matrizes energéticas brasileiras, conforme explicitado no texto introdutório, até que o problema seja introduzido. Os grupos são divididos e os direcionamentos são dados. Durante o trabalho dos grupos, os professores acompanham os alunos, fazendo a mediação de informações para sanar dúvidas, podendo fazer retomadas ou introdução de conceitos necessários, tais como: combustão, combustível, matriz energética, entalpia, renovabilidade do combustível, sustentabilidade, dentre outros. Foram realizados os itens 1 e 2 do problema.

\section{SEGUNDO DIA}

Continuação da discussão com os grupos. Para o item 3 e os demais itens subsequentes, foi realizada uma discussão prévia envolvendo 0 conhecimento dos alunos sobre o tema e, em seguida, foi feita a exibição de trechos do documentário "O veneno está na mesa" ${ }^{32}$, visando fomentar discussões sociais, com o objetivo de se chegar a uma conclusão sobre 0 cenário de escolhas que atualmente dispomos diante do que nos é oferecido em termos de fontes de energia voltadas aos combustíveis para carro e, consequentemente, como a escolha de um carro ou do combustível a ser usado num carro está relacionada a aspectos de administração da matriz energética brasileira, explicitando-se a tomada de consciência sobre as semelhanças dos sistemas produtivos de combustíveis e de alimentos, juntamente com a ampliação do conceito de entalpia de combustão para a respiração celular. A finalização da aula se dá com a elaboração de um texto pelos alunos, justificando uma possível escolha de um carro baseada em seu combustível e nas discussões feitas durante a aula.

\section{Materiais necessários}

Livros didáticos de química e biologia.

\footnotetext{
32 Documentário de Silvio Tendler, experiente documentarista brasileiro, que revela que $28 \%$ dos alimentos oferecidos à população brasileira são insatisfatórios para consumo. Baseado em dossiê da Associação Brasileira de Saúde Coletiva (Abrasco), divulgado em 2012, o filme mostra que desde 2008, quando ultrapassou os Estados Unidos, o Brasil é o país que mais utiliza agrotóxicos no mundo. Elaborado por pesquisadores de diversas universidades federais brasileiras, o extenso relatório da Abrasco reúne dados oficiais e uma série de estudos que denunciam o descontrole do uso de agrotóxicos no Brasil e comprovam os graves e diversificados danos à saúde e ao meio ambiente, provocados pelo uso de biocidas.
} 
Aparatos para exibir o documentário.

\section{Tabelas}

Tabela 1 Entalpias padrão de formação $\Delta_{\mathrm{f}} \mathrm{H}^{\theta}\left(\mathrm{kJ} \mathrm{mol}^{-1}\right)$ a $298 \mathrm{~K}^{*}$

\begin{tabular}{|c|c|c|c|}
\hline Compostos & Fórmula molecular & $\Delta_{\mathrm{f}} \mathrm{H}^{\theta}\left(\mathrm{kJ} \mathrm{mol}^{-1}\right)$ & $\Delta \mathrm{cH}^{\theta}\left(\mathrm{kJ} \mathrm{mol}^{-1}\right)$ \\
\hline Gasolina (octano) & $\mathrm{C}_{8} \mathrm{H}_{18(I)}$ & -250 & \\
\hline Gasolina (heptano) & $\mathrm{C}_{7} \mathrm{H}_{16(I)}$ & -224 & \\
\hline Álcool (etanol) & $\mathrm{C}_{2} \mathrm{H}_{5} \mathrm{OH}_{(\mathrm{I})}$ & -278 & \\
\hline Álcool (metanol) & $\mathrm{CH}_{3} \mathrm{OH}_{(1)}$ & -239 & \\
\hline GNV (metano) & $\mathrm{CH}_{4(\mathrm{~g})}$ & -75 & \\
\hline $\begin{array}{l}\text { Biodiesel (oleato de } \\
\text { metila) }\end{array}$ & $\mathrm{C}_{19} \mathrm{H}_{36} \mathrm{O}_{2(l)}$ & $-728^{* *}$ & \\
\hline $\begin{array}{l}\text { Biodiesel (linoleato de } \\
\text { metila) }\end{array}$ & $\mathrm{C}_{19} \mathrm{H}_{34} \mathrm{O}_{2(l)}$ & $-606^{* *}$ & \\
\hline Carvão (grafite) & $C_{(s)}$ & 0 & \\
\hline Oxigênio & $\mathrm{O}_{2(\mathrm{~g})}$ & 0 & \\
\hline Água & $\mathrm{H}_{2} \mathrm{O}_{(\mathrm{g})}$ & -242 & \\
\hline Dióxido de carbono & $\mathrm{CO}_{2(\mathrm{~g})}$ & -394 & \\
\hline Monóxido de carbono & $\mathrm{CO}_{(\mathrm{g})}$ & -111 & \\
\hline
\end{tabular}

*Valores de entalpia retirados de Atkins \& de Paula. Físico-Química. v. 1. 8.ed. LCT **Valores retirados de Silva, M. V. R. Modelagem molecular aplicada a reações de produção do Biodiesel (dissertação) 94p. Mestrado em Engenharia Química. UFU. MG. 2012.

Tabela 2 Rendimento do motor 1.0 Wolkswagen UP! 2015 (INMETRO)

\begin{tabular}{|l|l|l|}
\hline Combustível & Cidade & Rodovia \\
\hline Gasolina & $13,5 \mathrm{Km} / \mathrm{L}$ & $14,6 \mathrm{Km} / \mathrm{L}$ \\
\hline Álcool & $9,2 \mathrm{Km} / \mathrm{L}$ & $10,2 \mathrm{Km} / \mathrm{L}$ \\
\hline
\end{tabular}

Tabela 3 Preço do combustível. Posto BR Vila Tibério, Ribeirão Preto, 17/06/2015.

\begin{tabular}{|c|c|}
\hline Combustível & Preço em Reais \\
\hline Gasolina comum & 3,26 \\
\hline Gasolina aditivada & 3,29 \\
\hline Etanol & 1,95 \\
\hline
\end{tabular}


257

APÊNDICE B Textos produzidos pelos alunos

Texto 1

Qcauro morido a igás naturd d'muito mais eccoromico que a gasdinc pai se encontra prusoizada.

Ugaratinc tem mior pader de condusto componada com o Gais nduals o dead.

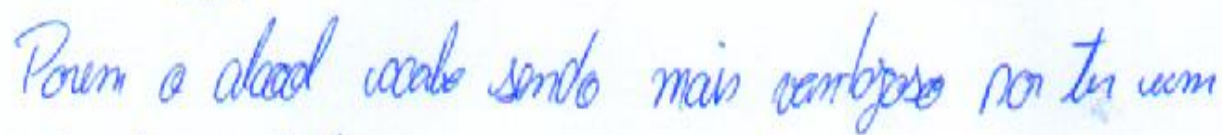

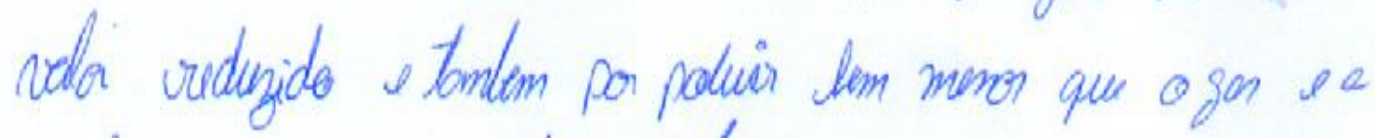
gasadino mas po autho lado proporacono un unom injocts

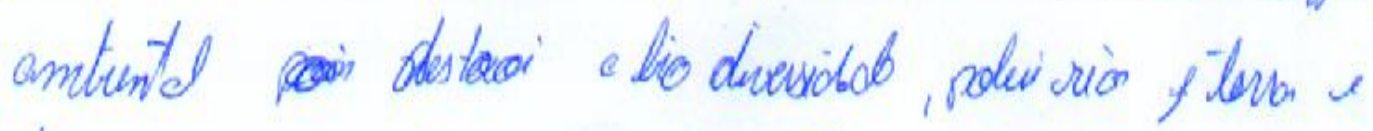
dio an com a wo do agrotoxion na platiocian

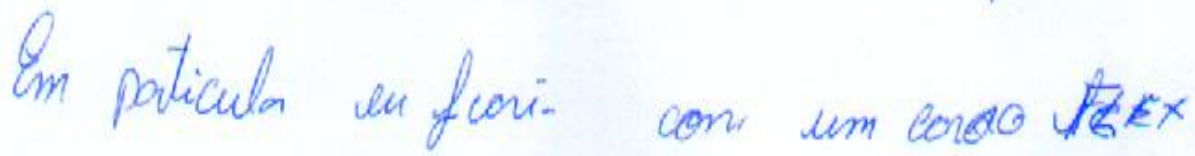

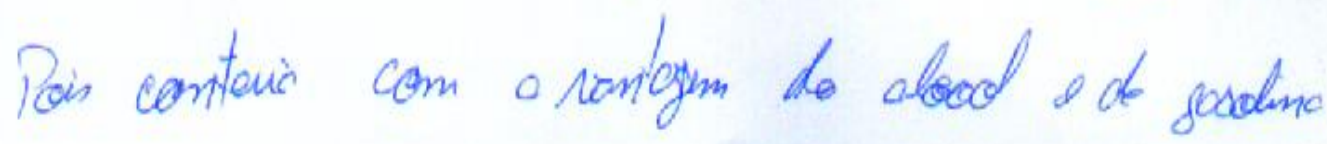
200 mesmo tenpo investerir en uma opico mais

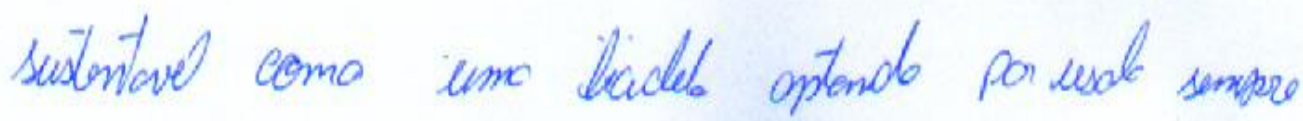
quardo fos pociuel. 


\section{Texto 2}

$\rightarrow$ FLeX

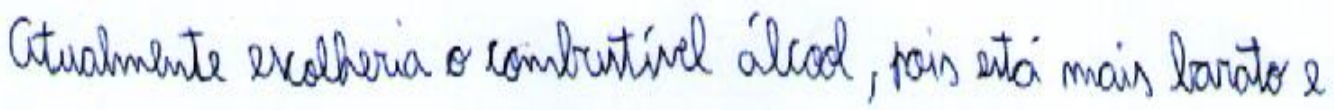
regundo as contas de rendimbito ertá compentando até o salor de RS 2,25. Clém de que norui menos $\mathrm{CO}_{2}$ liberado comparado ovos com. butinis concorrentes

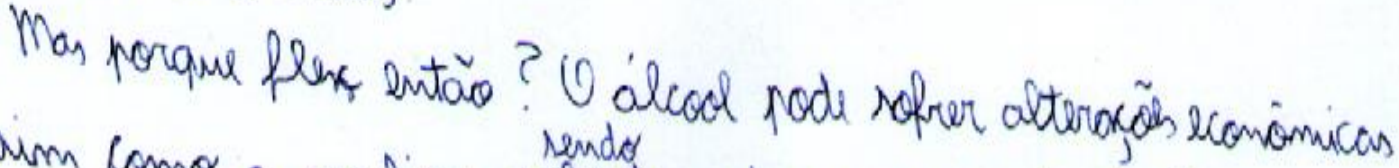
arrim cono a gavolina sendo mais ore merwos viavel. Porén a producío do álcool, por mais que a liburacià do $\mathrm{CO}_{2}$ é menor (ma queima do combritinel no carro), en agratóncicos, monocultura, condirós dos trabalhadores sào fatores megatives e de asto pleb ma deciráo. 
259

Texto 3

Weste caso um carro popular serra mais viavel, pois Além de ser econoumico no seu preco e no secs gastos.. Oflex (Alicol ou Gaso lina) seria uma otima etollta, pois pondo em usta 0 álcool. Alem de ser mais barato que a Gasolina, í. um combustivel renovavel trazendo nenos prejuizo ao ambiente.

Mas. se caso a dicool ficar muavel no. custo vocé tem a opcaö de por a gasolima apesar de náo sex Renocavel trai maior Rendimento para o motor pelo fato maive na combustáo comparado com O J'́cool. 
260

Texto 4

(20) Sollorio un cono flex e venons allod pars rente

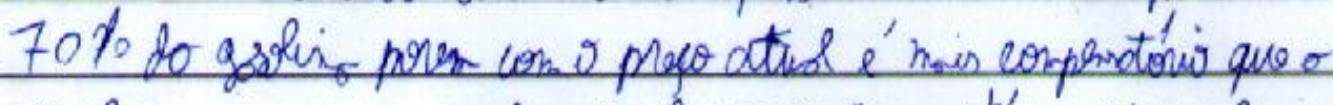

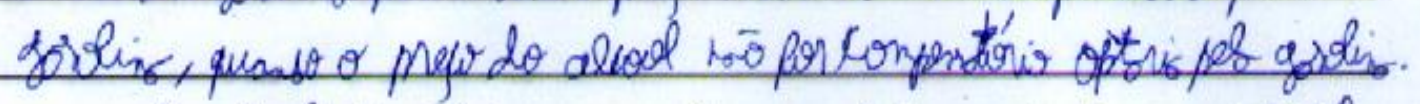

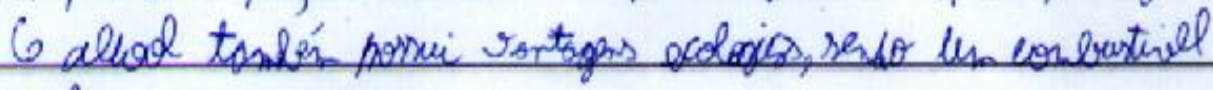
cenorgarel e polvinito nends, a gordino re trataro de lem

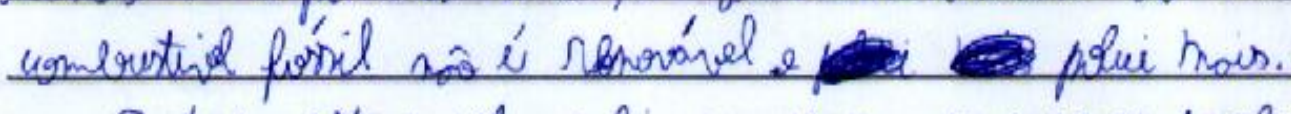

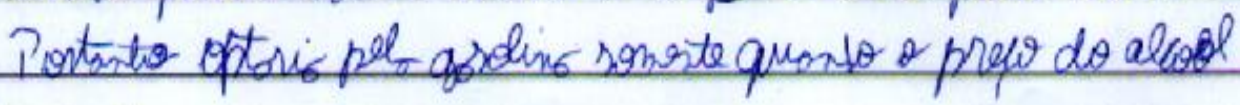
low Gempermose. 


\section{Texto 5}

\section{Tonsume Consiente}

To demandos de unergias no mei el wibanno cresce rignificamente, bempre há imovaciers na tecnoloja, novos produtos que dependem de energia elétricas et tombém no namo de automeveres anualmente se tem novos modelos a aumento do nével de ridostorna peosivel que cadas vez mais persocas comprem uma conducaio pró-

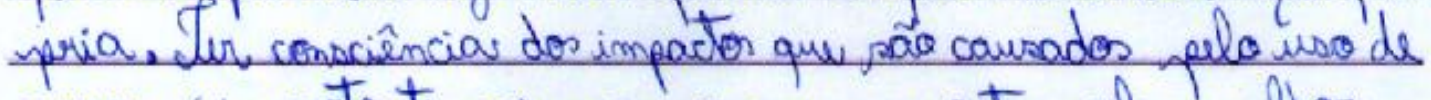
carros ú importante, pois assim consegue-oe optar pela melhor opröa de combustínel au sore consumido.

Jontes de optar por un combustroel fóssil aw remeróvel deoe-se levar um consideraräo diversos tipos de impactor, como a gavolina que libera grande quantidade de dioxido de carbano $\left(\mathrm{CO}_{2}\right)$, user gás catalisa o feito stula e éumovarrso finito quande

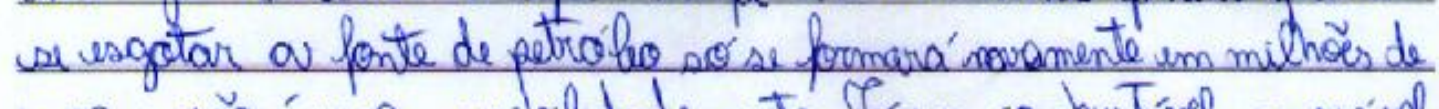
anos, enào í uma possibilidade certa. Já um combustrivel, renorável como o alcool causa também enivrão de $\mathrm{CO}_{2}$, mas em menor quantidade em relacáo as apolinar e acontece o procuso de fotonśntese per parte das canade-acúcar ciclando o ar. Impactos seciais tem mais destaque devido as condicoers do trabal ho, muitos trabalhadores nõo possui dirvitos trabalhistas e se võ um risco ac ter rontato com agrotóxicos que sá jogados na rapra e poden couvarvalergias graves a quem respiras ou tem qualquou autra contato com usases químicos.

Com tudo, impactos ambientais relacionados as ar merecem maior atencä́, pois préjudica a qualidade do ar na regiăo em que é emitido, impacton seciais embera sejam de grande umportóncias autran medidas devem ser tomadas parau regularizar as condicoes de trdealho, o que compremete as luovatividade dos latifundios apenas. 


\section{Texto 6}

Evescoltten'ta um cApro com motor flex, pois se o valor do alcool schir A GASOLINA VAI CompenSAR, e tambem 10 PARA lcONOMIZAR OMAXimo foSsivel.

\section{Texto 7}

Eur excolperia um corro Flex, per cauni da paras

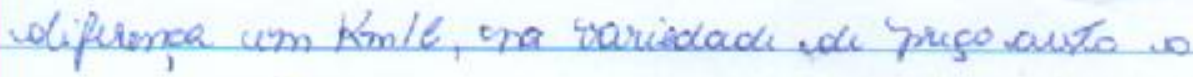
pundimantio de $70 \%$, mestmo tonow cenno prefuriencia o salked

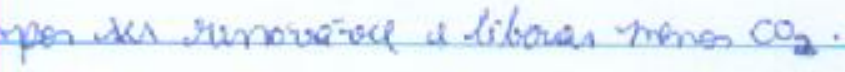

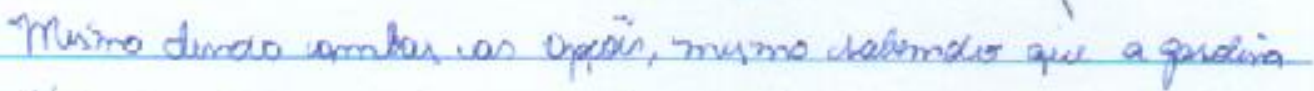

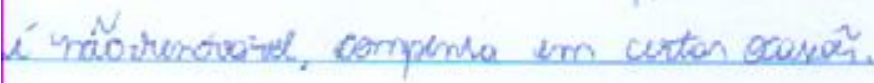




\section{Texto 8 - página 1}

Após assistir as aulas do modoló energia voltadas para o ćlalo da entalpia, for criado uma sizuacōo problema da escotha do melhor combustivel para um carro em Média de 30.000 mil reais

Fai analigado Zrés combustivers! gasolina, bodisel e álcool, mas como os carros sāo apenas gasolina, alcool ou flex a foco maior foi nesses dois combustiveis.

Em aula foi oriado uma Zabela da diferença dos mesmos

\begin{tabular}{|c|c|c|}
\hline $\begin{array}{l}\text { Alcod }(\text { zand }) \\
\left.C_{2} H_{5} O \mathrm{Ha}\right) \\
\Delta H=-1236 \mathrm{kf} / \mathrm{mol}\end{array}$ & $\begin{array}{l}\text { Gasolina Cootand } \\
C_{8} H_{18} \\
\Delta H=-5080 \mathrm{~kg} / \mathrm{mol}\end{array}$ & $\begin{array}{l}\text { Brodioel Coleato de métila) } \\
\mathrm{C}_{19} \mathrm{H}_{36} \mathrm{O}_{2} \\
\Delta H=-11.114 \mathrm{Kf} / \mathrm{Mol}\end{array}$ \\
\hline libera munos $\mathrm{CO}_{2}$ & libera mais $\mathrm{CO}_{2}$ & missāo de co \\
\hline Preacompétitivel & mpctivel & Preco alzo \\
\hline Renovavel & Moo renovavel & Renovarel \\
\hline & 9 & 11111 \\
\hline
\end{tabular}

De todos as compustívers discultidos em aula, ae fosse possivel optar um outra forma de combustivel, algo zāo puro quanto a àqua, algo que nāo devastasse fanto o meio ambiente, nethium desses combustiveis feria escolhido, mas como é necessário escother uma apacio analisando - custo beneficuo o carra flex, de acordo com as cálculos o álcool zem $70 \%$ da potencia da gasolina e se o valor do áloal for a ze $70 \%$ menor que o preco da gasolina cle $\varepsilon$ mais viável, entretanto se os valores form de acordo com a rentabilidade das combustivel a gasolina e mais vantasoja.

Porém se for analisado a emissāo de $\mathrm{CO}_{2}$ na atimosfera a partir da Revaluçāo Industrial oum a 0 ilizarāo dos combustiver's fóssus a etanol 2 a melhor saida

\section{arem}

Entretanto or analisoumas minunciosamente as desvanitagens da nonocultura e devastadora, pois é necessários grandes Zerrenas 


\section{Texto 8 - página 2}

- vários hequitares de floresta sēo desimados para essa monocultura extinguindo com a fauma e a flora daquele boal. Além disso, é ultilizado varios agrobóxicos para a combate de pragas, sendo coses compostos quimicos o mesmo usados em armas de guerra (a armas químicas).

Esses agratoxicos prefudicam a saúde das pessoas que as aplicam, além de contaminar a solo e possivicis lenecais freazicos, além do tovifero que pode ser atingido se ele nāo for muito profundo. As plantas tambem transportam ises agrotoxicas azé a mesa de milhares de pessoas e essas, por sua vez, padem sofrer consequen. cias for que seu efeŕtos sāo bioacumulativas

$$
\text { Enitao se for obserrado o menos prefudicial a vida }
$$

humana swos combustivers fosscis, pois a maveria das refinadoras petrolificas ficam no oceano. 


\section{Texto 9 - página 1}

Us criterios que devem ser onalisodos na hera. de compror e tós sos hoos autsmáve, vai de a rendiments do compentivel até so impocts ombientoin e sigciais que a mimo pecurá causon. A exalha entre a gobslima es alcogl é bem dificie, sá que anbos counoms dooss ao meis ombiente. Pedums esstä́s listor os prós $\alpha$ contios pora no fisale escalher quae deverá see $\theta$ combustival atex itilizaco.

If gasslina, um combustiul de grigem fosine, gós sofrer combustás libero muto mangxido Ou corlosms que rquande liberado em grosous quontido-

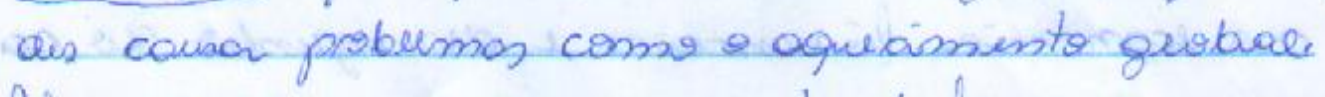

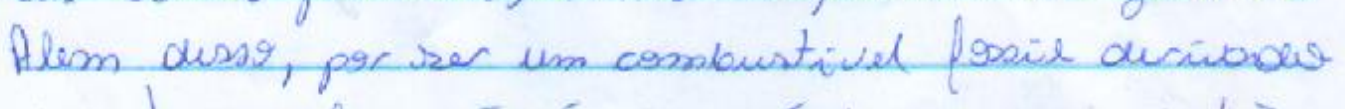

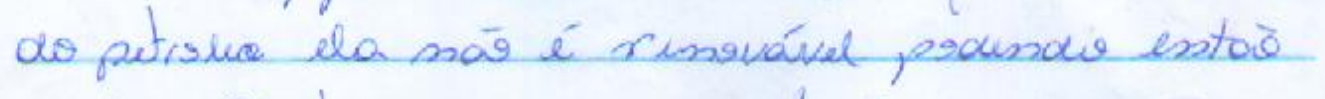
cabor. contude, a rendiments que a gosveima. ponmi é bastonte atrative podendo asims ser um fotar duasive na savilua da mema. renguorel, libera praticomenti a mesma guonti-

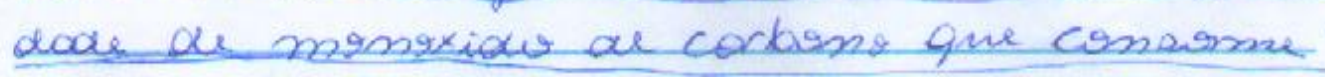

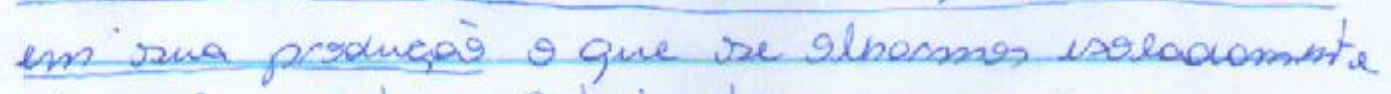
émuts positive. Entretomts a proaugà al alcogl vó é posivel a portir el momecultrures e lé dí que esta e pobaboua mair perbensa. dese combustivel pis sompocts ombientoin e sociois uniass a uma gertas pelitíca precóna dixam em auvionas se ele reabsanste lé a melner epcóo. Is empoctos ambientain vás asou - emprbicimento do solo até presuigos 2 bisdinersidode locoli pora $\theta$ controh al progas. 
266

Texto 9 - página 2

l mulas renaimento da producāo é ubtilizada uma gronde quantiacol de pesticiaos e autros produtor quimior que pgi labta de cautula ocobam cousando acmos à soude himmona.

ienas em vista treos esses fatos veltamss a Qurstä unicial, qual combuntivel utilizor? Infelizmmate máo há uma resposta certa, etomberm nós há um mulhor exim um mensos Pigr, Eu optocia por um outomsvel / lux, pois com ele consuguitia loger um rodizio e

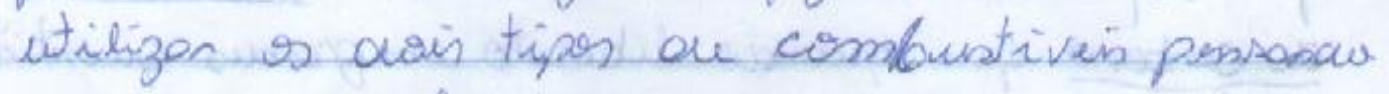
na economia fünonccira e desempentwe do corro. 
Texto 10

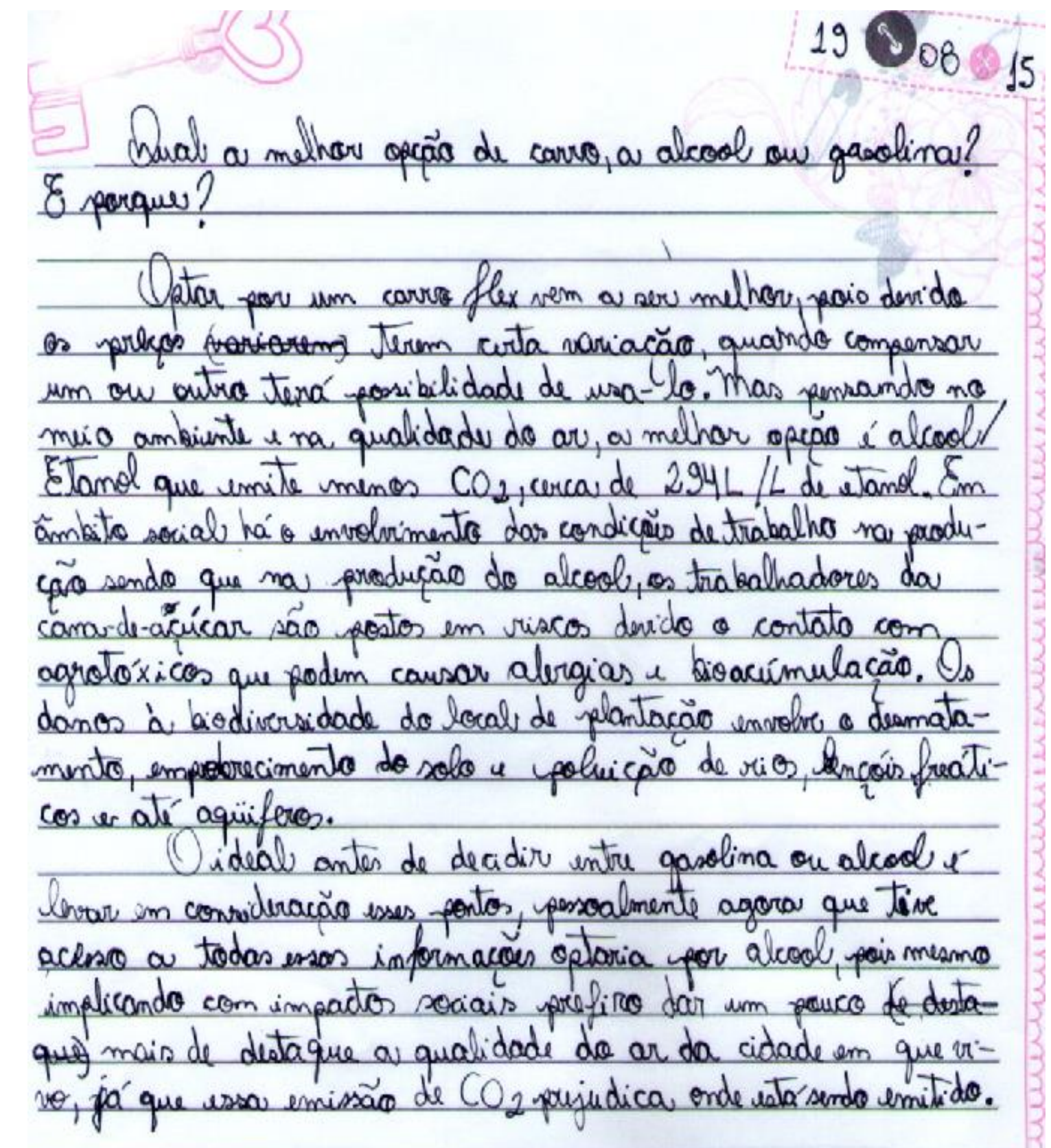




\section{Texto 11}

Eu eredheria o carre 1.0 flex por ver mais económico. Abo foce questão de velocidade au arranque, mas sim de gastar menos e doter o melhor desempenho. Optaria ainda per usar $\theta$ álcool, primeiramente pelo fatto de custar menes per litre e ferecer con isso desempenho próxime as de gastima; em segunde instion Ciar, pelo pato de ser um combustíbl remavábl, opresentendo biomasta oomo matéria-prima ef ainde, por apresentar uma baixa emistár de ás. carbônico ( $\mathrm{CO}$ ) - quande cemparado a gosdina es biodiesel. Entretarto, a preduéco en larog escala do etand demanda aumento de monecultura, que í esdejicamonte pretenivel. 1. Na situasāos do prece do álcol uetrapassar a marca de 69\% do preco da gasdina, esta parsa a ser ecoriomitamente mais interessante. E 'é neste momento que a carro plex passa a ser interessente também. 
269

Texto 12

Um conve flex, deneda in reviacoor

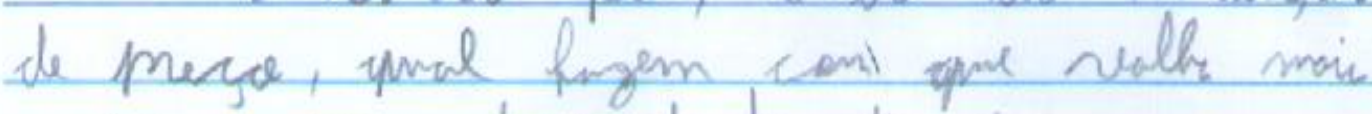
as pen un dependendo dor precer.

Par um lado a alcoal Gern' una mana

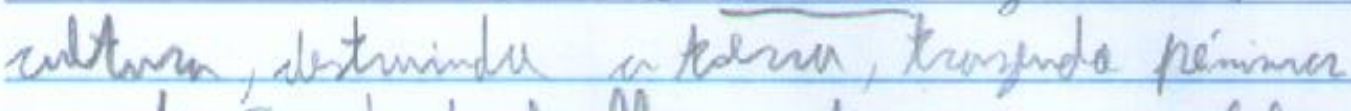

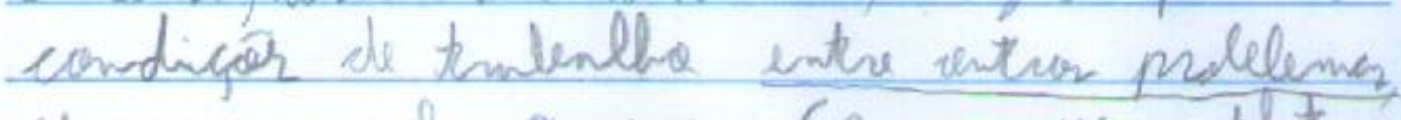

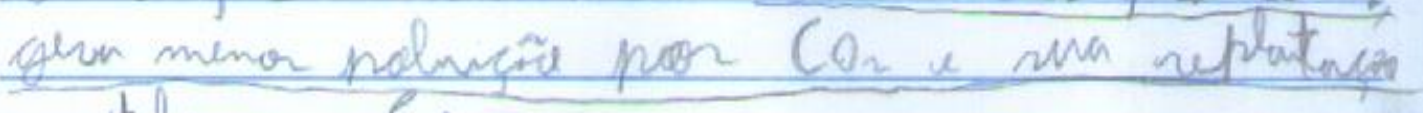
entilina ic CO

In a revolina gern pahurgato movitina,

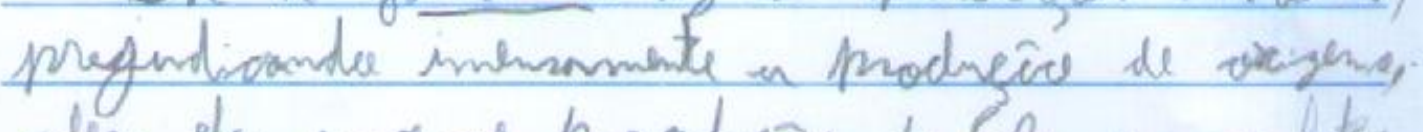

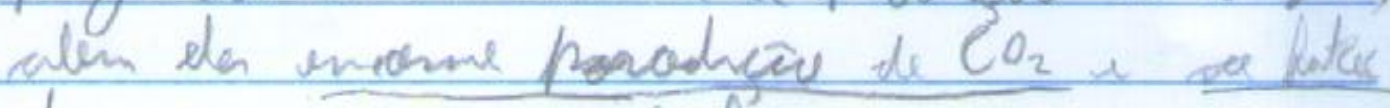
de noto ser rementivel.

Comber de crande destrmiciod nateral, a escolbr fece comente ma reiñod ecomanuca. 


\section{Texto 13}

Cotar pov álcool gur ganolima nas ímar es

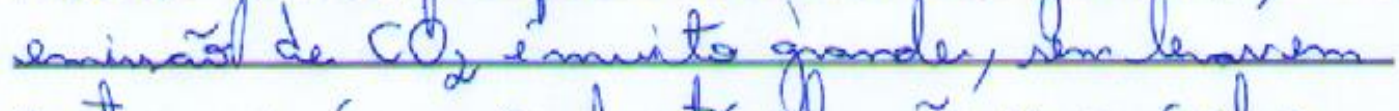
conta que é un combustínel mär semoncínel, wh seja, uma dias poderá chegar a faltar. Porén a

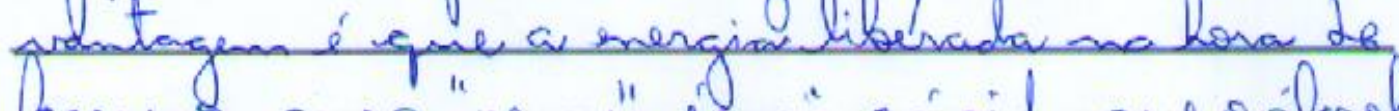
Laver is canro "pegan" imair rápida que ocícsol. mair diffeil de un dia chegar ar faltax, equare

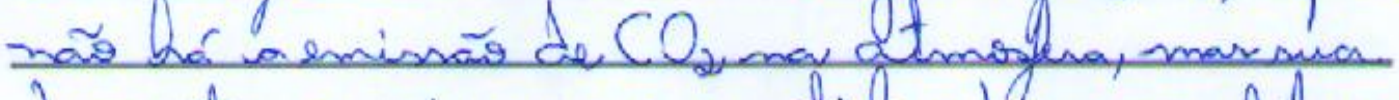

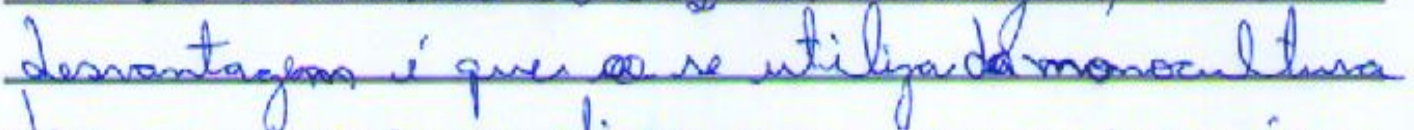
Lecana, suro quer diger, que he una sama ára

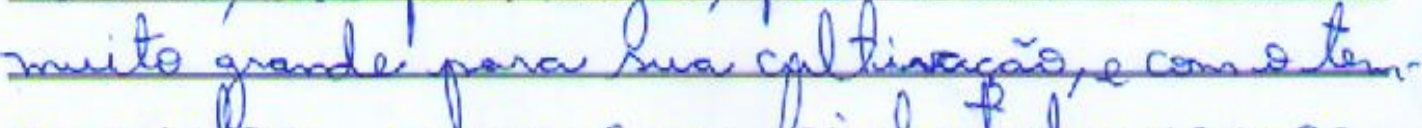

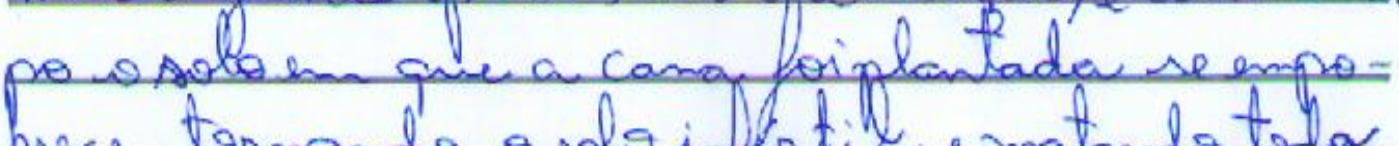
brece tormando o sols infertil, e matando todo ar mameira de ardareinte te ali

Whar,conos se ípreciso de un dos ditincombus. tirveir citador parar s sarro ander, ew optariarpulo

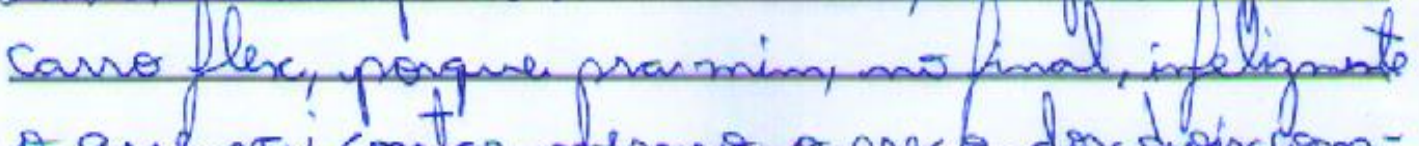

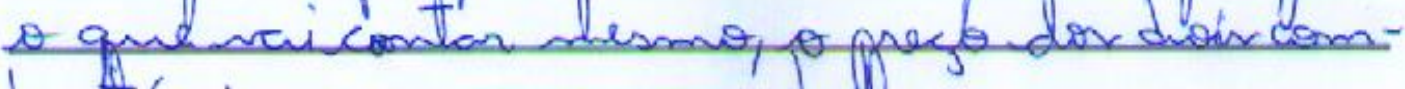
bustineir parar onem bolser. 
271

Texto 14

tonto alcool quanto a garolina tin sens pontos neag. tires, o allool pos excemplo libero menos $\mathrm{CO}_{2}$ ane a gaso Lima, mas a monocultura para retinada do atcool prejicicica solo, tambem alstando a fauna i a flow. O lado pasitino da illeal ser remasaivel? Dempre uri ter, mas, cado vez maix - solo, entre autres, rerio mais prefidicades. I garolina li. lerra muito mais $\mathrm{CO}_{2}$ que aletea na tamperatura pele gram, de quantidode jä eccistente no an. acumulition da C sasacha de un Flex seria equilitorada tanto pen esses pres i contras mas tamprim pela variacio de proco a rendi. mento das dois combrestiveris 


\section{ANEXOS}




\section{ANEXO A Termo de autorização de uso de imagem e voz (para menores de idade)}

$\mathrm{Eu}$, , portador(a) da carteira de identidade, $\mathrm{RG}, \mathrm{n}^{\mathrm{o}} \longrightarrow$ expedida pelo órgão expedidor_, inscrito(a) no CPF sob o $\mathrm{n}^{\mathrm{o}}$ , residente $\mathrm{e}$ domiciliado(a) no endereço responsável por portador(a) da carteira de identidade, $\mathrm{RG}, \mathrm{n}^{\mathrm{o}}$ , expedida pelo órgão expedidor_ inscrito(a) no CPF sob o $\mathrm{n}^{\circ}$ , o(a) autorizo, de forma expressa, a ceder o uso de sua imagem e do som de sua voz, sem qualquer ônus, para fins de pesquisa de doutorado em Ensino de Ciências/Ensino de Química da doutoranda Beatriz Vivian Schneider-Felicio, portadora do RG, $\mathrm{n}^{\circ}$ 35.058.124-1, CPF n 319.288.788-57, domiciliada na Rua Castro Alves, 402, Vila Tibério, Ribeirão Preto - SP, aluna do Programa de Pós Graduação Interunidades em Ensino de Ciências da Universidade de São Paulo, CNPJ: 63025530/006-19.

Ribeirão Preto,__de de 2015. 


\section{ANEXO B Termo de autorização de uso de imagem e voz (para maiores de idade)}

$\mathrm{Eu}$, , portador(a) da

carteira de identidade, RG, $\mathrm{n}^{\mathrm{o}} \longrightarrow$ expedida pelo órgão expedidor__ inscrito(a) no CPF sob o $\mathrm{n}^{\mathrm{o}}$ _ residente e domiciliado(a) no endereço autorizo, de forma expressa, o uso de minha imagem e do som da minha voz, sem qualquer ônus, para fins de pesquisa de doutorado em Ensino de Ciências/Ensino de Química da doutoranda Beatriz Vivian Schneider-Felicio, portadora do RG, $\mathrm{n}^{\mathrm{o}}$ 35.058.124-1, CPF no 319.288.788-57, domiciliada na Rua Castro Alves, 402, Vila Tibério, Ribeirão Preto - SP, aluna do Programa de Pós Graduação Interunidades em Ensino de Ciências da Universidade de São Paulo, CNPJ: 63025530/006-19.

Ribeirão Preto, de de 2015. 